

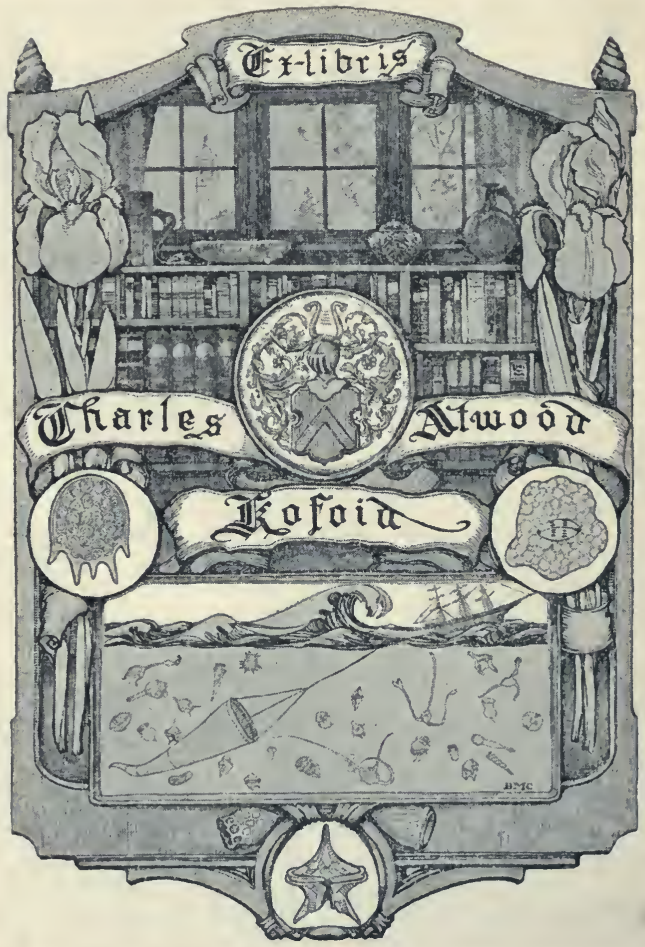




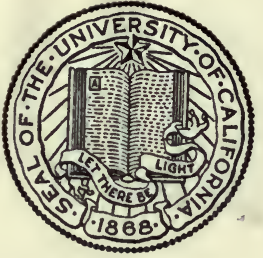

THE LIBRARY

$\mathrm{OF}$

THE UNIVERSITY

OF CALIFORNIA

PRESENTED BY

PROF.CHARLES A. KOFOID AND

MRS. PRUDENCE W. KOFOID 



\section{THE BOOK OF FISH AND FISHING}



Digitized by the Internet Archive in 2007 with funding from Microsoft Corporation 


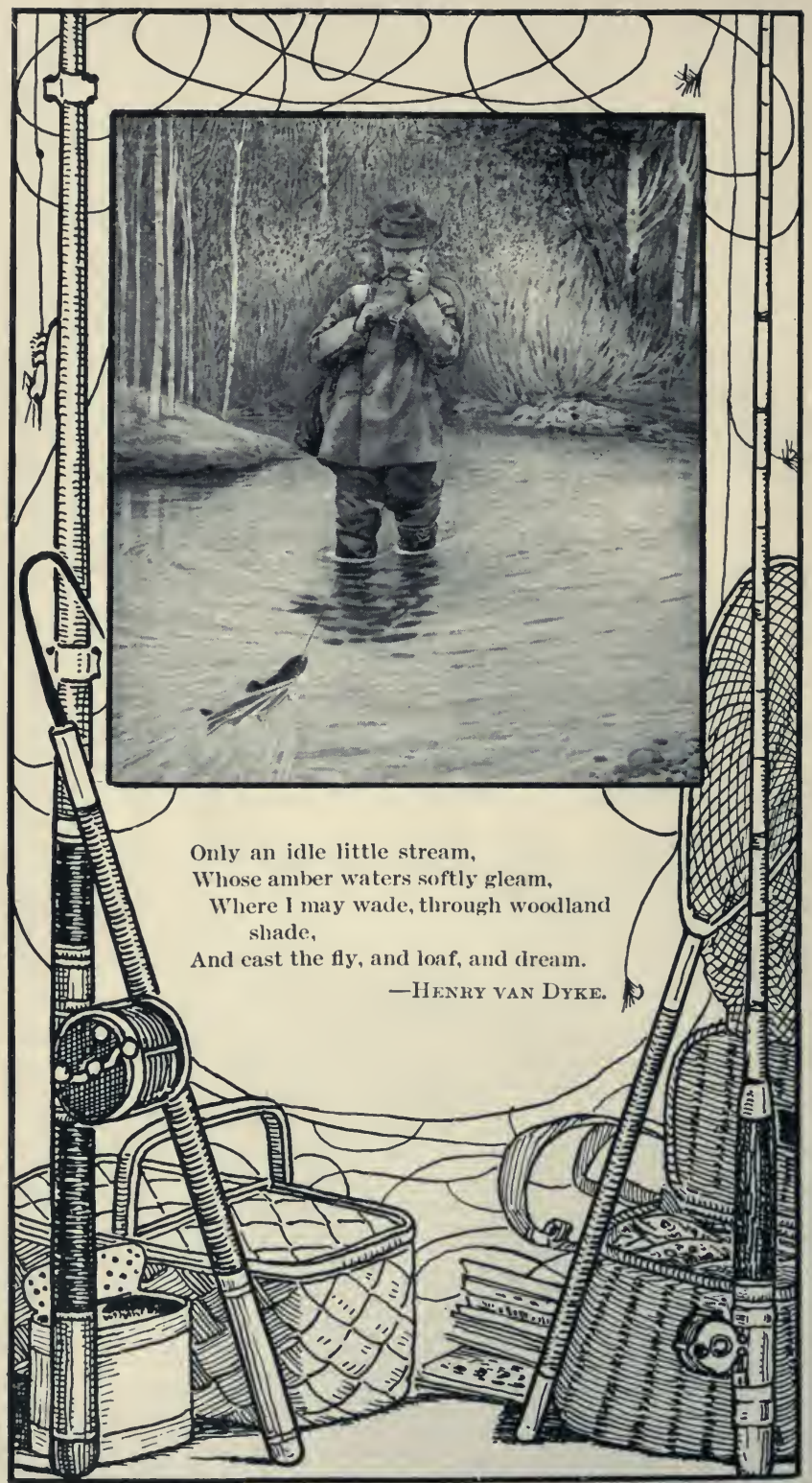




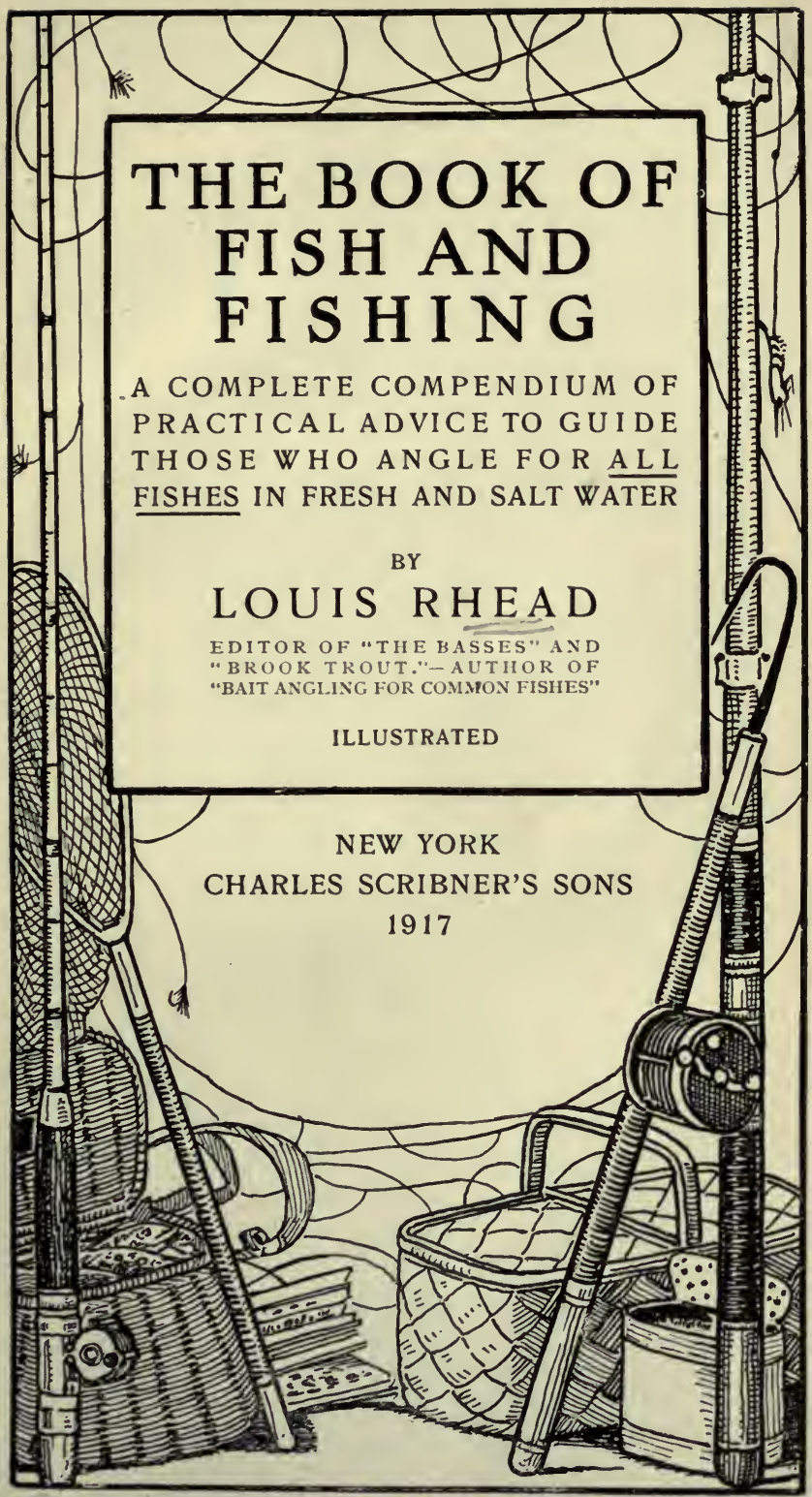


COPYRIGHT, 1908, BY CHARLES SCRIBNER'S SONS

Published June, 1908

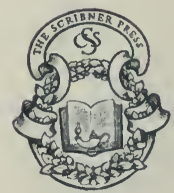




\section{TO MY WIFE-}

NO FISHER-

\section{BUT FOR WHOSE ASSISTANCE}

I COULD NOT BE ONE 



\section{$R 48$ \\ 1908}

\section{PREFACE}

The object of this book is to inform anglers about every kind of fresh-water and especially marine fish-"much in little." Those fish not angled for are left out, and scientific names and descriptions are not considered. Of the thousands of fish in American waters, $I$ have selected only those best known for gameness and economic value, so that the veriest tyro can be informed about angling methods and any equipment he should need without trouble, time, and expense in searching other works. First and last, I have tried to make an all-round pocket guide-an encyclopædia of facts - the easiest and best ways, how to catch, where to go, and how to get the best sport.

To avoid monotonous repetition, the writer deemed it wise to plan the book under sub-divided headings and to combine the various fish in groups and collate the methods of taking them so that they can be seen at a glance. Complete information concerning each fish is not, therefore, confined to a single chapter, but occurs under various headings, as shown in the Contents, page xi.

The writer has, all his life, been much attached to the sport of angling, and circumstances vii 


\section{Preface}

have permitted him to indulge in that passion to a greater extent and over a wider field than either time or opportunity would probably have allowed most anglers. He has taken every game fish that swims, from the southern borders of Labrador down to the Dry 'Tortugas, as well as in many of the great inland seas. During the last twentyfive years he has made careful and painstaking studies of the most approved methods to lure, and also of the habits of fishes.

I believe we are on the verge of a revolution, both as to breeding and stocking, not only by the various States, but by private individuals who will take up fish culture as a commercial enterprise; while more advanced methods of taking fishes will be employed by means of better tackle and an intelligent use of it.

It is over fifty years since the "Jock Scott" and "silver doctor" salmon flies were invented. Nothing in flies has been made since to equal them. On the other hand, marvellous strides have been made during the last twenty-five years in artificial lures, mostly remarkable from the fact that they are rarely imitations of living bait.

Heretofore angling books have been almost entirely devoted to fresh-water fishes; in this volume the vast army of salt-water anglers may have information in compact form about their popular favorites.

For information concerning the various game fishes I have consulted and quoted from the works of the following distinguished authorities: viii 


\section{Preface}

Charles F. Holder ("Fishing on the Pacific Coast"), the late Dean Sage ("Atlantic Salmon"), the late Wm. C. Harris ("Bass and Trout"), Dr. Tarleton H. Bean ("Striped Bass," "Hatching," and numerous other subjects), H. Cholmondeley Pennell ("Trout and Salmon"), W. C. Stewart ("Worming for Trout"), John Bickerdyke, Major Traherne, Frederick M. Halford, Henry R. Francis, Dr. Brown Goode, Charles Hallock, Thaddeus Norris, Frank Forrester, Genio Scott, and others.

For the mode of capture, both for fresh-water and marine fishes, I have used my own experience and practice, except in case of the tuna and black sea-bass of the Pacific Coast.

In the art of angling there is much diversity of opinion as to what is best, both in tackle and methods. In such cases, I have taken a middle course, avoiding dogmatic rules, laying down no rock-bound law and merely expressing the opinion of what I consider best, whether in my own experience or that of others.

The author wishes to acknowledge his indebtedness to the United States Bureau of Fisheries for permission to use numerous cuts in this volume.

Louis Rhead.

Flatbush, L. I. 



\section{CONTENTS}

I. Popular Fresh-Water Game Fish ..

Salmon - Mascalonge - Pike - Black Bass-Grayling-Trout-Charr-trout.

II. Popular Salt-Water Game Fish . Leaping Tuna - Tarpon - Black SeaBass - Yellow Tail - Weakfish of the Atlantic and Pacific - Striped Bass Blue-fish - Bonito-Albacore - Channel Bass - Sheepshead.

III. Popular Bottom Fresh-Water Fish .

Pike Perch - Dace - Chub - Carp Sunfish - Perch - Eels - Catfish.

IV. Popular Bottom Sea Fish - . 98

Sea-Bass - Tautog or Blackfish - Kingfish - Plaice - Flounder - Lafayette Porgy - Smelts - Cod - Tomcod.

V. Where to Get Them - 119

General distribution-List of placesGood waters for Salmon, Bass and Trout -Mascalonge.

Best places for salt-water fish.

VI. How to Get Them .

SALMoN: With the fly-Killing fliesWorking and casting from a canoe-With live bait-Trolling-Prawn methodsThe worm.

Mascalonge and PIKe: Still-fishing in rivers and lakes-Gang hooks-Baitcasting-Trolling.

PIKe AND PICKerel: Trolling-Skittering-Still-fishing.

BLACK BAss: With the fly-Small fies in 


\section{Contents}

CHAPTER

PAGE

rivers - Weather conditions - Minnows and how to hook them-Various live baits - The best artificial lures.

Trout: With the fly-Brook and river fishing-Dry fly-fishing-Casting the fly -Live bait-fishing - With worms.

VII. When to Get Them

Time of DAY: Early morning-Mid-day -Sunset-Night.

Best season: Fish caught early-Fish caught late.

OPEN AND CLOSED SEAson: Why closed season is required.

Best KIND OF WEATHER: Windy dayWet day-Dry day.

VIII. With What to Get Them

RoDs: Casting power-Solid and bamboo-Steel rods-Fly rod and bait rod.

TACKLE: Reels-Lines-Gut.

Hooks: Names-Bend-Size.

EQUIPMENT: Dress-Wading-boots and stockings-Landing-nets-Fishing pocket-book-Sundries.

WOMEN WHO FISH.

IX. How to Play and How to Land Them

Way to handle rod-Way to handle line and reel-How to use net-Gaffing.

X. The Right Way to Keep Fish Fresh 283 In the creel-Icing them-At the end of day's trip-How to pack them.

XI. How to Cook Them

292

Cleaning fish-Camp cookery-Serving fish.

XII. Simple Hatchery for Trout

Care of fry-Location required-The kind of water-Stocking brooks-Feeding. 


\section{ILLUSTRATIONS}

Popular Fresh-Water Game Fish . - 1 . 4 Atlantic Salmon-Pacific Salmon-Lake Trout-Brown Trout.

Popular Fresh-Water Game Fish 13

Speckled Trout-Rainbow Trout-Malma (Dolly Varden) Trout-Tahoe Trout.

Popular Salt-Water Game Fish

Tarpon - Tuna - Black Grouper or Jew-fish-Bonito.

Popular Salt-Water Game Fish 50 Blue-fish - Weakfish - Spotted Weakfish-Spanish Mackerel.

Popular Salt-Water Game Fish 60 Striped Bass-Drum-Mackerel-Shad.

Popular Bottom Fresh-Water Fish . 84

Common Carp-White Bass-White Catfish-Perch.

Popular Bottom Sea Fish Sheepshead - Porgy - Tautog.

Popular Bottom Sea Fish Fluke - Flounder - Sea-Bass-Kingfish.

Popular Bottom Sea Fish

Cod-Spot-Tomcod-Sea Eel. xiii 


\section{Illustrations}

FACING

PAGE

Popular Fresh-Water Game Fish

128

Small-mouth Bass-Large-mouth Bass-

Rock Bass-Grayling.

Popular Fresh-Water Game Fish 158

Mascalonge-Pike-Pickerel-Wall-eye.

Popular Bottom Fresh-Water Fish . . . 204 Sunapee Trout-Loch Leven TroutLeather Carp-Sunfish.

Maps

Distribution of fresh-water fish on North American Continent . . . . 127

Distribution of salt-water fish on the Atlantic, Pacific and Gulf Coasts . . 141

Charts

Showing the habitat, tackle, time of day, bait and season of:

Popular salt-water fish . . . 226-227

Popular fresh-water fish . . . 228-229

There are many additional illustrations and diagrams in the text, drawn by the author. 


\section{THE BOOK OF FISH AND FISHING}





\section{CHAPTER I}

\section{Popular Fresh=Water Game Fish}

\section{SALMON}

First, among game fishes, the salmon is supreme, not only in its gallant resistance and fighting qualities, but, perhaps, in its value to the human race as a highly prized and nutritious food. Its beautiful and shapely form,

The Salmon Family especially when first taken from the water (if a newly run fish), gives its captor the greatest pleasure. With pardonable pride, as he beholds its shiny, silvery sides, he exclaims, every time he lands one, "What a noble and brave antagonist!"

The two most important species are the quinnat salmon of the Pacific, and the Atlantic salmon -the latter inhabiting the North Atlantic, and ascending many of the rivers for the purpose of reproduction. The most southern river in which Atlantic specimens have been obtained, is the PotoSalmon mac. It occurs in small numbers in the Delaware and in the Hudson, but in these three rivers its presence is the result of artificial introduction. Its occurrence in Lake Cham- 


\section{Fish and Fishing}

plain, the St. Lawrence River, and tributaries of Lake Ontario, is due also to modern fish culture.

The State of Maine has many ideal salmon rivers, and a few of these fish are caught; but a thousand times less than should be, for conditions show a most discouraging state of affairs. The Kennebec River, which is an ideal salmon stream, was robbed of fish by the building of a dam at Augusta. The Penobscot is fast going down under the illegal fishing and pollution of its water from various factories near its mouth. The St. Croix (partly in Canada) though not so bad, is growing worse. The Connecticut River has been stocked several times, but when the salmon returned to it, they were all caught by the netters at the mouth, in direct violation of the law. So the salmon angler finds that the British possessions in North America undoubtedly afford the greatest field for fishing in the future.

Beginning at the south in the River St. Lawrence, and farther east in Nova Scotia, which has a number of small but fair streams, and following Localities the north shore of the river and of the Gulf of St. Lawrence up to the Strait of Belle Isle, there are scores of tributary rivers abounding in salmon. The Miramiche and Nepisiguit are probably the best of those south of the Restigouche in the Bay of Chaleurs. This river is a large and beautiful stream, running back between the Province of Quebec and New Brunswick, a distance of over two hundred miles, with four large tributaries, the Metapedia, the Upsal- 


\section{Popular Fresh=Water Game Fish}

quitch, the Patapedia, and the Kedgwick. It flows in a generally north-east direction and has in its entire course no falls or rapids which a canoe cannot surmount.

The Restigouche Salmon Club has purchased a large portion of the best angling on the river, and the rod fishing yields about twelve hundred salmon and grilse yearly, which is far below its probable production if netting were not so prevalent. For this reason, the average size of the fish is diminishing. On the other side of the Bay of Chaleurs is the Grand Bonaventure and the famous Grand Cascapedia-both full of large fish, some being taken of over fifty pounds; but the average is probably twenty-five pounds.

Only eight fish per day are allowed to be taken by one rod. The St. Anne des Monts is another good river of the north shore, where fish run large. The Grand, Dartmouth, and others in Atlantic the Gaspé district are good, and the fish
Salmon are of fair average size, with some large ones. The Godbout, on the St. Lawrence, is a remarkable river-a catch of fifteen to twenty salmon to one rod in a day is not unusual. The fish are small in the Godbout (but so is the river, which is very broken), and fished almost, if not entirely, from the shore. In 1901, three rods took in twelve days two hundred and seventeen salmon.

The Moisie and the Mingan, farther down, are good, and the fish large, averaging over twentytwo pounds. The Natashquan is a good-sized 


\section{Fish and Fishing}

stream full of small fish, from eight to twelve pounds. This river marks about the eastern limit of the rivers which are at all well known. The Esquimaux River, in the Strait of Belle Isle, is probably the greatest known salmon river. It is very large and long, without heavy falls to prevent the salmon from ascending to its upper waters.

The vast, practically unexplored region north of the Strait of Belle Isle extending up to Davis Strait and to the West-including a thousand miles of shore line of Hudson Bay-is undoubtedly full of salmon rivers, where a fly has never been cast. There are vague rumors of enormous quantities of salmon in the rivers just north of the Strait of Belle Isle-the Hamilton being especially spoken of.

At the present rate of destruction, those wanting good salmon fishing are quite likely to have to look as far as these remote regions for it, in the next twenty-five years. What good fishing there is close at hand is hard to get and very expensive.

Of the Pacific salmons, the quinnat salmon is the largest and most prized. It is known under various names, such as the chinook, tyee, king salmon, Columbia River, and Sacramento Salmon. It ranges from Monterey, California, to Alaska and eastern Asia, ascending rivers in some cases fifteen hundred miles, or farther, from the sea. It is the largest of the salmon family-individuals weighing one hundred pounds, and upward of five feet in length, being on record, taken from the 



\section{Popular Fresh=Water Game Fish}

Yukon and other rivers. The flesh of this salmon is paler than the red salmon, but it is superior in flavor to all others and very valuable for canning, salting, and smoking.

The quinnat is first seen in Monterey Bay as early as January, and many are caught by anglers for several months while the fish are frequenting this rendezvous and becoming fat on small fish preparatory to entering the Golden Gate and beginning their long and last journey up the Sacramento, which stream many have entered by February.

In March this fish is seen in the Columbia, but not until May does it become abundant. It seeks the shores of southern Alaska in May, and probably reaches the Yukon the latter part of June. The runs continue for four to six months in southern waters, while in northern Alaska the running season is very short, not exceeding six weeks.

The other species of the Pacific salmons-but of lesser value-are the blue-back salmon, humpback, silver, dog, and the steelhead salmon. The latter, while in reality a trout, is popularly regarded as a salmon. It feeds freely in fresh water and does not die in the streams after spawning, but returns to the sea. It is a general favorite on account of its size, beauty, gameness, and food value, and will be mentioned with the trout.

The ouananiche is a fierce-fighting, fresh water understudy of the Atlantic salmon, often wrongfully termed landlocked. Its home is in Lake St. John, Province of Quebec, and at the outlet 


\section{Fish and Fishing}

which forms the River Saguenay; it also thrives in many of the rivers that flow into the Gulf of St. Lawrence and in the rivers of Labrador.

This fish loves rapid and turbulent waters, and because of the life it leads, it is beyond doubt, for its size, the most vigorous and athletic fish that inhabits northern waters. It will leap from the water seven or eight times after being hooked, and with the greatest rapidity rush down below one hundred feet. A fish weighing three to four pounds will make a fight lasting from ten to fifteen minutes.

Its food consists mostly of flies, which it picks from out of the foam that lies in blankets, sometimes forty to sixty feet in extent, washed down by the swirling flood moving round and round below the rapids. In such pools the ouananiche is fished for with fine but strong tackle, and nothing but flies are used.

In the fall it takes a small minnow, but the cream of the fishing is from June 15th to July 15th. At the Grande Décharge, it is fished for from a canoe handled by two Canadian guides, or, on some of the small islands that rise up steep from the water, the angler casts his flies from the rocks above and the guide nets them. Twenty fish is the limit on one rod per day, and they weigh from four to seven pounds, the average size being two pounds, though specimens have been caught up to nine pounds.

The Sebago salmon, of Maine, is a similar freshwater species and is found in the lake of that name. 


\section{Popular Fresh=Water Game Fish}

It attains a weight of fifteen pounds but averages from eight to ten pounds. It does not manifest the fighting qualities of the ouananiche owing to the quiet waters it inhabits.

\section{MASCALONGE AND PIKE}

A peculiar trait of the pike family is to lie in wait for its prey, partly hidden by weeds or logs and shelving rocks. They are the most voracious fish that inhabit our inland waters.

Chief among them is the famous mascalonge, which is a game fish of high rank, and its large size makes it a great prize, as it reaches a length of seven and a half feet and attains a maximum weight of about one hundred pounds.

There are two species-the spotted and unspotted mascalonge-the former being abundant in the Great Lakes, the St. Lawrence, and widely distributed through southern Canada. The unspotted or Chautauqua mascalonge is confined to the lake of that name, and a few localities in the Ohio Valley.

It is now being successfully propagated by artificial cultivation and, no doubt, in the near future will be more widely distributed. It grows to a weight of fifty pounds and though not so large as the spotted species, in my opinion (and I have caught both), it is in every way a superior fish, both in its gallant fighting and beautiful coat, as well as for its edible qualities. This opinion exactly coincides with that of Dr. Tarleton H. Bean, to 


\section{Fish and Fishing}

whom anglers are much indebted for his intelligent planting of the fish raised at the hatchery at Bemus Point.

Both species devour every living creature that comes in sight, preying upon all other fishes, frogs and amphibians generally, ducklings and other small aquatic birds and mammals, as well as the young of their own kind.

The pike family are most remarkable for the large size of the head which is flattened and the lower jaw which projects. They have a terrible array of sharp teeth of assorted sizes, and on the edge of each side of the lower jaw are several long, bayonet-shaped fangs-in the larger fish nearly an inch long, some of them curved inward like the tusks of a boar.

It is solitary in its habits, lying concealed among the water plants and reeds at the edges of the streams or channels where other fish fare likely to pass by, or standing motionless beside shelving rocks or banks, in clear lakes, whence it darts upon any luckless fish that approaches its lair. With mouth tightly closed, it springs like a thunder-bolt till very near its victim; Feed it brings them together with a sudden snap, sometimes cutting its prey into two pieces, always taking the fish or lure sideways. Then it slowly returns to its hiding-place to gorge. There is no special time when they take their food; they are always feeding. The number of fishes swallowed and wounded by mascalonge during a single 


\section{Popular Fresh=Water Game Fish}

summer is almost incredible, most of them fish large and old enough to reproduce their kind.

The great northern pike is of exactly the same disposition, and so, in a lesser degree, is the pickerel, except that neither the pike nor pickerel has Pike been known to rise above the surface of the water after being hooked. All the species are wandering, savage tyrants, preferring to lie in solitary places, waiting, ever ready to pounce on their victim.

The range of the pike in America is from Lake Champlain, the Great Lake region, and
the upper Mississippi River, north to
Alaska. In many of the large lakes of northern Alaska. In many of the large lakes of northern New York, especially Lake George, pike are common. They also grow to a large size Size and Weight at the outlet of Lake St. John and the Saguenay River; specimens up to forty pounds are recorded there, at times.

All over Canada, especially in the tributaries of the St. John, this fish is caught in large quantities in nets, as well as on lines. Its fight, when captured, is not so prolonged or persistent as the mascalonge. It resorts to no devices to elude capture, but makes fierce lunges in long straight lines, sometimes on the surface, at others down below; but a heavy fish of twenty pounds requires considerable strength of arm and tackle to hold it in subjection. It has the same habits in its food, in regard to place and time of feeding, as the mascalonge.

In its general form, the pickerel resembles a 


\section{Fish and Fishing}

small pike. Though it is more slender, it grows sometimes to two feet in length, and weighs up Pickerel to seven or eight pounds, though its usual weight is three or four pounds. Its range extends from Maine along the coastwise streams, to Florida and Louisiana. It is so comLocality mon that it is difficult to say where it is not found. In all the lakes and ponds of Central Michigan and New York it is fished for by a host of admiring anglers. To stand up in a boat that is properly handled and throw a trolling spoon along the borders of the lily-pads where the pickerel hide is considered excellent sport. In the crystal clear water, the whirling, glittering spoon is in sight every moment, and the fish may be seen when it rushes straight at the lure. Wherever the pickerel is placed, it at once makes a home, breeding rapidly, soon becoming abundant, and growing in size according to the amount of food at hand. What it lacks in game qualities is made up in the quantities by which it is taken, and thousands of anglers are content and take pleasure in such fishing of a common Habits kind. On a still smaller scale, its habits of the pike. It is a deadly enemy to the young of brook trout, dace, chub, and various minnows.

\section{BLACK BASS}

The black bass enjoys, without doubt, the widest popularity of all the game fish of North 


\section{Popular Fresh=Water Game Fish}

America. The trout are known to a much smaller number of people for the reason that bass are abundant in the most densely populated portions of the United States, while the human neighbors of the trout are comparatively few. There are two species so very much alike that there is practically but one point of difference-the size of the mouth-and their habits are identical. The smallmouthed black bass is a fish of the East and North from western New Hampshire to Manitoba and southward to South Carolina and the northern Gulf States to Arkansas. The large-mouthed ranges from Manitoba southward to the Gulf States and spreads through the latter to Texas and Florida. It abounds in all the rivers of the Southern States. So widely have both species been distributed within the last few years that it is difficult to mention a section of North America where this brace of splendid game fish may not be found abundant.

Its popularity may be inferred by the remarkable number and variety of 4 names it goes under. The large-mouthed is known in the Lake region as the "Oswego bass," in Kentucky it is called "jumper," in Indiana "moss bass," in the Southern States "trout," though in North Carolina it is called "chub," in Alabama "mountain trout." Many other names are applied to one or both species. One of the pet names among anglers is "bronze-backer." Both species are born fighters on the line, as well as in the water, among their own and other kinds. For its size, it is the most 


\section{Fish and Fishing}

active leaper, barring the ouananiche, of all our game fish.

In form and color it is about the ugliest game fish, the caudal, rear dorsal, and anal fins being out of proportion to what otherwise would be a shapely form; nevertheless, the black bass fills a most important space in the angler's sport, for if you hook even a two-pound bass in a running stream, you are at once aware you have engaged a fish and a jolly "kicker" at that. Just as soon as it feels the barb, out of the water it shoots, giving the rod, reel, and angler such a lively time that one cannot but admire its pluck even unto the moment you rap it on the head.

Even in quiet lakes, its leaps and surges are admirable, where otherwise most trout are tame. Yet, with all this, in fishing streams where both are common, when I hook a bass I always regret it is not a trout. Some writers-one especiallyhave made a sort of demi-god of the bass; but few anglers who have opportunities to fish for salmon-both sea and landlocked, as well as trout, even brook trout-will leave them for the bass.

The reason, I suppose, is that bass are not always willing to take a fly, and one is more sure to get them on live bait. The ordinary size of an adult fish is two to three pounds, though specimens have been taken up to eight pounds. In Florida, the large-mouthed grows larger. Eight-pounders are not unusual in the St. Johns River; specimens have been recorded up to twenty pounds, caught in the lake at Gainesville, Florida. The bass do 


\section{Popular Fresh=Water Game Fish}

not seem to depend closely on temperature. Having no opportunity of avoiding the cold, they sink to deeper parts of their watery domain at the approach of winter, and if the chill penetrates to their retreat, their vitality is diminished, their blood flows more slowly, they feel no need of food, and forthwith enter into a state of hibernation.

In deep lakes they sink beneath, below the reach of surface chills, and are sometimes caught with a hook through the ice. In the South their activity never ceases. Any one who has seen black bass feeding, must have been impressed with their immense power of movement. They soon become masters of the waters in which they are placed; sunfish, chub, dace, trout, young salmon, and even the ravenous pickerel, are devoured, as are also the young of their own kind. They feed at the surface on moths, flies, and frogs;

Natural Food

they turn over stones in search of crawfish and insect larvæ. In their stomachs have been found mice, young rats, snakes, and small aquatic birds. With such a varied menu, it is no wonder that the angler finds them at the proper season equally eager for fly-hook, trolling spoon, or live bait, and ever ready for a struggle which puts the rod and line to a severe test. They are fished for at night, as well as day, so that it may be assumed they are always feeding, the early morning hours being considered (next to late evening) the best time for angling. They are active, roving, merry fish, continually rising from the bottom to the surface, at times rising above it in 


\section{Fish and Fishing}

pure wanton play. The small-mouthed bass thrive in comparatively clear, cool, and rocky or gravelly streams, and in lakes or ponds supplied by such streams or having cold bottom springs. In lakes of the latter' character, it coexists with largemouthed bass in many instances. In such cases, the small-mouthed will be found usually at the inlet, or about springs, and the large-mouthed at the outlet or in sheltered, grassy situations. One of the features of the bass is its domestic habits.

\section{Habits}

The male and female pair off and together they form a nest on the bottom of gravel or coarse sand, in very rocky streams, on a flat rock. The male fish does the work of preparation by scouring with fins and tail a space about twice his length in diameter, forming a shallow, saucer-shaped depression, in which the female deposits her eggs, which are fertilized by the male, who hovers near by. The nest is careBuilding parents until the eggs hatch, the period fully guarded from intruders by the of incubation being from one to two weeks, according to the temperature of the water. The fry are then watched and brooded by the male fish for a week or so, when the young seek the shelter of weeds and grasses in shallow water. Probably fifty per cent. of the young are later devoured by adult fish. Many are the methods pursued in its capture, trolling with artifical lures, and with live bait, casting with the fly, and with bait, bobbing, skittering, and still fishing-all are the same to its hungry and ever-ready maw. 


\section{Popular Fresh=Water Game Fish}

Another species similar in appearance is the rock bass, or red eye, also the warmouth, the calico or strawberry bass, and the crappie, all found in the same waters as the black bass; but they are of little or no importance to the angler in comparison. The warmouth (called a perch in some localities) for its size is a gamy fish, so is the rock bass; both the latter rising to the fly, at times, but so do many of the common fishes, not game, to be treated in a separate chapter under that name.

\section{GRAYLING}

The American grayling, like the mascalonge, is confined to the Middle Western States, more particularly to Montana and Michigan; notwithLocality standing the many efforts to plant them in Eastern waters, including those hatched and shipped from Bozeman by Dr. J. A. Henshall in 1898 , they have resulted in no apparent good. I know of no place in Eastern waters worthy of being called "fishing" for grayling. The family Species consists of three species: Michigan, Montana, and Arctic grayling, the latter having the great dorsal fin much larger and more highly colored, the two former being very similar in both appearance and game qualities. It is a graceful, trimly built, and delicate-looking fish, colored more Habit like "mother of pearl" than any fish I know. Its habit is to lie at the bottom of deep, slow-moving, clear cold water, and it rises to the fly many times, swiftly darting back without taking 


\section{Fish and Fishing}

it. The leaping of the grayling is extremely graceful, both on the hook and in play, when not disturbed. As a gamy fighter it is equal to the trout, though it takes the fly much more quietly, most often while the fly is under water; then, in a flash, turns, like a somersault, fighting every inch its hardest to get back to the bottom. In size it Size rarelygrows more than two pounds in weight, Size the average being about a pound, but, with careful angling, quite a number may be caught from the same pool, as they invariably lie in schools together. Its food is mostly insects and their larvæ, small minnows, crustaceans, and other small creatures. They coexist with the red-throat trout, each seeking out such portions of the streams as are best suited to them. In fishing for grayling the smallest possible flies

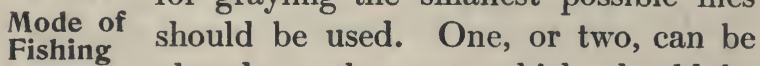
placed on the cast, which should be exceedingly fine. Good flies are black gnat, coachman, gray hackle, black hackle, iron-blue dun, red ant, and cinnamon. The rod, line, and leader can be exactly similar to those used for trout fishing. Cast down stream or cast across stream, letting the fly float down to the foot of the pool. When the fly has passed by, the fish darts up swiftly, and back to the bottom, often a number of times, seemingly as if afraid to touch it. But it is game, and the fly is at last taken; the same method is pursued; up goes the great fin to plunge it downward, fighting stoutly to get free.

A good deal of careful work is necessary in 


\section{Popular Fresh=Water Game Fish}

handling and playing the grayling. Gently keep the line taut all the time or it will surely get off; the slightest jerk will lose it, the flies Game and being so small, and its lips somewhat Leaping Traits tender; for that reason many fish get away. The grayling repeatedly breaks water after being hooked, and it makes an excellent fight beneath the surface, being much aided in its resistance, by its tall dorsal fin.

The Michigan grayling may be found in the Au Sable, Manistee, Marquette, Jordan, Pigeon, and other rivers in the northern part of that State. It may also be found in the river Boyne and Pine Lake. The Montana grayling is found only in the tributaries of the Missouri River, Where above the great falls; in Sheep and Tenderfoot creeks, tributaries of Smith River, in the Little Belt Mountains, and the three forks of the Missouri-the Gallatin, Madison and Jefferson rivers. But the ideal home of the Montana grayling is in several tributaries at the head of the Red Rock Lake, in the upper reaches of the Madison, where the water is rapid, though unbroken; also the Beaver Creek, in the upper cañon, is an ideal stream. The best season for fishing is in September, October, and November.

\section{TROUT}

Next in order to the salmon is the large and important group of trout and charrs. There are twenty-four species and subspecies of salmon 


\section{Fish and Fishing}

trout, and thirteen varietal forms of the charrs. It is only possible to mention one or more of the most popular of the various species of Frout trout, the subspecies being similar in habit and character as well as the method of angling for them. For more detailed accounts the reader should consult volumes devoted entirely to them.

The American cut-throat, or Columbia River trout (Salmo clarkii), ranges in the coastwise streams of Puget Sound, south to Elk River, California, and its various forms eastward to the headwaters of the Rio Grande and the Utah Basin. The habits of the cut-throat are similar to those of its Eastern brother, the fontinalis. Wherever a pool exists, created by an offshoot of the main stream, wherein a shelving rock or overhanging trees form a sheltering or shady nook, a single cut-throat of good size is found, sovereign of the domain from which it drives the grayling and whitefish. In the larger pools, caused by the subsidence of the current in deeper water, it appears to live in harmony with these fish. Wherever the cut-throat lives within access to salt water, it doubtless ranges seaward as far as the salmon. Under these conditions, a silvery coating is assumed, and the black spots disappear, leaving but few traces of its fresh-water garb. When taken in salt water, it is found to be of increased size, upward of twenty-five pounds, and is generally called by market men and anglers the "salmon trout." The cut-throat is an omnivorous feeder, 


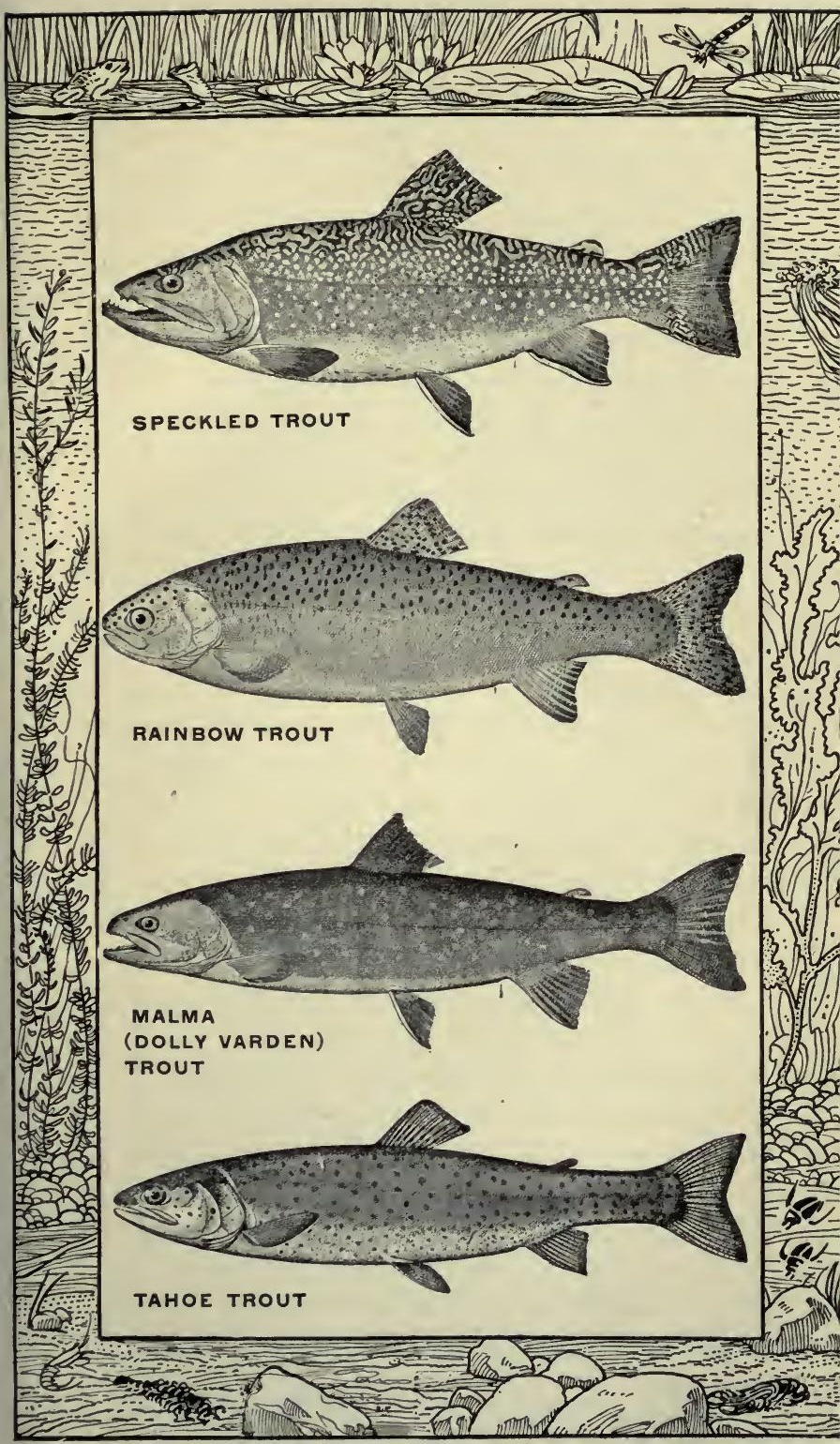





\section{Popular Fresh=Water Game Fish}

minnows, insects, worms of all kinds, grasshoppers, fresh meat; and, above all, the artificial fly, when properly and skilfully manipulated, is most attractive, for it is at all times, when the water is clear, a surface feeder, though not particular as to color or form of the lure presented to it. The angler, visiting the native waters of this fish, needs only to stock his fly book with flies used in luring the Eastern brook trout. If he visits the Yellowstone or any of the large rivers containing this fish, it would be well to have a fly rod not less than eight ounces, as the fish attains to the weight of six or seven pounds. A subspecies is found in the Yellowstone River adjacent to Livingstone, Montana. It is a typical trout water, where the fish take the fly viciously with deep and long surges to escape the hook.

'The Rio Grande trout is more familiar to the anglers of the Middle West, particularly those residing in Colorado. It is an exceptionally game fish and a choice feeder, takes the fly greedily and fights hard under restraint. In the opinion of a resident angler it is "the best fish that swims in any waters of the earth." There is little difference between the Rio Grande and Colorado River trout. The latter seems to have attracted the attention of the anglers of that section to a greater extent. It is the objective of nearly all their outings, and its game qualities are heralded in every sportsman's journal throughout the country. It grows to a weight of over nine pounds, though the average is much less; but it takes the artificial 


\section{Fish and Fishing}

fly with avidity, particularly the coachman, black hackle, June-spinner and the black prince. The best month for fishing is July.

One of the most interesting of the salmon trout is the Lake Tahoe, or silver trout. This fish grows to a weight of twenty-five to thirty pounds and spawns in the depth of the lake. It is probably sought for by a greater number of anglers than any other fish of the Pacific slope waters. Being reached in a.few hours from San Francisco, the resident anglers of that city make Lake Tahoe the Mecca of their outings, and no visiting angler rounds up his fishing tour unless he essays these big trout.

The hotels at the lake are crowded all through the season, for the fish are large and numerous. The Lake Tahoe trout is found in the following lakes and rivers: Lakes Tahoe, Pyramid, Webber, Donner, Independence, and in the rivers Truckee, Humboldt, Carson, and in most of the streams of the eastern slope of the Sierra Nevada.

The steel-head trout (Salmo gairdneri), also known as the hard-head, is a large sea trout growing to a weight of twenty pounds, or more, and is migratory like the salmon, ascending rivers to spawn many hundreds of miles into the State of Idaho, and into other sections. It inhabits coastwise streams from British Columbia south to Santa Barbara, California, and those west of the Cascade Range. It is very abundant in the Lower Columbia, the Russian, and Klamath rivers. Its edible qualities are inferior to those of the same 


\section{Popular Fresh=Water Game Fish}

family east of the Alleghany Mountains. But if inferior as food fishes, the steel-heads possess all the game qualities of Eastern trout. They are fly takers when in the streams on shallow ledges of rock in the lower waters. On taking the natural bait the steel-head is apt to surge deep and strong, but when fastened on the fly for which it rises, it is an acrobat, leaping repeatedly from the water. These aerial flights lead the angler to believe that it is closely allied to the rainbow trout, the only trout west of the Rocky Mountains-with the exception of the stream steel-head-that will rise and leap frantically into the air.

The rainbow trout (Salmo irideus) are typical game fishes of the salmon family, and are equal in fighting qualities, when found in streams of moderate size and depth, to the leaping salmon of Lake St. John. It is one of the most muscular and resourceful of fishes for its size, rising freely to the fly, leaping on a slack line, and fighting literally to the death.

In Eastern waters, the rainbow appears to have acquired increased strength, and certainly greater leaping powers. It is also the hardiest of the salmon trout, for it will thrive in water of a higher temperature than is suitable for other species. Though a gormand in its appetite, it is cleanly in feeding, liking best the live minnow or insect on the surface. A swimming grasshopper is irresistible, and no fish rises so freely to a cast of artificial flies.

There are five subspecies of rainbows; the 21 


\section{Fish and Fishing}

most prominent being "the brook trout of western Oregon," and the "McCloud River rainbow trout," from which stock the Eastern and Middle West were first stocked in $\mathbf{1 8 7 0 .}$

Another important subspecies is the Shasta rainbow, which rises freely to any of the standard flies and grows to a stream weight of five or six pounds. It yields exceptional sport in waters where it is new to the angler's rod. The dressing of feathers which it prefers, when tied on No. 10 sprout hooks, are those of the March brown, coachman and brown hackle. The habitat of this trout is in the streams of the Sierra Nevada, from Mt. Shasta southward, but it is best known in the McCloud River. Two other rainbows are the Kern River trout, and the golden trout of Mt. Whitney, California, both being of peculiar interest from the fact that they are found in no other water than the Kern River and its tributaries. Both are very game, taking the fly on the surface and fighting hard by deep and long surges. The Mt. Whitney trout is the most beautiful in color of any salmon trout.

Of the three foreign species of salmon trout transplanted to American waters, the best known by anglers is the German or brown trout (Salmo fario), which was planted in 1883. An unpardonable mistake has been made in planting them in small streams where they feed on and destroy the native fontinalis. Being able to exist and thrive in water of a higher temperature than is adapted to other trout they should never be placed in 


\section{Popular Fresh=Water Game Fish}

streams which the latter inhabit. In the waters of the Eastern States the brown trout grows very rapidly, averaging nearly a pound increase in weight in a year. It is in its prime for the rod from the 1st of May to the middle of September, during which period it rises freely to the fly, better in the evening than in the brighter hours of the day, a habit equally prevalent among other trout. I have had them repeatedly leap above the surface on the fly in the swift running waters of the Beaverkill (N. Y.), and have caught them up to three pounds in weight, living in the same pools as the small-mouthed bass; indeed, I have more than once caught a double of brown trout and bass. The flies most luring are a small silver. doctor, red spinner, and beaverkill. I have caught many brown trout of large size in deep pools on the worm, phantom minnow, and silver soldier spinner; in fact it will go savagely for pretty nearly any lure.

Another foreigner is the Lake Leven trout (Salmo levenensis). It grows to the size of four pounds but the average is much less. It is about equal in fighting qualities to our native trout, rising well to the artificial fly.

The last of the foreign species is the salmon trout (Salmo trutta). Various popular names have been given to this fish, such as guiniad, bull trout, and salmon trout. Its habits are similar to our own native sea trout. It is migratory, and is found running up streams emptying in the Atlantic. It is a game fighter, but more apt to 


\section{Fish and Fishing}

take a troll of natural minnows or an artificial phantom than the fly, however carefully cast before it.

\section{CHARR-TROUT}

The charrs are more highly organized than the salmon trout; they live and thrive in wild waters of a temperature not more than $65^{\circ}$, and in whatever water they may be, they constantly seek the Charr= higher reaches to spawn. In New trout England, Canada, and also along the south shore of Long Island, one of these charrs (fontinalis), goes down to salt water and feeds, grows lusty, getting flesh of a deeper salmon and a more robust form, and remains in his new habitat until the instinct of spawning impéls it to migrate in the following spring inward and upward. Other fresh-water fish find a congenial habitat in salt water.

The Lake trout (Cristivomer namaycush), is known by many names. In the Great Lake region it is called the Mackinaw trout; in the Northwest it is known as the namaycush, Siscowet, in other sections buckskin, togue, forkedtail, lunge, tulade, and masamacush. It is a large fish, growing to a reputed weight of 100 pounds, but the average is about six pounds. The lake trout rises to the surface very early in the spring and the angler trolls for it on or near the surface of the water, the fish taking the lure viciously, but rarely jumping into the air. It takes the spoon well, but the favorite bait is a golden 


\section{Popular Fresh=Water Game Fish}

shiner or carp; the larger the bait the larger the fish caught.

We now come to the most beloved of all charrs, the native brook trout (Salvelinus fontinalis), the objective quarry for the skilled and the tyro in their mountain outings. Its structure is formed and fitted for its wild life in the tumultuous mountain brooks, shaped to breast the rushing rapids wherein it poises, self-contained in body, and, apparently, in spirit. It will leap over and sometimes swim up the centre of three feet of water of a dam over which a downpour twelve or more inches in volume is ceaselessly passing; or it can be seen in a quiet pool above the dam disporting, and leaping leisurely and lazily from the water. No other fish known to anglers possesses habits so free from grossness as the brook trout of the East. Its primary need is oxygen, and it seeks it in the upper reaches of strongly aerated mountain streams. There cast a fly, and when hooked, the trout seems to know every rift, nook, rooted hold of its rock-ribbed environment. In such streams, the trout are compelled to forage vigorously and industriously for food, and the wear and tear of vitality is constantly at work on the muscles; it finds little rest where no deep pools abound to which the fish can retire for security, repose, and digestion. Very different is the life in deep-pool lakes; there they feed mostly at the bottom, coming to the shallows and surface at sundown.

The Dolly Varden trout (Salvelinus parkei), also known as the bull trout, is widely distributed 


\section{Fish and Fishing}

in the Western waters of the Rocky Mountain water shed. It is found as far North as Alaska, and South to the upper Sacramento River, thence eastward to Montana and Idaho waters, and, in these places, is called the red-spotted trout, malma, Golet, and Oregon charr. None of the trout or charrs rise more freely to the artificial fly than the Dolly Varden. The Eastern charr, that goes to the sea, is the fontinalis, the Western one is the Dolly Varden. The effect of their sojourn in salt water is shown in their rapid growth, thicker body, and striking change in coloration. The Dolly Varden grows to a weight of seven pounds, and when taken, as it often is, in a salmon pool, the angler is apt to mistake its strong surges for those of a small but sprightly salmon.

Perhaps no fish has been a subject of so much discussion as the Sunapee trout (Salvelinus alpinus aureolus). It is only found in Sunapee Lake and Dan Hole, Carroll County, both in New Hampshire, and in Flood's Pond, Ellsworth, Maine. These waters are very deep and pure, and contain large numbers of landlocked smelt and crustaceans, upon which the trout feed, to such repletion that they do not rise to surface food of any kind, certainly, most infrequently, if at all, to the artificial fly; but on the trolling spoon, or live smelt in still fishing, they show grand fighting vigor. The bait should be lowered sixty to seventy feet, ground baiting for several days before fishing being most fruitful in scores. 


\section{CHAPTER II}

\section{Popular Salt=Water Game Fish}

\section{LEAPING TUNA}

If I were asked to mention the salt-water angler's paradise, the reply would be, without hesitation, the beautiful waters of Avalon Bay and the Islands of San Clemente, Santa Catalina, and Santa Barbara, on the California coast. It is there, if anywhere on earth, the true angler may see "high ideals in big-fish angling, and fair play to the game." He may see "fishing for tuna, tarpon, and the great black sea-bass, the trio which are the tiger and elephant trinity of the angling world." Yet such monsters are taken Big Game on seven-foot rods, made in two pieces, and not weighing more than twenty-five ounces. On such rods, fish weighing 400 pounds have been played and gaffed, after tremendous battles where both sides have equal chances to win. There the novice learns his task at a cost in new tackle that comes high. Even the veteran, now and then, to save his life, lets go a rod he fain would keep. Angling by such methods is but of recent date, according to the author- 


\section{Fish and Fishing}

ity of C. F. Holder, whose influence in holding up a high standard of sport is highly commendable.

Tuna angling is a modern sport confined so far as known, to Santa Catalina, California. The locality is limited to about four miles of coast in the lee of the Island Mountains Limited which afford several open bays, generally smooth, the wind only blowing part of the day, thus giving the angler perfect conditions, without which tuna fishing would be impossible and extremely dangerous.

The tuna is an ocean wanderer, found in many parts of the world, known as the horse mackerel, tunny, and great albacore. Everywhere it is a terror to the smaller denizens of the deep,

Range of feeding on blue-fish, menhaden, herthe Tuna ring, in the Atlantic, gorging itself with the great flying fish in the Pacific. For centuries it has been caught in great nets in the Mediterranean Sea. From the St. Lawrence, along the coast of Nova Scotia, down to Cape Cod

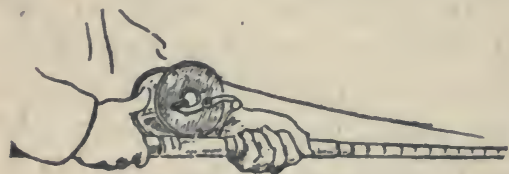

Position before the strike. in New England, it is common, and at times is harpooned by the f is hermen. Some specimens attain a weight of 1,200 to 1,500 pounds.

The "leaping" tuna has been rightly named by its champion, Charles F. Holder, author of "Big 


\section{Popular Salt=Water Game Fish}

Game Fishes," to which I am indebted for much information in these notes, as I have not, as yet, personally had an encounter with this fish.

The tuna, like the tarpon, is a lofty tumbler, leaping gracefully into the air after its prey, the flying fish. Its large size and graceful build, with its broad-forked tail, show a model of speed; it is a beautiful fish, and when in the water appears to be green, but on being landed, the upper portion is a bright iridescent blue, the under part being grayish silver. No more inspiring sight can be imagined than a large school of these fish. They arrive in immense num-

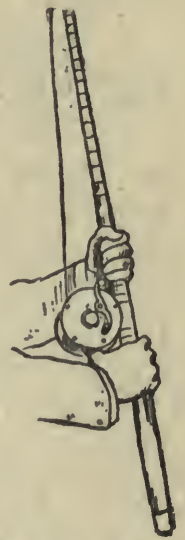

Striking the fish. bers at Santa Catalina between the 15th of May and the 15th of June, and at once divide into Its Leap small companies of fifty to one hundred, playing on the surface, moving about in triangular form, with their spike dorsal fins out of the water. Suddenly, in different sections, may be seen a great splash of white spray; dozens of flying fish, scattered like gigantic dragon-flies, skim along in frightened confusion. This is the first signal to a host of impatient anglers who have been watching for days for the arrival of the bird fish upon which this giant comes from the deep ocean for slaughter.

Such a game fish must needs have special tackle, if taken in true sportsman's style, and such tackle, 


\section{Fish and Fishing}

unless of the very best and most expensive make, has no chance whatever. Even the boats are "designed specially for tuna fishing, being broadbeamed launches, built for three persons; Special Boats two anglers who sit side by side in chairs facing the stern and the boatman acting as helmsman, gaffer, and engineer of the three, or more, horse-power gasoline engine. Overhead is an awning which is raised by the gaffer when the strike comes; each boat has a flag bearing the figure of a tuna which is thrown to the breeze the moment the fish is hooked."

The fish are rarely seen near the mainland, the islands, where they feed, being twenty miles from shore. Naturally, so active and bold a fish taken so far from shore requires good, patient, as well Activity as strenuous handling, and the novice would do well to make a preliminary trip

- to watch the veterans in their struggle. Anglers are now enabled to purchase rods, reels, and lines of special make for this fish, similar, and of the same character as those used in tarpon fishing, though of the two, the tuna being more active requires a little stronger tackle.

The rod may be either of split bamboo, greenhart, or noibwood; perhaps one of each would be wise and come in useful. They all should be from seven to eight feet long, made in two parts, a butt Rods and tip, the latter of medium pliability, not so stiff that it will not bend, nor yet so pliable that a heavy fish cannot be lifted. They should have double-bell guides, silver mountings, 


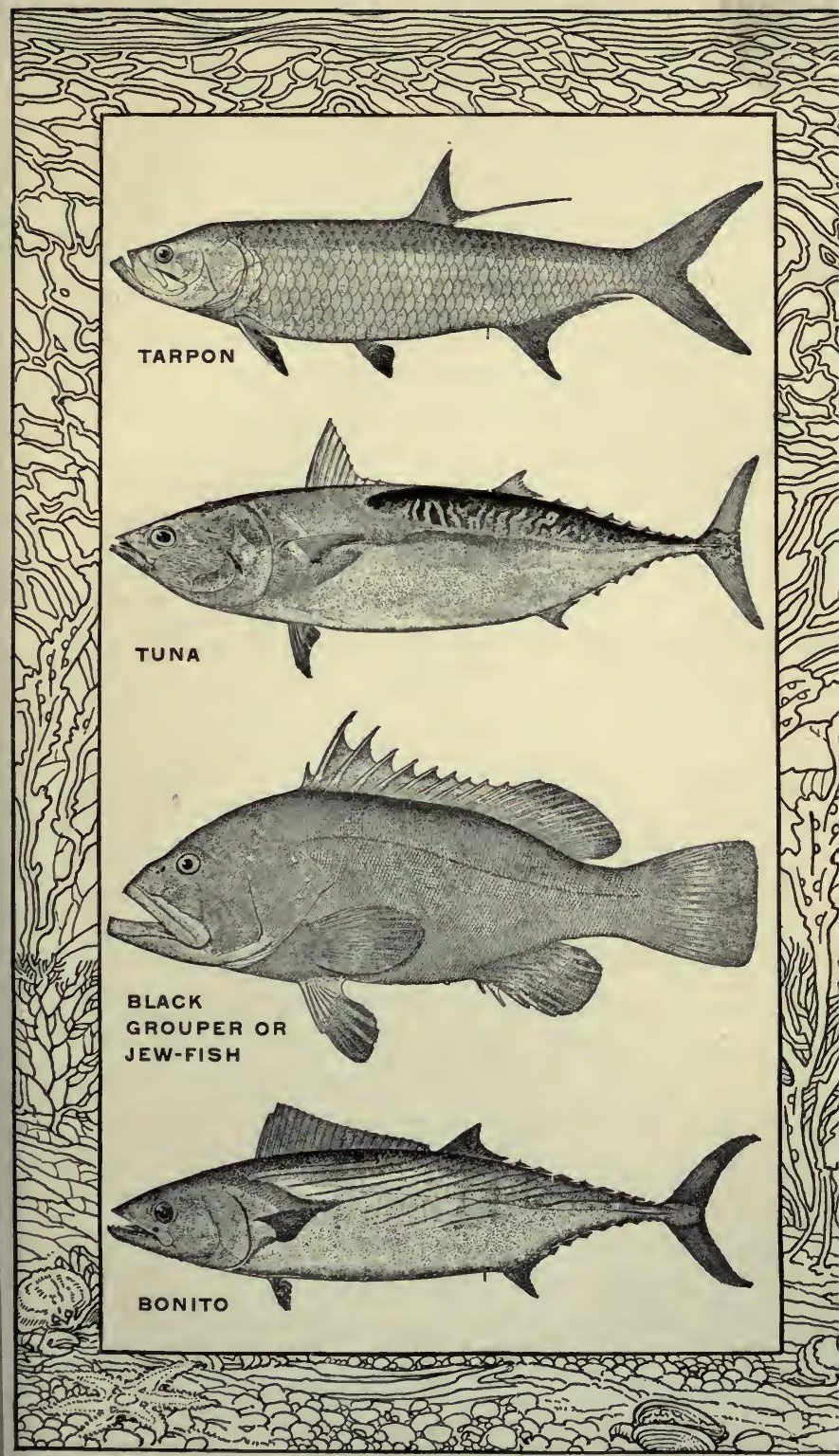





\section{Popular Salt=Water Game Fish}

and weigh about twenty-five ounces, each rod being provided with an extra tip.

A number of reliable makers are now supplying special tuna reels, some having excellent ideas that others lack. It is a question of taste. A good Reels reel costs from $\$ 30$ up, these, of course, Reels being perfect machines, adjusted so well that a whirl will cause the handle to run for some time, and they are not likely to fall apart during a

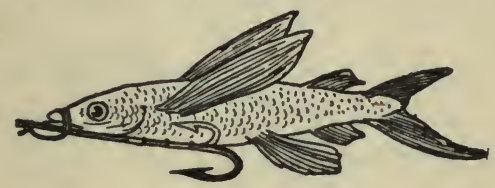

Baited double hook.

hard fight. It should have a capacity of 300 yards of Cuttyhunk line, when wet, with a drag to prevent overrunning; and attached to the lower crossbar there should be a leather pad lined with moose hide. The brake should never be used unless the line is wet, as the friction will burn the line. The reel should be perfectly fast to the rod. No device where it slips into a socket will do; a loose reel and the game is over; so have it lashed to the rod perfectly immovable. Concerning the necessary Lines lines, choose one overstrong, because confidence in the capture of the fish is greatly to be desired. All anglers know that "doubtful feeling," when a fish is going at a ripping speed, and then all of a sudden makes a bound into the air. The "confidence" in the line's strength 


\section{Fish and Fishing}

makes the playing more free, and the mind is at rest. For that reason choose No. 21 or 24 Cuttyhunk, tested to pull forty-two pounds to forty-eight pounds dead-weight. By such a line the tuna has been known to pull a heavy boat ten miles. The leader can be six or seven feet in length, of phosphor-bronzed wire, and the next ten feet of line should be doubled, as it is liable to chafe on the back of the fish in a long struggle.

Every angler has his choice knot in which to

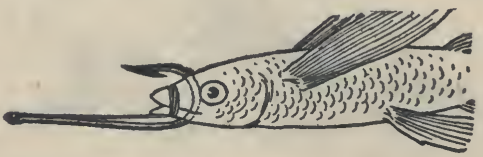

Baited single hook.

tie the line to leader, but a strong, sure and safe one is absolutely necessary; the same choice is Rig maintained regarding hooks, though the favorites are a Van Vleck or an O'Shaughnessy, the latter a No. 10/0. Between hook and line there should be three strong brass swivels.

The best, indeed the only, bait used is a large flying fish hooked in various ways according to Bait the angler's fancy. The tuna always strikes at the eye of the bait, so that most anglers hook the bait through the lips with the barb pointing upward; then sew up the mouth to make the fish run smoothly.

Everything being made ready, the fisherman starts for the ground before daylight; others follow the schools at all times. Many consider a rising 


\section{Popular Salt=Water Game Fish}

tide best, but like all game fish, the tuna has its off and on times for taking the lure cast before

it on its onward rushes for the flying

Casting prey. Sometimes the water swarms with
Bait them on the feed, but they will not strike. The advantage of being among them when the flying fish leaps from the water, with the tuna after it, is great, just as when a trout leaps for the natural fly and an artificial fly is cast in its place.

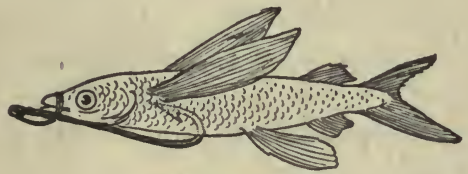

Way to bait, hook.

But when the bait is snapped up, the game has begun, though hooked is not landed; like the tarpon, many are hooked and not boated; while the reel is heard to sing such a tune as no other fish can make; and so the battle rages on equal terms, sometimes for hours, and miles are cut through the water at a spanking rate before the gamy fish is Gaffed brought alongside. By no means subdued or conquered, it lashes the water with its broad tail, even at the time it slides into the boat, fighting continuously from the beginning to the time the gaff goes home. Many a fish is lost at that critical moment, and a cool, business-like gaffer is a decided advantage in tuna fishing; for a more well equipped adversary the angler cannot imagine, nor does he wish for such, unless en- 


\section{Fish and Fishing}

dowed with more than average strength, nerve, and endurance.

\section{TARPON}

Tarpon fishing with rod and reel is a modern sport of comparatively recent date; twenty years ago no attempt had been made to take it by this method. To-day, angling for this magnificent fish has become an established recreation in the famous resorts where they abound; many clubs have been formed in which members have strict rules whereby tackle shall not exceed that used in other game fishing. The first tarpon

Taking taken in this way was by Wm. S. Jones, of Philadelphia, at the Indian River Inlet. It weighed 130 pounds and was six feet in length, fighting the angler over two hours before it was brought to gaff. The incident aroused much interest among anglers all over the country, and Jupiter Bay soon became a pilgrimage of determined fishermen bent on trying their luck on so formidable a foe. That they were there, ready to receive them, was proved, and a season rarely passes by, that the total catch does not foot up 300 to 400 fish.

This Indian River, so called, is in reality a beautiful lagoon, or inland sea, of varying depth and width, fairly alive with fish; the river bed in parts is a solid mass of oysters and other shell-fish, but the great attraction that draws the tarpon, sharks, and other monsters, is the vast shoals of 


\section{Popular Salt=Water Game Fish}

mullet upon which they feed. All down the river, from the mouth of the St. Lucie past Fort Pierce, I saw these lively mullet, like little streaks

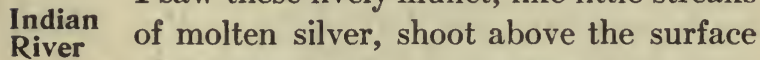
of the glassy water. Sometimes I observed a great dark form dash away from our sailboat driving the little mullet into the air, hundreds at a time. The Indian River inlet is, at the mouth of Jupiter Bay, not over a mile in width, but in the deep blue water one sees great monsters wallowing, very few feet from the shore. Lake Worth lies but five miles southward; from there down to Miami, round the peninsula, to Fort Myers, and Tampa, the tarpon is found in its greatest abunLocality dance. Other localities made famous by anglers are Captiva Pass, Boca Grande Pass, Marco, Naples, Pine Island, and Homasossa. On the Louisiana coast the tarpon is called the grande écaille; along the Texas shore the tarpon, and savanilla. The tarpon is a migratory fish, moving north along the coast of Mexico up to Louisiana. They appear around Migration the Florida coast early in February, increasing rapidly in numbers in March, April, and May, entering rivers sometimes' ten miles from the mouth. The tarpon first arrives in Aransas Pass, Texas, early in March, coming up the coast in schools from the South, journeying onward along the coast to Galveston and other points. From the middle of April they congregate in that locality in large numbers, but will not take the bait, apparently this being their spawning 


\section{Fish and Fishing}

season. The latter part of May and June they take the mullet readily.

The tarpon is said to attain a length of over eight feet and a weight of 400 pounds; as a food fish it is of no value, and only the larger specimens are kept for mounting as trophies, the smaller ones Size being released to grow and be caught on a future occasion. Some are so injured during the combat that they are retained, and the beautiful scales taken off to be sold by dealers as souvenirs. Many scales are now used as postal cards, the lucky anglers sending them to distant friends, writing name, date and weight of fish on the inside.

The tarpon is, in its habits, a wanderer and a voracious feeder upon mullet, sardines, and other small fry, dashing into thick schools, devouring Habits enormous quantities, going into shallow bays, and up various rivers in search of prey. To the seine fisherman it is a dangerous fish to catch, tearing and smashing the nets to shreds in its leaps and efforts to escape. A first view of the tarpon is a sight not easily forgotten; in cruising 'round the Florida coast you see an enormous mass of shining light, like a blanket of silver dollars; up it goes high into the air, sometimes twenty or thirty of them, and you may sail right in the midst of them and fish for days before you catch one; at other times the first cast is rewarded by a magnificent strike that sends the shivers right through you. At times there is no question but that the sport is dangerous, even hair raising. 


\section{Popular Salt=Water Game Fish}

Incidents are recorded where the fish leap headlong into the boat. If first seen at close quarters, especially front view, with wide-open Dangerous jaws and blood-red gills, it is a most
Sport sinister object, as ugly a customer as one wants to meet. Its large eyes glare, its lower jaw protrudes, highly suggestive of a determined nature to smash things in general, and the novice trembles for a time, wishing he were safe on shore. The tarpon is a long, slender, thin fish of the herring type. Its tail is deeply forked, a powerful organ by which it leaps; the upper portion of the back is of a metallic purple-blueish cast; the rest of the body iridescent silver. Its scales are remarkably large, some on the big fish being $3 \frac{1}{2} \times 3$ inches, the exposed half seeming to have been dipped in molten silver and then frosted.

One of the largest fish taken was that by Dr. Howe at Tampico, Mexico. It weighed 223 pounds, had a length of 7 feet, 2 inches, and girth of 46 inches. In a little less than a

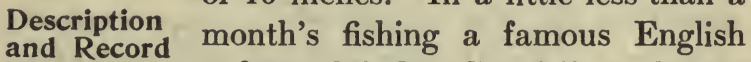
rodster, W. H. Grenfell, took 100 fish at Boca Grande. But this is a record not often reached; it is only in a few localities, and very seldom, that they are really plentiful.

Most of the dealers have now a regulation tarpon tackle; everything can be got in the large cities to fit the angler out for the fray. Von Hofe has a special rod, reel, and line of their own make. A member of the firm having held the world's record for a time makes it a surety that their expe- 


\section{Fish and Fishing}

rience may be relied on to furnish tackle that suffices. But tastes differ somewhat, both as to Tackle length of rod and thickness of line; those inclined to be humanly reasonable use longer rods and lighter lines; such a rod may be $7 \frac{1}{2}$ feet long, having a single long tip and short butt, made either of greenheart, snake wood, or noib-wood; the latter has come to be a favorite wood among certain anglers, being firm, close, and of elastic fibre, yet remarkably light. The Rod standard tarpon rod of split bamboo, 7 feet long, weighing 26 ounces, has been known to take a 600 -pound fish. Of course, the difficulties in landing large fish increase with the length of the rod; it is wise to possess two or more rods (if the angler's pockets are deep enough), and they should be kept in a stiff leather case made for the purpose. For such fishing it would be Reel the height of absurdity to use a common or cheap reel. Twenty-five dollars up to $\$ 60$, is none too much to pay, and it must hold 600 feet of wet No. 21 Cuttyhunk line, or good linen of equivalent size. It should be fitted with a good drag and have a leather or rubber thumb pad (former preferred), fastened to the crossbar to press against Line the line. In the matter of lines the angler will do well to have several of various sizes, the novice beginning with No. 25; as he becomes expert he can use No. 21. Skilful anglers have taken the largest fish on No. 18, which is as light as possible, with safety. These lines cost from $\$ 3$ to $\$ 4$. 


\section{Popular Salt=Water Game Fish}

Regarding hooks, quantity as well as quality is essential, the Van Vleck perhaps being most used, though the O'Shaughnessy 10/0 has its followers. The hook is fastened to a snell of phosphor-bronzed wire five feet in length, divided Hook into three lengths each connected by a swivel. Several dozens of these snells should be provided, costing, complete, fifty cents each. This makes up the tackle. A leather rod rest makes fishing easier work, and can be fastened either to waist or boat seat; without such a convenience, the fishing, especially when waiting, grilling in the heat for a strike, becomes a nuisance.

The night before fishing the line, if new, should be stretched, and it should be wet on arriving at the grounds, and if the boatman is a man of experience, he will get your reel and lash it tightly to the rod, whether it has a patent fastener or not.

The pleasure of tarpon fishing to the angler is doubled, especially if he be a novice, in securing the right kind of a boatman, one with a cheerful, yet respectful disposition, above all, one who knows his business, and is able, as well as willing to show the peculiarities of the ground. For a great deal depends on tides, wind, and a knowledge of the habits of the mullet. Lastly, but not least, he should have a cool head, quick A Good
Boatman short, know thoroughly how the work should be done, and be able to direct others, and let them do it. When the fishing ground is reached 


\section{Fish and Fishing}

the first thing to be done is to screw the rod rest to the seat between the angler's legs; then the line is unreeled, fastened to the snell, and the hook is baited. Meanwhile, the angler is seated in his chair reeling off with his left hand the length of line which the boatman considers requisite, sometimes thirty or fifty feet, according to the location of the quarry.

The best time to cast the bait is at the beginning of the flood tide, though the change to the ebb tide is good. When the mullet come in to the inner

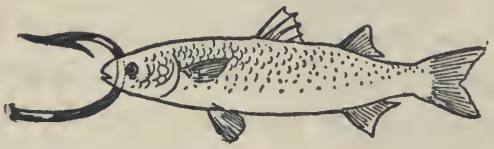

Mullet bait for tarpon.

waters, the fishing is poor. An interesting article that appeared in "Outing," says: "Tarpon do not make a first attack upon their food with their mouths. They have no teeth except a roughening on the edges of the lips, sharp enough to cut the best line instantly, if it comes in contact with them. They secure their food by striking with their tails, and then turning about to pick up the fish stunned by the blow." As soon as the tide has turned and the fish are feeding, having the bait properly fixed on the hook ready Time of to cast, say forty feet astern of the boat, the angler is waiting, holding the rod across his lap, right thumb on the thumb brake, the left grasping the cork grip above the reel; the 


\section{Popular Salt=Water Game Fish}

tarpon rushes at the bait with a tremendous blow. Opinions differ much as to the wisdom of striking immediately; some give a little line, but I am inclined to approve Mr. Holder's advice, "to sway the point forward and strike at once, give a powerful backward sway, the thumb pressing hard on the leather brake." The fish will at once jerk away, but the angler will repeat the strike, thus setting the hook in the jaw. The fish struggles violently while the rod must be held up as firmly as possible, "giving the butt," then slipping it into the leather socket.

In tarpon fishing there are many strikes, few hooked, fewer killed. It is well known what tantrums the tarpon is capable of, above and below water, and it need not be repeated here; suffice to say, the method of turning and bringing it toward the boat, after much line has been given, is to keep the fish well in hand, and con"Pumping" stantly to "pump." The rushes must be stopped by the thumb and upper-hand pressure, and the moment this is accomplished seize the reel handle and turn; then drop the tip very low, and with both hands, the right on the brake, lift steadily back until the rod is vertical; then lower the tip suddenly, reeling rapidly; each time the angler gains several feet. By these short "pumps" the fish is easier brought Gaffing alongside. If the fish is not desired as a trophy the gaffer seizes the double portion of the line, inserts a short gaff just beneath the lower jaw, and holds the fish while it is unhooked 


\section{Fish and Fishing}

and then cast off. If the fish is to be kept, it is got into position, and the gaff placed under the head and jerked heavily upward between the gills and the tip of the jaw, and the fish's head held partly out of the water against the boat while it struggles. The boatman steps on the rail forcing it to the water's edge and slides the fish in upon the canvas at the bottom of the boat; if the tarpon still struggles it can be thrown over it. Some anglers kill the game with a revolver or a club. If the fish is firmly hooked, the boatman now cuts the line or unfastens it and baits a new hook, and the game is repeated as before.

\section{BLACK SEA-BASS}

This huge salt-water giant is another ocean wonder taken on rod and line within the last few years; its fighting qualities mainly consist in bulllike resistance, savage tugs, and towing the boat and anglers, sometimes for hours till tired. Then it is gaffed and rolled into the boat. It does not, like Range the tuna or tarpon, make long rushes, or leap above the surface, but generally goes deep down and along. It is common both on the Atlantic and Pacific coasts, where it has been caught weighing up to 500 pounds. In its general structure it closely resembles the fresh-water bass, and is often miscalled the black grouper, and Florida jewfish, but the two latter are distinct species.

Along the California coast, especially around 


\section{Popular Salt=Water Game Fish}

its islands, there are vast submarine forests of great density, immense, broad, deep-green leaves, growing to a length of several hundred feet, swaying back and forth in the current, forming a forest maze of sea-weed so thick as to be hidden from Habitat human eyes. Here, in the deep blue water is the home of the gigantic black sea-bass. Innumerable smaller fish of many kinds swim in and out of the tangled mass, while the monsters slowly move among them, at times darting after them churning the water into a veritable maelstrom. To such an environment the sea-bass is supposed to arrive in April. About July and August, the fish spawns, and fish caught at this time are filled with enormous masses of eggs which are deposited under the weeds in shallow water about twenty feet deep near the shore. During this time the fish are voracious, eagerly taking various baits. About the last of November they become scarcer and are rarely caught. It is supposed they run in schools at this season, and retire to deep water.

Feeding The young of the black sea-bass are
Grounds never caught; it is believed they stay and feed at the bottom below the weeds, and then go out to the ocean, and do not return till mature fish. Small fish under $\mathbf{1 0 0}$ pounds are rarely, if éver, seen.

Fishing for this giant as a sport has long been in vogue at the islands off Los Angeles County, and previous to 1895 they were caught entirely by hand lines; but about that time a large fish was 
taken with rod and reel by Gen. Charles Viele. Since then that method has been employed; it is

First

Taken on

Rod

a sport for two men in a staunch boat, but to try it single-handed is a dangerous experiment, especially for a novice, as a large fish may tow a frail craft out to sea and so capsize it. Expert and bold anglers have done it, but they are men who thor-

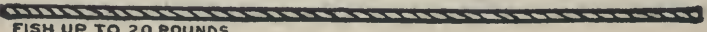

FISH UP TO 20 POUNDS

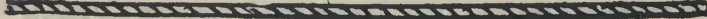

FISH UP TO 30 POUNDS

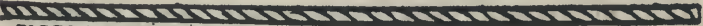

TARPON 60 ORIOO POUNOS

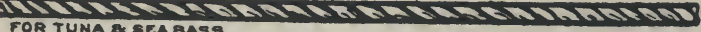

FOR TUNA A SEA BASB

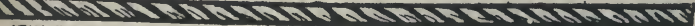

JEW FISH AND HEAVY LIFTING

Actual size of lines.

oughly understand the difficulties and dangers to be encountered.

The tackle used for this gigantic fish is identical with that used for tuna fishing; some use the wire Tackle leader, a few feet longer, and above it a fifteen-foot upper leader of strong cod line to give the boatman purchase in gaffing.

The fishing is done from an eighteen-foot launch, light enough for the fish to tow readily, large enough to hold, besides two anglers and boatman, three bass of 200 pounds each. The launch is anchored near the weed beds, the anchor being 


\section{Popular Salt=Water Game Fish}

buoyed so that it can be tossed over the moment the strike comes. Various baits are used, a live whitefish, or one-half a barracuda, also three or four pounds of albacore. These are taken on or very near the bottom.

At times there is a long and tedious wait for the strike, and when it does come, it is slow and deliberate, as becomes so dignified and portly a personage; after about twenty feet of line is gone and the bait properly in its mouth, a good solid strike is made; then the angler must be prepared for a violent shock, so strong and heavy, that it is Method of enough to turn the boat completely Method of round and away in an instant, the reel
Fishing working at utmost speed; the question of the length of time that the battle lasts depends entirely upon the size of the fish and the expert way in which the angler plays it; some bring it alongside in a remarkably short time for so heavy a quarry. It is then gaffed, the boat heeled over to the edge of the water, and the fish rolled in.

The Florida jewfish is found all along shore on the Indian River and various places round the peninsula. It grows to an immense

Jewfish and Grouper size and is caught near shore at the town of Tarpon, Aransas Pass. Its capture is identical with that of the sea-bass and the play is the same except that they have a habit of running to a deep-cavern in the rocks and there sulking.

What is known as the large black grouper, also caught on the Florida Keyes, attains a weight of 


\section{Fish and Fishing}

over 600 pounds, but it is comparatively scarce compared to the jewfish and bass.

\section{THE YELLOW TAIL}

The Pacific Coast is rich in game fish, or rather rich in anglers who, at all times, prefer to catch their quarry by game methods, and no fish is more

Good Fish= ing on the Pacific Coast popular or more deserving of that name than the lively and powerful yellow tail, or amber fish. Everybody takes a hand in the fun when the first great school comes up in the Bay of Avalon, about the 1st of April. Not all fish with rod and reel; hand lines are much in evidence, as the fish Size is a large one, requiring great strength to hold, the average being twenty-five pounds, some running up to eighty pounds. The tyro will find he is soon to be engaged with a tackle smasher, in fact rod smashing is the rule unless they are wielded by old or experienced hands.

The beautiful bay may be as calm as a mirror, when, all at once, a big school appears chasing the smelts right on to the beach, breaking up the water into a mass of foam. Scores of boats put out among them, and excitement reigns supreme, for the yellow tail is a fighter, a veritable "blue-fish" in shape and pugnacity, the true Color type of a real game fish. Its most conspicuous feature is the powerful forked tail of a vivid yellow, which is carried out in a stripe along the middle of the body, the back and upper 


\section{Popular Salt=Water Game Fish}

sides are a rich olive brown in the water, changing in the sunlight to a bright iridescent blue, the lower part being of a pearly silver. Yellow tails are voracious feeders, devouring immense numbers of smelts, flying fish, anchovies, and sardines.

Habits

They are often attracted and kept alongside the boat by "chumming" in both trolling and casting, or drifting. Like many other fish in this locality they arrive about the month of May in large schools, and then break up into small companies, of greater or less numbers, running North as far as Santa Barbara, and South as far as the shallow bays of lower California.

Many anglers make a visit to the Islands Santa Catalina and San Clemente, on purpose to get acquainted with larger game, but if the season permits they rarely go away without trying conclusions with the yellow tail and they are not disappointed in the result. For that

Style of Fishing reason a typical style of boat and boatman has developed specially adapted for this fishing. Gasoline launches from sixteen to twenty feet are run by the boatman who acts as engineer, guide, and gaffer; the boat has two chair seats at and facing the stern, though the angler may play the fish standing should he prefer or work better that way.

The tackle used is similar to that suited to tuna Tackle fishing; the rod not longer than eight feet, weighing not over twenty-five ounces, the line being a No. 15, or in some instances a 12strand Cuttyhunk from 300 to 400 feet long. The 


\section{Fish and Fishing}

hook an O'Shaughnessy No. 7/0 or 8/0 with a six or eight-inch piano-wire leader, in two links, and fastened with a double swivel.

The bait is either a smelt or sardine from four to six inches in length. To bait it, the hook is entered at the mouth coming out at the gill; then turned it is embedded in the belly of the fish, so that the entire hook, except the shank, is hidden.

Bait

The mouth is then wound with a five-inch fine silver wire attached to the hook, which prevents the bait from whirling too rapidly. At

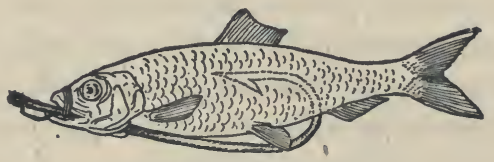

How to hook the bait.

times fish of exceptionally large size may be taken on a flying fish. The bait is then cast, and about fifty or sixty feet of line unreeled, and the launch kept moving slowly near the sea-weeds.

The fishing is best in the morning, from sunrise to midday, and on a flood tide. At the first sound of the reel, the boatman stops the engine, the fish at once turning the boat around, rushTime to ing here and there in frantic efforts to
Fish escape; so powerful are these lunges at times, that the angler is forced to give line, or the tackle goes. If the angler can withstand it, then the rod is too stiff for the code which holds and is most in favor with members of angling clubs. 


\section{Popular Salt=Water Game Fish}

The line is kept taut, reeled in when chance is given; if it is impossible to reel, a series of short "pumps" is tried. This ingenious device is used with effect in all game fishing.

"Pumping" is done by raising the rod slowly; then it is suddenly dropped, and the slack line Pumping rapidly reeled; this method repeated, gradually gains the day, and the fish is brought up. The yellow tail makes many rushes, and "pumping" comes into play each time; it is Chumming gamy to the last, up to the time the gaff enters its throat, and even after it is lifted into the boat. At times the fish is a coy biter; then "chumming" is the order of fishing; but when it is once persuaded sport is assured.

Being one of the commonest fishes of the Pacific Coast the yellow tail is rarely eaten; those weighing from fifteen to twenty pounds, if properly cooked, are excellent eating, though the larger ones are somewhat tough. There is another Amber genus called the amber jack, common Jack on the Atlantic and Gulf coasts, and plentiful in the vicinity of Palm Beach; it is caught weighing from forty up to one hundred pounds, and is also a vigorous fighter; but the medium-sized fish are the hardest fighters; this may be said of all game fishes in fresh as well as salt water, naturally the heavy fish not having the activity and snap of the younger specimens. 


\section{Fish and Fishing}

\section{SQUETEAGUE OR WEAKFISH OF THE}

ATLANTIC AND PACIFIC

In abundance and popularity this fish is better known to more anglers of the Atlantic Coast than any caught on the line. The reason is obvious; it Popularity is a bold and ready biter and any angler who knows how to go about it, lands from ten to fifty fish in one tide. It is a handsome as well as fairly nutritious food fish, affording considerable satisfaction to hosts of anglers throughout the warm summer months.

The squeteague is found on the Atlantic Coast, from Cape Cod to eastern Florida, and is abundant throughout this range, except in regions where its productiveness is interfered with by the bluefish. It is then more scarce. But it is Range nowhere at any season more plentiful, than in summer along the stretch of shore from Norfolk to Nantucket. Its wanderings vary; its habits are identical with the blue-fish, but the latter being the swiftest swimmer and the most voracious feeder, possibly interferes with the food supply of the squeteague.

In the South it is called the spotted trout, sea trout and salmon. About Cape Cod it is called the drummer; about Buzzards Bay, yellow fins; Names in New York and New Jersey, weakfish; in Virginia, blue-fish; the name squeteague is of Indian origin, and squit, succoteague, squitee, and chickwit, are variations of 


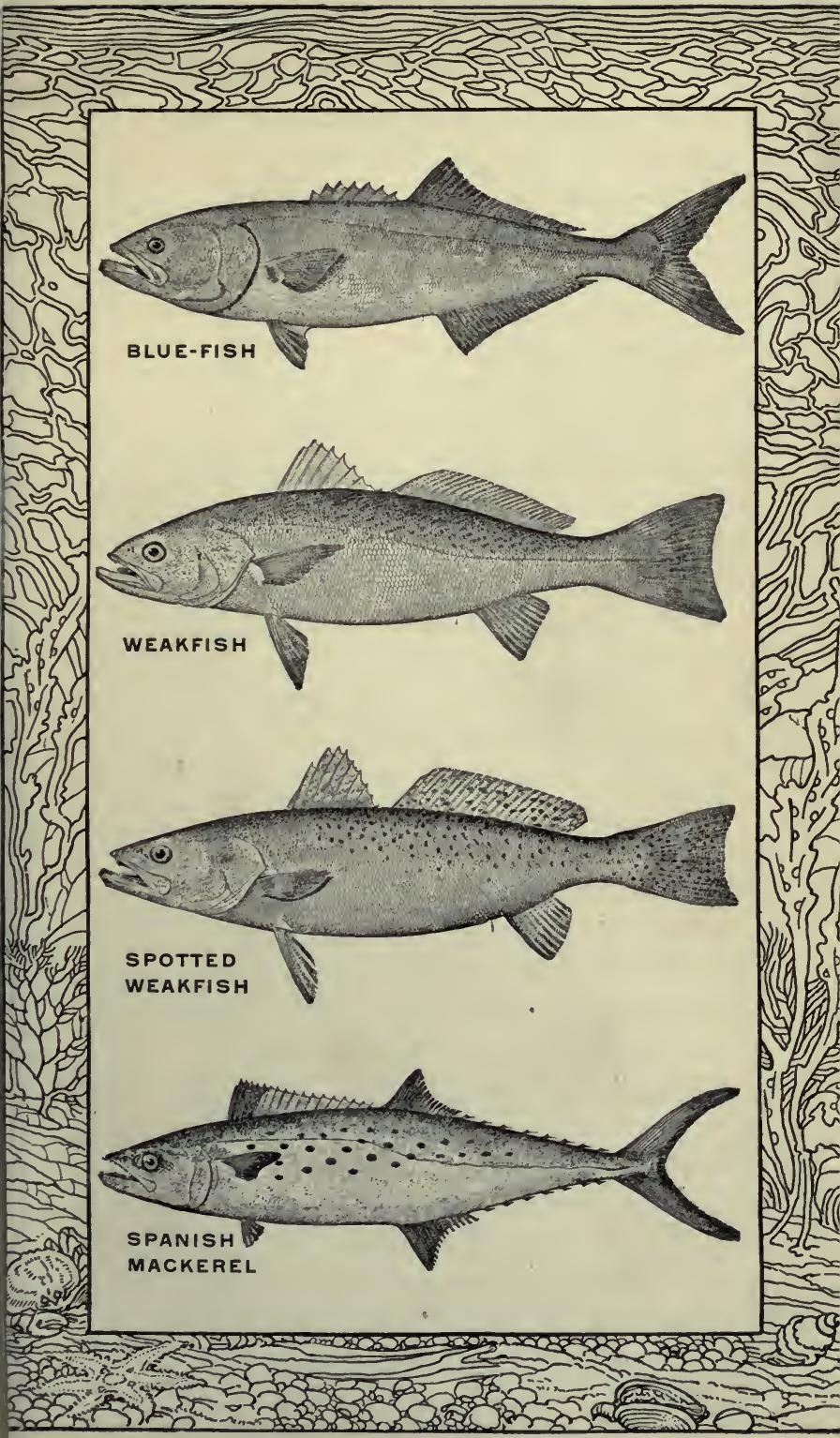





\section{Popular Salt=Water Game Fish}

the name in different ancient and modern dialects.

On the Pacific Coast it is known as the white sea-bass; other species, larger or smaller, are known as the gulf bass, sea trout, blue-fish, and Weight guaymas. The white sea-bass attains a weight of 100 pounds on the California coast in the vicinity of Santa Catalina. The average weight of the Atlantic species is from two to ten pounds, though specimens have been taken up to thirty pounds.

The name weakfish is not applied because it is not a gamy fighter, but for the reason that the bony processes of its mouth are unusually tender, so that it requires some skill to land a large fish without pulling the hook away.

The Cape Cod fishermen call the weakfish "drummer," because of the peculiar noise it produces when travelling in schools.

Weakfish are erratic in temperament and movements. To-day they are taken on a certain tide, to-morrow they will bite on another; sometimes a windy day is good, at others a calm day; thunder drives them to the bottom, and perhaps two days will intervene before they rise again to the surface. If sharks are in the vicinity, the tackle may be put up for the day; any loud noise in the boat, splashing of oars in the water, even the dropping Habits of the anchor too forcefully, has a tendency to drive them to pastures new. At low tide they go into holes and sand bars and stay there till the tide moves in; at night time they run 


\section{Fish and Fishing}

up the creeks to feed in the salt meadows, and there will take the hook freely, especially if baited with shrimps. Their habit of floating slowly into the bays with the incoming tide is mostly on, or near the surface, at flood, or nearly flood; the largest specimens may be seen at the top of the water, with the tall dorsal fin just above the surface; at times they will jump and splash much in the manner of trout.

The most favorable tide for catching them is generally considered the latter half of the flood and the first half of the ebb tide, in the bays and

Best Tide flats. In the ocean, the ebbing tide is best. It is necessary to "feel" for weakfish; sometimes they run on the surface, at other times on the bottom; it all depends on where the food happens to be in that particular place. It is well to try the bottom, then a few feet from the bottom, then at the top.

The usual rig for weakfishing is a light, stiff rod, not more than five feet six inches long, weighing ten to fifteen ounces, made of bamboo or greenheart, in two pieces, butt and tip, having good solid guides. Use a linen line, fine, but strong, and multiplying reel, holding 300 feet. The baited hook

Tackle should be attached to the line with a three or four foot double leader (without sinker), and allowed to drift with the current. If the current be very swift use a split shot, or a pearl squid. If the fish are not feeding on the surface use a one-ounce sinker, attached just above the leader with float. If fishing deep a $2 \frac{1}{2}$-ounce sinker should be used. 


\section{Popular Salt=Water Game Fish}

The four principal baits for weakfish are shrimps, shedder crabs, sand worms, and spearing. The last named are best, especially for the big tide runners. They are always hungry, so that Bait the bait most convenient to get will probably do. Whatever bait the angler may use, he must remember that "chumming" is one of the necessary things in weakfishing; "chum" constantly, but not too freely. Shrimps are the best to use for "chum," next best are chopped Lafayettes, porgies, sea robins, hard clams, and horse mussels.

There is never any doubt when a weakfish bites; it does not nibble round the hook, but takes the bait at one fair swoop and then starts off with it like a limited express with time to make up. It is a shy fish, easily frightened, and the man who uses a small line, light leaders and snells to the hook, is the one who is apt to have the best luck. When Landing the fish strikes keep a taut line all the time; lead the fish instead of tugging or hauling it, and let it run if it wishes, but lead it back and land it with a net. The latter is perhaps the most important part of the tackle. A net is sure and safe. Lifting the fish over the boat side leads to more losses than anything else. Weakfish may be caught in the surf by the same Ocean and method as that used in striped-bass Fishing fishing, with tackle similar but lighter. They may also be caught in the ocean, trolling in the manner employed for bluefishing. For bait use the artificial squid of bone, 


\section{Fish and Fishing}

cedar, or pearl. By these last two methods much larger fish are captured than those caught in bays and channels at flood tide.

The Pacific squeteague, popularly known on the California coast as the white sea-bass, ranges the coast even to Canada, and is most common from south of Magdalena Bay to Santa Barbara;

Pacific Squeteague and like the Eastern species is very uncertain in its movements and equally so in biting. The season may be said to be from May 1st to July, or even August; some seasons the fish is rare and will not bite; again it comes in numbers and affords sport long to be remembered. Charles F. Holder records, with a fellow-angler, taking ten of these fish, all over fifty pounds in weight, between 9 and 12 o'clock, not 100 feet from the beach in Avalon Bay. He further states: "A large school entered the bay and remained ten days, affording excellent sport. In our boat my companion and I each hooked a large fish at the same moment; one rushed ahead, the other darted astern, and we were at once involved in a most spirited tugof-war which resulted in the loss of one fish. At one time twenty or thirty small boats were fishing, and sometimes half of these would have 'bass' hooked at the same time; the scene, as the big fish towed the boats about, the cries and shouts Large as lines were parted, or rods succumbed, being a most animated one. I recall one rush of a bass hooked by a lady, which towed the boat almost entirely across the bay before the fish 


\section{Popular Salt=Water Game Fish}

could be checked. The game later tipped the scales at eighty pounds."

Of course, no such weakfishing occurs on the Eastern coast. The white bass is taken almost invariably in deep water along the rocks, and will often plunge down and sulk; then plunging along. it makes inshore rushes to reach deep channels.

Not all anglers use the rod, many fish with the line by hand; but the most artistic and humane use a rod of greenheart or bamboo, seven to eight feet long, weighing up to fifteen ounces, with a line of 15 to 18 Cuttyhunk, or even larger, as the fish are given to sulking and therefore have to be lifted, once in a while. The hook should be a 9/0 Limerick, with a piano-wire leader a foot Tackle in length. The bait is a smelt or sardine,
Used about six inches in length, and is impaled through the mouth, the point thrust through the belly of the fish and the mouth of the latter bound and fastened to the shank of the hook by a silver wire, which should be attached to every hook. To prevent the bait from whirling and the line from untwisting, the leader should have at least two swivels.

The method of fishing is to troll slowly, just outside the sea-weed; the fish nearly always swim on the surface, in small schools, and are easily recognized by their dorsal fins peeping above the

Trolling water. The fish are not easily alarmed, when the bait is cast among them, for the reason that it is the habit of the flying-fish to repeatedly drop with a splash in all directions, and 


\section{Fish and Fishing}

they are taken by the largest fish as food. For that reason, the flying-fish is often used as bait.

The white sea-bass average about forty or fifty pounds, small ones being more or less rare. Specimens weighing eighty pounds have

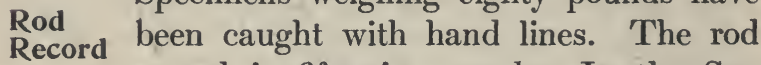
record is fifty-six pounds. In the San Francisco market, bass weighing sixty to eighty pounds are not uncommon, and doubtless the fish attains a maximum weight of one hundred or more pounds.

In the Gulf of California a larger species of this genus is found; it is a stouter and bulkier fish; there is a record of one being caught weighing
Bass 172 pounds. It is known as the Gulf bass and can be found in vast numbers on the shores of the East coast, even entering the mouth of the Colorado River.

\section{STRIPED BASS}

No one will question or dispute that the striped bass, or rock fish, is the finest representative of the whole great family of sea-basses. Handsome in form and color, its table qualities are excellent, and it is a bold and persistent fighter in whatever method caught. It is a prolific breeder, hardy, and easily transplanted for distribution.

The natural range of the striped bass includes the entire Atlantic Coast, from the Gulf of Mexico to the Gulf of St. Lawrence, the fish entering rivers and ascending them almost to their head-waters. 


\section{Popular Salt=Water Game Fish}

Individuals are known to have been taken every year in the Alabama River, Lower Mississippi, in the vicinity of Pensacola, Florida, Natural Dis= in the great bays and sounds from
tribution

North Carolina to Cape Cod. Large numbers are caught in Albemarle. Sound, at Edenton, North Carolina, and near Norfolk, Virginia. In the Potomac River the fish ascends to the Great Falls. It is one of the most highly esteemed fish of the Delaware and Susquehanna rivers. The Jersey and New England coast are the centre of their abundance. Large numbers are caught by lines and by seines. The striped Artificial
Distribution bass ascends the St. Lawrence as far as Quebec. It was introduced into California in 1879 and 1882, and has now become so abundant that the annual catch by fishermen is nearly as large as the yearly supply on the Atlantic Coảst.

Russian River, in Sonoma County, Cal., seems to be the Northern limit, while Monterey Bay is the Southern boundary, but in 1903 more were planted in the vicinity of San Diego Bay, and later arrangements were also made to send bass to Del Norte County, where the waters are considered suitable for the experiment. The most favorable haunts of the Pacific Coast are Lake Merritt in Oakland, California, San Francisco Bay, San Leandro Bay, and San Antonio Slough; the last is celebrated for its great numbers of big fish.

The striped bass prefers cold waters. It is fre. quently found at the mouths of small creeks and 


\section{Fish and Fishing}

in tide ways, where it lies in wait for the great schools of little fish upon which it feeds. The rock-bound shores of our Northern bays furnish hiding places for fish of the larger size. Sometimes a school of big ones will be seen in the surf along sandy shores feeding upon small fish which may be present. Edenton and Weldon, Favorite North Carolina, and Norfolk, Virginia,
Haunts are noted fishing places. The Roanoke

River, near Hamilton, yields many bass. The Little Falls of the Potomac is a favorite ground for fly fishing. The Passaic and Raritan rivers have furnished good sport; also the Great South Bay, Newport, Rhode Island, Block Island, West Island, No Man's Land, and Martha's Vineyard. The striped bass is especially fond of rivers frequented by shad, because the eggs of that fish furnish one of its favorite foods, and the river herring which accompanies the shad also contributes greatly to the diet of the bass.

The bass is carnivorous and predaceous, and consumes vast numbers of little fish in streams, particularly herring and shad. The shallow bays along the coast furnish it with killifish, anchovies, silversides, lant, and many other small fishes as well as worms, shrimps, crabs, squid, clams, scalFeeding lops, mussels, and other marine invertebrates. Its movements while feeding are greatly influenced by the tides. The uncertainty of the movements of this fish is proverbial; it is hard to find at certain times, and still more difficult to bring to the hook. It is shy and ex- 


\section{Popular Salt=Water Game Fish}

tremely wise on occasion, so that no angler can lay claim to continual success. When the bass does strike the hook, there is no mistake about its intention, for it hooks itself without assistance.

Quick to seize the lure, it holds it firmly, full of resources in its struggle against capture, endowed with wonderful strength and endurance, quick to take advantage of natural obstructions; the striped bass as a game fish may be classed with the salmon, for its intelligence and fighting quali-

As a

Game Fish ties. Its first plunge, when hooked, is more powerful than that of the salmon, and its endurance is greater. The most expert angler finds it utilizing every accessory which nature has furnished for its protection; sharp rocks are used to the best advantage to cut the line or break the hook.

Casting through the surf is one of the most exhilarating, though precarious, methods of bass fishing; everything combines to circumvent the fisherman; the bass itself, the weight of the surf, Outfit the undertow, friction of the rocks, all test his skill to the utmost. As the season for striped-bass fishing is long, and continues far into cold and inclement weather, the angler must be supplied with warm clothing, including waterproof jacket, mitts, and boots, a soft cap, overalls, and thumb stall for protection against friction of the line.

As the fish vary greatly in size, and styles of fishing differ widely, there is a variety of rods. A casting rod should be eight and one-half feet long 


\section{Fish and Fishing}

and weigh eighteen ounces, of split bamboo preferred, but one of lancewood or greenheart will stand hard usage better. The chief qualities required in a rod for sea fishing are toughness, spring, Rods and elasticity. It should be silk wound and have guides and tips of agate or carnelian. For bait casting a light rod about nine feet will be suitable for fishing in shallow bays, near river mouths, or in streams within tide limits. For fly fishing a good black-bass rod will prove efficient. For still fishing, where fish are small, one may have fine sport with a plain rod, combined with a float and sinker, with two hooks on gut leaders.

There is just the same variation in reels. Surf fishing demands a reel holding 300 yards of Reels 12 to 18 thread Cuttyhunk line, and must be a quadruple multiplier. It will cost from $\$ 10$ to $\$ 15$. In fly fishing the same tackle that is used for black bass will do for striped bass.

The lines generally used for surf fishing are linen Cuttyhunk, from 9 to 18 thread, in length varying with the character of the fishing. For still fishing in summer, or bait fishing from shore, the line is Line usually of braided linen, smaller size, in lengths of fifty yards, with three-foot leader of single gut. In trolling for small fish up to ten pounds, about one hundred feet of braided linen, size $\mathbf{E}$ or $\mathbf{F}$, or two hundred feet of size $\mathbf{E}$ for larger bass may be used.

For small bass up to three pounds weight, No. 1 or 2 sprout hooks on gut snells will be found suit- 


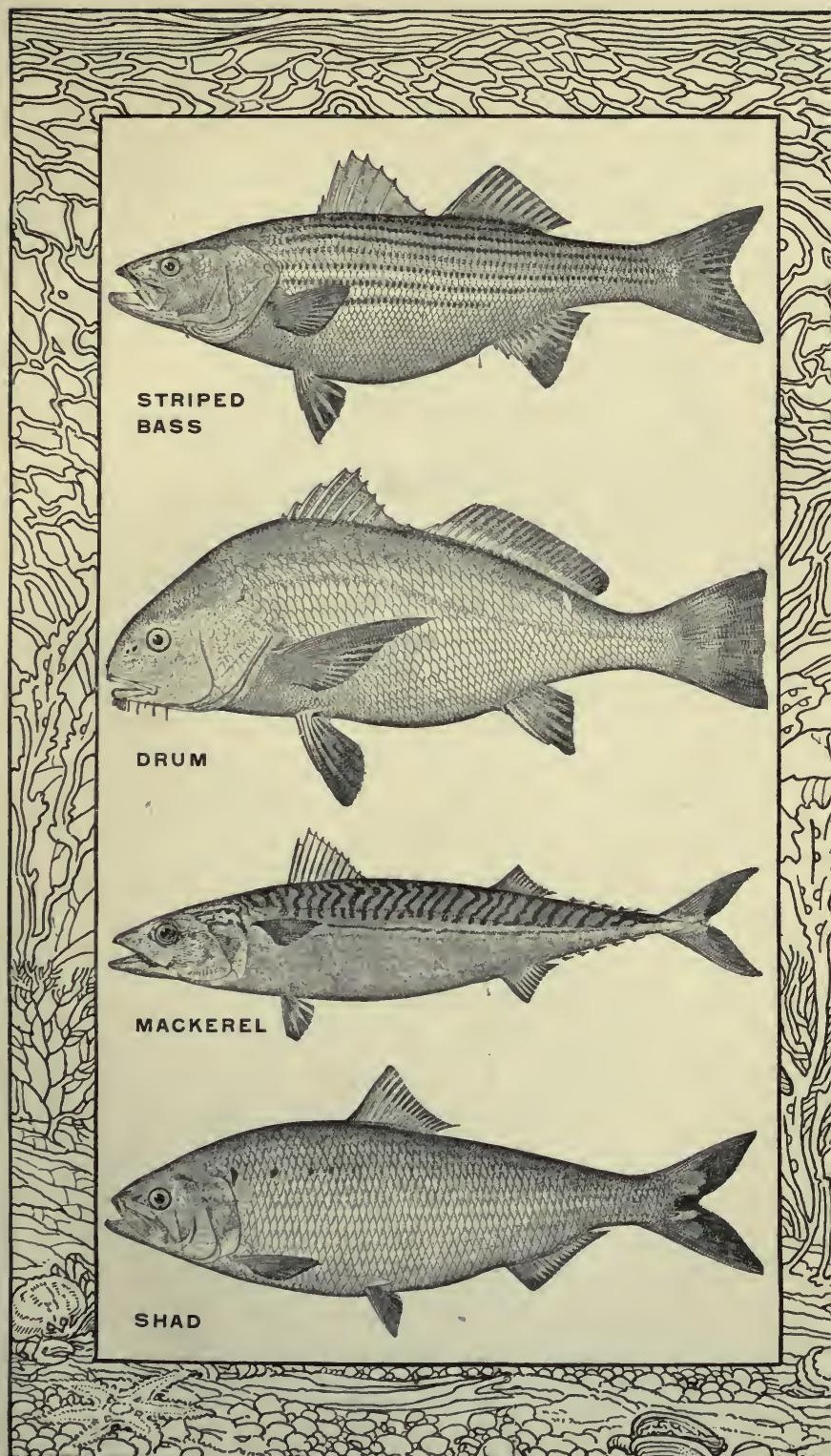





\section{Popular Salt=Water Game Fish}

able; in trolling, sprout hooks No. $2 / 0$ to $3 / 0$ on gut snells, for small fish, and No. 5/0 to $6 / 0$ for larger bass. The best hooks for surf fishing on the coast are knobbed sprout hooks No. 5/0 Hooks to $8 / 0$. These are to be secured to the line by two half hitches with an additional half hitch to attach the loose end. The outfit is better with two twisted three-foot leaders; one attached to the line with a brass swivel, the second fastened in like manner to the first; and linked to the end of this, also by means of a swivel, a small spinner; to the end of the spinner a hook should be attached, usually a $4 / 0$ or $5 / 0$.

The striped bass is such an omnivorous feeder that many different kinds of bait are required Bait during the season, but the favorites are small eel, shrimp, crab, and worm. In California little fish called shiners and sardines and the clams of the region, form the bill of fare. They also troll with the Golcher, Stewart, or Wilson spoon.

For the Eastern coast, especially in localities near New York, the shedder crab and lady crab are frequently employed. The sand worm and blood worm make tempting bait in trolling or still fishing. Two or three worms are threaded through the whole length of the body and must cover the hook entirely from point to snell.

The skimmer clam is known as an excellent bait at Allenhurst, N. J., where a great bed of these clams attracts bass of large size. Small fish of many kinds, either alive or dead, are always attractive; 


\section{Fish and Fishing}

spearing, killifish, lant, smelt, mullet, eel, alewife, and menhaden, the latter being most famous for surf fishing. On certain rivers, eel-tail is used; another bait seldom heard of at present, but formerly much used, is shad roe. Artificial lures for Flies trolling include the bone, or block-tin squid, spoons, spinners, and their allies, attached to a single hook. Artificial flies are available for striped-bass fishing in fresh or brackish water only, and are best in the spring when the bass are ascending fresh water. The best fishing is at sundown. Showy flies are the favorites, red ibis, bluejay, oriole, royal coachman, polka, silver doctor, Parmachenee Belle. Trolling the fly is best, with plenty of line, and working the line at the surface, sinking it a foot or two, and then jerking it.

Casting in the surf, with menhaden bait, is regarded as the highest type of expert angling for striped bass on the Atlantic Coast. Most complete outfits are provided by the tackle Casting in dealers, according to the taste and
the Surf means of the angler. Skilled anglers cast a distance of 120 yards, though the average is much less. In making the cast, the line is reeled up to two feet from the tip, one hand grasping the rod above the reel, the other below it; the thumb of the lower hand on the thumb stall controls the line so that it travels the same rate as the bait. The motion of casting is peculiar and requires long practice. The cast may be made with either hand, the body being turned to one side or the other as occasion requires. The one great essen- 


\section{Popular Salt=Water Game Fish}

tial is to deliver the bait at the surface of the water without a jerk, and the motion of the reel must stop as soon as the bait touches the water. As soon as the bait sinks to the bottom, the Surf line is reeled in slowly, and casting is continued till the fish is hooked. The first dash of the fish is the most critical stage of the fishing, and the bass may sometimes rush toward the angler faster than the slack can be taken up, calling for the best judgment and skill on the part of the angler. The preparation and application of the menhaden bait is very simple. The fish is first scaled, then a slice is cut from each side from head to tail, leaving little except the back bone, head, and fins, which are utilized later for "chum." The hook is inserted in the fleshy side of a strip, then returned through the edges of the scaly side in such a manner as entirely to conceal the shank; the bait must be tied on the hook, or it will be soon washed off by the action of the water. After two baits are cut from the sides, the remainder of the fish is chopped up and thrown into the water, the solid portions sinking at greater or less distance from the shore, while the oil covers the surface for a considerable space.

In landing a large fish through the surf, great skill is required, for many tricks are played by the bass to evade capture.

Other relatives of the striped bass are the white bass, yellow bass, and white perch; though much smaller and of lesser importance, they are still caught on tackle of a lighter build. 


\section{Fish and Fishing}

\section{BLUE-FISH}

Fishing for blue-fish in a spanking breeze, with not too much sea on, is one of the most invigName and orating and stirring pastimes in the Distribu= whole range of angling sport. The tion blasé, lazy man, fond of a good meal, should try this sport to earn it. Full of life and thrills, a large blue-fish will convey that feeling through the line to the angler in a marked degree.

This fish on the coast of New England and the Middle Atlantic States, is called the blue-fish; it is also known in Rhode Island as the horse mackerel, south of Cape Hatteras, as the skip jack, in Virginia and Maryland as the Greenfish." Young blue-fish are called snapping mackerel or snappers. In the Gulf of Mexico, the name of blue-fish is in general use.

This fish is widely distributed in the Malay Archipelago, Australia, and at the Cape of Good Hope, at Natal, and about Madagascar, at Malta, along the coast of Syria and the Canaries. It has never been seen on the Atlantic Coast of Europe, or in the waters of Bermuda or Western Islands. On our coast it ranges from Central Brazil and the Guianas through the Gulf of Mexico and North to Nova Scotia. From Cape Florida to Penobscot Bay blue-fish are abundant at all seasons when the temperature of the water is propitious. It is possible that the presence of their favorite food, 


\section{Popular Salt=Water Game Fish}

the menhaden, has as much influence upon their movements as water temperature.

The blue-fish sometimes make their way up the rivers to a considerable distance, the adults, however, apparently never entering the perfectly fresh water. They are found in the Potomac as far North as Acquia Creek. The young of the year are taken as high as Sing Sing on the Hudson, and in other tidal rivers where the water is entirely fresh. The blue-fish is carnivorous, feeding solely upon Feeding ather fish; indeed, it may be rightly called
Habits a "veritable animated chopping machine." There is no parallel in point of destructiveness to the blue-fish among the marine species on our coast the business of which is to cut to pieces and otherwise destroy as many fish as possible in a given space of time. Going in large schools in pursuit of fish, not much inferior in size to themselves, they move along like a pack of hungry wolves, destroying everything before them; their trail is marked by fragments of fish and by the stain of blood in the sea, because where the fish is too large to be swallowed entire, the hinder portions will be bitten off and the anterior part allowed to float away or sink. It is even maintained that such is the gluttony of the fish that, when the stomach becomes full, the contents are disgorged and it is again filled. The youngest fish, equally with the older, perform this function of destruction, and, though they occasionally devour crabs, worms, etc., the bulk of their food is derived from other fish. The rate of growth 


\section{Fish and Fishing}

is evidence of the immense amount of food they must consume. A fish of five pounds in the Weight spring will have increased to fifteen pounds in the autumn. They have been known to attain a weight of twenty-five pounds, the average being from eight to twelve. A bluefish weighing one pound measures about fourteen inches; two pounds, seventeen inches; three pounds twenty-one inches, and eight pounds, twentynine inches.

Two methods are employed in angling for this fish; the favorite mode is by trolling or squidding, the other by heaving and hauling in the surf; both have plenty of excitement as well as considerable hard work, especially with large fish.

In trolling at the surface a squid of bone or metal is used, or live bait, menhaden, or any silvery fish, or an eel skin drawn inside out. It is necessary that the boat or launch should go at Trolling a lively gait, - and the blue-fish will follow after to bite. The fish will not bite unless the bait is speeding along through the water. Trolling is now done mostly from a gasoline launch; the old style sailboat hardly suffices, and can be used only under certain conditions; and the difficulty of luffing at the right moment makes it not nearly so easy as the ready launch that is stopped and reversed almost immediately. From such a craft, from one to a dozen lines are let out at varying distances, though the fewer lines out the better and safer the chances are of landing fish. No one can deny the 


\section{Popular Salt=Water Game Fish}

fascination of the sport, the fresh wind, the rushing boat, with the silvery bait flashing from wave to wave sixty or more feet behind. Soon the smashing rush of the fish literally tears away line despite every effort to save it, and the angler lies down holding on for dear life, his arms wrenched and chafed by the gamy fish, full to the very end of vigor and irrepressible animation. Strong Line The tackle, therefore, must be very stout and able to resist such tugging. The lines should be 300 feet of strong Cuttyhunk, No. 15 to 18 , with a sprout hook, 5/0, snelled with wire. If the fish are running large, a larger hook should be used.

Heaving and hauling, as its name implies, is when the angler, standing on the beach or in the breakers, whirls his heavy gig about his head, and casts in far into the sea. No rod is used, the work being done by hand throw, the hands Heaving protected by stout woollen gloves. HavHauling ing hooked the fish, he puts the line over his shoulder, walks up the beach, dragging his prize after him to the shore. This practice is only possible on exposed sandy beaches, like the Jersey shore, Montauk, and other places. This method of fishing requires much practice. Three important things govern the use of this tackle, $i . e$, the squid must be heaved far enough to straighten, maybe, one hundred yards of line, and the line must run out freely and smoothly; also the hand-over-hand recovery must start so soon as the squid has touched the water. The prowling 


\section{Fish and Fishing}

blues feed outside the surf, hence the squid should strike the water well beyond that point. The heavy squid plays the part of sinker, and the way it will carry out a line from a skilled hand is a wonder to behold. The amateur squidder frequently makes fast the home end of the line about his waist, neatly coiling the line up on the sand. Experts term this "lubberly," and hold the coils in one hand, a thing which no novice should attempt. For the heave, a right-handed Way to expert holds the line in that hand, at a
Heave point which he prefers above the squid which is started slowly swinging around his head; when nicely going, the speed is increased till the whirling tackle fairly whistles; then at precisely the right instant the final heave is given, the squid hums seaward like an arrow, the line hisses after, and when everything is as it should be, the squid plunges into the water ahead of an almost straight line.

To pull a fighting blue-fish through the surf is no easy matter, and for this vigorous sport the Best Costume best costume is an old bathing suit; and, as the feet have to take a tight grip on the sand as well as shells, old yachting or tennis shoes will be preferable to the naked feet.

In both trolling and squidding, the blue-fish generally hooks himself. In every instance the main thing is to keep a taut line, yet never to hold so fast that the fish can smash the tackle, which he will do in the fierce rushes if checked too hard. It makes a "smashing fight" from the minute it is 


\section{Popular Salt=Water Game Fish}

hooked, till its death, and it is impossible to tell which way it will run. If it runs in so fast as to get the line slack it will either shake the hook Fighting out of its jaws, or swim ahead of the wire
Traits leader and bite the line off with its keen teeth. It exhibits the courage, strength, and deviltry of a wild tiger, running deep, breaking water, rushing from side to side, always pulling and jerking with its entire energy. When bluefish are not sighted "chumming" is resorted to to lure them; the oil from the cut-up menhaden floats upon the surface and so attracts them.

For rod fishing from a stationary skiff, near where blue-fish are breaking, use a light trout rod for the smaller fish, and a heavy bass rod for the larger fish; on such tackle blue-fish are Rod Fishing very gamy, frequently leaping from the water, making every effort to smash all in sight. The most reliable bait are lobster-tail, shedder crab, chopped moss-bunker, live killies, herring, and spearing.

The young blue-fish or snapper, from six to ten inches long, is fished for by a host of anglers, because it is good sport on a light rod, and when caught, excellent pan fish. The fishing is entirely on the surface; the best hook is the longshanked Carlisle, size from No. 4 to 1 , as sometimes the angler will encounter a school of small snappers, and again get into a school of one or two-pound fish. Early in the morning is the best time for snappers; they are caught mostly in inlets, bays, or behind bars. When one fish is 


\section{Fish and Fishing}

caught, it is certain others are near by. Every angler has his views as to the best baits; spearing is the favorite; live killies are excelFishing lent, and cut-up snappers. Fish three feet below the surface and keep the bait moving about; if necessary use a small sinker. Snappers bite vigorously, and for that reason a fine gimp snell should be attached to the hook; the line should be fine, but of good strength, for small and young as this fish is, like its parent, it shows remarkable agility and holding power.

\section{BONITO AND ALBACORE}

The habits of the bonito are similar to those of the blue-fish, though it is, if possible, even more active and more the embodiment of perpetual and insatiable hunger. They come and leave the coast at the same time, they prey in company upon menhaden and mackerel, and together they are often caught. The two kinds of fish do not mingle, but the regiments rush to battle side by side. The bonito is known as the skip jack, Spanish mackerel, etc., and reaches a length of thirty inches and a weight of ten or twelve pounds. It inhabits the Atlantic Ocean, on both coasts, and is common in the Mediterranean. It occurs in the summer between Cape May and Cape Sable, off Cape Hatteras, off Block Island, Long Island, mouth of the Chesapeake, and so down to the Gulf.

Schools of bonito cause more commotion in 


\section{Popular Salt=Water Game Fish}

the water than those of the blue-fish; they spring above the surface and are visible at a long distance; they are attended by the same schools of screaming gulls and terns, and leave in their track similar "slicks" of oil and blood.

The bonito is caught on the surface of deep water in the open ocean by exactly similar bait and tackle to that used for the blue-fish; its play is much the same and its resistance quite as strong. Its flesh may be ranked among the many excellent food fishes of our coast, and is a worthy rival of the Spanish mackerel and the sheepshead.

On the Pacific Coast, the albacore is considered an understudy of the tuna, which it much resembles, both in activity and agility, often seizing the bait intended for tuna. It is one of the commonest fishes of the Pacific waters, found in nearly all tropical seas, but not caught on the Atlantic Coast, and rarely seen. It grows up to a weight of sixty-five pounds; the adult fish, while it is caught near the island shores, never approaches the mainland, being found from two to five miles out. Always present in vast numbers, feeding and leaping from the water, it is a constant menace to the small fish. The rush of the school of albacores, as they charge the flying fishes, invariably arouses the angling community. The commercial catch is large and important in all the sea-shore towns from San Diego to Santa Cruz. As sport, all find it a paying employment, and go from five to seven miles out to sea, 


\section{Fish and Fishing}

from San Diego, Coronado, San Pedro, Long Beach, Redondo, Santa Barbara, and all along shore.

The typical equipment is a rod of greenheart, noib-wood, or split bamboo, to weigh about twentysix ounces, as the fish often sulks, and has to be "pumped." 'The rod should be in one piece, with a short butt, having extra large tips for albacore and tuna: The rod has double bell guides so that the line can be changed every day and the rod will not curve in any given direction. The reel should be lashed to the rod and be of me. dium size, to hold 300 feet of wet No. 15 Cuttyhunk line, though some anglers use tuna tackle, owing to the chances of hooking one at any time. A short phosphor-bronzed leader and an $8 / 0$ O'Shaughnessy hook. Trolling at full speed, the albacore can be taken with a bone gig. With a slower gait, live bait, sardines or smelt are the common lure. The hook is inserted in the mouth, brought out at the gills, the point turned and thrust into the belly of the bait, near the vent. When pulled straight it is almost concealed. The mouth is closed with a wire, fastened to the shank of the hook, or thread may be used. Each leader or snell should have two or three swivels; no sinker is required. The launch is manned with a gaffer who acts .as engineer, and has the same duties as in tuna fishing. The albacore is a fierce fighter for its size, more so even than the tuna. 


\section{Popular Salt=Water Game Fish}

\section{CHANNEL BASS}

The channel bass is one of the largest food fishes of the Southern waters, reaching a length of five feet and a weight of seventy-five pounds. It inhabits the Atlantic Coast from New York to Texas, is abundant in the Carolinas, Florida, and the Gulf of Mexico, and is also taken at times on the New Jersey coast. It has many titles. At the mouth of the James River it is called the drum, at the mouth of the St. Mary's, Ga., the red bass, at Fort Marion, Florida, the Various spotted bass, on the Indian River the red
Names horse, at Tampa the reef bass, New Orleans the poisson rouge, San Antonio the pez colorado. But the common name is red drum, or channel bass. It is caught on the bottom of the ocean and in the surf from July to late October. It is a splendid fighter especially if reasonable tackle is used, springing forward and down with long sweeps, shooting back and forth, cutting the water with splendid rushes.

In fishing the surf the usual stiff casting rod is employed, and the method used is similar to that with the striped bass. In bays and mouths of rivers an eight-foot greenheart or bamboo rod weighing twenty-four ounces is used, the line a No. 12 Cuttyhunk, and hook about the size of a No. 7/0 Limerick, baited with mullet or crab; a sinker should be attached to the line with the usual swivels, as the channel bass is a bottom feeder, 


\section{Fish and Fishing}

and often caught weighing fifty pounds along the Florida coast. This locality is also famous Tackle for large sharks, strikes from this same being about two to one for channel bass. On the Jersey coast the bait used is clams, oysters, or menhaden, the latter preferred. The greater part of the fishing, however, is done with hand lines, the fisherman heaving a heavy sinker, with the menhaden bait tied securely to the hook, far out over the rollers, and the fish is hauled in through the waves.

In south Barnegat Bay, at Harvey Cedars, some of the finest fishing can be had at times, especially in September, the catches ranging from fifteen to fifty pounds. As a game fish, the channel bass is similar to the striped bass. It lives upon Habits crustaceans, mollusks, and sea worms, and has been seen to root up and tear the weeds in shallow waters in its search for food. This explains its presence along the line of surf in the shallow waters of the great sandy beaches of the coast, the home of numerous burrowing crustaceans. Another species, called the black sea drum is a bottom feeder, and is caught Black in the surf with skimmer clams, and soft
Drum clams, baited on heavy tackle, similar to that used in surf casting for striped bass. It is caught on the New Jersey shore, particularly at Anglesea, in the spring and summer; sometimes, though rarely, farther North. It is most abundant in the Gulf of Mexico and the Southern Atlantic coasts, and is caught weighing up to seventy-five pounds. 


\section{SHEEPSHEAD}

This powerful fish is common, and ranges all along the coast from Cape Cod to Mexico; at Old Point Comfort, Va., the sheepshead appears in April or March and leaves in October. On the Florida reef, at Garden Key, it can be caught all the year round, but more frequently in summer. Distribution All down the Florida coast, it is a common winter fish; the Indian River region down to Biscayne Bay, is a favorite locality. The oyster beds of the Chesapeake are a favorite locality for sheepshead, and there are numerous fishing grounds about New York Bay, well known to boatmen, at Staten Island, Fort Hamilton, on the New Jersey shore, Jamaica Bay, Fire Island, South Bay, and various other localities.

The sheepshead reaches a length of thirty inches and a weight of twenty pounds, though the average is about ten. It is one of the most Weight valuable of our food fishes and some anglers prize it for its strength and game qualities. It is a slow-swimming fish, frequenting rocky shores in shallow water, piers, and old wrecks, the latter particularly being favorite resorts; and wherever a wreck can be located on the Atlanic Coast, good sheepshead fishing may be assured. Its head is large and its body deep, and it has a large powerful tail; the mouth is large, and provided with a curious array of teeth, those in front being conical or incisory for tearing or 


\section{Fish and Fishing}

biting. Back of these are others, in two or three rows, which are crushers or grinders. These are Food suggestive of the habits of the sheepshead, which is equipped by nature to live upon shells and crustaceans, and wherever found, it feeds upon young oysters, barnacles, cockles, and crabs of various kinds. With the front teeth it wrenches shells from rocks or piers and passes them to the grinders where they are crushed. It is Tackle caught on all kinds of tackle, but the most popular is the same as that used for the tautog, which it resembles in many ways. The rod is a short, medium casting rod for the ocean, with strong line, and large wooden reel; for inside bays, an eight-ounce bait rod, linen line, stout single leader, multiplying reel, a swivel sinker attached to the line and a No. 2 sprout hook. The best baits are oysters, clams, and crabs. In baiting the hook with a small crab, it should be done so that the point of the hook passes through from the belly through the back, taking great care not to crush the body in hooking. If the hook is put through nearer the head, it will last much longer. The best time is during flood tide and the first and last of the ebb tide. When Striking the fish takes the bait it should be struck sharply, but not too soon-not till a second or third tug is felt, The time to strike is when it has the bait well in toward the crushers. After striking, when the hook is secure, give the fish line, for the first few dashes are most severe on the tackle, especially with a weighty fish. 


\section{CHAPTER III}

\section{Popular Bottom Fresh=Water Fish}

\section{PIKE PERCH}

The wall-eye pike, as an angler's trophy, may be placed between the perch and the pickerel; for all-round fishing it hardly reaches the pickerel in gameness, though to some anglers it is superior. Personally, I would rather play a perch of similar size, than the wall-eye. It is essentially a bottom fish, and the bait it goes for best is minnowsand lob worms, and occasionally it rises to a fly. Owing to its nocturnal habits, the best time to angle for it is from sunset to dark; in fact, it is fished for after dark by many people on moonlight nights, Nocturnal Habits or by the aid of a bright lantern. The wall-eye is known by many names, for it is abundant all over the Continent, and is still being regularly distributed as a desirable fish, both for its game and eatable qualities. In various localities it is known as the glass-eye pike, blue pike, yellow pike, salmon, or jack salmon. In Canada, where it grows to a weight of twelve pounds, it is called the doré. In shape and coloration it is similar to the perch, 


\section{Fish and Fishing}

but has a larger mouth and very sharp teeth. Its eyes are also very large and glassy, being more prominent than most fish, well fitting it for seeking its prey by night. The wall-eye is found in all depths of water, but prefers to stay at the bottom, either of rock or of gravel, in clear as well as cold water.

It loves to lie in deep pools, at the foot of ripples, or where the current is strong and deep, near small dams and under sunken logs, or shelving rocks and banks. It will only enter shallow water in lakes and streams in search of Wound food, or at spawning time. It feeds on every kind of small fish and does not spare its offspring. Insects, larvæ, crawfish, and worms are devoured in great numbers, and even small frogs aad young snakes are preyed upon. Its usual weight is from two to four.pounds, but it grows to fifteen pounds under favorable conditions. Its flesh is highly prized as a food fish, being white, firm, and flaky; which makes it a commercial fish of much importance, especially on Lake Erie, whence it is shipped in large numbers. There are three ways to fish for the wall-eye; on lakes it should be fished for in comparatively deep water, over pebbly bottoms, with a live minnow or crawfish, particularly minnows with silver sides, such as dace, roach or red fin; in rapid currents, pieces of fish with the skin, bright and silvery, trimmed in a shape so that it will spin nicely. I have caught them on a spinner with a bright-colored bass fly at the end. But, 


\section{Popular Bottom Fresh=Water Fish}

certainly, the best sport is with the fly at evening on running streams. The most likely method is casting over deep and swift water at Mode of the foot of rapids, when there is a brisk
Capture wind blowing. In such places they congregate in search of minnows that are rendered helpless by the churning waters. For lake fishing, the rod should be stout, with a strong silk or Cuttyhunk line; the hook snelled with gimp or piano wire, because, like the pickerel, their sharp teeth easily cut through the stoutest gut. Drop down a sinker to find the proper depth to adjust the float-three or four shot placed on the snell to keep the minnow down in deep water. More fish are caught on dull, cloudy, windy days and in the evenings. In minnow fishing, if the fish run to a good size, use No. 2/0 to 3/0 hooks. When a wall-eye takes the bait, it swims leisurely away, sometimes taking the float along without going under the water; let it go some distance, then raise the tip of the rod quickly, and it will be hooked. If it does stop after moving a short distance, then strike good and hard; after being hooked it will tug violently and keep up the game till reeled in. It never runs, but simply pulls and tugs till landed.

The large, heavy fish often dive to the bottom after being reeled nearly in; there they stay, jiggering, and it requires careful work to move them. They will only rise to the fly at evening, and that not often, but much more readily in white, foaming water, below a dam or falls; 


\section{Fish and Fishing}

though this fish is most uncertain to locate, being much given to roaming about in search of food.

In fishing rapids, let the fly wander at will, just as the current takes it; sometimes the fish darts for it at the surface, at other times when sunk three feet by the force of the water. One fly is sufficient at the end of a six-foot leader, similar to that used for bass; the fly being about the size of a small bass, or large trout fly. In color use dark flies for mornings, dark gray hackle, Fishing black hackle, gray drake. For evening, use a white miller, silver doctor, or coachman. As soon as the fly is taken, keep a firm hold on the rod. The wall-eye is every bit as strong as the bass, and while it lasts, in swift water, a ten-pound fish is no mean work for a tyro to tackle. Dr. Brown Goode states, "There is no better pike-perch fishing in the world than that which may be had in the vicinity of Lake City, Minnesota, in Lake Pepin, and the adjacent waters."

The wall-eye is quite common in most of the rivers and lakes of New York, New Jersey, and Pennsylvania, and it seems to thrive well wherever it is placed.

\section{DACE AND CHUB}

This bright, silvery little fish is very abundant, and delights in rapid, rocky portions of large streams and in the deeper channels of the clear running brooks. It is one of the largest of the min- 


\section{Popular Bottom Fresh=Water Fish}

now family, reaching a length of eighteen inches, and about two pounds in weight. It is extremely common in the Delaware River and its tributaries, and is moderately abundant in the Susquehanna. Both in shape and movement it is not unlike the brook trout, with which it lives in amiable relations, although it will live in water of a much higher temperature than the trout; still, it prefers cold and rapid streams. Like other common and familiar fishes, it is called by many names in different localities, some of which are: silver chub, cousin trout, roach, the corporal, and many others. When half grown it is netted and used extensively as bait, being hardy, bright, and silvery in color. Trout anglers have no liking for it, because it constantly rises and takes the fly intended for more desirable fish. In smaller rivers, like the Beaverkill, it is so numerous that twenty dace will rise to one trout, but they often rise short, getting just pricked on the lips, so that they are very often whipped off in recasting the fly. I have caught them on every possible bait; they will take a small artificial or live mouse, a silver minnow, helgramite, or small frog; but for all-round fishing they give more play on the artificial fly, or live worm. In running water, the regular trout tackle is best suited to dace Taken on fishing, a light nine-foot rod, oil-silk
the Fly line, with a six-foot leader and small, easy-running, click reel. For worm fishing, the hook should be No. 9 to 11 ; no leader, sinkers, 


\section{Fish and Fishing}

or float are necessary, as dace are always looking to the surface for passing food. The fish, on seeing it, darts quickly above from below, and takes it with surprising quickness. The mouth of the dace is not large like that of perch, eel, or catfish, so that at times it misses taking the hook, but often manages to take the worm. On being hooked, it fights desperately for a time, running back and forth in rapid succession; sometimes, though rarely, it will rise above the surface. When a fish is hooked that measures over twelve inches in length, it should be gently led to the shore; and played over the pebbles, or sand, from out of the water; if a net is not handy, do not attempt to lift a large dace bodily from the water; a small hand net is indispensable; small fish can be lifted to be unhooked, and basketed. They are so plentiful, and bite so vigorously, that the basket is easily filled, and in place of trout they make, so far as game is concerned, a very fair substitute. They take bait at all times and seasons, and are equally voracious with the artificial fly, so long as it is small in size; all flies are alike to them, though the black gnat is taken most often. It matters not where the cast is made, in the centre of the stream or at the sides, they dart for it. I

had quite a large one playing some Playing time, and was quite sure it was a trout, till it gave a leap from the water nearly two feet high. Much to my surprise I found it to be an unusually gamy dace. This was in very rapid deep water. In pond or lake fishing 


\section{Popular Bottom Fresh=Water Fish}

for dace, with worms, exactly the same method and tackle should be used as in fishing for sunfish, but in quiet water their actions are not nearly so gamy in resisting capture, nor do they grow so large, if the same water contains the ravenous pike or bass. Another species, called the red fin or golden shiner, is often caught on the fly and on the worm.

The chub is a very leathery-mouthed and hardy fish. It is coarser and more bony, but very much handsomer in form and color. Much stouter tackle is required when angling for chub than for the dace. The chub, in some waters, grows to the weight of five or six pounds. On bright days, a fly is the best method of catching this fish, and good sport may be had from an anchored boat by throwing the fly just under the bushes which overhang the banks of the stream, Chub as it is characteristic of this fish to lie under trees and bushes, waiting for insects which drop from them. A good method of angling for chub is to hook a live grasshopper through the shoulders and draw the bait along the surface, and then gradually get under, the water. Chub are extremely shy, and the angler should keep out of sight as much as possible. Chub will take minnows and worms. For such bait, fish either with a float or without a float; sinkers should be attached to place the bait on the bottom; then move it slowly along.

When a chub is hooked, give it plenty of line, for it shoots violently away in a few seconds, but 


\section{Fish and Fishing}

soon gives up the fight. The chub is not held in any great esteem as food for the table, its flesh being very coarse and hard.

\section{CARP}

The carp is a native of Asia, and was introduced into America in 1831; its acclimation has been wonderfully successful, especially in the

First

Introduced South, where it continues to grow throughout the year, and sometimes attains a remarkable size. It is a favorite of thousands of modest fresh-water anglers whose pleasure lies in quiet, peaceful delight, in the midst of restful scenery of the woods and meadows. The carp is a handsome fish, with scales large in size and of a golden bronze color. There are numerous species of this family. The Varieties mirrow, or king carp, is named on aclarge scales, which run along the body in three or four rows, the rest of the body being bare. The leather carp has on its back either only a few scales or none at all, and possesses a thick, soft skin which feels velvety to the touch. Then there is a golden carp, popular in small ponds and household aquariums. The common carp has become very abundant in certain lakes and rivers; those found in the latter are much the best for the angler and are of better flavor.

It prefers a muddy bottom, feeding principally on vegetable food, the seeds of water-lilies, wild 



\section{Popular Bottom Fresh=Water Fish}

rice, and water oats. In captivity it will eat lettuce, cabbage, soaked barley, wheat, rice, corn,

Habits insects and their larvæ, worms, and meats of various kinds. They can readily be caught with dough, grains of wheat, worms, maggots, and sometimes pieces of meat or fish. The carp is very tenacious of life, more so than any other fresh-water fish, with the exception of the catfish and eel. To insure the best sport when angling for carp requires great preparation and care. The line should be entirely of mediumsized round gut, clouded gut preferred, and a very light porcupine quill float, with one goodsized shot, placed about six inches from the hook, which should be a No. 5 or 6 . Bait it with a red worm, which should rest exactly on the bottom. The night before fishing a quantity of ground bait, composed of bread, kneaded into little balls, should be thrown in the place. Early Method of in the morning, or late in the evening, Fishing is much the best time for carp fishing, and the all-important thing is to keep out of sight, as the carp is very shy and will not touch the bait if it sees the angler. A forked stick can be put in the bank for the rod to rest on while the angler moves back out of sight, where he can lie down and so watch the float. Do not strike for some time after the float goes under; wait till it moves away, then strike hard, as the carp has a tough mouth and there is little chance of losing it. Carp fishing is a difficult and uncertain operation, especially if the fish are large; they are 


\section{Fish and Fishing}

very shy and wary and patient; staying around for some time before they touch the bait.

Young carp, of two pounds or less, take the bait easier, and sometimes large ones will not be taken at all; some anglers, while fishing, throw worms into the water to get them near the bait; there is no fear of overfeeding as their appetite is unlimited. The carp is noow rapidly coming into demand as a market fish; from the Illinois River alone, over six million pounds are taken annuShy'ness ally. New York City consumes over seven million pounds yearly. Big fish are taken in large numbers from the lakes Erie, Chautauqua and Ontario, and from these waters are fairly good eating; but if taken from small stagnant ponds, they are both tough and of a very peculiar muddy taste. When hooked they pull pretty hard, but make no fight. Their excessive shyness makes angling for them much more interesting sport than it would otherwise be.

\section{SUNFISH}

The little sunfish is one of hardiest and prettiest species of the fresh-water fish. North and South, wherever clear water is to be found, this little favorite is ready at all times to gratify the eager young angler. In the South it is known as the bream or brim; in other localities as the sunfish, pond fish, tobacco box or pumpkin seed, which it is supposed to resemble. The sunfish grows to a length of eight inches and a weight of half a 


\section{Popular Bottom Fresh=Water Fish}

pound. In coloration it rivals the gayly tinted fishes of the coral reefs in tropical seas. It is well armed with a fierce array of spines, Various and shows a temper, especially after
Names nest building, unusual in small-sized fishes; consequently they thrive and multiply almost beyond belief in ponds and streams too small for bass, and too warm for trout. It prefers clear and still water, living in and about weeds and grasses. Sunfish are gamy and eager biters, and earthworms are their delight; they will rise readily to a very small artificial fly, with a vim and dash much in the manner of the black bass, their bold and larger cousins. Like the perch, any old tackle will catch them at times, but if proper angling oufit is used, larger fish, and more gamy fish are caught.

A.regular eight-foot bamboo rod should be used, not too pliable or too stiff; such a rod covers the wants of all fresh-water bottom-living fish, but the Tackle "sunny" needs finer tackle than the perch. The size of hooks should be from 8 to 10 , and the float should be small, for the fish takes the bait with such a snap, running away at a clipping pace, keeping the float on the move all the time. Adjust the float so that the bait hangs a foot from the bottom. Place two or three No. 8 split shots about six inches apart from the Bait snell, to sink the bait. Have the worms small and of a pinkish color, putting only one worm on the hook, and be very careful to loop it over the shank, leaving a small end to wig- 


\section{Fish and Fishing}

gle in the water. In fishing for sunnies, there is little advantage in moving from place to place-if the fish stop biting, throw a few worms in the water to attract them to the bait, as sunfish shoal together in large numbers; throw the bait in gently without much splash.

The outfit for fly fishing is similar to that of brook trout, but two flies are sufficient on a threefoot leader; use the smallest of flies. They should be cast on the surface of the water, as the fish dart up from below to seize them. The best flies are black gnat, gray or brown palmer, and the coachman, but any flies will do, if they Mode of are of the smallest possible size. As Capture the sunfish has a particularly hard and bony mouth, it may not be hooked firm, often being held by a thin skin; so that it will be safer if a small hand net be provided. In fishing a stream, cast the fly down a runway, and let it go into quiet water, for sunfish choose to lie in still places; wherever the force of the water takes the fly it will turn off and circle around the sunny's hiding place. In such runways, a worm is just as effective, indeed more so, because nature is imitated exactly.

Another good fishing ground is near the shores of large lakes; throw the line in between the weeds in open places - the float will keep the line from getting entangled. The best time for fishing 'is from sunset to dark. A nice string of a dozen sunfish, weighing a half pound each, makes a very agreeable and palatable dish, if fried in hot 


\section{Popular Bottom Fresh=Water Fish}

fat, sharp and crisp. They are better eating than perch, but not so sweet or flaky as the bass.

\section{PERCH}

Yellow perch, also known as ring perch, striped perch, and raccoon perch, are among the most strikingly marked and best known Name and fresh-water fishes. They are found
Locality from Nova Scotia to North Carolina in coastwise waters, and are very abundant in large ponds, lakes, and many of the streams.

They are ready biters, strong and voracious feeders, and can be caught on any bait: minnows, worms, crickets, grasshoppers, small frogs, crawfish, and small spoons. They will rise to an artificial fly, and will ravenously take one of the brightly colored fins of their own species, if placed on a hook and skittered quickly over the surface. Perch frequent quiet waters of moderate depth, pools under hollow rocks, eddies and shady reaches in the meadow brooks, creeks, and canals, preferring the sides of the streams to the swift currents, and sandy and pebbly rather than muddy bottoms. In mill ponds they are likely to be found in deep waters just above the dam. They sometimes descend into brackish water, where they become large and very firm-fleshed. In muddy pools they often assume a golden color, but are soft of flesh and not well flavored. They love to be among long weeds, grasses, and lilypads in large lakes, and seem to thrive in neigh- 


\section{Fish and Fishing}

borly friendship with the bass, pike, and pickerel. Their strong array of sharp spines probably protects them from those savage and predaceous fishes. They are gregarious, and always in schools, Habits each school about a uniform size, whether large or small. When the young angler meets a school of large perch, he may capture every one if he be noiseless and wary. The usual length of the yellow perch is less than ten inches, and its average weight less than a pound, though specimens have been caught up to four pounds. The simplest way to catch perch is with the boy's standard outfit: a pole, stout line, large float, and heavy sinker, with a

Mode of Capture worm or minnow for bait. This, however, is only effective when the water is muddy and the perch numerous and hungry. For wary, large fish, in clear water, more delicate tackle is necessary. The line should be fine, of enamelled silk, a fly rod of six ounces, a light click reel, and a small three-foot leader, with two flies on No. 7 hooks. The yellow perch is just as good fishing as speckled trout, size for size, eager to rise, bold to a degree, and it fights to a finish. For worm or minnow fishing, the float should be small and well balanced, shot for sinkers, only heavy enough to keep the float steady. Suspend the bait a foot from the bottom, moving it up and down in a gentle manner. No. 5 or 6 hooks on snells, with a small swivel to connect the line, may be used. Always have live worms either placed to touch the bottom, or two 


\section{Popular Bottom Fresh=Water Fish}

feet from bottom in running water, so that they drift back and forth. This method applies to grasshoppers and crickets, with No. 5 to No. 3 hooks. Grasshoppers should be hooked through the shoulders; both they and crickets will live for some time if hooked in that way. Hook small minnows through the lips, the point coming out on tip of nose. When the fish strikes, take plenty of time, so that it can gorge the bait; only strike after it has moved away: It should be struck with a sharp move of the wrist, not a savage pull or. long jerk. A perch makes two or three runs up to the surface and down; give it a chance, and let it play.

Trolling or casting with small single-hook spoon or live minnow without spoon, will invariably capture large perch in lakes and ponds. The boat should be rowed along the side of weed beds, exactly in the manner of fishing for pickerel. In fishing for perch the angler cannot be too careful in unhooking these spike-armed With the heroes. In fly fishing for perch the best time is when the water is gently rippled, or from sundown to dark; and in casting, it is well to let the fly sink about a foot and jerk it sharply through the water. Any trout or bass fly tied on No. 5 to No. 3 hook is effective. I have caught perch on brown palmer, coachman, and silver doctor.

In the fall perch become more wary, especially the large ones. When perch are caught in stagnant pools and muddy lakes, before cooking them 


\section{Fish and Fishing}

it is best to take the skin off; by so doing, the muddy taste is avoided. When caught in running water or cool spring-fed lakes, it is only necessary to take off the scales; for game or edible purposes, choose, when possible, a running stream to fish in.

\section{EELS}

The common eel is another bottom fish that is caught extensively by hand lines, at evening and night time, because it is nocturnal in its habits, sleeping or lying in the mud Fish Night during the day. It is a most voracious feeder, devouring great quantities of the fry of other fishes. Nothing in the shape of living things comes amiss to an eel; everything that/lives in the water it will prey upon. They are very powerful and rapid swimmers, and on light tackle give good sport. Eels have been known to grow to a length of four feet, but the average is two feet. They breed in salt water; both the adults and the young ascend the streams from the sea a distance of 500 miles. They are often found in the long grass of shallow, running streams. In such conditions they are more difficult to catch, and more agreeable to eat. The best way to angle for eels is to drop the Mode of bait in some sandy or muddy bottom,
Capture always near long grass or weeds. Use a strong, light rod, without reel, and have the line tied at the tip; or if the angler wishes to play it with the reel in the usual way, considerable 


\section{Popular Bottom Fresh=Water Fish}

sport may be had, because the fish wiggles in all kinds of holes, and no amount of tugging will loosen him; for that reason both line and gut leader should be stout and strong. A float may be attached to the line to keep the bait out of and between weed patches. Use No. 7 or 8 hooks, baited with a small red worm, which Bait should be allowed to drag and lie at the bottom. Worms, if alive, are more attractive to eels than anything else, both in pond and river fishing. The eel requires considerable indulgence when it takes the bait; as soon as it is pulled out of the water, stamp the foot across its body, holding the line tight with one hand and with the other cutting through its gills with a sharp knife, taking care not to cut the gut snell which is always some distance down its throat. This is the most humane and quickest method to prevent the slippery rascal from tying the line full of knots, and very often breaking the line and so getting away. Good eel fishing is best near dams and mill wheels. To one sitting on the bank at evening, properly prepared with bait and tackle, and a small lantern, this fish provides quite a diversion. Eel fishing in salt water is also very

Salt=water Eels popular when it is done from a boat, which should be anchored near the edge of channels on soft and sandy, or muddy bottoms. Use a simple, stout hand line with a strong leader and heavy sinker, to keep the bait on the bottom. Eels will not rise from the bottom for their food, so it is necessary to 


\section{Fish and Fishing}

attach the hooks quite close to the sinker and two or three hooks may be used, preferably No. 8 to $\mathbf{1 0}$ sprout.

By far the best bait in salt water is the shedder crab, but sand worms, killies, clams, or even pieces of fish will take them. Many anglers use a long-shanked hook, which is more convenient to hold the fish from wiggling, and makes it easier to take the fish from the hook.

When the fish bites, strike hard, and if hooked, lose no time in bringing it up over the side of the boat. After it is boated, get a good tight grip on the body, with the help of the line; then slap the tail smartly on the edge of the boat, stunning the fish. Then take out the hook. Another species of eel is called the conger-eel; it sometimes grows to a weight of thirty pounds. It is a savage brute, with long jaws lined with As Food sharp teeth, and it snaps viciously at everything in sight. The best way to kill it is to rap it sharply on the head with a stout stick or piece of iron. The eels are all very palatable eating, especially those caught in clear, running water; the flavor is sweet, and the flesh nutritious. If well cooked, either boiled, fried, or stewed, or even pickled and salted, they make a savory dish.

\section{THE CATFISH OR BULL-HEAD}

The right name of this popular and well-known fish is the horned pout, and it is of a wide distribu- 


\section{Popular Bottom Fresh=Water Fish}

tion, being found in ponds, lakes, and streams all over the United States and Canada. It multiplies so rapidly in any kind of water that it soon clears out all edible matter which would be useful food for better fish. This species reaches a maximum length of eighteen inches and a weight of four pounds, but the average size of market speci-

Distribution and Species

mens is much smaller. There are many species of this family, each rejoicing in a number of names, the largest kind being the lake catfish, which is sometimes caught in the Mississippi River weighing over one hundred pounds. In Lake Erie, specimens have been taken up to fifty pounds. The United States Bureau of Fisheries propagates and distributes the most valuable members of the family, the channel catfish, spotted cat, yellow cat, black cat, marbled cat, blue cat, black bull-head, and the pout. They are all dull, slow-moving fish, but when hooked are surprisingly lively.

The catfish are a hardy race, and are very tenacious of life, opening and shutting their mouths half an hour after their heads have been severed, and so prolific that, in some places, the water seems a living mass of fish. When the mature fish grow to a large size they feed on the young of their own species if their food is scarce. Habits Many instances are recorded where a small fish having been hooked, a larger fish has taken it and swallowed it, and so got caught. The catfish retains its freshness much longer than any other fish, and it has compara- 


\section{Fish and Fishing}

tively few bones. Some writers consider it the most unattractive fish of our fresh waters, and to catch it represents the lowest depths of depravity in fishing with hook and line.

The catfish is a ready and voracious feeder, any kind of bait being greedily swallowed, and a large fish, when it feels the hook, goes for some distance at astonishing speed, pulling and tugging with bull-like strength. In angling for them, the worm is the most convenient bait. They will take minnows, grasshoppers, small frogs, a piece of salt mackerel or salt pork, as well as pieces of fresh fish cut from the under part of chub, perch, or sunfish; as the catfish always gorges the bait, the hook is easier to extract if it is a good size.

No. 5 or 6 Limerick hooks will do. Use a light ten-foot rod of native cane, with a line of twisted silk tied to the tip of the same length as the rod.

Tackle

No reel is required. A three-foot leader, like the one used for perch, makes the line stand up in the water, and a float is also an advantage; it keeps the line from floating toward the angler, and is easier to cast among the weeds. Two hooks can be tied, one touching the bottom, baited with dead fish or pork; the other, six inches above, on which is placed a worm; they soon go for the bait, if the fish are plentiful, and the float goes under surface. The fish is sure Mode of to be fast, and there is no need to hurry;
Capture when it is pulled ashore or in the boat, take care how it is handled, as the horns on its fins make nasty wounds. The hook will be far down 


\section{Popular Bottom Fresh=Water Fish}

the throat; the best way to extract it is to slit open the stomach to the gills. Never lift the fish bodily from the water, for the reason, as often happens, that bass and trout may have taken the bait, and by that means get lost. There is no special time to fish, any time will do, though the hot months of July and August are best. To properly skin them, the head should be cut from below, leaving the skin attached to the shoulders. By placing a small pinch of salt on the fingers, a tighter grip on the skin will enable you easily to pull it from the body. The fish can then be cleaned and afterward placed in salt water-extra salt if the fish is taken from stagnant water; after being in salt water a few hours, they can be sharply and quickly fried in hot fat. If cooked without being skinned they are quite disagreeable in taste. 


\section{CHAPTER IV}

\section{Popular Bottom Sea Fish}

\section{SEA-BASS}

This fish has an enormous appetite, and is well known to be a most determined and persistent biter. Its range is from north of

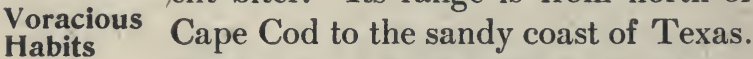
Round about New York, Long Island, and New Jersey it is plentiful and common.

During the breeding season the male develops a large hump on its shoulders, which takes away the fine shapely appearance which distinguishes the female. It has a large powerful mouth, and will take a generous bait of almost anything that is eatable. It spends its time nosing about loose stones, in cavities of rocks that have seaweed growing upon them, where they get various crabs, fishes, and other creatures, in water from twenty to fifty feet deep. They are a bottom-feeding fish and rarely come to the surface. The best time to catch them is during their feeding time, which is during the lull of the waters between the turn of the tides. The largest fish are caught on the fishing banks, where steamers, 


\section{Popular Bottom Sea Fish}

during the greater part of the year, make daily trips-to the Cholera Banks, off Sandy Hook and Long Branch, where they are caught Where weighing from four to eight pounds. Those caught in the bays, estuaries and back waters are much smaller, weighing half a pound to two pounds. The best place to angle for them is in deep channels, holes under sedgy banks, and over wrecks, or on bottoms where the black mussel is found. They will take bait from Decoration Day to October, but the larger-sized fish are taken in inside waters from September to October. Like the fresh-water bass, it will sometimes break water, but not until drawn near the boat, when suddenly it makes a vicious leap, shaking its solid body in all sorts of wriggling and muscular contortions; from the moment the hook gets in its leathery jaws, it makes a steady fight and dies hard, considering its size. Almost any bait is suitable, skimmer Bait clams, mossbunkers, shedder crabs, live killies, pieces of clam, sand worms, shrimps, and cut menhaden; all of these, it will take with avidity, for the sea-bass is always on the feed.

The tackle used should be a good, stout rod, multiplying reel, and a strong line of generous

Tackle length. Leaders are only necessary when fishing for the big, yellow autumn bass, which are very shy and wary. Late in the season, use a No. 2 sprout hook or Carlisle. A heavy sinker is required, to hold firmly on the bottom, and the hooks should be tied quite close to the 


\section{Fish and Fishing}

sinker. Some use only one hook, others use two, each having on a different bait. In baiting with shrimps, place two or three together on the same hook, for this fish is one of the few that go for the largest bait and, as his mouth is so ample, he is sure to be well hooked with a big bait. At the turn of the tide the angler is sure to be busy for the short time it lasts. The feeding ground extends along the coast from Delaware to Maine, wherever the sea-weed grows from beds of mussels. It is eminently a coast fish, seldom venturing far above the bays and back waters; as a food fish, the meat of the sea-bass is excellent; as a game fish it may be placed next in rank to its cousin the striped bass. The sea-bass is known in various places as the blackfish, black Will, black Harvey hannahills, blue-fish, rock bass, black bass, and by many other titles.

\section{TAUTOG OR BLACKFISH}

The tautog is one of the species of parrot fishes, stockily built, with hard scales, and harder mouth; it is slippery as an eel, and salt-water anglers like to fish for it because of its strength and hard fighting. Although not a large fish, only averaging two to three pounds, individuals weighing ten and even fourteen pounds are by no means unusual. The largest tautog on record was obtained near New York and weighed nearly twenty-three pounds. It is found in greater and lesser abundance from St. Johns to Charleston, S. C., and is 


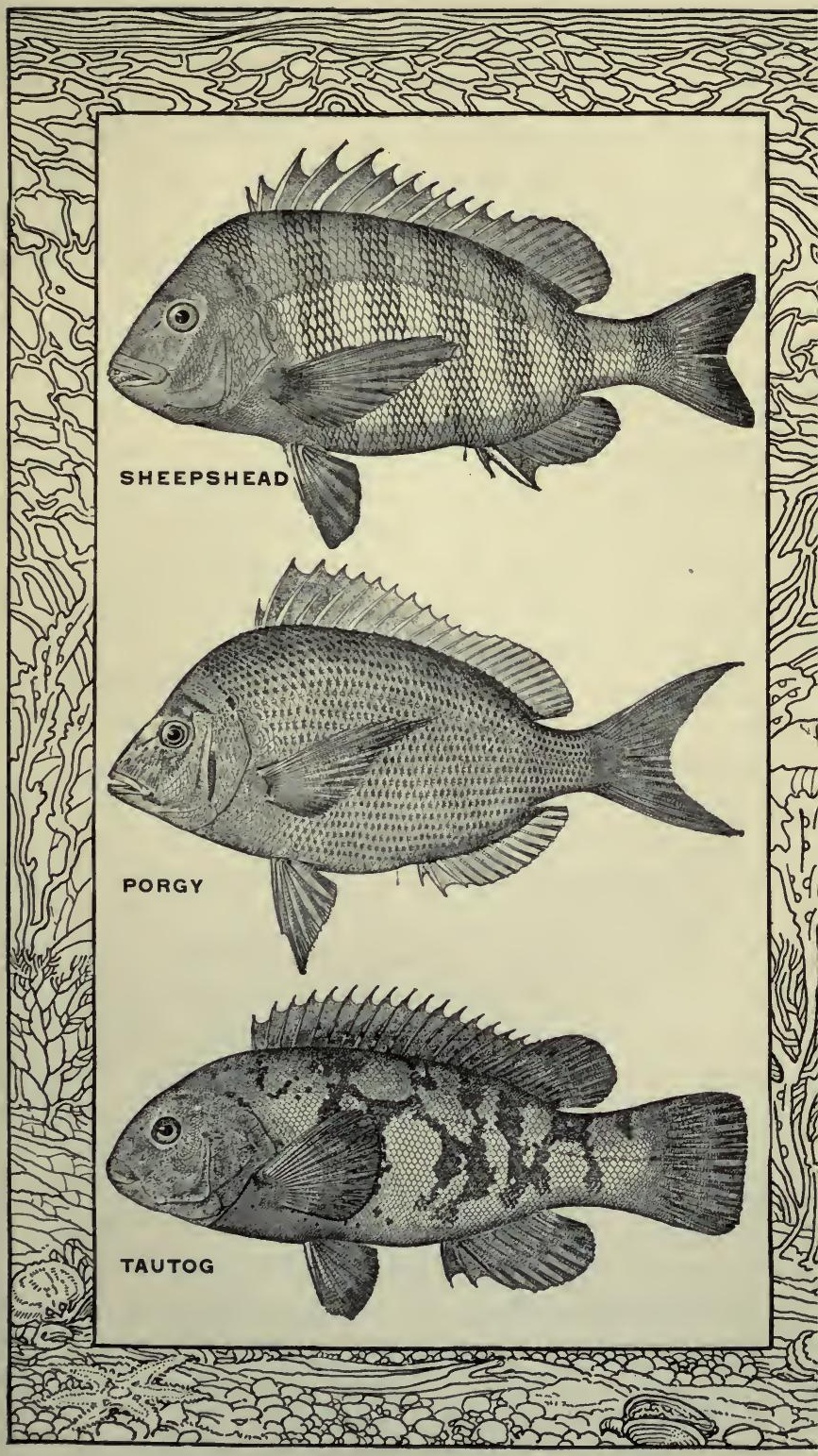





\section{Popular Bottom Sea Fish}

known in various places as blackfish, tautog, chub, moll, Will gorge, and oyster fish. East of

New York it is usually called tautog, Various

Names

a name given to it by the Narragansett

Indians. As may be inferred from its

haunts and the character of its strong, sharp teeth, the tautog's food consists of hard-shelled mollusks, squids, scallops, barnacles, and sand dollars; many of the mollusks they swallow, shells and all, ejecting the hard parts after the flesh has been digested. Angling from the rocks for the tautog is a favorite pursuit all along Where the coast, particularly about New York, where there are precipitous shores, on which the fishermen stand. On Long Island Sound and other protected waters they are usually fished for from boats anchored among the reefs, or near wrecked vessels, and shell-covered piles and wharfs; rocky bottoms are very good places. At some places they bite best on the flood tide: in others they are voracious during the ebb tide. Some anglers bait for them by throwing overboard broken clams or crabs to induce them to renew their visit. In April and May we have the best angling; though they frequent local waters all through the summer, not many are caught in the hot months until fishing begins again in October and November. The best bait Fall Fishing in the spring is the clam, preferably soft-shell clam, for at this time, many anglers say, the tautog has a tender mouth. In the fall, both lobsters and crabs, as well as fiddler and 


\section{Fish and Fishing}

rock crabs, are the favorite bait; sometimes they will take shrimp and sand worms.

Large numbers of tautog are caught by the anglers who go out daily on the fishing steamers in the open sea. All, or nearly all, use the regulation salt-water tackle: a short, stout and heavy rod, strong line, and large wooden reel. Such tackle is necessary for outside fishing, and the hook should be very strong but not large in size. For inside fishing lighter tackle will do-the hooks the same. In baiting the hook with a small crab it should be done in the same manner

Mode of Baiting as for sheepshead, viz., the point passed through the beilly to the back near the head. A shrimp should be hooked by placing the point near the tail, underneath, afterward drawing the shrimp over; by such a method it will live longer. The sinker should be a heavy one, and the two hooks should be tied about six inches apart, as near the sinker as possible. No leader is required, but the gut snells must be very strong to withstand the sharp teeth when the fish is tugging at the bottom. When fishing inside waters, arrange so that the boat can be anchored near the edge of the tide, close to a rapid current, where the reefs or rocks are about twenty or thirty feet deep.

The tautog is supplied with a pair of strong crushers, situated in the back part of its mouth, and consisting of two flat groups of ball-shaped teeth between which they crush small shell-fish before swallowing. When it takes the bait it 


\section{Popular Bottom' Sea Fish}

pasises it on to the crushers, when a peculiar succession of bites is felt by the angler, who loses How many a fine fish by being too hasty to is Taken hook it. After the first indication is felt of a fish taking the bait, it should be struck sharply. The tautog bites like a sheepshead, but with less power. It is an adept at getting hooks or sinkers fast in the clefts, for as soon as it bites and feels the barb it darts under or between rocks, leaving the angler thankful if the fish liberates the hook or sinker at the price of freedom.

\section{THE KINGFISH}

The kingfish is perhaps the gamest for its size of bottom feeders that inhabit salt water. All anglers have the the best opinion of it, and with one accord, after it is landed exclaim, "What a dandy!" Its gamy qualities, its beauty of color Description and form, as well as its excellent flavor, caused the loyal citizens of New York in Colonial days to call this species the kingfish. In former times when they were much more abundant in New York Bay, the kingfish and small striped bass were the crowning glory of old-time anglers. The kingfish is also known as the hake on the coast of New Jersey and Delaware, as the tomcod on the coast of Connecticut, the barb, and black mullet in the Chesapeake, the sea mink in North Carolina, and sometimes also in the South as the whiting. 


\section{Fish and Fishing}

It appears quite early in the spring with the weakfish, and is found a good deal in company

Where

with it; like that fish it seems to prefer a Caught

light mixture of fresh water, as is shown

by its keeping in the mouth of rivers and running farther up during the dry season. It takes the bait quite readily, though it is not caught in anything like the same number in a given time as the weakfish, thirty or forty at a single tide being considered a splendid catch for one boat. They bite readily at hard or soft clams or small pieces of fish and are taken most successfully on the early flood tide. They may be captured on or near oyster beds, especially when the oysters are being taken up. Its mouth though small is hard and leathery, and when once hooked it is sure to be fast; however much it fights' it rarely gets off. In taking the bait they have a variety of ways in going for it, sometimes with just a nibble that is hardly felt; at others they rush at it with the greatest fury, racing off with long runs from right to left, sometimes going at a clipping pace right around the boat; in this way the gamy fighter keeps it up till safely landed, when the Gaminess angler will be surprised at the determined resistance a fish of but two pounds can and does make. Though I have never seen it, it is said at times to break water if the line is held taut, playing exactly like, the small-mouth bass, with rushes to the bottom, and pulling and tugging in angry jerks. The proper tackle for so bold a fish is a light pliant 


\section{Popular Bottom Sea Fish}

rod and multiplying reel, ${ }^{-a}$ strong line of linen, measuring at least fifty yards, a swivel sinker with a three-foot leader. There should be two hooks, sprout or Aberdeen preferred, size No. 1 to 3 .

The best bait is shedder crabs or sand worms; also shrimps, blood worms, and clams are effective. In August, the kingfish can be

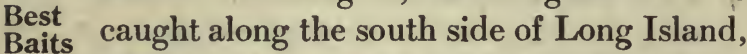
off the Jersey coast, at Atlantic City, Long Branch, and Barnegat Inlet. Farther South they are yet more numerous. In size, this fish varies from one to six pounds; the average being two. In surf fishing, the best time is the first of the flood tide; in this situation, with plenty of room, the kingfish is seen at its best, swiftly swimming long distances near the bottom; after a very long run, it stops to jigger and shake, finally breaking water fifty to one hundred yards from the rod, if sufficient line is given it; and one will wonder after landing a fish which has taken half an hour to kill, that it weighs scarcely three pounds. The angler is sure of one point in his favor, for certainly no bottom-loving fish plays such a game for the angler's real delight. The cook, as well as the epicure, will be fully assured of another, that no fish that swims the sea makes a better dish.

\section{PLÁICE}

No seafish is so popular or so well known as this; it is called by a variety of names, which are 


\section{Fish and Fishing}

often confounded with other species. In some localities it is called plaice, summer flounder or turbot flounder; whereas the flounder is known as the flatfish, winter flounder, mud-dab and nigger fish. The two can be easily distinguished by the plaice having a large mouth, and the flounder a very small one. Next to the halibut, the plaice is the most important and valuable flatfish on the Eastern coast. It averages in size from two to eight pounds, though specimens have been caught up to twenty-five pounds. It corresponds with two highly prized, but somewhat rare fish caught on the English coast, krown as the turbot and the brill. Like others of their species, the plaice habitually lie upon the bottom, where their peculiar shape and color protect them from observation, and also give them an excellent opportunity to capture their prey. They are found mostly Habitat in bays, where the bottom is muddy and grassy, and in shoal water, along sandy reaches of the coast and bays. Plaice may be taken from the early part of June till October. In Florida they are taken throughout the year, most pentifully in the summer months. They feed on small fish, shrimps, crabs, squid, and are frequently seen at the surface of the water, rapidly swimming and even jumping above the surface in pursuit of sand eels and sand smelts. Favorite fishing grounds are on sandy bottoms at a depth of eight or ten fathoms, or in channels near the sides, and they can be taken either from a boat at anchor, or one that drifts slowly along 


\section{Popular Bottom Sea Fish}

with the tide. The method is to fish with one hook six inches from the bottom, and another hook two feet above it, tied on a strong threefoot leader; use a sinker just heavy enough to hold to the bottom, with live killies for bait, though herring, spearing, and mossbunker will do; if no live bait is available small strips of snapper, or porgy, cut in the shape of a fish will often be a taking bait. Hook the killie by inserting the point into the back, near the dorsal fin; then pass it along under the skin toward the tail as far as the bend of the hook will permit; then, again push it through the skin to clear the barb.

Drifting is the method for fluke. When the bait rig is out, and is being trailed along, its dis-

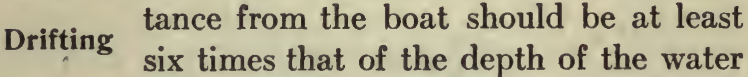
where fishing. When still fishing the killie can swim about as if entirely free. The most successful rig for local waters is a leader four feet long, fastened a few inches above the sinker, a No. 5/0 Kirby-Limerick hook tied to the end of the leader, and another a foot from it. In drifting, the long eel grass and sea-weed will collect on the line, leaving the bait on and near the end of the long leader clear. In using these long leaders, do not allow the lead to go to the bottom too fast, because the leader will go down parallel with the line and become entangled. Use heavy sinkers according to the thickness of the line. When the fish takes the bait, the strike should be followed up with a 


\section{Fish and Fishing}

gentle jerk of sufficient force to embed the hook firmly and to rouse the fish into action.

The advantages of fishing for plaice are these: they can be fished for at any time of day or night;

Night and Day Fishing no waiting for tides and certain kinds of weather; they are hungry all the time, and always willing to take what is offered to them. They have a rugged and powerful mode of resistance, especially the larger fish, which often succeed in getting off the hook or breaking the tackle, for they fight all the way till taken from the water.

If cooked when fresh they are exceeding good eating, the flesh being white, juicy, and of good flavor. When filleted they make an excellent substitute for the famous English sole.

\section{FLOUNDER}

Next in importance to the plaice is the flounder, sometimes called the winter flounder, and also the flatfish; it is much more abundant and does not grow to so large a size as the plaice.

The flounder is a cold-weather fish, biting from February to the beginning of May, and again Cold from October to December. They are Weather always on the bottom, feeding on shells, Fishing young crabs, or whatever they can find among the stones and in the mud. They prefer soft, black mud bottoms, and the boat should be anchored half-way between the middle of the channel and the edges. At high tide they scatter 


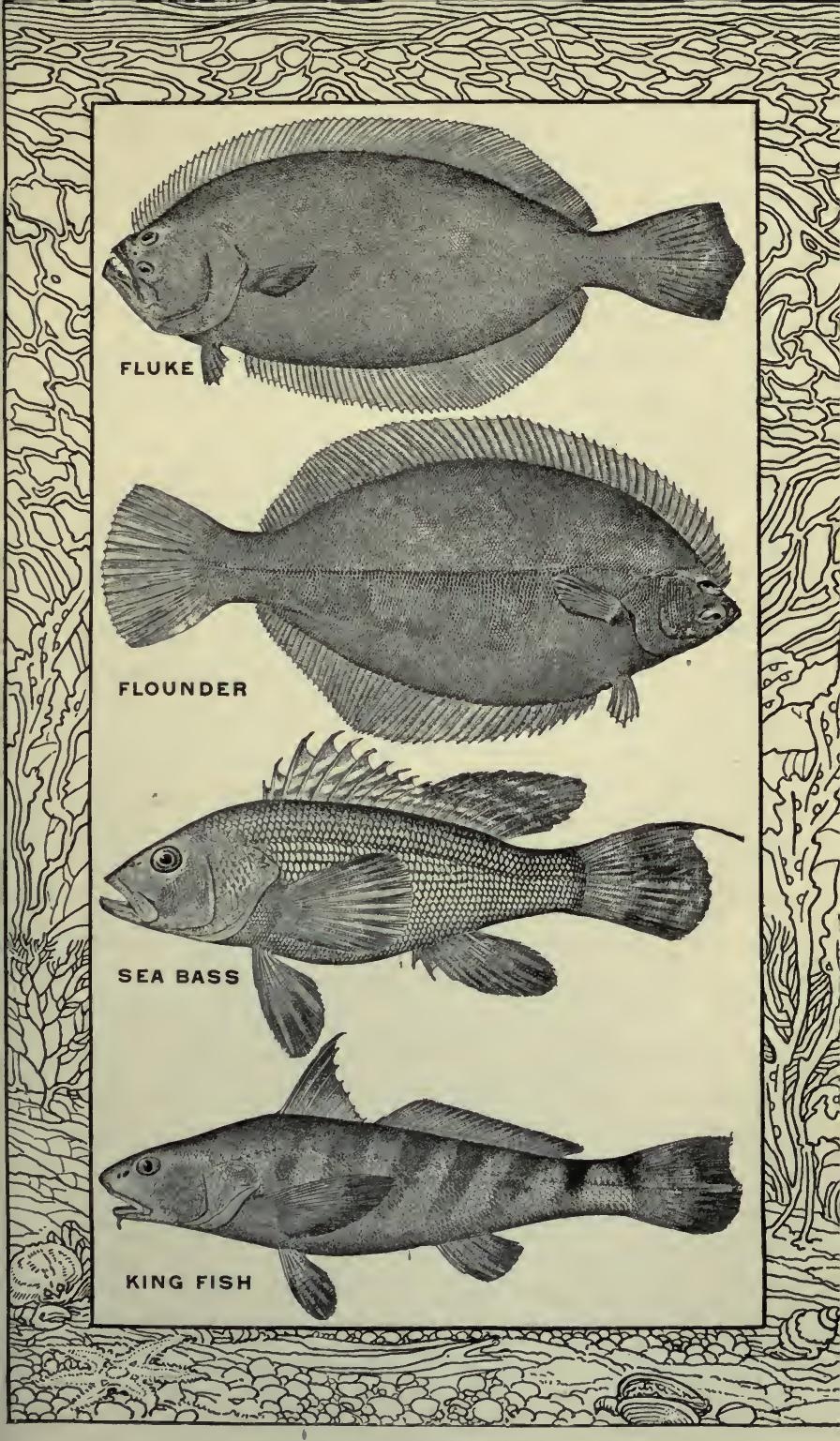

POPULAR BOTTOM SEA FISH 



\section{Popular Bottom Sea Fish}

well over the flats; at low tide they gather together in the centre of channels. Their mouths are very small, and as they would be unable to seize and kill other fish, they never come to the surface in search of their prey, as do the large-mouthed plaice.

If the angler does not succeed in getting bites, it often happens that the fish lie buried in the mud, so that if the bottom is raked with the anchor or with the oar it will often stir them up to take the bait; and if the sinker is a heavy one and gets embedded, move it around to stir up

Use Small Hooks the bottom. The hooks should be small, and placed within a few inches of the sinker. The best baits are sand worms, clams, and mussels.

There is very little sport in landing flounders, because they rarely attain a weight of over two pounds, but they make up in numbers what they lack in weight, and the angler more often than not fills his basket with this toothsome little fish. If fried when fresh, they are equal to any saltwater fish in sweetness and nutriment.

The rod is of little service in flounder fishing. Hand lines are invariably the rule; just a simple line, snelled hook, and sinker. No leader is required. Two or three hooks may be attached if the fish are plentiful, and it is not uncommon $\begin{array}{ll}\text { Fish Muddy } & \text { for three fish to be hauled in at } \\ \text { Bottoms } & \text { once. All the hooks should, how- }\end{array}$ ever, be as near the sinker and the bottom as possible; for that reason a small wire spreader can be attached whereby the three 109 


\section{Fish and Fishing}

hooks can be tied, all of even length from the wire, about six inches, the same distance as the sinker. Like the plaice, they are ever ready to bite at all times during the day or night, and wind and tide play no part in the success of their capture.

\section{LAFAYETTE}

The name Lafayette was given this fish by the New York fishermen in consequence of its reappearance in large numbers in that region having been coincident with the arrival of Lafayette in this country in 1824. It had been known before that time, but only in scattering numbers. Dr. Tarleton Bean says that the name "spot" is derived from the presence of a dark blotch, about as big as the eye, near the root of the pectoral fin.

Other names of this species are: goody, old wife, roach, and chub. The spot swarms on the Eastern coast during the hot months Various Names of July and August, and is caught as late as September. It is a small fish, rarely exceeding ten inches in length or a pound in weight; but for its size it is game to the last, and puts up a fight to shame much larger fish. It is one of the best pan fish caught in the sea. In both these qualities it resembles the porgy, though as a fighter it is much superior. It ascends small streams in rather blackish water, and is a common associate with the white perch. 


\section{Popular Bottom Sea Fish}

Immediately the Lafayettes are running, it is a signal for hundreds of men and boys to crowd Popularity the North River piers so thick that on some occasions there is little elbow room for comfort, and when these fish come in with the new flood tide in large numbers, catches of a hundred or more are not remarkable. They may also be caught in great numbers at Rockaway, on the Jersey shore, Cape May, Atlantic City, and as far down as Mayport in Florida. The most successful baits are small pieces of clam or small-sized sand worms. At certain times they are Baits erratic and will only take shrimp or the leg do well to supply himself with a variety of bait. All bottom feeders are good biters at night, and the Lafayette is no exception to this rule. They take the hook with a sly, tentative nibble, sometimes hardly felt by the angler; but on feeling the barb, away they go, darting off, back and forth, with remarkably bold breaks similar to those made by brook trout.

The main point in catching Lafayettes is to have small, very sharp hooks attached to the Sharp leader about six inches from the sinker, which should be heavy enough to hold on the bottom. In such places as the docks and piers the tide does not affect the water, but when the tide runs heavy the sinker can be changed. The bait should be small, just enough to cover the barb. A large bait tempts them to nibble away small pieces without being caught. Hand lines are 


\section{Fish and Fishing}

more frequently used, but a short light rod is more handy and easier to handle, and lands the fish more quickly, either in fishing from a boat or dock. Some anglers use a heavy sinker and swing it overhead fifty feet away. After getting the line taut, wait for the bite of a large fish. As the fish swims near the bottom in great schools, three or four hooks can be used and more fish caught. From late in August till the end of September

Time to Fish there is hardly a place where Lafayettes may not be found, and if the right bait is given them, good sport, and what is more, a good mess can be caught.

\section{P̄ORGY}

This is another plentiful and common sea fish known by many names. In New England it is generally called scup, while about New York it is paugy or porgy, both being abbreviated from the Narragansett Indian name, scuppaug. On the Virginia coast it is called the "fair maid." The porgy is found along our coast at all seasons of the year, but it is more numerous in June and July: The first run takes place about the beginning of May, and consists of large breeding fish, weighing from two to four pounds and measuring up to eighteen inches in length. On first Abundance coming near the shores they do not take the hook readily, being too much occupied in spawning, and two weeks elapse before they can be caught on the hook. They 


\section{Popular Bottom Sea Fish}

present themselves in schools of immense extent, numbering many millions, moving very slowly at about the rate of three miles an hour. The porgy is mostly a bottom fish and depends very much on

Food mollusks and shell-fish for subsistence, its especial food being small crabs, shell-fish, shrimps, and small minnows, but for bait the clam is by far the best; they also like the claws and legs of shedder crabs. Each leg when split open will make two or three baits just the right size for this fish. They will also go for small sand worms and blood worms when they will not touch other bait. They are gamy; if fine tackle is used their play is similar to that of the freshwater perch. Sometimes the larger fish just nibble and the angler will hardly feel a bite-yet the hook will be stripped clean. For that reason Tackle small hooks are much the best. Nos. 5
to 7 are the sizes. Large-sized hooks are only used when big fish are running. The sinker should be heavy to keep the bait in one place. Place the first hook six inches above the sinker, the second hook another six above, and it may be of larger size than the lower hook. The porgy has a large head and hard mouth; so that when even a touch is felt on the line, give a sharp, quick strike to firmly embed the hook.

For tackle use a light spring rod, though a reel is convenient to give a longer line at varying depths. Use a very fine line and small but extra sharp hooks.

From the first of August to the last of October 


\section{Fish and Fishing}

many anglers enjoy catching this gamy little fish; outside the sport of landing them, they are much

Time to Fish coveted as a pan fish. In flavor the porgy is surpassed by few other fish on the coast, although its superabundance causes it to be under-valued; the smaller ones especially are sweet and nutritious.

\section{SMELTS}

There are about a dozen species of this family which inhabit the cold and temperate Northern seas, but they are most plentiful along the coast of New England and the Middle States. The Eastern smelt grows occasionally to the length of a foot, but the average is about seven inches. They appear to associate in vast schools, somewhat according to size, each school being the spawn of a single fish.

The smelt remains about the coast, in the bays, throughout the year, save when it ascends freshHabits water streams to breed. As soon as the ice is out, smelts appear in the brooks, at first in small numbers, and the run continues till the middle of May. They ascend usually at night or on dark days. They will not bite during the spawning season. From the latter part of August to late December smelts will bite with avidity, and the best time is at flood tide, though some will bite at ebb tide, and many anglers claim that more and larger fish are caught at night, especially on dark nights. 


\section{Popular Bottom Sea Fish}

The best baits are these, in the order named: shrimps, blood worms, common garden worms, and Bait small minnows. Their favorite bait is shrimp, which should be placed on the hook, tail first, the point of the hook coming out at the head.

Minnows should be hooked through the lips, from underneath, with the hook coming out at the top of the nose. The rod should be no longer

Tackle

than eight feet; no reel is required, the line being tied at the tip, and the fish lifted right into the boat. Use a six-foot gut leader of medium thickness and attach to it four hooks, so that the end one will hang one foot from the bottom, the other three hooks being about one foot apart. The hooks should be small and the points sharp. A sinker tied to the end should be heavy enough to hold on the bottom, whatever tide runs, so that the hooks will float well away from the line.

At times they bite with such rapidity that they can be pulled into the boat as fast as the bait is put on. They are a swift-moving fish, and when once located a good catch is always the result.

If smelts are cooked within a short time after being caught they are most delicious eating; the larger fish have an oily taste, not so agreeable as the small fish.

\section{COD AND TOMCOD}

This well-known and prolific fish is not esteemed by anglers for its gamy qualities but solely for 


\section{Fish and Fishing}

its value as a table food. It grows to a considerable size, and is usually found in schools in great numbers and is readily captured. It is a deepwater fish, caught mostly in the open sea, in from eight to forty fathoms of water, from the fishingbank boats and sailing vessels. At night, during the summer months, they sometimes run in close toward the shore, when they may be caught off the long piers at Coney Island and other places.

They move in schools, periodically to and from shore, according to the seasonable change in the Popularity temperature. The codfish, as well as the tomcod, is a winter fish, and is caught at a season when so many other species that supply food are absent either in the deeper water, or have moved Southward into warmer waters. The codfish begin to bite early in October and so continue through the winter till the end of April. They feed upon all marine animals that are smaller than themselves, which are found in the same water with them; anything that is digestible is greedily taken by this voVoracious racious fish. So greedy are they that
Habits they have been caught with their stomachs filled to the greatest possible extent, having fish in their mouths which they have been unable to swallow for want of room; and in this condition they were still biting at the hook. Is it any wonder that they rapidly grow to an enormous size, frequently over one hundred pounds?

In fishing for cod nothing is needed but stout lines and heavy sinkers, and special cod hooks, 


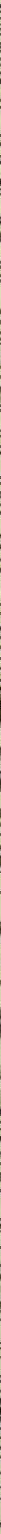

POPULAR BOTTOM SEA FISH 



\section{Popular Bottom Sea Fish}

which should be placed as near the sinker as possible. It is entirely a matter of choice with the angler how many hooks are used, though the limit seems to be three. The same may be also

Bait said regarding the choice of bait usedclams, crabs, worms or killies-it is all the same to this ravenous fish, who after taking it, makes no resistance whatever. The ease of its capture is only limited to its weight. If the cod is cooked within a few hours of its capture, the flesh is much harder and tastes sweeter than that of fish purchased in the market that have probably been caught three or four days.

The tomcod, in form, is a miniature of the codfish, rarely exceeding twelve inches in length. In some places it is called the frost fish, owing to the fact that it becomes more abundant in the early part of the winter. Angling for them begins in September, and the North River piers are lined with people who enjoy catching this dainty little fish. They are bold biters, playing fairly well when hooked. To get the best play and sport, Tackle use a short, springy rod, five to seven feet long, a light line and small reel with a light, three-foot leader, to which may be tied three hooks. The hooks should be close to the sinker, which must be heavy enough to hold on the bottom. Sand worms are by far Where the best bait, though shrimps or clams may be used. The tomcod can always be found near piers and bridges, in the rivers and inlets, during the winter months. As a 


\section{Fish and Fishing}

food fish, they are esteemed in many localities as a great delicacy. They are not caught in vast numbers like the porgy, but they are a favorite with most anglers because they resist capture a great deal more than their giant relative and namesake. .

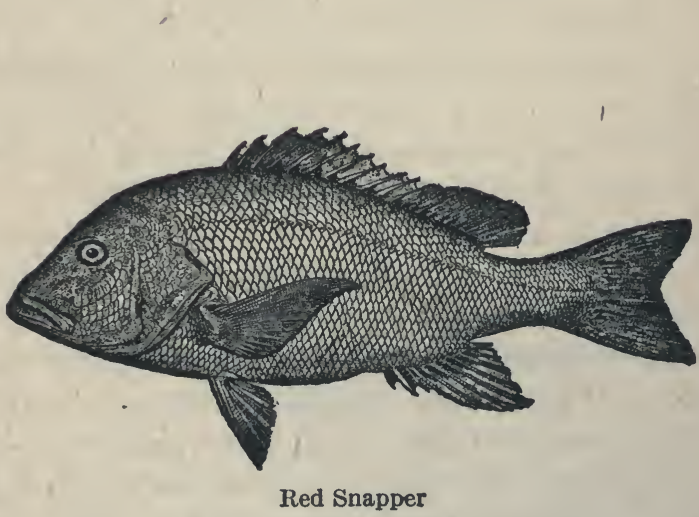




\section{CHAPTER V}

\section{Where to Get Them}

\section{GENERAL DISTRIBUTION-SALMON}

Nearly all fresh-water game fish are abundant in the cold or temperate regions, salmon and trout being more plentiful in waters chilled by winter's cold and snow. Bass, especially the large-mouthed, will thrive in warmer climates, where the waters are never frozen. Some species of trout and charr inhabit waters of comparatively warm regions, as in lower California, but, the rivers are cooled by snow water from the high mountainous sections whence the rivers flow.

Both the mascalonge and pike flourish and attain a larger size in the colder waters of the North, though the pickerel will exist in waters Distribution of a much higher temperature; so that the best game fishing of inland waters may be placed in about the latitude of lower New York, thence Northward to near the arctic circle.

To get good fishing for the true Atlantic Salmon the angler now must needs go to the British possessions in North America. Only in a few scat- 


\section{Fish and Fishing}

tered localities isolated specimens are, at times, caught, and those are a survival of artificial planting in the vain hope of a return to the once plentiful supply of by-gone years.

While Maine provides unequalled trout, togue, and landlocked salmon of remarkable size and abundance, its large rivers, like the Kennebec, Maine have been entirely robbed of this noble fish by means of dams and other obstructions. The real, true, game fishing for salmon with a fly is in the Province of New Brunswick; and the most famous rivers on the New

Brunswick

northeastern coast are the Restigouche (mostly private water), the Metapedia, Upsalquitch, Patapedia, and Kidgwick. Parts of these rivers are free to all comers, but the best pools are reserved either by clubs or private parties. The rivers on the north of the Bay of Chaleur are the Grand Bonaventure, Grand Cascapedia, Grand Romaine, and the St. Anne des Monts, in the Province of Quebec. On the St. Lawrence are the Godbout, the Moisie and the Mingan rivers, with a number of fair-sized fish in smaller streams nearer to the city of Quebec.

In Nova Scotia there are a number of small salmon streams with fairly good fishing, and Nova Scotia there, perhaps, is the most desirable place to go, unless the angler has unlimited time at his disposal and a deep pocket well filled.

Nearly all the rivers in the Province of Quebec and other places, comparatively easy of access, 


\section{Where to Get Them}

have been leased to wealthy clubs or individuals, who expend large sums in protecting their waters. Canada

The Godbout, I believe, is leased from mouth to source for exclusive fishing by members. There are many other rivers where the best fishing and pools are located which are strictly closed except to the lessees.

Fly fishing for salmon is the most difficult to get of any for fresh-water game fish. Many of the fish that are caught and reported as salmon are nothing but togue, or trout, or salmon trout that inhabit inland waters. The Atlantic salmon is never caught in lakes; it is only caught in the upper parts of rivers, which it enters for one object, that is to spawn, and then it returns to the sea.

\section{LANDLOCKED SALMON}

The landlocked salmon is found in many waters of northern Maine, but it is caught mostly in deep water, by trolling or still fishing, and very rarely on the fly, but withal, it gives excellent sport, and grows to a much larger size than the famous Saguenay salmon. Splendid fishing for Maine landlocked salmon is to be had in the numerous large lakes, the most well known among them being the Moosehead Lake, perhaps the finest fishing ground in North America. Immense catches are made every season by a large army of anglers, not only of landlocked salmon, but of trout, and togue of unusual size.

Other sections where the salmon is abundant, 


\section{Fish and Fishing}

are Lakes Sebec, Schoodic, Onawa, Squa Pan, and Square Lake. Salmon are also taken in fair quantities from some of the rivers, notably the Aroostook River; at Caribou and Fort Fairfield, specimens weighing up to twenty pounds being not uncommon.

The well-known and world-famous leaping landlocked salmon, which is found in Lake St. John, and its many tributaries, for its size, may be said to be the gamiest fish that swims. The centre of its abundance is at the Grande Décharge of Lake St. John, and in the differLake John ent large rivers flowing in, the Peribonca, Tschotogama, Mistassini and the Ashuapmouchouan, as well as a number of other rivers of lesser size but larger names.

The lake is reached in nine hours from Quebec, through a wild, beautiful country. On its shores is the hotel Roberval, where every possible comfort is provided for angling guests; guides and canoes are always ready, and the fishing is an experience all anglers delight to try.

As in other famous fishing resorts, the enormous quantities caught every season seem to have little effect on their abundance. Twenty fish to each person is the day's limit; the limit is often reached, if the angler is no duffer. All fishing is done in furious, rapid water, and only the fly is used to catch them; their play, as well as leaping traits are marvellous for so small a fish, the average being only three pounds, though some are caught up to seven. So far as is known, this species is 


\section{Where to Get Them}

confined to northern Maine and the Province of Quebec; a few isolated specimens may be taken in other localities, but not enough to be called good fishing, compared to that here described.

It is well known that the Pacific salmon will not take the fly, but magnificent fishing may be had in the salt water of Monterey, Santa Pacific Cruz, and Carmel Bays. The method is to troll in thirty feet of water with smelt bait and a spoon.

\section{MASCALONGE, PIKE}

The range of mascalonge fishing is limited to the country around the Great Lakes and to parts of Canada. Many so-called recorded captures of mascalonge are in reality pike. The greatest abundance is in the lakes and rivers of Wisconsin, parts of Michigan, Illinois, and Ohio. In the Eastern States it is rare. Beginning with Wisconsin Wisconsin, they are in the following waters: in the Chippewa River and various connecting lakes, in Cedar, Rice, and Long lakes, in the Rivers Wisconsin and Spirit; the River Flambeau and Lakes Clear, Somo, Otter, and Marie, at Birchwood and vicinity, in Lakes Red Cedar and Birch; near Edgewater, Lake Chelac, at Reserve, Lake Grindstone; near RhineCanada lander in Lakes Sugar Camp, Pine, Pelican, and Crescent; near Luck, in Lakes Butternut and Half-moon; at Hobson in Lakes Twin, Clear, Stone, and Stella; at Apollonia, in 


\section{Fish and Fishing}

Lakes Chain, Island, and Bruce, with numerous tributaries and smaller waters. In Canada, especially in rivers and lakes tributary to Lakes Superior and Huron, and in many parts of Ontario the mascalonge is fairly plentiful.

In the upper Ohio River and some of its larger tributaries it may be caught in the deep pools by still fishing. In Lakes Michigan, Erie, Huron, and Ontario they have been taken at times, but not in large numbers, though large in size. They are taken in Scioto and Mahoning rivers, in Ohio, Great Lakes and in Conneaut Lake, Pa., in Lake Pepin, Wis. and Chautauqua Lake, N. Y., the latter water being the home of the unspotted mascalonge, an excellent game fish, to my mind superior to the spotted variety.of the lakes.

In the Niagara River and the St. Lawrence, about the Thousand Islands, they may be said to be fairly plentiful, numerous catches having been made last season of fine large fish. There are no special places better than others, all the shallower waters near the shore of the Islands will St. Lawrence give good results. This fish has also been taken in some of the lakes and rivers of Kentucky and Tennessee, sometimes of a good size.

The pike has a much wider range than the mascalonge and it is also more plentiful. It is found, along with the pike perch, in a great many of the larger lakes in Canada, and grows up to thirty or forty pounds weight, numerous specimens of that size having been taken in the Sague- 


\section{Where to Get Them}

nay at Lake St. John, just at the outlet, near the Island House.

Large in size and abundant in number are those caught in Georgian Bay, in the St. Lawrence, and Lake St. George, the latter being the Pike most famous. From Lake Champlain Waters they may be found, down through the lakes in New York, New Jersey, Pennsylvania, to Kentucky and Tennessee. Michigan, Minnesota, Montana, all the States of the Middle West, have pike waters a-plenty.

\section{BASS}

The black bass, both large and small mouth, is at the present day so widely distributed that there are few sections in the United States where they are not found. This happy condition is due to the real worth of the fish as a gamy quarry, so that many States and private individuals have placed them in waters suited to their requirements.

Bass were introduced into the State of Maine by the commissioners in 1869. In New York State the commissioners planted bass in seventy lakes, ponds, and rivers in 1871. Introduction Private citizens of Pennsylvania Waters introduced small-mouth bass into the Susquehanna, Potomac, and Delaware rivers in 1873; New Hampshire, in 1864, Connecticut in 1852, Massachusetts in 1850. The black bass is indigenous in the waters of northern Wisconsin, and along the Appalach- 


\section{Fish and Fishing}

ian chain to the Carolinas and northern Georgia.- They were also plentiful in the Great Lake waters and Mississippi valley, Ohio, Originally Illinois, and Missouri River basins,
Found

the large-mouth being common along the Florida peninsula.

On the north-eastern coast some of the finest bass fishing to be enjoyed is at Belgrade lakes in Maine, notwithstanding the fact that a large number of anglers go there every season to try their luck, with never-ending success. Belgrade is composed of a number of lakes connected by various streams teeming with fish food highly suited to the bass; consequently they are big, Belgrade plentiful, and gamy, rising freely to the fly from early June till August. Other good bass localities in northern Maine are Seboois Lake and its tributaries, Schoodic Lake, the Piscataquis River, with many ponds and lakes near by. The Sebec Lake, which is connected by various streams, affords most excellent fishing. So widely have the bass been planted and so rapid their growth that it is impossible to give the names of the large number of lakes and streams, in that vast region.

Any bass fisherman who has not been to the St. Lawrence among the Thousand Islands, will find Thousand Islands

it well worth a visit, making his headquarters at Clayton, N. Y., where guides of real worth, and boats, roomy and comfortable, may be hired. There is no special place; it is all good fishing along the rocky shores 


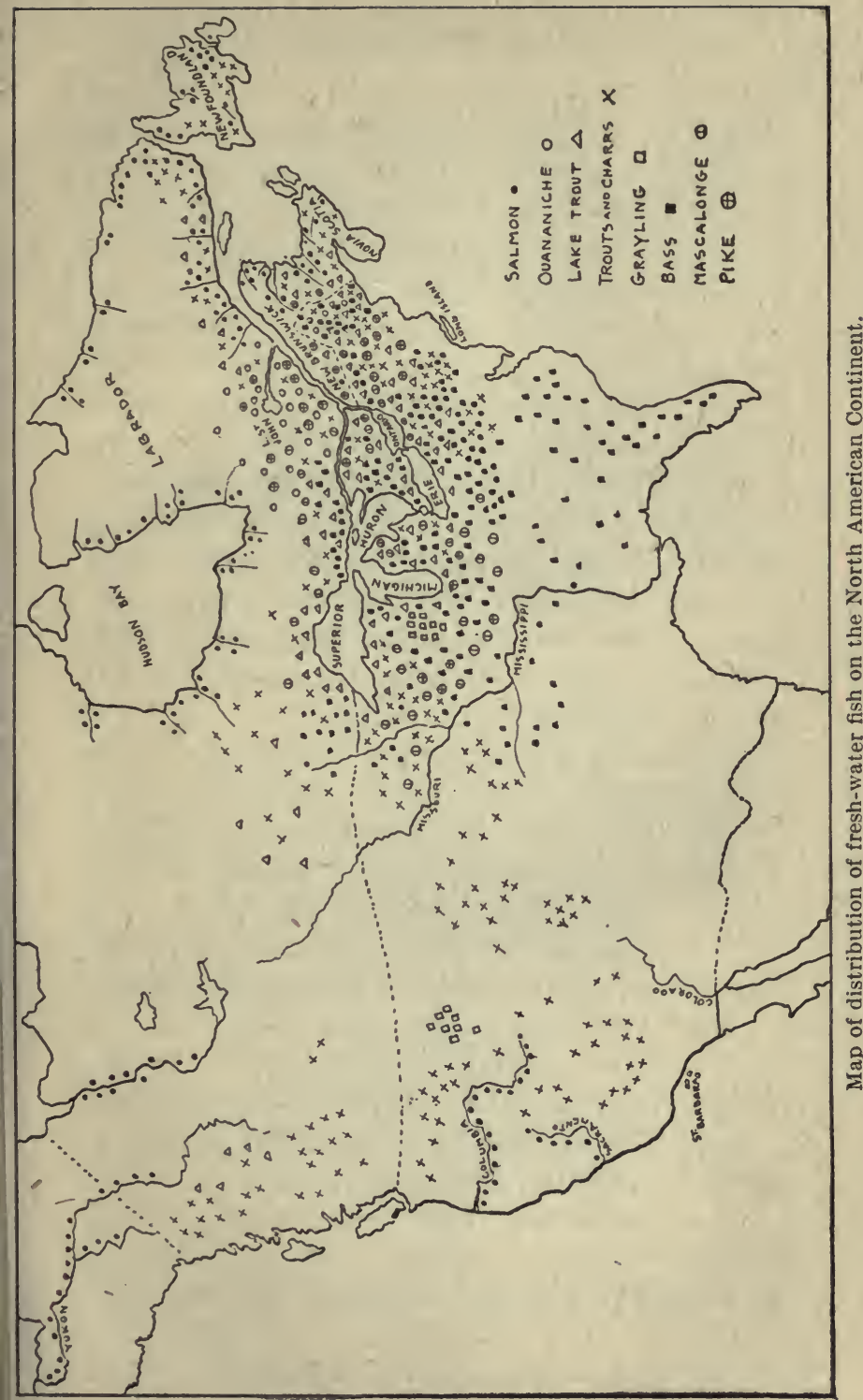




\section{Fish and Fishing}

of nearly all the Islands. Fish are plentiful, of good size, and gamy fighters. Mention may be made of Round Island, Fisher's Landing, and smaller island rocks which furnish glorious sport.

Skipping into Canada, and getting on the Canadian Pacific Railroad in Ontario, are the beautiful Rideau lakes, large, island-dotted bodies of crystal water, by many people considered the Canada best bass waters on the North American
Continent. A hundred miles from Toronto is Havelock, with very fine bass fishing in the River Trent, notably between Trent Bridge and Healy Falls, especially near the latter.

In central Ontario, but eight hours from Buffalo, are the ten Kawartha lakes, all literally swarming with gamy bass that, early in the season, take the fly.

Then there is the famous Gatineau River, with many tributaries and lakes dotting its winding course directly through the Laurentian Mountains; also the Chats Rapids, on the Ottawa Ontario

River, give splendid bass fishing. All these waters in Canada, while famed for bass, also afford magnificent mascalonge, as well as trout, very often in the same waters. In the native home of the bass, in the Middle Middle Western States of Wisconsin, Michigan,
West Illinois, Ohio, and Kentucky, the popularity of that fish is supreme,

In northern New York bass are abundant in Lake Champlain, especially near St. Albans. Bass anglers will find Samson's an ideal place 



\section{Where to Get Them}

to stay, not only for bass, but large pike. Side trips can be made to Raquette, Forked, White, Fourth, Bisby, and Sucker lakes; Cake In western New York by far the best bass fishing is in Chautauqua Lake, where the fish are large, pugnacious fighters, and I consider it as good as the St. LawChautauqua
Lake cause it also has the mascalonge. Bemus Point is a famous place for head-quarters. Within 150 miles of New York the best bass fishing is in the Delaware River, at East Branch, Delaware Deposit, Fish Eddy, Cook's Falls, and some distance along the Beaverkill. Both branches of the Delaware at this point are swarming with bass, above and below the junction, right down to Port Jervis. There are countless lakes and ponds, with their tributaries well stocked with bass, in the counties of Delaware, Sullivan, and Broome, in New York, as well as the counties of Wayne, Pike; and Susquehanna in Pennsylvania.

In the Schuylkill River there are many stretches Schuylkill of good bass water, particularly that from Royer's Ford to Yankee Dam, a distance of three miles, and about thirty miles from Philadelphia. In a like manner the SusSusquehanna quehanna River from Binghamton, on the north branch, and the Chemung River which joins it just below Athens, and nearly all the Susquehanna's many tributa- 


\section{Fish and Fishing}

ries, running down through the mountains to Harrisburg and below, furnish the bass fisherman with thousands of places to fill his creel.

The State of Pennsylvania is one of the most fortunate States in the Union, having a large number of bass and trout waters tributary to its two great rivers, which furnish ample sport to its hosts of fishermen.

Within a distance of fifty miles roundabout New York City there are many bass waters; in New Jersey are Greenwood Lake, New York Budd's Lake, Hopatcong, Pompton,
City Ramapo and the Raritan River.

In New York are Rockland Lake, Cromwell Lake, and Croton Dam; on Long Island are Lake Ronkonkoma and Peconic River; all these furnish rare good sport both on the fly and bait. Bass are plentiful in nearly all the Southern States. Florida stands first, both in quanSouthern tity and size of fish. From Jacksonville
States down to Miami there is a long chain of lakes, mostly connected by rivers, literally swarming with big fish, mostly of the large-mouth species, running up to fourteen pounds weight.

But, as previously stated, the natural home of the bass is the Middle West, with Chicago as its centre.

\section{TROUT AND CHARRS}

Of all the fresh-water game fish, the trout have the largest number of admirers, and along with the black bass are the most abundant and widely 


\section{Where to Get Them}

distributed of any fish. For that reason it will be necessary to class the different species together in two divisions-those caught in deep water (mostly by trolling) and those on the surface with the fly and worm. Surface fishing is more or less confined to brooks and small streams; deep fishing is often necessary in large rivers, and nearly always in lakes and ponds. Deep Water The angler must remember that
and Surface mountain-brook fishing is not so good after the first month of the season, because, to a certain extent, many brooks dry up; and in shallow water few places are available in which the fish can hide from the continuous assaults of worm and fly. Large trout, if they rise to a fly at all in big lakes do so only early, or very late in the season; and deep-water fishing is best at the end of spring and beginning of summer, when all traces of ice and snow water have disappeared.

In the large lakes, brook trout, or fontinalis, grow big and gross-up to ten pounds weight-if they feed on a fish diet. Three pounds is a large weight for surface-feeding fish in shallow waters, but their game qualities make up what they lack in weight. There are waters wherein the brown, rainbow, and even brook trout will live with the bass, but never with pike and mascalonge.

It is safe to say that the State of Maine stands easily first, as the most productive fishing ground for trout in the United States, both for size, quantity, and variety of species. 


\section{Fish and Fishing}

Its innumerable lakes and rivers, with countless tributaries, teem with fish, notwithstanding the Maine continuous drain on the supply made every season by an army of fishermen from all parts of the country. I shall, therefore, only mention its larger fishing places, the smaller brook fishing (though good) being of secondary consideration. In this vast region of 15,000 square miles of forest-covered land, with running streams that are tributaries and often connect its many large lakes, the angler will find plenty of sport, wherever he chooses to go.

In the waters of the Piscataquis and Hunt Brook, and in Schoodic Lake there will be found big trout and togue; near Milo Junction is Pleasant River with its many branches, all well stocked with trout of fair size; in Roaring Brook, Houston Pond, Hounston Brook, Mountain Pond, Lyford, West Branch, Greenwood, Cedar, Spruce, Chairback and B ponds, and the upper waters of PleasKatahdin ant River itself, is good fishing worthy of a visit. From there a ride by rail to Katahdin Iron Works reaches another good locality for big trout.

The Rangeley Lakes are widely known for their numerous and large trout and togue. Sebec Lake, a tributary to the Piscataquis River, is surrounded by good fishing in Goose Pond, Mill Rangeley Brook, Grape Pond, Long, Second, Third, Fourth, Burden, and Benson ponds. The railway to Monson, will place the angler near Hebron and many other ponds. Near 


\section{Where to Get Them}

Shirley are the Grove and Gravel brooks, Spectacle, Ordway, Indian, Trout, Notch, Round, and Moxie ponds, all full of good trout, not often fished for.

The famous Moosehead Lake is forty miles long by eighteen broad, a splendid expanse of water, and upon its shores stands Mt. Kineo House, whose guests take many big trout up to Moosehead seven pounds weight. A big togue having been taken from this water last season. Other good fishing in this vicinity is the Moose River, Brassau Lake, with many tributary streams Penobscot and ponds. On the west branch of the Penobscot River may be found numberless ponds, lakes, and streams containing fine, large trout and togue.

Below Caribou, the Aroostook River receives the waters of the Madawaska and its tributaries, the best being the Cain, Greenlaw, Brandy, Wolverton, Halfway, Black, Johnson, Bearsley, Armstrong, and McKlusky brooks, with many ponds and good-sized lakes as their source, all full of Aroostook trout, some large in size. Near Askland, on the Aroostook River, is the mouth of the Big Machias River, which has on both sides many tributaries. Other large and important fishing sections, providing excellent sport, are the Fish River, the Allagash, and St. John, each with many tributaries and their lakes and ponds, all famous for fine trout fishing.

New Brunswick and Nova Scotia are easily 


\section{Fish and Fishing}

reached from Boston and New York by rail or by water, and both provinces are honey-combed with large and small rivers, lakes and ponds, containing various species of salmon and trout. Head-quarters in New Brunswick can be made either at St. John, St. Andrews, St. New
Brunswick Stephen, or at Fredericton, for the following rivers: the Nashwaak, Tay, Miramichi, Cains, and the Clearwater, the Rivers Tobique, Forks, and Campbell. .From head-quarters at Edmundton there are many rivers from which to make a choice, the upper St. John, Madawaska, and Green rivers.

A short trip from St. John, N. B., to Digby, Nova Scotia, finds the angler in the vicinity of plenty of good trout and salmon streams, small in comparison to those of Maine and New Nova Brunswick, but the fishing is in the midst of beautiful pastoral scenery, kindly people, and most pleasant associations. The best waters are the Tusket lakes, Bras d'Or, and many small streams all abounding in trout.

On the north side of the St.Lawrence from the mouth of the solemn Saguenay, to the City of Quebec, are many splendid streams from lakes in the interior that are full of the fontinalis and sea trout, in particular those from Lake Edward and Quebec Jacques Cartier, all of which can be easily reached from Quebec City. In western Ontario may be found grand trout fishing in Lake Nipigon, and near the outlet of Georgian Bay is the famous Lake Nipissing. In Canada, as 


\section{Where to Get Them}

in Maine, it is only possible to mention some of the most prominent trout sections. It will be noticed Ontario that in Canada, as well as in New York, the fish called lake trout is the same species as that called togue, in Maine. During the last three or four years trout fishing in the Adirondack region has vastly improved, so that the future looks exceedingly bright, compared to ten years ago when trout were few and far between, and anglers were forced to go elsewhere for sport. This happy change has come about, by reason Adirondacks of ample stocking of the waters, not only by the State, but by wealthy private individuals and clubs. There are no less than thirty-eight lakes and ponds, as well as nineteen streams, in which the red-throat trout, brook, brown, lake, and rainbow are, in a measure, fairly plentiful, because they have been stocked every season under the auspices of the Saranac Lake Fish and Game Club.

This last season two lake trout were taken from Owl and Pine ponds, weighing twenty-six and twenty-seven pounds, both caught on small Archer spinners, with minnow, in deep water.

Many of the large lakes in western central New York are well stocked with trout; chief among them is Lake Keuka, which contains

Central New York big specimens of rainbow, lake, and brook trout. They are caught by trolling with spoons, having three branch leaders from the main line placed at various depths. It is a common occurrence for 


\section{Fish and Fishing}

anglers to get three trout on one rig. Catches of twelve to fifteen lake trout from four to six pounds are frequently made, even by amateurs. Specimens have been caught up to twenty pounds. Great Lakes

The lake trout is a native of the Great Lakes, and is found in its largest and best condition in Lakes Huron, Michigan, and Superior. In those lakes, specimens weighing fifty pounds are not uncommon, one having been recorded of the enormous weight of ninety pounds and six feet in length.

This covers, incompletely, the best deep-water fishing for trout. There are, no doubt, isolated sections in many States where good trout may be caught.

For anglers residing in the Eastern States, the best fishing I know for speckled, brown, and rainbow trout, in brooks and small rivers, caught on the fly and with the worm, is in the mountainous section of Monroe, Pike, and Wayne counties of Pennsylvania and of Delaware, Sullivan and Ulster counties in New York; also in parts of western New Jersey. The method of fishing in this section is mainly by wading down the rippling brooks, or in the middle of rivers, not over two Monroe, Pike, feet deep, under the most ideal and Wayne and favorable conditions-untramcounties melled, free to all, no guides or boats or long wearisome journeys. I have many times in numerous places creeled twenty-five nice ten-inch trout,

In Monroe County, the best locations are the 136 


\section{Where to Get Them}

brooks near Canadansis, Tannersville, Cresco, and Bushkill; among them are the Broadhead, Buckhill, Middle Branch, Levis Branch, Goose Pond Run, Spruce Cabin Run, Stony Run, and Mill Creek. Most of these are within easy reach of Spruce Cabin Inn, a pleasant place for anglers, where they will find agreeable company and good fish.

In Pike County are Shohola Brook, Panther Brook, Parker's Glen Brook; other trouting streams are Pocona Creek, Sandy Spring Creek, Wolf Swamp Brook, Still-water, Deep Hollow, Tunkhannock, Trout Creek, Tobyhanna Creek. Near Clifton is the Lehigh River, Belle Meadow, Pond Creek, Ash Creek, and Sheep Brook.

Right on the borders, where Sullivan County joins Wayne, are Narrowsburg, Cochecton, and Callicoon. The various streams are Ten-Mile River, Boyd's Mills Brook, Callicoon Creek, Hollister Creek, all first-rate, early-season trout waters, with some really good-sized fish. A few miles into Sullivan County are the Beaverkill, Willowemock, Mongaup, Neversink, Little Neversink, and their smaller brook tributaries. From Lew

Delaware, Beach to the village of Beaverkill, on Sullivan, to Rockland and Cook's Falls, is and Ulster good fly fishing for speckled, brown, counties and rainbows; from Willowemock Village to De Bruce, where the late Wm. C. Harris and I have landed many a good trout, staying at the comfortable Hearthstone Inn; thence to Parkston, Parksville; Livingston Manor, to 


\section{Fish and Fishing}

Roscoe, where at the Roscoe House is the best angler in the three counties.

The Mongaup at De Bruce is a fine, small, early stream. The little Beaverkill, a mile or two above Parksville Station, is a good small stream. A great many of the smaller brooks run into these larger streams, affording excellent early-season fishing. The upper Neversink is good, but the lower part near the O. \& W. R. R. is not so good as it will be in a few seasons; it is now being well stocked. It was formerly one of the best native trout streams in the county, wide with many deep pools.

In the central Catskills, numberless small brooks yield good fishing. Esopus Creek and others are well stocked. Crossing the Hudson Catskills into the Berkshires and thence into Connecticut, some distance back from the coast, there are many streams and brooks well stocked with trout, affording really good fishing.

In the mountain streams of North Carolina and Virginia, the brook trout is found at home, and Virginia may be caught in plenty during the early months of the season. Stocking has been going on for some years; though not very many visit that locality. The mountains of California California are full of fine trout streams; the beautiful Yosemite with its golden, as well as rainbow trout, affords splendid fishing. Lake Tahoe has trout of that name. In Colorado there are fine trout, big fish, and plenty of them; perhaps the best are in the Platte Cañon, only a 


\section{Where to Get Them}

few hours' drive from Denver. All along the cañon good accommodation is found, notably at Colorado

River View, Buffalo Park, Pine Grove, Altruria, and Cassells; at all these places the stream is close at hand. The water is ideal for casting the fly, rapid, plenty of falls and pools, amidst the most beautiful scenery and a delightful climate.

Long Island has a few small trout streams that are excellent fishing, but the best are reserved by wealthy clubs; well stocked, but well Long Island guarded. Those left open to the public are absolutely fished dry the first week in the season, so that as a fishing ground for the public at large it counts for nothing whatever.

Quite a number of the railroads are now, I am pleased to see, taking active interest in the fishing along their lines; some, more enterprising, maintain hatcheries and do stocking of their waters.

\section{POPULAR SALT-WATER FISH}

Many anglers want to know the best places to go; though it is impossible to mention all places in Canada and the United States, in the main, the best places are here given for salt-water fish.

For big deep-sea game fishes by far the best locality probably anywhere is in the neighborhood of Avalon, Santa Catalina, and adjacent islands on the California coast. There they are not only plentiful, but grow to a size scarcely to 


\section{Fish and Fishing}

be believed. The Eastern weakfish, known on the Pacific coast as the white sea-bass, grows

From

Pacific coast to a weight of fifty pounds and upward; it is gamy to a degree. But most famous are the tuna, yellow tail, barracuda, albacore, and giant black sea-bass, the latter reaching 400 pounds bulk. These and many other minor fish may be taken from April to December in Avalon Bay down the coast to San Diego. Further South, all along the Gulf coast of Texas, (leaving out Mexico) from Brownsville to Galveston, running along past To Texas
and Florida Louisiana to the Western peninsula of Florida, there are scores of angling resorts for tarpon, jewfish, barracuda, groupers, sword-fish, and sharks. From the Florida Keys, North along the eastern coast up to Jacksonville are the main fishing grounds for big game. In the vicinity of the tarpon grounds, palatial hotels, with every comfort, line the shore, easily reached by railways, opened up within the last few years.' 'The most famous tarpon fishing in Florida and Texas is at Indian River, Jupiter Inlet, Miami, Bahia Honda, Fort Myres, Pine Island, and Boca Grande. On the Texas coast the chief places are Aransas Pass, where the tarpon club is situated, Corpus Christi, Captiva, Marco, Naples, and other places.

From Jacksonville, Savannah, and Charleston to Norfolk, Va., at the proper season, there may be caught blue-fish, black-fish, hogfish, sea-bass, sheepshead, channel bass, kingfish, bonito, pom. 


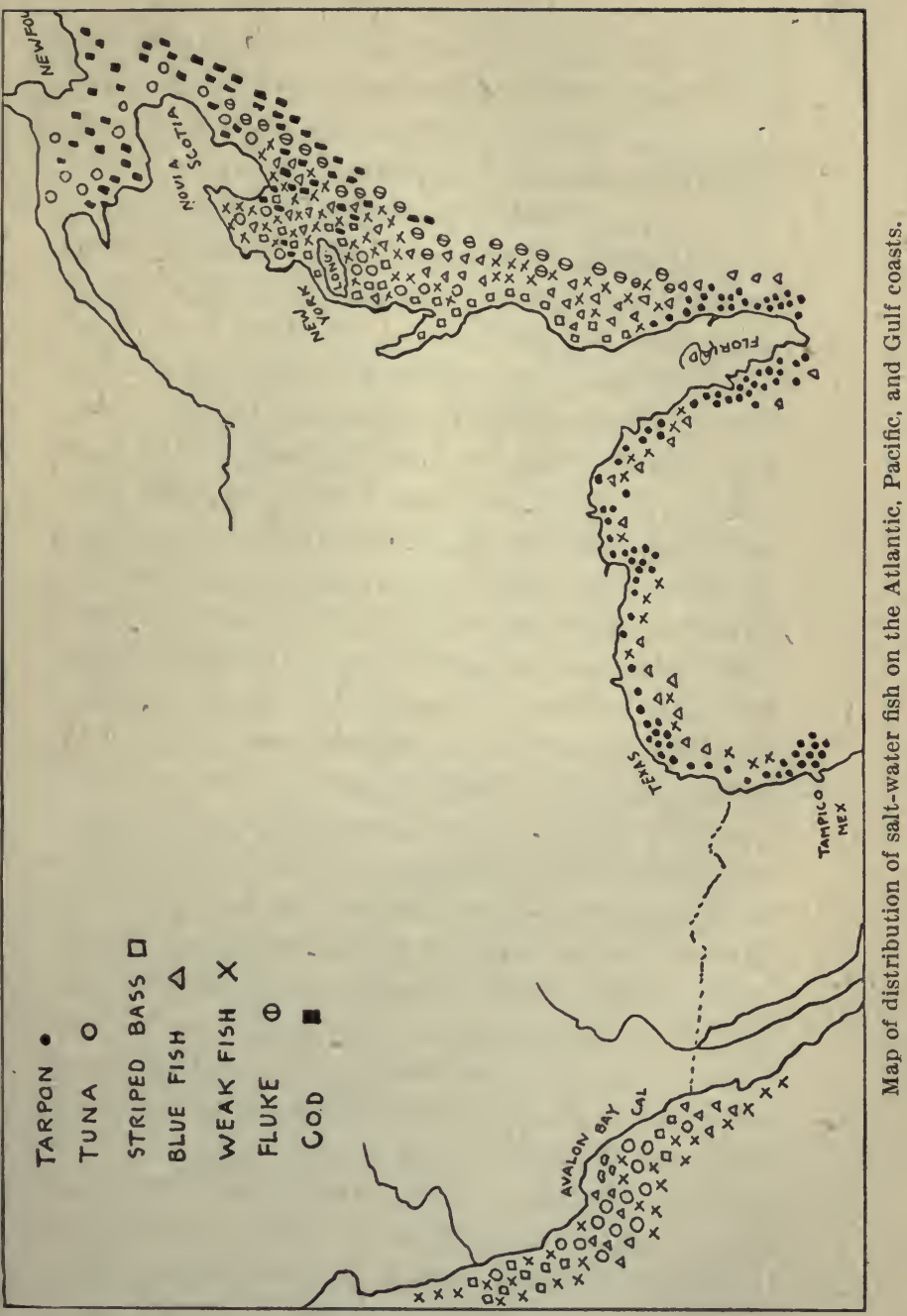




\section{Fish and Fishing}

pano, and many others. From Norfolk to New York, especially along the Delaware and Jersey coast, is perhaps the best surf fishing To Jersey on the Eastern coast. Every species of
coast salt-water game fish is taken, when in season, and in some places fishing continues right through the winter. The Jersey coast is particularly good for surf casting for blue-fish, striped bass, channel bass and weakfish: from Cape May, Atlantic City, Beachhaven, Barnegat, Belmar, Deal Beach, Long Branch, Seabright, Atlantic Highlands, Sandy Hook, Raritan Bay, and Perth Amboy. All around Staten Island, particularly the south-eastern shore, it is at all times literally swarming with fish, including striped bass, blue-fish, weakfish, fluke, kingfish, blackfish and sea-bass. During the summer months excellent fishing is to be had off the docks lining both sides of the City of New York-tomcod, eels, and Lafayette from the Battery to Yonkers; striped bass, from One Hundred and Twenty-fifth Street to Mount St. Vincent; striped bass, tomcod, Lafayette, at Hastings, Irvington, Ossining, Dobbs'

Ferry, and Tarrytown. From Hell Gate Hudson to Bridgeport, New Haven, on to Block
River Island and Newport, every available space of coast line has good fishing for striped bass, bluefish, weakfish, plaice, flounders, porgies, black-fish, eels, and Lafayette. From Newport to Buzzards Bay, Vineyard Sound, Nantucket Sound, and Cape Cod, are blue-fish, codfish, porgies, and smelts.

For variety as well as quantity, the south shore 


\section{Where to Get Them}

of Long Island furnishes the best fishing on the eastern coast. From the little juicy porgy up to a 250-pound tuna, or horse-mackerel, a 450-pound shark, or a 90 -foot whale, Long Island provides Long Island at some part of the season every
sea-fish that runs along the eastern shores. It is asserted that over thirty thousand anglers fish this strip of shore during the summer months; in addition comfortable sea-going steamboats carry a crowd of deep-sea anglers from New York City every day to the various wrecks that dot the coast. From Sea Gate to Montauk Point, there are hundreds of bays and inlets to choose from; a few of the best are as follows: Bath Beach, Coney Island (on Iron Steamboat, Dreamland, Steeplechase piers), Coney Island Bell-buoy, Coney Island Creek, Fort Hamilton, Fort Lafayette, Gravesend Bay, Rockaway Beach, Norton's Point, Plum Beach, Stone Pile, Ulmer Park. At Jamaica Bay is Barren Island, Big Channel, Block House Wreck, Break Water, Fishkill Channel, Flatlands Bay, Irish Creek, Pumpkin Patch, Rockaway Point, and Ruffle Bar. At the eastern end of Jamaica Bay is Beach Channel, Black Wall, Goose Creek, Hassock Creek, Hook Creek, Raunt, Silver Hole, Valentine's Point. On the south shore, Far Rockaway, Fire Island, and Great South Bay; the latter a large shallow bay, almost enclosed, full of fish and of great variety. Stations on the Long Island Railroad are near these various points-Hempstead Bay, Hewletts, Inner Beach, Long Beach, Woodsburg, and Wreck Lead. 


\section{Fish and Fishing}

On the north shore are numerous places. For fishing in the open sea are Black Warrior Wreck, Cholera Banks, Fishing Banks-this latter being very famous for large sea-bass, fluke, black-fish, cod, ling, and hake. Other places are Flynn's Knoll, Iberia Wreck, Romer Shoals, Old Orchard Shoals, and Oregon Wreck.

At all the above-mentioned places ample facilities are provided for anglers, boats, guides, bait, and tackle, if needed; all are within easy and convenient reach of New York City. From the first of May to late October plenty of fish are caught. Within the last few years, motor boats have taken the place of sail boats, so that fishing is much more sure, and the return home less doubtful. Salt-water bait may be purchased at many of the tackle shops in New York and Brooklyn, though it is, perhaps, the best course to get the bait at the locality where the angler intends to fish. 


\section{CHAPTER VI \\ How to Get Them}

\section{SALMON}

\section{WITH THE FLY}

There are two methods beside fly fishing for salmon that may be called legitimate, though not practised so much in this country as in Great Britain. They are spinning or trolling with minnows or the prawn, and also still-fishing with Methods worms, and the aristocratic angler knows too well that two other methods of taking salmon are practised more largely here than abroad, that is, netting and spearing. Thousands of fine salmon are by these means taken from the luring fly.

There are, it is probable, no two reasonable anglers who will not differ regarding flies. My own experience is not wide, for the few fish I have killed, as it happens, were all landed on one fly, Different of different sizes, that is, the silver docOpinions of Flies tor; yet the most famous master and experienced salmon fisher, Major Traherne, mentions it not in his list of taking flies, but Mr. Dean Sage, and many others, place the silver 


\section{Fish and Fishing}

doctor next to Jock Scott. It is a remarkable fact that both these flies have been in constant use for over fifty years; since that time nothing has been tied to beat them, or equal them.

The capriciousness of salmon, one of their few characteristics of which we are absolutely certain, makes it unsafe to lay down any but the most general propositions as to what colors or effects in flies are to be used under varying conditions; therefore I prefer to give Mr. Sage's list, because he was a salmon angler of wide and long experience in our own rivers, and it is to his kindness I owe my first experience in taking salmon. He says in part: "Perhaps bright or dark colors in strong, or high, or dark water, would be the Durham ranger, Popham, silver doctor, Jock Scott or Nicholson; for medium and clearing water, the butcher, Jock Scott, silver doctor, and black and brown fairies; for low water, brown fairy, Jock Scott, silver doctor. It will be observed that the Jock Scott, silver doctor, and fairies are included in the flies appropriate for all stages of water and varieties of weather; and although I have never done it myself, I think a man proMost Killing vided with an ample stock, of different sizes, of these three flies, could catch as many fish, in any river of this country, as if he had the entire stock of any fly tier in the world to choose from." Further on he says, "In addition to the above, the Britannia, the Nepisiguit gray, the Durham ranger, the Nicholson, the butcher, and the Beaufort moth, should 


\section{How to Get Them}

certainly furnish enough variety for the most fastidious angler of salmon.. It cannot be denied that there are occasions when salmon will take things they have never before seen, and which are as different from any of the creations of the fly tier as can be imagined. I took two on the Nepisiguit, with a bunch of muskrat fur tied to a bare hook, and salmon have been taken in the Restigouche with a bunch of red squirrel's fur tied in the same way."

It will be noticed that my favorite fly, the silver doctor, comes in all his lists, once even before Jock Scott. I have the same opinion of the silver doctor as a trout fly. I certainly would put it first on the list for any fish, at any time, in any

Remarkable place, but, it must be the right size. Flies

In all kinds of fishing with the fly, we get most success on the whole by concentrating our attention upon a few patterns of proved merit, and persisting with them.

\section{WORKING AND CASTING THE FLY}

The art of fly casting for salmon bears no relation to any other form of angling with a fly. If it is akin to anything it is to working a minnow, Method rather than a fly, and the salmon angler must get all the analogy with trout fishing out of his head. In casting, the object of the angler is to throw the fly above and beyond where he hopes the fish are lying, in such a manner that it may be brought by the stream, moving in a 


\section{Fish and Fishing}

lively and attractive way within sight of the fish, being gradually swept across to the anglers' own bank. To do this successfully, the angler must cast, not only acrossi, but down stream; and the more down stream the cast can be made, the slower will be the pace at which the fly Across and crosses the river, the greater will be
Down the chance of the salmon seeing it, the less will be the chance of it seeing the line, and the more easy it will be for the angler to keep in touch with the fly, during the whole time it is in the water. This is why it is so important to throw a long line in salmon fishing, even in a comparatively narrow river. It is desirable not only to reach the whole of the likely water, but to cover it at a proper angle. If the cast is made directly across the stream, the line bags in the middle, and for the first half of the cast the fly has the appearance of a dead thing being towed down stream by a visible cord, instead of something alive, being jerked by its own motion in the water. Two things especially should the angler bear in mind when actually casting and managing his fly: the first is that the salmon in fresh water has more curiosity than appetite, that he is not waiting for food, nor expecting it to come to him, as he lies in the water. The fly must rouse the attention of the fish and must do it attractively. Second, the fly should be of the right size.

As the fly works round from the opposite bank toward your side, the rod should gradually follow it, and, if you please, you may slowly lower and 


\section{How to Get Them}

raise the point of the rod a few inches which will cause the feathers of the fly to open and shut, if much line is not in the water. Many Jerk and experienced anglers say that thus to
Work the Fly work the fly is unnecessary, but it is very generally done. Perhaps the best plan is to fish a cast first without working the fly, and then, if that fails, to work it.

If there is very little stream, the angler must of course draw the fly, but in that case the water will probably be deep and the fly will have to be well sunk. In swift water, working the fly is not necessary, but in slow or dead water it should be worked quietly. Major Traherne says: "The To Fish proper way to fish a pool is to commence a Pool at the head, and fish it foot by foot. If the fish will not come to the fly, the fly must go to the fish, even if a shot or two has to be pinched on to the line to take it there. In very clear, deep water, salmon may often be caught by sinking the fly almost to their noses, and then working it slowly along with alternate sinks and draws, never bringing it to the surface. If the fish are shy, try various plans. Draw the fly slowly, then fast; work it slowly, fast, and not at all; Tease the sink it, draw it near the surface, in
Fish short, tempt the fish by all the means in your power. Salmon seem to care very little for the water over them being whipped. If a fish rises, and misses the fly, give him a short rest, about a quarter of a minute, rather longer in swift water, then where the stream is gentle; cast 


\section{Fish and Fishing}

again, a little above the place where he rose, and, if that fails, try a little lower down the stream. Then, if he still comes not, try a smaller fly of the same pattern, followed by the various patterns, as a last resort; leave him and try again in the evening. Always be careful the fly does not swim on its back or side."

In the larger rivers most of the fishing is done from a boat or canoe, which renders unnecessary the employment of switching, or the various underhand casts without a knowledge of which angling for salmon would be practically impossible in many British rivers.

The overhand or ordinary cast is made by lifting the line out of the water to the end where the fly is, and throwing it out behind to its full length before casting it forward. This is the most imCasting from portant part of casting, because a Canoe if there is a slack line at the time of the forward cast, the fly is frequently snapped off, and the line and fly alight in front in a tangled mass, far in direction and distance from where they should. In raising the line from the water, a little jerk should be given, just as the fly leaves the surface, which makes it travel up and back much faster than it otherwise would, and prevents the line from hitting the ground or the water on the back cast. It is desirable that the straightened-out line behind should not fall to a lower level than the angler's head, and if kept higher than that it is better. The rod on the back cast, to accomplish this, should go as little as may 


\section{How to Get Them}

be beyond the perpendicular. The higher the fly on the back cast, if straight, the less force is required Far and
Fine Casting getting it into that position or any to send it forward, and the knack of other, whereby the fly is straightened out on the back cast, is in applying sufficient sudden force as it leaves the water, where there is some resistance to add to the impetus necessary to put it where it is wanted. To use sufficient power in the right place, to get the fly straight out behind, and to know just when to begin the forward motion (the principal force in which is exercised at the first part of it, with just sufficient in the remainder of the cast to guide the fly and make it alight properly) can only be learned by practice; which, after a long enough time, enables one to cast far and fine without any consciousness of the methods employed.

Comparatively few fish are killed on casts of over twenty-five yards and the great majority on considerably shorter ones. It is impossible to give actual directions how best to cast; the nearest to it that can be done is shown in the cuts. The best cast, and the most scientific, known as the Spey, is accomplished either by wading or when standing on the bank of the river. It can only be Distance acquired by much practice, and specially by forgetting trout methods, which are delicate and gentle compared to salmon angling and its tackle. Luck does perform the most extraordinary feats on salmon rivers, but none the less is it true that the angler who throws the long- 


\section{Fish and Fishing}

est line well, and knows the river best, will hook most'fish in the season.

\section{TO GET THEM WITH LIVE BAIT}

Previous to 1893 no quinnat salmon were taken on the Pacific coast by rod and line, but in that year trolling for them was accidentally introduced during the fishing for mackerel.

Pacific Dalmon During the summer months, the salmon
Sal enter Monterey Bay to feed on large quantities of sardines, smelts, and squid. The method employed in fishing is hardly up to the standard of the Atlantic coast; indeed, no fly fishing is practiced; the quinnat fly has yet to be invented. Meanwhile the fishing is done in two ways: trolling with spoon, with and without bait, and with baited hook attached below by a heavy sinker. If bait is scarce a spoon is used, but natural bait is preferred. The most effective spoon Trolling with Spoon is the "Wilson," a No. 6 being most used. Its shape is long and narrow, and rounded at each end. A great variety and many different sizes of hooks are used on the same size of spoon; some use brazed treblehooks. But as soon as bait is obtainable, the spoon is abandoned and the sinker is brought into play.

The gear consists of a linen line from nine to fifteen thread, with a five-ounce lead sinker, having a brass eye in each end to which the line and snood are fastened. The snood is six feet in 


\section{How to Get Them}

length; half way between the sinker and hook is fixed a small box swivel, size No. 4, to admit of the hook turning freely. The bait is towed at a depth of at least twenty feet, and the usual sailing speed is four miles an hour. The best fishing is usually to be had during the forenoon and the best season is in June, and till well into Trolling
with Bait August. Twenty-five fish is considered a good day's catch for one hook, the average size being a little over twenty pounds, though fifty pounds are occasionally caught. There is a mixed assortment of sportsmen and market fishermen. The latter, are somewhat more crude in method, and if they use a rod at all (a common bamboo pole) they drop it as soon as the salmon is on and haul in, hand-over-hand style.

There are two live baits used in

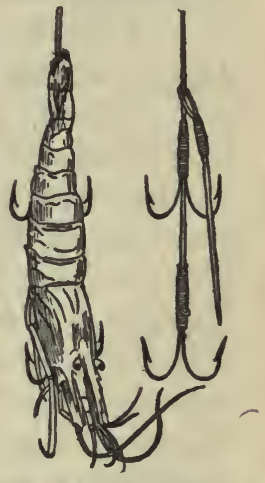

Prawn baited for salmon. taking the salmon, the worm and the prawn, the latter being an exceedingly effective bait. It is used The Atlantic when the water is low and clear and Salmon fly fishing is useless, but salmon will take it when the water is high, if it be clear. Before using, the prawn should be salted. The best prawn tackle is that shown above. The needle is put in at the tail and out of the head of the bait, and the point is then passed through the small loop on the shank of the lowest double hook; a few turns of red silk are then taken round the 


\section{Fish and Fishing}

tail to make all secure. A cast of fine single gut should connect the prawn with the reel line of fine dressed silk. The number of split Prawn
Methods shots on the line must depend on the depth of water and force of the stream, but the prawn should lie in midwater as near as possible. Prawn tackle may be trailed after a Working It boat or canoe, or merely cast across and a little down the stream, and allowed to work round like the fly; or it may be cast into pools, allowed to sink, and then worked with a sink and draw motion.

The worm, which is no less odious to fly fishers than the prawn, is a similar deadly bait for salmon. Worming is carried on when the water is still Thè Worm thick, but clearing after a flood; also good for the first few hours of a rise. The usual method is to bait a large hook with three or four common garden worms of the largest size, threaded for half an inch in the middle of their bodies; then cast into spots where salmon are known to be plentiful. The worms are cast repeatedly, and are allowed to trip on, or along the bottom. When a salmon seizes them the fish should be given a few seconds to gorge, and if he moves off at once, line should be played out, so that he feels no check. A weight on Method of Using the line is, of course, necessary, placed two feet from the bait, the weight depending on the strength of the current. The bait should be larger in very thick water than in water only slightly colored. 


\section{How to Get Them}

\section{MASCALONGE AND PIKE}

For some reason or other the mascalonge prefers the spoon in the early part of the season, and is not ready for live bait until the fall. In the In Rivers clear and swifter waters of the upper Ohio and its tributaries the mascalonge lies in the deep pools during summer and fall, where it is often taken by still fishing. A large sucker, weighing from one-half a pound to a pound, is the favorite bait, with suitable rod and reel. The fish is given plenty of time to

Still Fishing gorge before striking, this being necessary with so large a bait. Still fishing may also be practised on lakes, but the usual method is to troll. The best months are September and October, and the most favorable hours are early morning and late afternoon, though if the day be dark and cloudy, with a brisk wind, the middle of the day is just as favorable.

For lake fishing a live or dead golden chub or silver shiner or dace is the best bait, or a medium-sized frog answers very well. The bait Lake may be hooked on a similar gang to that Fishing shown for lake trout, only of a larger size, or on a Pflueger Imperial Minnow gang, No. 5. The same firm makes an excellent spinner known as the Olympia, adaptable for minnows. It consists of a pair of nickel fins which open and shut; the sharp points penetrate the gills, the nickel fins closing in at either side. The one made 


\section{Fish and Fishing}

for pike is quite large enough for mascalonge. There are numerous frog gangs on the market. The Ketchum frog-casting frame gang, Various Thatcher's floating-frog rig, and the
Gangs Crosby frog tandem are excellent devices. Rowing along in water from five to ten feet deep, the bait should be cast as far as possible to the edge of weed patches, reeling in again very slowly; or if the bait is alive,

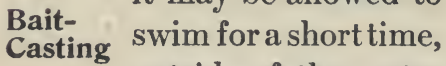
outside of the water plants. By moving along continuously and making frequent casts, this method is found much more effective than still-fishing. When the wind or current is just right, it is a good plan to drift while casting. As soon as the fish strikes and is hooked the boat should be moved to deeper, open water (taking

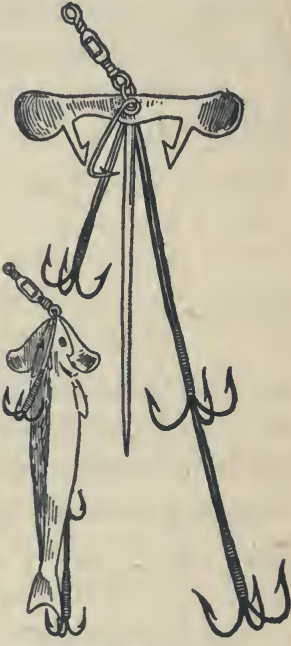

Olympia or Archer spinner for pike, trout or bass. care the line is kept taut in order to lessen the chances of it taking to the weed.) A skilled boatman is necessary.

'The bait may be trolled along the edges of the Trolling channel, just outside the weed patches, from a moving boat, with a line of thirty to fifty yards. A good, stout, stiff rod of eight feet, and a multiplying reel, a braided silk 


\section{How to Get Them}

or linen line, size $\mathrm{E}$ or $\mathrm{F}$, with sproat hooks No. 3-0-to 5-0 on gimp snells, and brass box-swivel for connecting snell and line, constitute the rest of the tackle.

Many anglers troll with hand lines of heavy braided linen, but the use of a rod is of much greater service in playing the fish. A fish of such excellent game qualities deserves treatment of a better kind.

\section{PIKE AND PICKEREL}

In live-bait fishing for pike exactly the same method is in order as that used for the mascalonge, except, if the pike are not of great size, smaller

- hooks and fish for bait are used. The angler must judge, or inquire from native fishermen or rèsidents, what are the best bait and size of fish; ask more than one, and see if their information tallies. In some lakes golden chub will not go and silver dace are only taken, and vice versa. In some lakes yellow-bellied frogs are no good; only whitePike bellied frogs are the thing because the fish are used to feeding on certain food. For medium-sized pike of ten pounds a shiner of eight inches is not too big, carefully hooked on minnow gang. It is perhaps the most deadly bait for the three members of the pike family.

Live-minnow gangs now on the market are so numerous and so varied that it is impossible to describe them; any will do if hooked the right way. In England, both trolling and spinning for 


\section{Fish and Fishing}

pike have reached a fine art, and much of their tackle is in common use here; but their methods are not copied, I think to our disadvantage. They lack the splendid array of artificial lures invented, and now in common use here.

Pickerel fishing is miniature pike fishing, with everything on a much smaller scale; the length of minnows should not be more than three inches; Pickerel frogs same size, with legs stretched, or large frog legs only if skinned and hooked in the centre, are good bait. A piece of bacon rind, cut in the shape of a minnow, often does good service; the cut-out lower belly of the perch with two red fins at top is a good trolling, or skittering, lure. Skittering is a method favorably known and in use all over the country. It is merely skittering or fluttering the lure on the surface of the water near lily pads and pickerel Skittering weeds. The movement is made by sharp wrist twitches, to which the rod responds smoothly, moving the lure in jumps of about a foot. Cast from open water, or from the shore, in a light and delicate way, so as not to kill the bait. Drop it just as if the frog or minnow was jumping, not with such force as to smash the life out of it, or send it spinning away from the hook. In trolling keep the boat always on the move, slowly and steadily; if a stoppage occurs reel in, because the bait sinks and is likely to get fast to snags and stumps. If the fish goes for the lure, and misses, go right on; don't stop, but return on the round to the spot it was taken 



\section{How to Get Them}

before and be ready to act if the strike is repeated. A pleasant and agreeable recreation is that of stillFililing or a frog; by this method it is an advanfishing from a boat, with live minnows tage to use a float to keep the line from sinking and getting in the weed; when the fish takes the bait allow a little time for it to get the bait well in its mouth. After it has done so, it will move away; that is the time to strike, quick, but not too heavy. When a fish is on the oarsman should go at once for deeper water to keep out of the weeds. When a fish once gets entangled in the long stems of lily leaves, it's as good as lost.

\section{BLACK BASS,}

\section{- WITH THE FLY}

All methods are considered legitimate with rod and line for bass, though fishing with a fly is more cleanly, less trouble, more humane. On Methods the best authority it has been said, "To be a successful fisher for the bass the angler must know something of its habits, its haunts and favorite resorts; on streams, the eddies of large boulders, deep water above and below, ripples, under shelving banks and rocks, submerged logs, and in the vicinity of gravelly bars and shoals." The most favorable time is morning and late afternoon, till dark. On hot days, the angler may take a rest during the noon hours; but a cloudy, dark day is good all 


\section{Fish and Fishing}

through. In wading one of my favorite streams, I hooked quite a number of fine bass while trout fishing with small flies, tied on No. 8 Places Pennell sneek hook, mostly after sunset; and with all due deference to many wellknown and good authorities on this fish, I think black bass, and more of them, can be taken on a trout rig, rod, line and flies. Anglers must remember when purchasing flies that in lakes large flies are necessary to be seen by the fish, especially in rippling water; but for fishing in streams, the right sizes for bass, large-mouth or small, are from Nos. 8 to 9 . Small hooks hold just as well as large ones, in fact, better, if the hook gets between the Small flies bones. What I say regarding metalSmall Flies bodied flies for trout, applies equally
in Rivers well for bass. As a cast of flies I should select the coachman, silver doctor, red or black hackle; as a change, cahill, gray hackle, March brown, or queen of the water, with the addition of black gnat, or black hackle; these in the different sizes mentioned will lure bass in most any locality. The rule applies with all fish-smallest and most sombre colors on bright days, in low and clear water, larger and brighter flies on dark days with high or rough water, and the same at evening.

When the angler is wading the middle of the stream, and able to cast far enough to reach both banks, and that is very desirable, he should carefully cover every point where large bowlders make eddies; in quick running waters bass move 


\section{How to Get Them}

from place to place, and are just as likely to be at the edge of the stream as in the middle, so that it will be wise to move slowly and carefully, without floundering about, and every fish hooked should be as soon as possible worked shoreward; it saves time and temper, and baskets more fish. That done, return to the same spot, and cast in the same place again. It is quite likely there are more where the other rose; if not, float the fly further down, let it sink somewhat, and jerk it sideways. This movement often draws the attention of the fish more than if it floats on the surface. Bass, more than most fish, dart after moving lures; often they take the fly, like a flash, as it drops on the water. Bass like a long, deep pool; such a place I know, where two Jerk the small rivers meet. Between the meeting of the waters there is a long line of bubbles, continually flowing with many drowned flies. On each side of this line for 100 feet the water is ten to twenty feet deep. In the early part of the season it is full of a variety of fish-brook trout, brown trout, rainbow, bass, large chub and dace. It is very difficult to get near enough to cast unless in plain view; therefore few of the larger fish are taken, but at evening, casting fine and far, I often take out of the pool several nice fish, just at the time they are flopping for flies in all parts of the eddy. All pools should be fished from the bottom, casting up stream; in that way the angler is not so easily visible, for bass are very shy and extremely wary. Caught unawares they are bold, 


\section{Fish and Fishing}

but after jumping and getting away that is the last of that fish for the day.

Fishing on lakes and ponds is quite different from river fishing. The time of day, weather conditions, flies on the wing, all have influence in getting bass to rise to a fly. I find that Weather Conditions

a windy day, or rather rippling water, gray and lowering sky, just after a rain, on a warm morning, is about the best time to get a rise. Then use No. 6 or even No. 8 flies, allowed to sink a foot or two. Cast far enough from the boat, which should be kept in deep water, and cast toward the shallows of bars, shoals, and weed patches. If the angler is fishing from shore, he should keep out of sight, hiding behind trees or brushes. When larger flies are used, Keep out two are sufficient on the cast, the end
of Sight fly to be the lightest in color, the upper (two feet from it) a darker fly with red or yellow; the professor makes a good upper fly for such conditions. For evening, I would fish with the end fly a coachman, and the upper fly Kind of a queen, or king of the water, the only difference being the red or yellow body. I doubt if there is any difference when in the water.

It often happens that as the fly is being taken from the water a bass dashes after it. This proves that the flies lying idly on the surface are of little value; if they sink, it's better; but better still, when under water, if they are moved from side to side, or up and down in short jerks or 


\section{How to Get Them}

runs; the fish are more likely to take them. Have, therefore, the flies on the move as much as possible. Of course, if you see a bass rising to the sink the natural fly, make every effort to get Sink the within casting distance, and drop the cast in the very spot. If there is no response, repeat the cast a few feet away. My experience has been that bass are not often in the humor for flies; only when conditions are just right, on lakes or ponds, can they be persuaded to rise to any extent. Your neighbors, but a few yards distant, are possibly landing them right along, using a shiner, and if flies will not draw them up it will be an advantage to follow suit, that is, if you want to land fish.

In short, if the truth be told, the bass, both large and small mouth, is a perfect live-bait fish in quiet water. In running, swift and rocky bottom water, it is a splendid fish for the fly, and may be relied on to give as good an account of itself as any fish for its size.

The bass takes best baits peculiar to the locality. In some sections it takes a lamprey eel more readily than a minnow, in others a frog; but for all sections the minnow heads Favorite the list of lures for black bass. The
Minnows first favorite is the shiner or dace, whose silvery sides show brightly in the water, especially so for rough, colored water, cloudy or dark days. Next come the golden chubs, good for bright days with clear water; their tougher mouths endure the hook longer and they are 


\section{Fish and Fishing}

more hardy and lively than the shiner; for that reason many anglers like them best. If the two mentioned are not available, young perch are good bait, but their spines should be clipped off

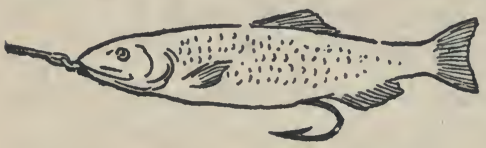

Shiner baited on a single hook. with scissors. This operation, if done neatly and with dispatch, does not impair their vitality. They are better in the early part of the season. Young suckers are also very good bait in low, clear water, and their tough, leathery lips hold well on the hook. The common striped minnow found in little brooks, if a good size, is a very enticing bait, and especially good for trolling or spinning; its lips are too . tender to hold on to a single hook, so that it is best to hook it fast through the How to Hook body. The best length for these
a Minnow baits is about four or five inches. Even a small bass will go for that size, but the big bass like a good-sized bait. In baiting with minnows the hook should be entered through the lower lip and out Two-hook minnow, live bait spinner. through the nostril; in this way they will live for some time-though a dead one, thus hooked, floats in a natural way. On small streams, while wading the shallows and bars, the bass being very shy, 


\section{How to Get Them}

the angler must proceed with caution, casting right to left across the stream from the banks and the middle. The bait rod is, compared to a fly rod, short and stiff, and the casting of bait is done to one side or the other, by underhand, the length of the cast being mostly due to the weight of the bait, and swivel, or sinker, the latter being heavier or lighter, according to depth or movement of the water.

Next in order, as taking bait, I should place the helgramite, an ugly looking black creature known Helgramite

by many names, indeed, every section of the country has its own peculiar name; they may be found clinging to decaying timbers, in the crevices of submérged stone-work, also in the shallow ripples under flat stones. They are good

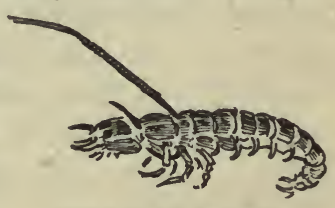

Hooked helgramite. because they are so hardy, living almost any length of time in a vessel half filled with rotten aquatic plants. This creature, by means of its strong pincers, clings tenaciously to various objects especially under stones, logs, even in swift-running streams, so that, when using it as a bait, it should How to Hook be kept forever on the move to stop Helgramite such tantrums. The way to hook it is by inserting the hook under the cap or shell that covers the neck, from behind forward, and bringing it through next to the head. It is a capital bait for bass, especially in rapids or shallow water. 


\section{Fish and Fishing}

In many localities the crawfish is an excellent hait, especially at the season when it casts its shell, when it is called a "shedder" or "peeler."

Crawfish

They are found beneath stones at the sides of rivers and brooks, under shelving grassy banks, among the pebbles; some bore holes in the meadows. The crawfish is not used

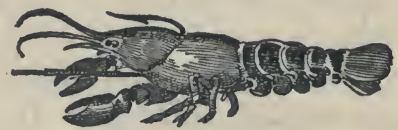

Hooked crawfish.

in casting or trolling, but in still-fishing. It has a bad habit of getting fast under any object it Hooking can. In its usual state, the way to hook it is through the tail, but when the shell is off, it is safer to hook it through the body. Crabs may be kept a long time in wet grass or moss.

The lamprey is quite as good a bait as the crawfish, and also gets fast under logs and rocks. Lamper=Eel

It is known as the lamper-eel and inhabits fresh water of small rivers and brooks. It is usually found in the muddy sand, partially under water. To capture them it is necessary to dig with a spade about nine inches deep, throwing the mud on the dry bank and searching through it for the wriggles. It is back-aching work to get them, and the angler, after some little experience in lamper-digging is inclined to be over-generous to boys who get them for him. They are, after being impaled on the 


\section{How to Get Them}

hook, quite lively, but soon die. In that condition they are useless. They should be hooked a little Hooking above the middle near the head, and are skittering, not for trolling. They should be kept in cool water with a plentiful supply of grass; they are not so hardy, and rarely live through the day, unless the water is constantly changed and kept cool. Bass take them with avidity, and so do large chub, sometimes trout.

The small catfish is another favorite bait with many bass anglers. They can easily be captured under stones along the shores. Get a good heavy stone to use as a hammer, and on seeing a stone with a shelving side, and flat at the bottom, strike it quickly and sharply on its top; lift it up at once, and you may find underneath one or more catfish from two to four inches long, stunned Young and helpless. Seize them quickly, avoiding the back spines, as they recover and disappear almost in an instant. This bait is very tenacious of life, and on a single one as many as five bass have been caught before the catfish died.

Young frogs are often used for bait with good success in running streams as well as marshy ponds; also the hind legs skinned, of the larger frogs; they may be skittered on the surface, in stillFrogs fishing, and a favorite method is to allow them to float down a runway. In hooking them, the point should be inserted through the under lip and brought through the tip of the nose. 


\section{Fish and Fishing}

They will live for some little time, if not beaten hard on the water. They are especially good around weeds and lily pads.

Grasshoppers and crickets at seasons when they are full grown, are most attractive to bass. Cast lightly on the water; they will float alive down the stream on the surface. In their'struggles they soon attract the attention of bass, and are taken under with avidity. They are just as good

Crickets when dead, if a ripple on the surface is made by a brisk wind. Bass are always on the lookout for these fat toothsome dainties. They should be hooked through the upper part of

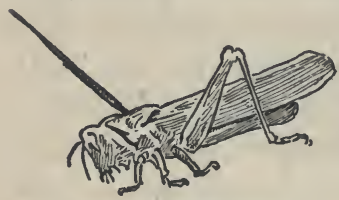

Hooked grasshopper. the body, and a smaller hook employed. On large hooks they kick themselves up from the point.

Other minor baits are salt-water shrimps, either alive or preserved in salt brine. Sometimes the large worm, called night-walkers, is good bait. The number and variety of live bait that entice black bass have not yet been definitely settled. Certain it is they will take any living thing, small enough, and even sometimes too large for them to swallow. They are often found with sunfish in their gullets; the spines, upper and lower, seem to be no impediment, for they turn them and swallow them head first, the fins closing down like a fan, and slipping through without any diffculty. 


\section{HOW TO CAST, WITH LIVE BAIT AND ARTIFICIAL LURES}

Doubtless nine-tenths of the bass fishermen fish with bait, artificial or natural ; and next to fly fishing, casting the minnow is the most artistic mode of angling for the black bass. I shall not attempt to describe its methods, but readers are advised to study the chapter on it, written by Dr. Henshall in his "Black Bass" book. His treatment of it is ample and sufficient. A few brief words with one or two practical lessons on the stream will help the novice to understand its main idea. The angler stands on the bank of a Method of stream or lake, or in a boat, with a
Casting rod about eight feet in length, which is held, tip down, three or four feet from the body, either to the right or to the left; then with an upward swoop it is brought to about the height of the head, with the tip pointing in the direction of a rising bass, or where one is supposed, or hoped to be, the line running free from the reel until just a moment before the lure strikes the water, when it is stopped by the thumb of the Tackle angler. The tackle used is quite different from that used in casting the fly, the rod being eight feet long and rather stiff, with well made guides instead of rings. The reel of the best make should run as easily and smoothly as possible, and multiply from two to four times. The reel line most suited is the smallest size, $\mathrm{H}$ or No.6, 


\section{Fish and Fishing}

plaited raw silk, braided hard and close, and tinted, or part colored. Longest casts are made on the finest lines, but for very large bass, size G or No. 5 may be used; fifty yards is the usual length. Dr. Henshall's choice of a bass hook is the sproat, O'Shaughnessy, and round bend Carlisle, the most suitable sizes being Nos. 1 and 2 . Hooks should be tied on gut snells, but when pickerel or pike abound, gimp snells may be used. Pike and pickerel both readily take the same bait,

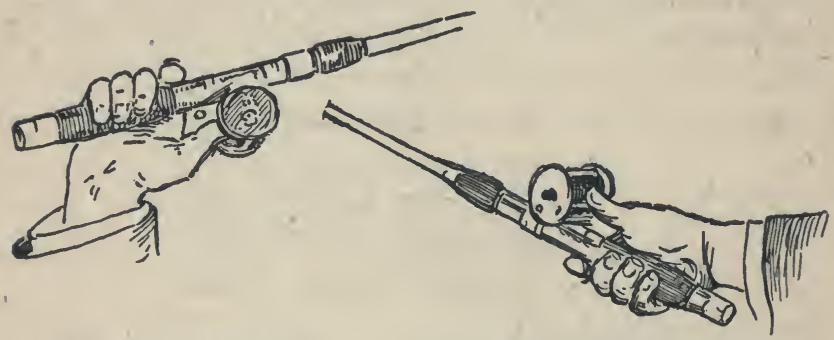

Ready for the overhand cast. Position of rod when bait strikes the water. The latest method of bait casting for bass.

live or artificial, as the bass. Where the fish live together it is not unlikely to get strikes from them. Henshall says, "The reel must be placed underneath the rod, on a line with the Rigging guides; the reel then being underneath,
the Cast the line is rove through the guides, and a box-swivel tied on the end; to the other ring of the swivel is looped the snell of the hook. The hook is then passed through the lips of a minnow from two to four inches long. If a sinker be required in addition to the swivel, it should be 


\section{How to Get Them}

placed a foot above it. Make frequent casts, if fish are plentiful; cast below the ripples, submerged stumps, and weed patches. When a bass takes the bait, let him have it from two to, ten seconds; if he bites eagerly, hook him at once. If he plays with it, keep the thumb on the spool; when he runs, hook him by a quick turn of the wrist. If in weedy or dangerous places, lead him to deeper water, never giving an inch of slack line till in the landing net."

Many still follow Henshall's method of reel underneath, but in tournament and practical fishing a short five-foot rod is now very popular with the reel on top, as shown in cuts.

\section{ARTIFICIAL LURES}

FOR BASS AND PIKE

Perhaps the most important device ever invented for the capture of fishes outside the hook is the spoon. It has paved the way for hundreds of ingenious, practical, and killing artificial lures for all kinds of fish. The most remarkable thing about them is that few attempts have been made to imitate natural bait, yet they have fully demonstrated their effectiveness in taking fish. Most of them are of recent introduction, and for that reason have not been mentioned in angling books. I can only mention and describe a few of the many worthy lures, calling the attention of anglers, especially of the East, to a very important and new 


\section{Fish and Fishing}

feature of fishing tackle. Many of our best trout and salmon flies are over fifty years old, and New Lures nothing since has been made to beat them; on the other hand, in the last few years, lures have been vastly improved. The honor has been left to Western anglers of producing an array of lures, both saving in expense and more humane, and less objectionable than live bait. Moreover, nearly all are simple, and their use is mostly for trolling purposes, a few being made for casting; others are clever methods whereby we can overcome such difficulties as trolling through weeds. Some, by their peculiar make, dart from side to side in quick movements, to imitate minnows. All have some good reason to recommend themselves. They are well worth the price asked, and should be tried by bass fishermen because they are on the market to stay, having been tested in the West where artificial lures are much more commonly used than in the East. Take, for instance, the well-known Dowagiac baits; in appearance and color they are very striking, as they spin perfectly through the water; the fish go for them and they take the fish every time. Their names Their are Bing's Nemahbin weedless minnow, Shakespeare's "revolution" and "evolution," the latter having attached the buck-tail; as a troller it is a certain "killer." In fact, the bucktail seems to be the coming lure for bass and pike, the former especially. Worden's buck-tail minnow and spinner are doing wonders in right hands, 


\section{How to Get Them}

that know how to handle them. The buck-tail seems to have found a place that the old redand-white feather had on the spoon. Pflueger has a buck-tail bass fly, trout fly, phantom, gang fly, casting spoon and minnow, each one of them being merely a bunch of white hair of the buck's tail, with different attachments, but all are quickly pushing forward as successful baits. Again, from the plain spoon has developed the pilot, the pilot spinner and turn-a-frog. Another good lure is the Mohawk darter, which has the remarkable feature of darting as well as revolving. The silver soldier is made of a thin, simple piece of silver, And Uses curved and shaped like a minnow. These, when properly used in the right places, succeed in luring fish. Trolled with a sinker, the silver soldier is a good lake-trout lure. Still more remarkable are the coaxer and teaser baits, shaped like a small bird with white body and red wings; they take fish a-plenty, in some way, perhaps by teasing and coaxing; if so, they are rightly named. The remarkable devices invented to slip through weeds are another development of tackle that takes a load of trouble off the angler. They may not always succeed, and may sometimes miss a fish if gingerly taken; but that is a small matter if they serve the purpose of going through a weed patch in comparative Weedless safety. The new idea of having spin-
Lures ners revolve both ways in order to avoid a kinking line is another boon to anglers, because many spin so fast as to put a stop to fishing 


\section{Fish and Fishing}

without such an advantage. An eastern lure, rapidly gaining friends, is the yellow kid, made by Wm. Mills \& Son, N. Y. It is painted a bright yellow, it spins through the water in great shape, and must attract attention a long distance from it. One would imagine that any bright object moving along the water would entice the fish to take it, if only from curiosity; always on the lookout for food their instinct moves them to grab a moving object to find out how it tastes; but, too late to draw back, the barb invariably holds tight and so captures them.

While these ingenious lures are doing their full share in taking fish, it must not be forgotten that the spoon is still a factor, and, in variety and effectiveness, a careful selection of spoons is invaluable to the angler. All large game fish take a The Spoon spoon, either alone or with attachments, made in every conceivable shape to suit different fish and locality, such as round, kidney, fish head, willow leaf, beaded, heart shape, grooved, curved and bent in every manner possible. There are spinners, single, cyclone, and double, some with feathers and some without. The Wilson spoon, a perfect eggshape, with a turned tip on the fore end, gives a wobbling motion that attracts fish; the darting spoon darts up and down and side to side. The Tacoma bait has two kidney-shaped blades, each revolving in opposite directions. The Lake Tahoe and Seattle Trout and McMurray spinner, the 


\section{How to Get Them}

latter an elongated heart-shaped spoon, spinning from a central tube, are effective for salmon and mascalonge. Most of them take fish, without the addition of feathers or live bait. Opinions are divided as to the use of bright feathers, hidGreat ing the treble-hook; some take the feathers
Variety off, in place of them fastening on a single large hook uncovered. It seems reasonable that if the fish take the revolving bright spoon for a minnow, the feather is entirely unnecessary. The same reason may be advanced against adding to the spoon a live or dead minnow. It would be an interesting experiment if some angler were to devote his time to angling for the various large game fish, and to confine himself entirely to the spoon, both with the attachments and without; of course, it would be necessary for him to be thoroughly acquainted with the seasons when the fish are taking spoons; for instance, the mascalonge, in Chautauqua Lake, will take the spoon and not the minnow (alive or artificial) in the Spring, and they take the minnow and not the spoon in the Fall. I was much interested on a recent visit to find that a local angler, J. M. Daniels, of Bemus Point, had made a spoon, most ingenious, and humane as well as effective. The spoon itself is made in steel, bronze, brass, and Mascalonge gold, the last expensive, being made Mascalonge from old watch cases; it is non-
Spoon tarnishable. In shape and size it is exactly like a table spoon, a trifle flatter, but instead of the usual triangle hook it has a 


\section{Fish and Fishing}

powerful double hook curved down, the barb pointing exactly right to pull as well as to hold. It is very artistically dressed to hide the hooks with buck's tail, red feather, and peacock feather. It did the trick; secured more fish than those I had, though anglers there admired my Pflueger tandem spinner, which I had success with. I am convinced that the triangle hook is inferior to hold, and to get a hold (especially the very large ones), to the double or even single hook. It is not often that a treble hook has more than one barb fastened; sometimes two, hardly ever three. If a single large hook is left free, it goes in to stay, it holds, and a double hook, Discard both points being one-sided, also takes Hooks hold to stay. Many expert anglers agree on this point; they invariably replace the treble hook by a single one. The larger salmon are taken on flies with a single hook, and the monster game fish of the sea are taken on a single, though of a good size; still the subject is a matter of personal opinion, and each angler will do as he pleases, whatever is said in books.

There is now a large bass fly, as well as trout fly, made with small spinners above, some revolving both ways; others single and revolving from a Trout Fly central rod. They are very attractive Trout Fly both for light casting on the surface,
Spoons and useful under water with sinkers, to be trolled along a few feet from the bottom and a few feet from the surface, wherever the fish may lie. These tiny spoons, glistening on a dull day, 


\section{How to Get Them}

can be seen better than the fly alone. Trout often refuse to rise to the fly on the surface, but readily take it, if sunk to the depth where they lie, the spoon acting as an additional lure.

Artificial minnows for trolling, casting, and spinning are made of rubber, wood, metal, and even glass, of all sizes. They are painted in colors, silvered and gilt; some are used with the fly at Minnows the end, others made with fly below and spoon on top, a combination that seems unnatural. The wooden, painted minnows with glass eyes and two nickle spinners are certainly killing for bass, pike, and trout. The mascalonge will take them just as readily as the natural minnow. Large and small trout take them, if suited to their size. The rubber minnow, silvered or painted natural colors, when made to spin properly, is also a favorite, but the silk phantom in any size seems to be in Phantom greater demand. The propellers cause them to spin perfectly, either casting or trolling; they should be slowly moved through the water when trolling. Those of the smaller size never fail to lure pickerel, perch, trout, and the larger pike, mascalonge and salmon. Bass, I think, at all times and places, go for a.phantom minnow in running rivers or quiet lakes. I have taken bass on a phantom minnow with treble hooks removed, and single ones in place. The trouble with small phantoms is that they soon become chewed out of shape and therefore do not spin properly; if the body, instead of being simply. 


\section{Fish and Fishing}

skin, could be filled with a light pliable substance, it would obviate such a difficulty.

The soft-rubber imitations of frogs, dobsons, crawfish, grasshoppers, and worms, are not yet made well enough to deceive even a fish.

Rubber Imitations They are clumsy and so cheaply made, no doubt by machinery, as to be worse than useless. They are only successful when played skilfully in rapid motion, and the fish go for them suddenly. These smaller lures should be made, like flies, by hand, of material that will give a more natural appearance, and the forms designed in a taking manner. A good frog, modeled in the attitude of swimming with a single hook on its back, would,
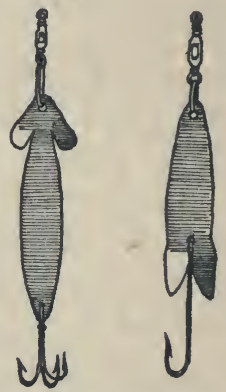
no doubt, take fish, and plenty Hand-made spinners of them. As now made, they are nothing near what the minnow is for trout, bass, pickerel. capable of doing. After all the efforts made to lure fish, the old-fashioned, plain, simUse, Not ple spoon, with but a single hook,
Ornament either cast or trolled, without bait or feathers attached, and placed in the hands of an angler who knows how to properly use it, will do wonderful things that would surprise the novice who uses the most complicated and advanced tackle. That is why so many will not give a trial to new things, and the manufacturer goes on producing unusual lures: 178 


\section{How to Get Them}

whereas the old ones, if improved, would be better.

It is not so much the lure as the working of it properly, placed at the right depth, moved at the proper rate, and used at the right time. This is not easily told in books; it is gained by experience, combined with sense. In short, the angler should endeavor to get the best out of any lure he

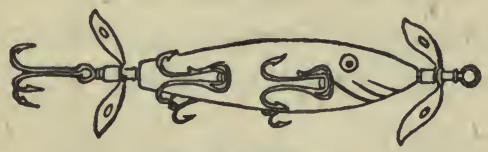

Wood's Expert.

uses; in every one of them there is some good and the problem is to find out where that good lies.

Fly, spoons for bass are practical; the little Fly Spoons spoon draws attention only when it is worked in a lively manner, below the surface, or cast and skittered on the surface.

Trolling is simple; more depends on the steadiness of the oarsman and his knowledge of how fast he should move to suit the lure used. Casting and spinning depend for success upon the way they are done. A good caster or spin. ner takes twice as many fish on the same lure as a novice, and to be an expert caster or spinner is an art requiring much patient practice to make perfect.

The manner of working artificial lures is so varied, according to the kind of fish as well as lure, that it is only possible to describe the most 


\section{Fish and Fishing}

important needs; but even from such a description, with a very little practice, any intelligent Kind of Fish and Lure angler will be able to take a lure where fish are, and catch them. Spoon and minnow lures are used mostly for bass, mascalonge, pike, pickerel, various trout, and, in some regions, salmon. The angler, if strange to the locality, should endeavor, first, to find out a local boatman, guide, or native angler, and question him regarding the fish, what they are, where they lie, what bait they are caught on.

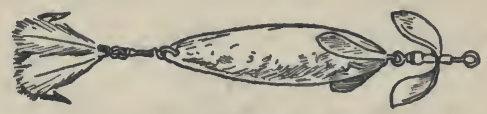

Haynes Pearl Minnow.

Guides usually insist that their methods, baits and themselves are the only means of getting fish. In rare instances it may be so, and your carefully selected tackle goes for naught for a while. You can then test your own ideas and tackle, which will be an interesting comparison. Nine times out of ten, if you are up to snuff, and understand yourself how to work things, you will do quite as well as the guide. In lakes and ponds bass frequent rocky bottoms, sometimes sandy, at others weedy; they rarely frequent very deep water. You will Find Depth soon find out, if the boatman does not know, how deep the water is by the rate your minnow or spoon sinks. I always carry a sinker and get the soundings when boating. Water round the edges is nearly always from two to fif- 


\section{How to Get Them}

teen feet deep; weeds are a good test of depth. Minnows and spoons should run through the water about two feet deep (rowing just fast enough to make the lures spin) and should be kept in the water that depth; whenever the boat stops, reel the line in, or it gets fast at the bottom. In turning round make a wide sweep and the lure will follow; if a sudden turn is made the line gets snagged. The same depth should be maintained for mascalonge and pike; a little deeper does no harm if there are no weeds. For deep water trout

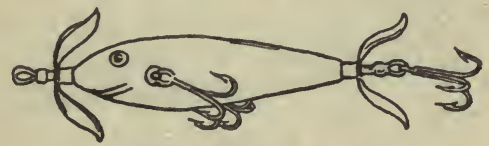

Dowagiac Rainbow.

a sinker is necessary. They sometimes lie forty feet deep in unbroken bottoms, jumping in places from forty to twenty; that can be found out by sounding. When a fish takes the Row Slow lure, whether you get it or not, it is wise to remember the length of line out, and rate of rowing, so that it may be repeated.

In using light lures and fly spoons for casting on the surface, the rule is to cast just inside of the weeds, or nearest the centre of the lake: This applies to all fish, more especially pike, mascalonge and pickerel; but for trout and charrs, round or near the mouths of fresh-water, running in, are the best places to work at. Trout are, perhaps, the hardest to find in lakes; they lie at times in shallows and at other times in the deepest parts, ac- 


\section{Fish and Fishing}

cording to the season and the weather. In large rivers, and pools that are deep in small rivers, the In Pools spinning lures as well as the spoons can

be let run down with the flow of the water, if forceful enough to make them spin; or they can be cast and drawn in against the flow of water. Lures are not effective worked in water less than two feet deep. At such times only light surface spinners should be used. A taut line must be constantly kept in working the lure, and when

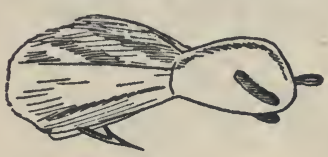

Coaxer. a strike occurs on a spoon the fish should be at once checked, and if moving, the boat should be stopped and the rod tip raised, and the hand brought to the reel immediately.

It all depends on what fish it is, and how big; if a large mascalonge, or any large fish, wants to go and it is away from the weeds, let it have the fun of the run. Keep the rod up all the Let Fish time, let the tip bend and do the work, or, if the fish wants you to have the fun, reel in all it allows you. Let this go on till you feel you have command over it, and can, with safety to the tackle, bring it toward you. Always let a fish have any amount of reasonable play if the tip is up and line taut; sudden jerks fling it off the hook; too strenuous reeling in is most likely to witness his departure. The first, second, and third rushes of a big trout, salmon or mascalonge should have the tenderest attention from you; your savage and stern demeanor are better reserved till the fish is 


\section{How to Get Them}

boated. All artificial lures require that the fish be struck immediately it takes them, for it feels the artificial nature of the lure as soon Let the
Fish Work as it touches the jaws. With the natural minnow you must wait for it to be gorged. The lure is different; it is like the fly; promptness wins the fish. Very often in striking

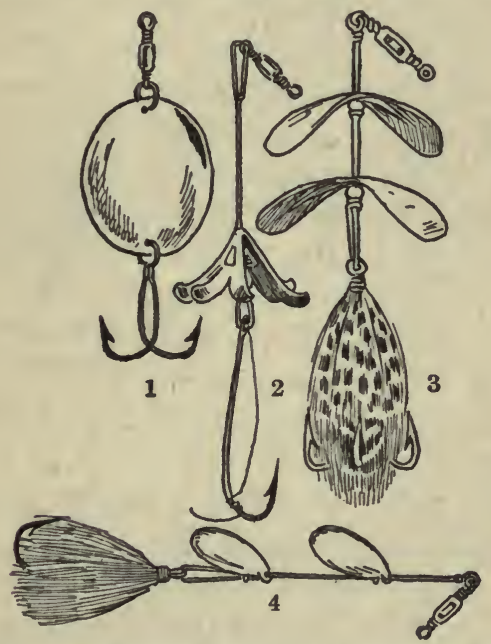

1. Pflueger's Wilson spoon. 2. Cyclone spinner.

3. Tandem spinner. 4. Buck-tail trout spinner.

it hooks itself; in that case you will know by its actions, usually a leap above the surface, or a surge down below; in every and all cases, bring the butt close to your chest and rod tip in the air. Of the artificial lures illustrated herewith, all have either been tested by the author, or he has reliable and trustworthy endorsements of capable experts. 


\section{Fish and Fishing}

The Wood's Expert is one of five varieties, and the advantage of it is threefold. "It has double instead of treble hooks at the sides, so that

Wood

they lie closer and fit snug against the Minnow body, yet they are more effective; the hooks can also be easily detached if required. Another good feature is the perforated spinners, giving, as they do, less resistance and friction in retrieving. Then, again, it always floats, belly down, and can be used either at the surface or allowed to sink as desired.

The Haynes Pearl minnow is another excellent lure; the body being made of pearl is naturally

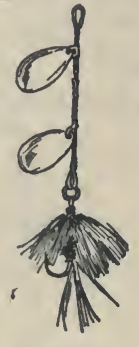

Trout spinner.

a better minnow imitation and it is always bright and luminous, however much used, and cannot be bitten and cracked, like the painted wood minnows. It does

Pearl away with side hooks, having

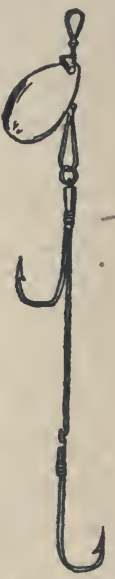

Hildebrandt casting spoon. the tail, the spinner at the head.

The body runs along without revolving, and its iridescent appearance must be attractive to game fish from a long distance.

The Dowagiac minnows, of which there are numerous designs, both in shape and color, are beautifully made; and in color, I think, impossible to improve, so natural do they look as they move along in the water. They are justly a favorite 


\section{How to Get Them}

because they attract fish, and securely hold them. They are constructed with single pairs, double Dowagiac pairs, and single treble hooks, with two spinners, one at the head, the other at the tail.

The Jamison coaxer is one of the most original lures ever invented. Its holding power is limited to one large hook, hidden most artfully inside two large Coaxer red wings. It looks, practical lure, and it holds the quarry, as well as coaxes it. It has come to stay as a general favorite with all bait casters.

The Hildebrandt spoons and spinners are modest in size and simple in construction. Only single hooks are used, but they are so well constructed on right lines that they worthily

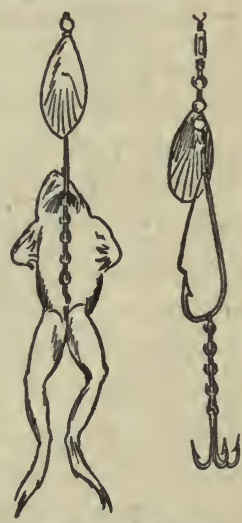

Freeport frog hook.

Single find a first place in the hearts of every
Hooks angler. The trout tandem is an excellent lure, sure and safe, spinning perfectly easy each way, slipping through the weeds and working to perfection.

Pflueger's Tandem spinner with speckled Tandem guinea-fowl's feathers is a lure that is Spinner necessary to every angler's outfit. 'The Wilson spoon, of suitable size, with the bent tip, is also a prime favorite for all kinds of game fish. 


\section{Fish and Fishing}

In the Freeport frog and minnow hook we have a later device, which has quickly found a host of friends; the treble-hook chain attachment being a never-failing trap for the wariest and largest fish; there is no doubt of its holding tight as well as luring them. One interesting new feature is that it is colored blue. I believe it is the only one of that color on the market. Of its effectiveness, both as a weedless lure and an attractive one, every angler who has used it, bears witness.

\section{TROUT}

\section{WITH THE FLY}

The legitimate methods of fishing for trout are fly-casting and worm-fishing, with a light rod and delicate water gear. I am pleased to quote the late Wm. C. Harris who says: "I am not so ironclad in my opposition to bait-fishing for trout, Methods as are many of my brother anglers. It is an art in itself, and a knowledge of the habits of the fish and of the stream in which it lives is as necessary for success as it is in flyfishing." To this I fully agree and therefore often practise it.

Fly-fishing for trout is followed by the great majority of anglers, and their methods of fishing a stream are somewhat diverse; but all agree that in slow-moving waters the best course is to fish up stream, and in swift running ones, down stream, making a détour when a likely pool is 


\section{How to Get Them}

reached, fishing from the lower end to its head. In fishing up stream the cast of flies comes quickly down on the current, but this can Up and Down be partially avoided by directing
Stream the flies diagonally up and across. On bright days and in low water trout are timid, and in the latter part of the season leave the shallows, when the sun is up, and go under a large rock or bank on the shady side. On dark days and at night-time trout, as a rule, rise more freely. Trout in a current always poise with head against it, and are less likely to see the angler below them than when he is fishing down stream. If the water be agitated, either by wind or pebbles at the bottom, it disturbs the acuteness of sight Windy of trout. In a brook of dancing and rippling water, falling over numerous obstructions, wind is a disadvantage unless it blows in the direction of the cast. To cast against the wind it is necessary to use great force, and immerse a large portion of the line in the water, especially with very light line and leader, so that it is best to limit operations to the pools.

If conditions are ideal and trout are taking the fly readily, make the most of your time; fish Quickly smartly, take the trout off the hook and quickly, walk over intervening ground basket them as speedily as possible. As long as you are fishing do it as if you expected a rise at every cast; many a good fish have I lost in an inadyertent moment. If you are tired, or the trout are not taking, sit down and 


\section{Fish and Fishing}

smoke; fly-fishing and smoking hardly fit. All beginners in the art of fishing, if they wish to excel, should commence in streams where the trout are remarkably shy, and they will thus sooner become skilful. If they commence in private, well-stocked streams, they will get into a careless style of fishing and be ill-tempered on a well-fished stream, where they ply their lures to the terror and alarm of almost every trout in the water, and return, if not with an empty basket, at least with a very light one, with the excuse that the water is too clear. Perhaps the easiest of all fishing is the small mountain Brook brooks. It's a matter of choice to fish
Fishing up or down. If down, the flies can be guided thirty feet ahead and run to every nook and corner, practically without casting at all, the force of the current doing most of the work. In fishing up, however, the case is different; repeated casts are required. I have done both and the catch is about equal. Fishing up is certainly harder work, both in wading and casting; much depends upon the water. I like better to fish home than to fish away; in the latter the long walk back is not so agreeable as to end, with a full basket, right at my temporary home.

Before I reach the stream to fish my fly-book is prepared with half a dozen leaders with the flies attached, so that all there is to be done is to tie the cast to the line. It is better still to have the prepared leaders in a small round flat box, arranged between layers of damp blotting paper. In this 


\section{How to Get Them}

way the gut is wet and the flies are out straight at the first cast. By this means time is saved and put to better use when needed. This method is invaluable at dusk, when it is difficult to see and to tie good and fast. Three flies are placed on a six-foot leader, and you will find loops to be a decided Prepared advantage-quicker to change, and not
Casts easily fraying the line, as when the fly is tied to the line proper; then again, both dropper and second fly work away better from the line. Some anglers use a nine-foot leader, but I find it too long in the act of landing fish; while in the water, it is difficult to lead the fish to the net. It is not possible to reel the knot (where the gut is fastened to the line) past the tip. At least, it is not a wise thing to do if you have a large fish.

Approach with caution and step quietly into the stream, either in the boil of a rapid, or on the shallows near the bank. Never step into or near a pool, but cast first short distances, especially around large rocks where the eddies swirl by, thereby making bubbles in a line from it. Un derneath those bubbles lie the fish, rising at times for the flies floating down. These are mostly dead flies, and a black-winged fly should be on the end of the cast because more easily seen. It very often happens that you scare away a big one just as you get in the water. On the following day Quietly start in at the same place, but give a few casts without being seen at the edge, to get that same trout; it's more than likely to be there, and if in the humor it will take the fly offered. 


\section{Fish and Fishing}

I must constantly repeat, trout are shy. I know a pool, the shady side of the river being high rocks and impossible to fish from, which contains a nice lot of big trout, having a complete range of over a hundred feet. They would never rise while the angler was in sight, and the cast was too far because of branchy trees. I floated the flies down by the current, and so got them in that way, but not till I had fished in vain many times; seeing me there casting, they refused to rise.

In ideal rivers, wadable from the middle, like the Beaverkill, N. Y., the cast may be placed all over the stream; cast first one side, letting it go to the middle with the current, then a River Fishing

new cast on the other side, then move forward a few yards; it is impossible to wade up such a stream of swift water. If you want to fish up, the only way is to cast from the sides, and this may not be possible in the best places because of foliage lining the shore.

Casting the fly at night-time, unless the water is familiar, is unsatisfactory work, even if fish rise well; the line is apt to get entangled and the flies, because unseen, may be all twisted up; a similar trouble is found in playing and landing. The choicest half hour of the day, of course, is from sundown to when the stars appear. Then the true angler is busy and every cast Night-Time made to count; and you may be excused if impatient at playing the fish, when others are rising and plopping all around. At such times a black fly and white fly are neces- 


\section{How to Get Them}

sary. Every angler finds the coachman the favorite evening fly, but to my mind, the black gnat is equal. Water flies are more on the wing at might than at daytime; that is the sole reason why the trout rise better, for trout have no mind to go hungry.

In fishing a trout stream, the same flies will lure and be suited to nearly all the trout and charrs. I have taken a mixed basket of brook trout, brown trout, rainbow trout, on Use Few the same cast of flies; large variety of
Flies flies is unnecessary. Thad. Norris said, forty years ago: "Don't bother with a lot of flies. Here are four that will serve all purposes: one is the red spinner, the second a black gnat, the third is the coachman, the fourth, and best of them all, is the red hackle." I consider this today a good selection, though much depends upon the size; they must be small, smallest in hot, bright sunshine and low water, larger at evening and on dark days. But I have for these last two seasons used nothing but four flies of my own invention, tied, at my request, by Abbey \& Imbrie, N. Y. Some of my friends have tried them with pronounced success. I had a theory that a metalbody fly would be more killing, and be seen at

a greater distance; because of the flash Metal- of light moving through the water from Flies either silver or gold, though I find silver more taking. The best fly was a silver body, gray wings, black hackle and tail; the next best, a gold body, with brown speckled 


\section{Fish and Fishing}

wings, reddish orange hackle and tail; another, with silver body, black wings, gray hackle and tail, and the last had silver body, white wings, gray hackle and tail. These four flies gave such good account of themselves that my friends and I are content to use no others,' at least until they stop raising fish. These flies are tied upon a No. 8 Pennal sneck hook. To rise trout and hook them, I strongly and firmly believe size has more efficiency than color of wings; and a No. 8 hook, or even smaller, works the trick from spring to fall (that is, in running streams). Lake fishing is an-
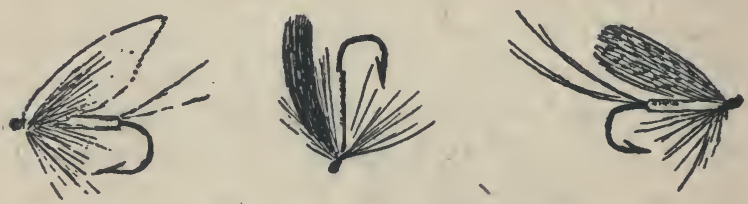

Exact size of author's silver and gold body trout flies.

other matter, and will be treated separately. Rules cannot be rock-bound, as you can always regulate the color of flies by practice, Size and and my practice has proved beyond doubt that black, brown, and graycolored flies used together and varied in size according to circumstances, will at any time kill as well and even better than the most elaborate collection arranged for every month in the year. If you have the three colors mentioned you cannot be far off the mark, as they comprise all the leading colors of insects in nature. A white fly is of 


\section{How to Get Them}

great value at times, though a black fly is seen at night just as well by the trout, but not by the angler.

My great objection to the flies offered for sale is that they are much too large and bushy for clear water. Every possible advantage is in favor of a lightly dressed fly; it is more like Avoid Bulky the natural insect, it falls lighter in
Flies the water, and the hook is not so covered with feathers as to stop it from getting a good hold.

In addition to the above four flies, I think it wise, nay necessary, to have a cast of hackles or spiders of black, brownish red, ash color, or gray. In the summer months, when trout are lazy and well fed, or much fished and very shy, the spider will be found more deadly than the winged fly; so that if the leader be a gray-winged fly, remove it Hackles and put on a gray hackle or spider of the same size. The reason is that the hook is better concealed, and if the fly is made of soft hackle the water agitates the feathers, giving them a life-like appearance. If the trout will not take a gray hackle, try the black, and afterward the brown. In case all these fail, give up and go home.

For brilliant primary colors (red, yellow, and blue) I have no use, having long since given them away to inquisitive strangers on the Brilliant stream who ask what fly I got it on.
Flies Nothing is more exasperating than to be expected (even by friends) to give one's taking flies, especially when the supply is getting low. 


\section{Fish and Fishing}

On the stream, neither borrow nor lend. If you are a true angler you will amply provide yourself; if not, patiently wait till you can resupply. The careless angler must be taught a lesson in providing his wants, not encouraged to depend on others to whom they are rarely grateful.

The art of dry fly-fishing is a beautiful and
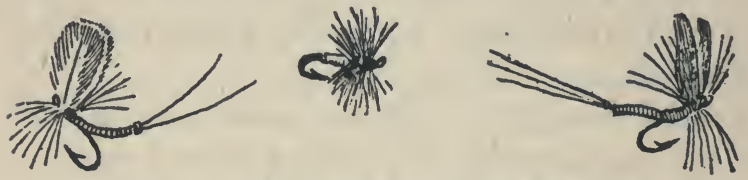

Exact size of dry flies for trout and grayling.

highly scientific branch of angling, which has been practised on English streams for some time, and is yearly coming more into favor in our Dry Fly- own country. It is only possible here to give a slight inkling of it. To get a thorough knowledge of the science the reader should consult the works from the pen of Frederick M. Halford. It consists of casting a " single" fly, perfectly dry, upon the surface of the water, and floating it passively down stream over a rising fish, instead of submerged, and guided hither and yon across the current. The flies are made specially with cocked wings, and are exceedingly small, yet more like nature than the average wet fly. They Method are marvels of neatness and sombreness, deceive any fish, particularly large ones. The angler is supposed to cast only when the fish are 


\section{How to Get Them}

visibly feeding. He then selects his fish, gets behind it (that is, below it), and prepares for a cast. Then taking two or three false casts in the air to judge the exact distance, the fly is thrown with the intention of making it alight gently a foot or Casting two above the rising fish, and exactly in his line; for a well-fed fish will rarely go even a few inches out of his way for a passing fly. If the fly falls short or wide, it should be left till the line has floated some distance to the rear of the fish, when it must be picked off and whisked through the air two or three times to dry the wings and hackle before a new cast is made. To succeed even moderately well requires a vast amount of practice; clumsiness and bungling are fatal and put the fish down, and it stops feeding. If the fly comes down exactly in the right spot, the fish takes it, if not, the glittering gut arouses its suspicions and it does not fall a victim to the angler's effort. A most important part of this science is to recognize readily the fly on which the fish are Flies feeding, and be able to match it with a good imitation. The most famous flies are olive dun, red quill, red spinner, jenny spinner, black gnat, and the alder. .

The art of dry fly-fishing is of no advantage when fishing down stream in wild water; its success is when fishing from below a quiet, deep pool.

The tackle is exceedingly light, and the gut at least nine feet long; and the point to be attained is to make the fly drop on the water, float upright on the surface for a few seconds (as the natural 


\section{Fish and Fishing}

fly does), and then take it away again without going under water. The use of dry fly-fishing may be brought in play for any of the trout and charr, if the water is suitable. It is, of course, more valuable late in the season, when the water is low and the sun bright. Dry fly-fishing should not be attempted by any but expert casters; the tyro had better be content with wet-fishing, which, to do thoroughly, requires many years' study and practice; indeed, it is quite sufficient for all the streams I know, and they are many. English streams where the art is practised most are the Test and Itchen rivers. The water is slow, deep, and very clear; they are.over-fished and the trout are pretty scarce.

\section{CASTING THE FLY}

FOR TROUT

Casting the fly for trout is the most delicate and refined art in the range of sport. The quickest and best way to become proficient is to use patience, and observe an experienced fly caster on the stream. First, bear in mind that the rod has to do far more work than the arm; in fact the arm, except in very long or peculiar casts, does very little. In preparatory practice the novice should have a six-foot leader on which is tied a single small hook; attach to the hook a small piece of white rag, an inch square, fold it on the hook over the barb, then draw about eight yards of line off the reel, and 


\section{How to Get Them}

force it out as far as possible. If practising on a lawn, it is necessary that the gut be stretched out straight so that it will throw propLawn
Practice erly. Place a mark eight yards away and aim for it. Raise the rod-point - a little, and when the rod is at an angle of about forty-five degrees, by a wrist movement bring it sharply back on your side. Check your arm an instant as the rod points nearly straight up above the head, and the line will then fly out behind; then again using the wrist, bring the rod rapidly forward from the upright to the angle of forty-five degrees, avoiding anything in the nature of a jerk, and check it. The line will fly out in front of you, and, if not a long one, the end of it will come to the ground or water (if on the stream) before any other part. In these quick movements of the wrist the chief difficulty of fly-casting lies, and

Wrist Movement

it is not until we have used a fly-rod for some time that the muscles of the wrist become properly developed and we acquire the knack of casting well. Give full time for the line to get out behind before making the forward cast. In the overhead cast the rod points only a

Overhead Cast trifle to the right when the back cast is being made, and is almost upright when the forward cast is in progress. The underhand, or horizontal cast, is very similar to the overhead cast, the only difference being that in lieu of the rod being kept for the most part upright, it is held in a horizontal position, that is, in line with the earth. But it can only be 


\section{Fish and Fishing}

practised when the ground behind is flat and clear. One advantage of it is that the rod being Underhand Cast held low is not seen by the fish. If you fail to cast lightly, aim at an imaginary point in the air two feet above where you wish the fly to fall. When the overhead cast and underhand cast are mastered, the angler should try what is called the steeple cast, which is sending the line as high in the air as possible when making the backward cast, the forward cast being made as before; by this means a very long line can be got out,

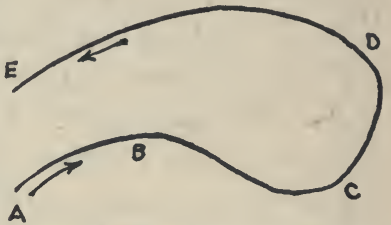

Curve followed by rod-point in spey cast.

and the line is not so likely to catch impediments behind the angler. There is still another method Spey Cast called the switch or spey cast, most useful where, owing to high banks or trees, the line cannot be extended at all behind the angler.

It is necessary to fish down stream. We are looking down the river with a rock behind us, our rod-point is rather low, pointing toward the fly, and our line is extended down stream. Suppose our rod-point is at A, we raise it smartly, following the curve shown to $B$, when our line will be off the water: then we depress it again to $C$ and raise it to $\mathrm{D}$, by which time the fly and a portion of the line will be touching the water almost at our feet; then we switch the rod forward sharply 


\section{How to Get Them}

from $\mathrm{D}$ to $\mathrm{E}$, and the line follows round in a curve, leaves the water, and rolls out down stream in front of us. The progress of the rod-point from A to D must be steady and rather quick than slow; but from $\mathrm{D}$ to $\mathrm{E}$ it can hardly be too quick.

The angler, having acquired some proficiency in casting from his right side, should next practise casting from his left side, still Left Hand Cast holding his rod in his right hand; and if he can bring himself also to cast well with his left hand, he will find his accomplishment most useful.

In fishing a river, on all occasions cast the fly about a yard above where the trout are likely to be found, because, if on alighting it attracts their attention, there is much less chance of their discovering its artificial nature at that distance. For the same reason, if a trout rises at the natural On the fly, throw beyond it, and in general it will
Stream meet the fly half-way. If a trout rises to the fly without taking it, cast again, and continue doing so till it ceases to rise. A small trout will frequently rise four or five times in succession, but the large, well-conditioned fish are more wary; if they miss once they usually decline to return, however temptingly the fly is placed before them. The line must be so thrown that the flies will fall first upon the water, and as little of the line with it as possible. In fishing nooks, eddies, and still water, at the opposite side of the stream, if any of your line lights in the current, it is dragged down, and the flies no sooner touch 


\section{Fish and Fishing}

the water than they are drawn rapidly away in a most unnatural manner, and without giving the trout time to seize them should they feel inclined.

In order to make the flies light first, considerable force must be employed in casting; the rod must be kept well up. It is upon this point beginners fail. Their unavailing efforts to get the line well out are entirely owing to their allowing the point of their rod to go too far Drop Flies down, and to their stopping it too
First quickly, which makes the point recoil, and stops the line in its forward motion. When the flies are just about alighting on the water, you should slightly raise the point of the rod; this checks the downward motion, and they fall more softly.

Throw a long and light line when fishing down stream, so that the angler is not seen; fishing up

Cast Far Down Stream stream a long cast is not so necessary because their tails face you. In contradistinction to the maxim of throwing a long line, never use a long line when a short one will answer the purpose. If too much line touches the water it is impossible to make the flies light first. A long line is also very difficult to cast neatly behind stones or under a bank. The greatest objection to it, however,

Easier

Striking with Short Line is its disadvantages in striking a trout; it lies curved in the water, and when the angler. strikes, it is some time before the flies move, and then without much force; with a shorter line, the least motion 


\section{How to Get Them}

of the hand moves the flies immediately. The nearer we are to our flies, the greater is the chance of hooking a trout when it rises. It is of greater importance to make the flies light softly in a natural manner, like an insect with outspread, gauzy wings.

To accomplish this and to throw with certainty to any spot desired requires great practice. Thin gut, the necessity of which I advocate so strongly, is exceedingly difficult to cast, as it has little weight to carry it forward; therefore beginners should use moderately strong gut at first, and as they improve in casting reduce its size.

\section{PLAYING TROUT}

Opinions differ as to whether a trout should be struck on rising, but my experience is to strike at once. When a trout takes the fly it shuts its Striking mouth, and is therefore almost sure to bring the hook in contact with its closed jaws. It frequently happens that a trout on taking the Hy, when left to do as it chooses, very quickly expels it from its mouth with considerable force; a trout on seizing an artificial fly is almost instantaneously aware that it is a counterfeit and never attempts to swallow it, but very frequently lets it go before the angler has time to strike; so that it Quickness is of the utmost importance to strike immediately, and this is the reason why a quick eye and ready hand are considered the most necessary qualifications for a fly-fisher. 


\section{Fish and Fishing}

A trout first takes the fly, then makes the motion which the anglers term a rise, and which consists of its turning to go down; the angler, therefore, does not see the least break on the surface until the trout has either seized or missed the fly; so that he has already lost so much time, and should strike at once. Though it is impossible to strike too soon, it is quite possible to strike too hard. Striking should be done by a slight but Wrist Motion quick motion of the wrist, not the arm, and always in the same direction as the rod is moving at the time. The effect will be more immediate at a moment of the utmost importance. It often happens in quick striking that the trout misses the fly; in that case it is pretty certain it will rise again, or others will take its place. If the hook has pricked it, that is the end; at least for that day it never rises, but stays below, even if the fly is changed.

At the first heavy surge, if it is a large fish, make no attempt to check the reel, but have full command over it. At this moment I always place the butt of the rod in my left hand and take charge of the reel handle with my right hand, as I am able to reel in quicker. Many anglers will differ from me in this, preferring to hold the rod all the time in the right hand, and to reel with the left; either way will do. More strength is required to reel in than to Hold Rod Up hold the rod. At all times keep the rod tip well up in the air and the line as taut as with safety can be. If the trout suddenly turns toward you, reel in as fast as 202 


\section{How to Get Them}

possible; don't attempt to pull the line in, so that it falls down in the water. It is sure to get entangled in the stones at the bottom or your movement will be retarded by getting the line round your feet. If the fish makes a sudden leap, lower the tip at the same time, about the same distance as the leap from the water; as it goes down again, at once have the tip up back in place. This move is important; if not done to a nicety the trout gets off, and the cast comes flying back toward you.

A trout is sooner subdued if worked down stream. When a large trout is hooked, and it cannot be pulled on shore at once, pull it down stream, as the current is in the angler's favor and will choke the fish sooner. But keep the rod up to exhaust its fighting powers. Never let the line out far if it can be avoided. It is obvious that with a short line better command over the fish is attained. At no time let the line be Keep Tight slack; if it is, and the hook is not
Line securely fixed, but merely resting on some bone (a thing that frequently occurs) the trout will throw it out of its mouth. Should the trout be a large one and the cast of flies small, wade down stream, or better still, work toward the shore; then, walking swiftly, follow the fish till its fighting gets less and less. If the edge of the stream be unfavorable for beaching it, the hand net is the only sure way to land it. Reel up the line as far as possible, even up to the six-foot leader; then with the rod lead the fish toward the net, which always should face the trout; it should go in the 


\section{Fish and Fishing}

net head first, and then be swiftly lifted out of the water.

I have lost many trout trying to basket them while standing in the stream. It is next to impossible to hold the rod and net, and at the same time get the fish out of the net, unhook it, and place it in the creel; for that reason get ashore with the trout in the net, and lay the rod down to have freedom. in unhooking.

Before returning to fish, examine the cast, see that the flies are secure, and the gut in order and not tangled.

As soon as the fish is unhooked, hold it tightly and rap it hard just over the eyes on stones or some hard substance, so that when placed in the creel it will not kick or move about after you have returned to fish.

\section{HOW TO GET THEM WI'TH LIVE BAIT}

\section{TROUT AND CHARR}

Spinning and trolling are chiefly carried on in large lakes, where trout do not rise to the fly. The lake trout come to the surface very early in the Lake Fishing spring, and the angler trolls for them on or near the top of the water, the fish taking the lure viciously, but rarely jumping into the air. The proper tackle for surface trolling consists of a very light sinker, a twelve-thread cotton line; a No. 5 spoon from which is taken all the gang hooks and a single No. 8/0 hook substi204 



\section{How to Get Them}

tuted, the latter to be attached to the lower end of the spoon by a snood six or eight inches long, a good multiplying reel, and an eight-ounce rod, not longer than nine feet. The bait should be a golden shiner or any other carp-like

Surface

Fishing with Minnow

fish; a large one of six or eight inches, if the trout run big, is most seducing to them. Many anglers do not use the spoon, relying upon the attractiveness of the natural bait, though the revolving

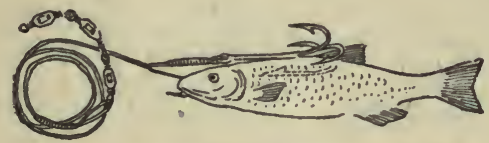

Shiner baited on St. Lawrence gang.

wings of a bright spinner draw the attention of fish to the bait from a long distance; when they reach it, they take the minnow voraciously, seldom striking at the spoon.

The deep-water troll requires more elaborate tackle than that used in surface fishing. Attach a cone-shaped sinker to the end of the reel line, from three to sixteen ounces in Deep=Water weight, the size being dependent on
Trolling the character of the bottom and the style of fishing preferred. Use a long or short line; if the bottom is jagged in shape, the line should be strong and the sinker comparatively small. The same holds good on smooth bottoms when fishing "slow and far off"; if you prefer fishing with a short line, the sinker must necessarily be heavy. 


\section{Fish and Fishing}

You will need no rod; the line held in the hand will enable you to be more sensitive to the slight-

Find Rapid est touch of the lead on the bottom, Depth which you must feel, as your boatman rows slowly and regularly along. If, however, you wish to use a rod, lay it

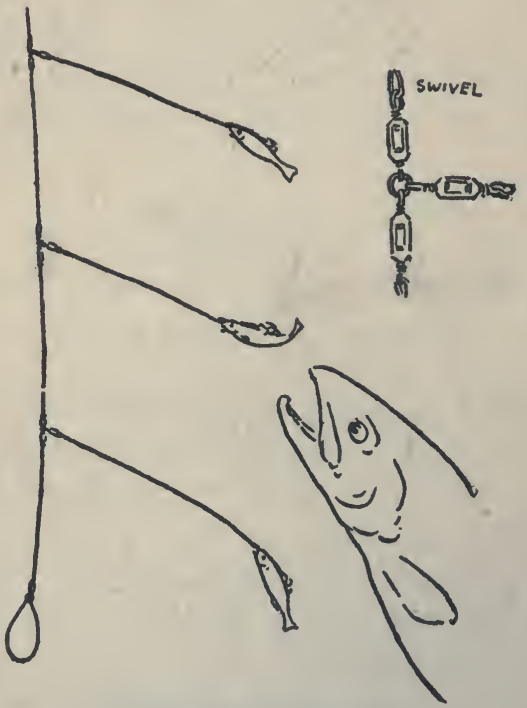

Trolling rig for lake trout.

down within reaching distance, holding the line, and when you feel the pluck of a fish, and fasten it well, take up the rod, being careful to keep the proper strain on the fish when lifting the rod. Three feet above the sinker attach a single or double-twisted leader (the average weight of fish that are feeding should determine its size) and 206 


\section{How to Get Them}

two other leaders placed above the first, from six to ten feet apart, the distance to be judged by the depth at which the lake trout are taking the bait. A gang of three hooks is usually placed at the end of each leader, but a lip hook and another larger are to be commended as more sportsmanlike. Place swivels wherever needed, and let your sinker line be three feet long, and weaker than the reel line, so that in case of getting hooked, among bottom rocks you will only lose the sinker. Bait'with a large minnow as suggested in surRow Slowly face trollabove all things have the boatman row slowly along and with a cadenced movement. The secret of success is

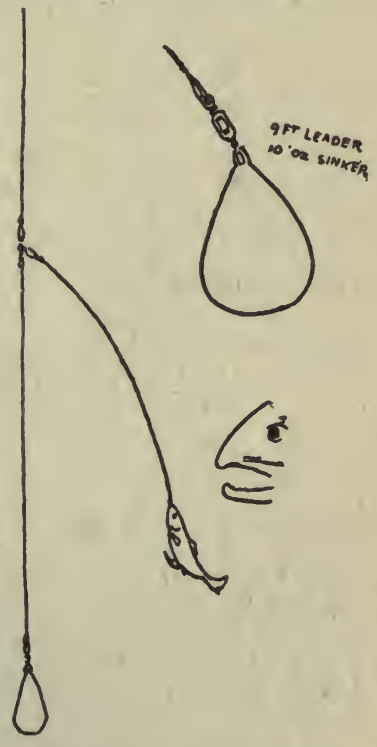

Trolling rig for lake trout. proper speed, the right depth, and place. As a rule begin fishing late in the afternoon till dark.

The best condition of water for capturing trout (of large size) is when there is just sufficient rain to raise the water slightly, and make it of an amber color. When a large flood occurs it scatters the trout too much, and they become gorged 207 


\section{Fish and, Fishing}

with food of every description, and do not take bait so readily; so that more trout can be caught, Flooded as a rule, in clear water than after a heavy Water flood. If the water is only colored or

slightly swollen, trout will be found in the same places as when it is clear, but when the water is high and dark-colored, it is of no use Rivers fishing the stream, as it is too rapid, and the trout are all congregated in the pools about the sides. In such circumstances fish the sides, fishing the side you are on straight up and as close to the edge as possible, and the opposite side partly across and partly up, as usual.

\section{Fish the} Sides

The greatest number will be frequently got on the thin side, but the largest and best trout are almost invariably caught on the deep side and very close to the edge. Let the worm sink, and allow the current to work it about, close to the bottom. When the angler chances on a spot where trout are plentiful, he should remain there, casting in different parts of the pool. The largest fish in the river are often taken with worms during a spate.

Worming in clear water is carried on when rivers are at their lowest and brightest; in hot months, when fly-fishing, except at night, is next to useWorm=Fishing less. For this method the fly-rod, and reel may be used, the gutcast at least nine feet long. Some anglers use a three-hook tackle, some prefer two hooks, and some declare a single hook is far the best; of the latter I prefer that shown in cut. For the preparation and 208 


\section{How to Get Them}

variety of worms, see "How to Get Them on the Worm." If wading, cast up stream; make a bold sweep of the rod without jerking the worm off the hooks. When the worm touches the water, the Cast rod-point should be slowly raised (faster if the stream is swift-running), till the worm is carried by the stream within a yard of the angler; then bring it out of the water with a back sweep of the rod. Keep as little

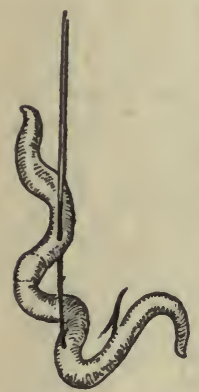
line in the water as possible, and watch the line carefully, for the only evidence of a bite is the stoppage of the line. Endeavor to lead the worm round large bowlders, especially on the shady side of them, for there, to escape the Double hook. hot sun, lie most of the

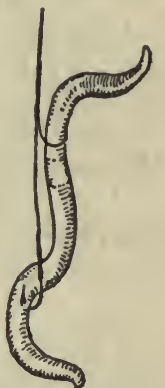

Single hook.

large fish during the day, generally off feed. Keep as much out of sight as possible; if they see you they will not take the bait, but Keep Out lie there.till you nearly tread on them,
of Sight when they suddenly dart off.

Worm-fishing in lakes or ponds is rarely practised as it is the least interesting in such waters. It is most successfully practised from the shore, wading, if feasible, and casting out as far as possible. The best time is in the morning, and better, if there is a breeze rippling the surface. When any river which enters the lake is in full flood, 


\section{Fish and Fishing}

large trout may be captured just outside of the place where the muddy water becomes mixed with that of the lake. The use of a boat Worming in Lakes
in advisable, and the angler then can row around, throwing his bait into the stream, which will drive the bait toward him in clearer water. Trout congregate about the mouth of a stream to get the food which it brings down.

Minnow fishing requires the exercise of much presence of mind. A large trout makes a glorious rush at a minnow, and it requires both skill and Minnows $\begin{aligned} & \text { coolness in order to secure it. Like } \\ & \text { other methods of angling, minnow fish- }\end{aligned}$ ing in discolored water is comparatively easy, but when the streams are clear, to fish successfully with the minnow, particularly in small waters, requires great dexterity and is one of the most difficult operations of angling. The largest trout taken by the rod are usually caught with the Trake Large - minnow. Trout accustomed to prey upon their neighbors usually attain a great size, and are more likely to take a minnow than anything else. A minnow measuring about an inch and three-quarters, tail inclusive, is the size for trout, at all seasons, in running water. A large trout will take a small minnow as readily as a large one, a middle-sized trout more so, and a small trout which could not take a large minnow will take a small one. When the water is low and clear it cannot be too small, if it turn the swivels. A large minnow spins in a clumsy, un- 


\section{How to Get Them}

sightly manner, only inviting when the waters are flooded. Trout can also get hold of a small minnow much more easily, so the angler has a much better chance of hooking them. With regard to the number of hooks of which minnow tackle should consist great diversity of opinion exists, but two hooks with a drag behind will kill as many fish as any other combination. The following cut shows the minnow tackle.

In baiting take the large hook, and, entering the point at the mouth of the minnow, run it

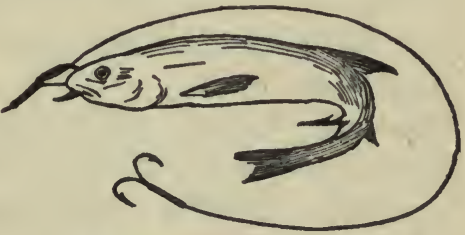

Two-hook minnow spinner. right through the body and bring it out about a Hook Baiting quarter of an inch from the tail, leaving the minnow as nearly as possible in the curve shown in cut. The object of the curved form is to have it turn round when drawn against the stream. The upper hook is then stuck through the lips. The angler should, before fishing, draw it through the water to see if it spins properly. Two swivels should be used to prevent the line twisting, and split shots Nos. 2 or 3 should be placed above the first swivel, about two feet above the hook, the second, a Flooded yard farther up. The mode of fishing
Water flooded water is to throw the minnow across the stream, and work it gradually around, pulling it up from the water a foot or so, then let- 


\section{Fish and Fishing}

ting it fall back again, and so on, till it comes round to the side on which the angler is standing.

It should be subjected to every variety of motion, one cast drawn steadily against the stream, and the next with short jerks across it. Great care should be taken not to lift the minnow out of the water till it is quite close to the edge, as trout frequently follow it. When a trout has taken the minnow, slacken the line for a moment or two to allow it to get fairly in its mouth. Then the angler should strike firmly.

Trouting with the minnow when the waters are clear is much more difficult. If the water is deep, the minnow should be well sunk, as it spins better. In large streams the necks of pools, rapid broken water, detached currents, and smooth and strong water at the foot of pools are in general the best places. In small, clear streams it is In Clear better to dispense with the sinker, as it drags the minnow to the bottom and splashes too much, and the most likely places for success are where the stream runs beneath a bank. The method of casting is the same as in rough water, but keep the rod perfectly still and remain stationary while fishing each spot.

\section{ON THE WORM}

Fishing with a worm is not held in such high estimation as it deserves, a circumstance entirely due to its being but very imperfectly understood. Fly-fishers are apt to sneer at worm-fishing as a 212 


\section{How to Get Them}

thing so simple that any one may succeed in it. Yet a live worm is the most effective, deadly, allround bait available; for all the fish that swim, either in fresh or salt water, from the plebeian and lowly catfish to the lordly salmon, at all seasons, daytime or night time, it is resistless, and bound to be seized with avidity, especially if properly impaled on a hook which is of the right size. Nature's bountiful provision of an inexWorm a haustible supply makes the worm a Provision poor man's friend. No matter where he digs in suitable soil, a few minutes will suffice to amply supply him with all that is needed to capture and provide a mess of fish for himself and his family. With the aid of a small hook and some fine line, costing a few cents, when used with care and judgment, he will be as successful as the rich man with expensive tackle and fly book. Of course, the highest art in worm-fishing is that practised by salmon and trout anglers, not the ever-present worm plugger of mountain brooks, but the expert, who captures the wary trout in low and clear water during June and July. One advantage it possesses over the fly is the superior size of the trout caught. It is just as important that the bait be properly prepared, that the angler may succeed in landing more fish of larger size. In using worms for chub, dace, perch and wall-eye, and sunfish, there is a great advantage in having them well scoured and of proper size. There are four kinds of worms most esteemed by anglers. The 


\section{Fish and Fishing}

black-headed worm, found in good garden soil, is free from the knot which most worms have, and

Varieties of Worms is rather dark in color. It is the most durable of all worms. Then there is the brantling, found in old dunghills or similar places. It may be known by its rings, with a knot a little above the middle, and it is somewhat flat. One objection to it is its extreme softness. It is incapable of being toughened. The marsh worm, when taken from the earth, is of a pale-blue color with a whitish knot a little above the centre. It is a very small worm, and when kept long enough becomes a lively pink color and most killing for dace, sunfish, and chub. It is the most plentiful, and may be found in any garden among heaps of decayed rubbish or leaves, and below stones. The red-headed worm is only found plentifully in the very richest soil about the edge of dunghills. It is thick in proportion to its length, and is a darkred color down the back, pale blue underneath. It is not so good as those before mentioned because it soon loses color after being a short time in the water. It is best suited for perch, wall-eye, and eels.' A small, bright, clear worm is always more enticing than a large, thick worm. It is a great error to suppose that a large, thick worm insures the capture of large-sized Small Worms the Best fish; it is quite the reverse, as a large worm will seldom capture anything but some audacious little fellow. When worms are newly dug they are so full of earth as to 


\section{How to Get Them}

be unfit for use. Brantlings may be scoured in a day or two, but the other kinds require to be kept at least a week. Immediately on being dug they should be well washed in clear water and placed in an earthern-ware jar with plenty of moss. The moss should be well washed and wrung as dry as possible, and all the sticks and straws picked out, as they are apt to cut the worms. The jar should be examined every second or third day, and all the dead or sickly worms removed, the moss changed, and a few small pieces of bread and a spoonful of milk put on the moss for their nourishment. The process of toughening worms can only be accomplished by keeping the moss dry, so that the worms may lose some of the moisture of their bodies and thus become Kept in tough and more durable. Of course, if
Moss carried to any great extent it impairs their vitality, which gives them a withered look. When thoroughly divested of earthy matter worms can more easily be baited and will last quite a long time alive for the purpose needed. It is important that the worm jar should be kept always in a cool place. For eels and catfish there is no need to use scoured worms, but for chub, dace, trout, wall-eye, sunfish, perch, the two latter especially, they are of great value, and it is also well to choose the right kind of a worm. The redheaded worm is best for perch and wall-eye. The brantling is better for chub, dace, and sunfish.

When impaling the worm on the hook, it is not necessary to pierce the hook through the middle 


\section{Fish and Fishing}

of the body, but it can be, and is, quite sufficient to hook it just through the skin; it will hold if Hooking the barb is sharp. In that way the Worms

worm can act much more lively while in the water. It is the lively kicking movement that most attracts the fish. A dead worm is of no value to tempt a fish. Be careful to remove little bits of white remnants of previous worms. They should never be left on the hook.

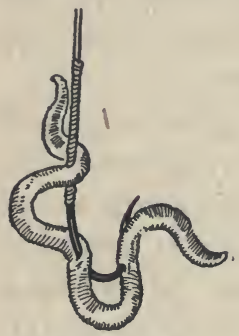

Way to hook a blood worm for saltwater fishing.

No scouring is needed for the sand and blood worms for saltwater fishing, but they should be kept at no higher temperature than their natural element of mud or sand. They are kept longer in sea leaves or weeds, just kept damp and cool; the sea-weed contains sufficient salt to retain their freshness. Many, indeed most saltwater anglers put the hook right through the middle of the body, and so let out all the blood, which, of course, takes life away with it, and all that remains is a white piece of tape on the hook, not nearly so attractive as the natural, Marine wriggling worm. Any fish whose mouth is large enough to take a blood worm takes the hook right in its mouth, so that it is much better if the worm is hooked by the skin, first at one end, then in the middle, also at the other end; by this means the worm lives, acts in a natural manner, and is more attractive to the 


\section{How to Get Them}

fish, drawing them to the bait much sooner, and enticing them to take it with greater avidity. Blood and sand worms are quite long enough to allow at least an inch of each end to hang down and wriggle.

There is one disadvantage in hooking them by the skin because smaller kinds than those fished for are apt more easily to tear the bait Hooking off and so get away with it; but I find
Them that this happens less often than might be supposed, for the larger fish drive small ones away when they see a kicking worm.

When no other bait is available, the large night walker is very effective in running water just before dark, both for bass and pickerel. It should be hooked by the skin and allowed free play, wriggling as it runs with the water, behind rocks and stumps. It is also just as deadly with the salmon, but for the latter a few shot put on the leader to keep it below the surface will be needful. For big trout, lying low in deep Wig Night pools, more particularly the brown trout, the worm should be sunk to the bottom; it is sure to be taken quick, if the worm is actively alive. Of course, suckers, eels, and other vermin are liable to take it, if left in one position for any length of time. To prevent such annoyance, keep it moving, a yard or so every few seconds, not so violently as to scare the fish.

In mountain brooks, where fish are rarely over ten inches long, the smallest hook and the smallest worms should only be put in use, and only one 


\section{Fish and Fishing}

worm at a time. There are often difficult eddies where the worm cannot be placed because of overhanging trees or side bushes. To obviate such difficulty, take hold of the hook shank with about the desired length of line out, and hold the rod out, then let go the hook shank and the force of the bended tip will flirt the worm to the desired spot. After a little practice in Worm worm flipping the angler can expertly place the bait within an inch of any spot required. Many little round spots of foam are formed by the eddying swirls, mostly in places impossible to get at except by this method of flirting the bent rod. I use it often with advantage in fly-fishing by just holding the end fly and flipping it to places that could not be reached in any other way. 


\section{CHAPTER VII}

\section{When to Get Them}

\section{TIME OF DAY}

In regard to the best time of day for angling, a great deal depends upon the temperature of the water, the season of the year, and the kind of day; though as a rule, fish are sluggish and off their feed during the middle of the day. Only for bait fishing are the very early morning hours good; on small streams, about sunrise is often the best hour for trout, bass, and pike. On large streams and

Early lakes nothing is gained by early fishing, Morning as the fish do not bite well until the sun is several hours high. This question of early hours has long been misunderstood. It is better to wait till the sun is up, for most fish feed all through the night. Predaceous fishes are more active during the night, while the smaller fishes, minnows, etc., are more active during the day, keeping in very shallow water during the night to avoid being swallowed by their larger congeners.

In the first part of the season of salmon fishing 219 


\section{Fish and Fishing}

any time of day is good except early morning; taking it all round, from 5 P.M. till dark is better than all the rest of the day. Worm-fishing for trout is good from two hours after sunrise till dark, and after dark, in the early season. The same can be said of fly-fishing. On cloudy days the middle of the day is best, especially on large Mid=day lakes and rivers. On hot midsummer days the middle of the day is poor for bass, trout, or pike, but good early and late in the season, when the water is still cold. In flyfishing for trout or bass, the best time to fish is when the natural flies get on the water; this often depends on wind and weather; a quiet, warm morning, from $8 \mathrm{A.M}$. to 11, is generally sure sport all through the season. This time is excellent, after a night's hard rain, when the morning clears warm and quiet, on a lake; also on running streams if not in flood. At such times, many kinds of fish, usually staying on the bottom, rise to the surface. If I wanted to rest, I should choose the time from 2 P.M. till 5 . For mascalonge and pike-fishing, those hours would be my choice, or for trolling with spoon or bait, either in the early or later season, in lake-fishing. In trolling for lake trout, with spoon or minAfternoon nows, I should prefer the afternoon to any part of the day. The best part of the day for fly-fishing is a little before sundown till dark. This applies in particular to the hot days of July and August. When the rivers are very low and clear, trout and bass 


\section{When to Get Them}

are lying behind a shaded rock, in deep holes, till the setting of the sun; then all of a sudden sometimes half an hour after sunset or a little longer, when it is just getting dusk, the fish rise up in all directions, the surface of the water being a mass of fliès on the wing. Then the angler has work before him, and the advantages all in his favor; no sun to cast his shadow on the water, not too much light for the fish to distinguish the artificial nature of the flies, and the fish hungry, ready and willing to take the lure. If $I$ have no Sunset luck during the day, it's a pretty sure thing to get a full creel from sunset until dark, or when a nearly full moon is up.

If no moon is up fishing after dark is not favorable; the flies are cast without any chance of seeing the result; sometimes the leader and flies get entangled unknown to the angler, who goes on casting in ignorance of such trouble. Then the landing of a fish is much more difficult in pitch dark; better to leave off for the morrow as the fish will stay there. Bait-fishing is another matter, and can be handled with more comfort. Still-fishing for more common fishes like eels, Night perch, wall-eye pike, and catfish, is more productive of success at night than any part of the day, those mentioned being mostly nocturnal fishes. In fact, people suffering from insomnia might do worse than spend the night still-fishing on a quiet lake; the time would pass most agreeably. Taking the hook from an eel, in the dark, is a lively proposition. 


\section{Fish and Fishing}

\section{BEST SEASON}

In the regions of frost and snow there is little or no fishing during the winter, except through the ice, a practice common on the large lakes. Outside of that, the earliest fish caught is the brook trout. The date of the opening of season varies from April first to May first. Far South, in the Gulf States, fishing may be inGulf-Coast dulged in through the winter months,
Season yet the spring, March, April, and May, is the best time of the year, both on Florida and California coasts. The big game fish come in from deep water from April to June. Black sea-bass first appear in April, the tuna in May, yellow-tail in April. The tarpon first appear on the Florida coast in February and in increasing numbers in March, April, and May. In the vicinity of New York anglers go out for flounders as early as February, its bigger relative, the plaice not arriving till the middle of May. From

Opening that time on the various game fish apSeason pear along the coast in rapid succession. The striped bass follow after the shad; then the weakfish and blue-fish, so that by the middle of June, the season is well under way both in salt water and fresh. Early Fishing Next in order to the brook trout
Best comes the opening season for pike, pickerel, and pike perch, which is May 1 in New York State, May 20 in New Jersey. The 


\section{When to Get Them}

opening season in Pennsylvania is the 15th of June for pike, pickerel, mascalonge, and black bass. The same date holds good for bass in New York and New Jersey.

Certainly the best time to go for speckled trout in small mountain brooks is as soon as possible after the law permits, if the weather is favorable. The biggest fish and greatest numbers are taken early; the brooks are full of water; worms, flies, and all kinds of food are available so soon as the warm spring comes; it is then the fish are ravenous, full of life and gaminess, more so than at any later season. When the season advances food becomes so plentiful that the fish respond more tardily. In larger rivers all species of trout are later in taking the fly or bait. The open water is cold, and unless the air is warm and balmy they won't come to the surface. I have often made the mistake of fishing River Fish large, open rivers in the first of the
Later season, and got poor results, both on the worm and fly. The best indication that the fish are ready is when flies are seen fluttering on the surface. This depends entirely upon the season, a few warm days in May bring out the flies on the surface. The season $I$ consider best for trout fishing in streams forty to one hundred feet wide is from the first of May to the first of June, paying the exclusive attention to small brooks or mountain streams from the opening day to the first of May. This applies to New York, New Jersey, Pennsylvania; in more northern 


\section{Fish and Fishing}

States, Vermont, New Hampshire, Maine, and Canada, a week or two later is plenty early enough. Mountain brooks run low after May 15th, and the larger fish go down to the rivers, if not caught by that time; though a few stay in deep holes; affording chances to capture them later in the season after a flood.

Going back to the marine fishes, laws do not govern dates of capture; their arrival is soon known. Different species come in different ways; sometimes the biggest are first-comers, other times it is the reverse, though the former

Times for Sea Fishing is most usual. Bottom feeders seem to arrive ahead of surface feeders, the latter being always more numerous, and invariably in vast shoals and mostly of a given size. As the season advances the quantity grows. Weakfishing begins in June and is better in July. Bluefishing is good in July and August. Striped bass fishing is not so good early as in the fall. Fluke is best in July and August; each and all straggle on earlier or later.

For pike, pickerel, mascalonge, and bass, the early season is better than the summer, but no better than the fall; not as good as the late fall. Pike and pickerel are more ravenous early in the season, taking spoon baits readily, and are certainly less wary than during the hot months. Perch and pike perch also take the lure better early in the season. For bass-fishing there is no choice between early or late season; much depends on many conditions that are always uncer- 


\section{When to Get Them}

tain. The glorious uncertainty attending the - biting of fish is a prominent feature of salmon fishing. The runs are so much dependent on the height of water, cloudy days, and many other mysterious features, that it would be difficult to say what is the best season for salmon.

Salmon In the majority of rivers the first run is
Season composed of large females that arrive about the middle of May, very rarely taking the fly until they are well up the rivers. Most salmon anglers therefore like to be on the ground early in the hope of landing large fish. Every succeeding run is of smaller fish. The Canadian leaping salmon is, from every standpoint, best caught early in the season; from June 15th (like the trout) it is more plentiful and more gamy. In short, the best time of season is influenced mostly, if not entirely, by the plentiful supply of surface food, brought forth directly under the influence of the warm weather, after the long cold of winter. The greater part of the food of fish, such as insects, worms, caterpillars, and their like, has lain dormant throughout the cold months, to again move more actively as the sun gives its warmth; accordingly, the fish feed without stint as Weather Fishing is in a measure curtailed; food is the summer advances to hot weather. overabundant, they become satiated, feeding at night, lying still during the noonday hours. As the fall approaches, toward the advance of cold weather, they again become active in search of food, and rise to the lures with avidity. 


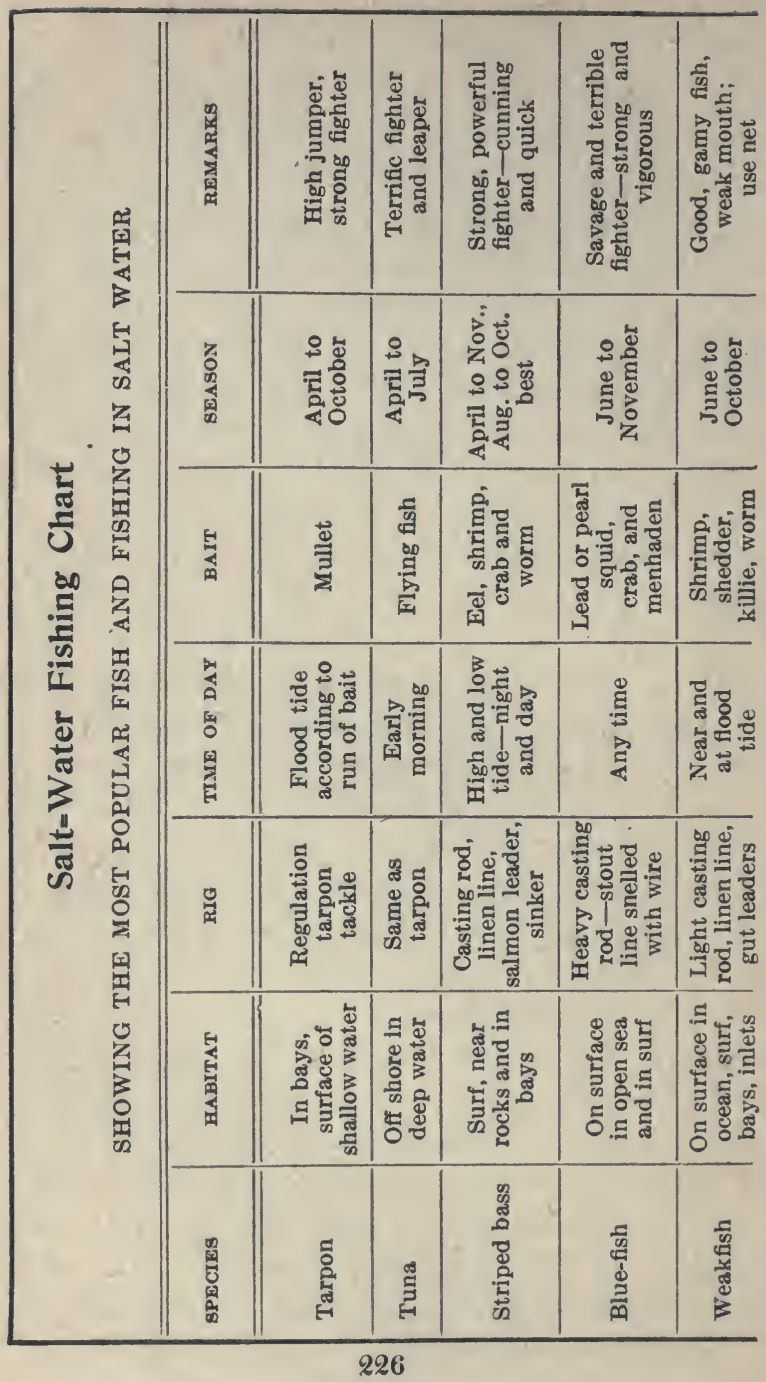




\begin{tabular}{|c|c|c|c|c|c|c|}
\hline 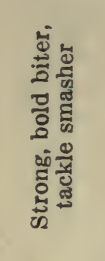 & 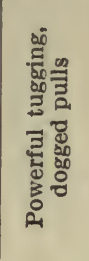 & 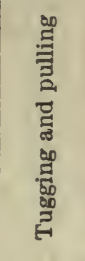 & 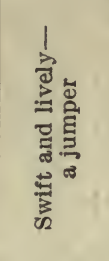 & 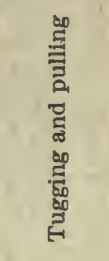 & 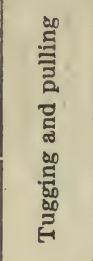 & 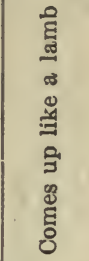 \\
\hline 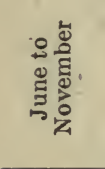 & 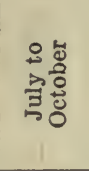 & 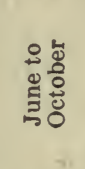 & 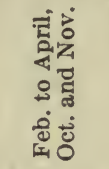 & 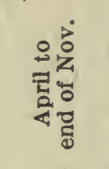 & 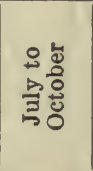 & 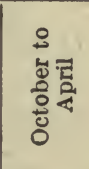 \\
\hline 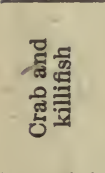 & 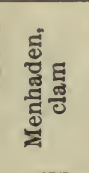 & 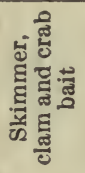 & 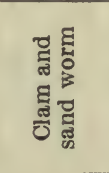 & 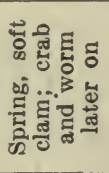 & 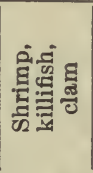 & 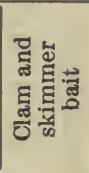 \\
\hline 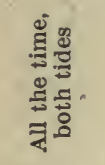 & 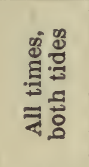 & 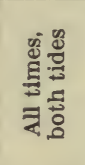 & 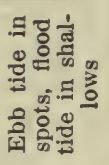 & 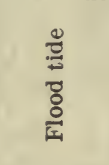 & 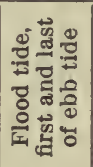 & 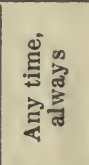 \\
\hline 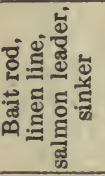 & 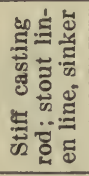 & 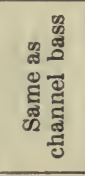 & 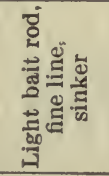 & 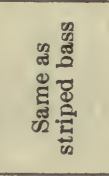 & 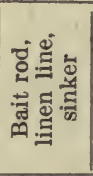 & 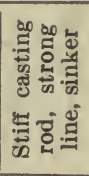 \\
\hline 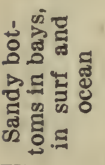 & 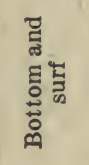 & 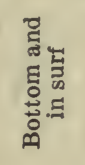 & 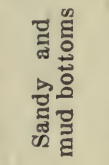 & 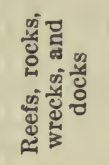 & 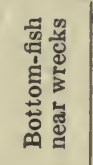 & 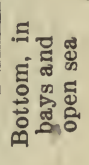 \\
\hline 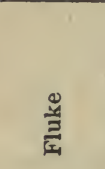 & 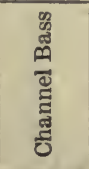 & 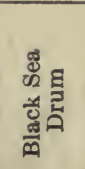 & 氙. & 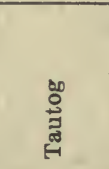 & 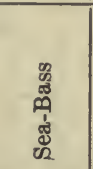 & 8 \\
\hline
\end{tabular}




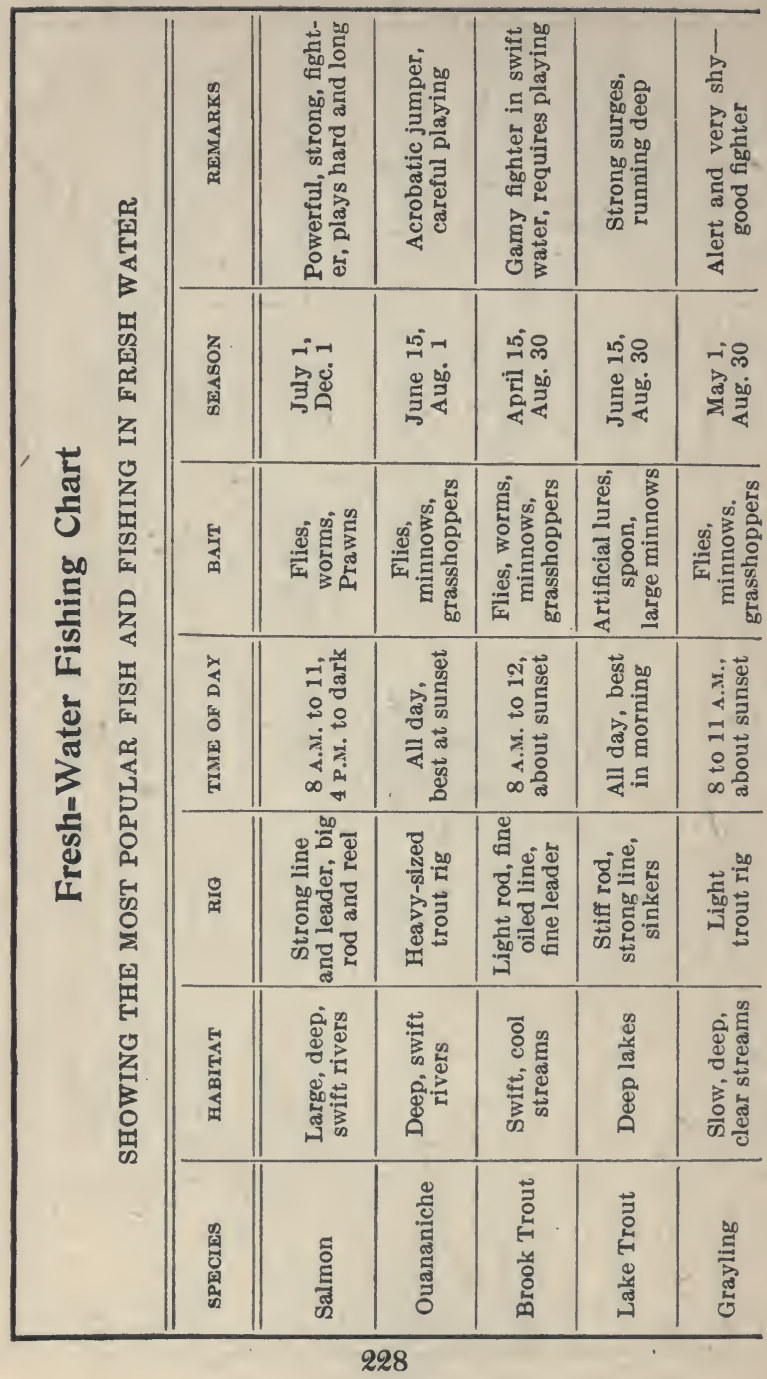




\begin{tabular}{|c|c|c|c|c|c|c|}
\hline 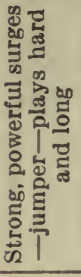 & 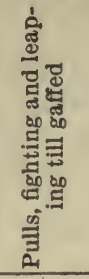 & 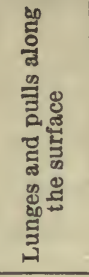 & 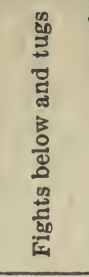 & 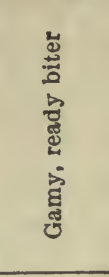 & 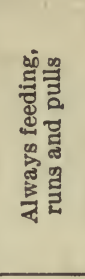 & 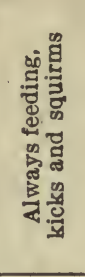 \\
\hline 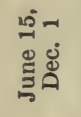 & 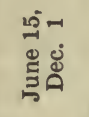 & 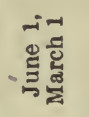 & 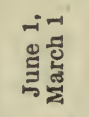 & 决总 & 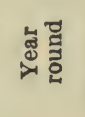 & 幽芯 \\
\hline 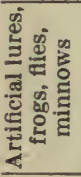 & 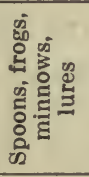 & 离兽 & 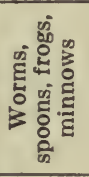 & 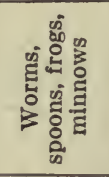 & 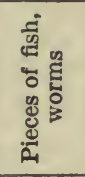 & 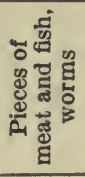 \\
\hline 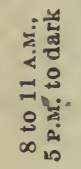 & 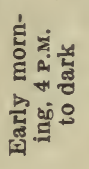 & 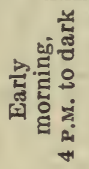 & 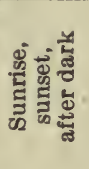 & $\begin{array}{l}\overrightarrow{\text { बु }} \\
\vec{z}\end{array}$ & 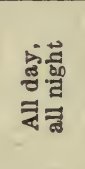 & 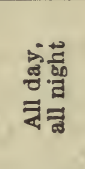 \\
\hline 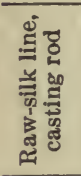 & 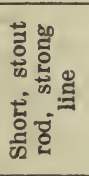 & 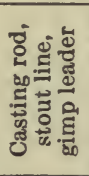 & 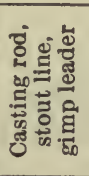 & 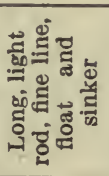 & 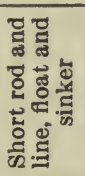 & 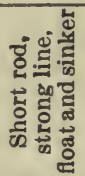 \\
\hline 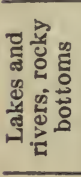 & 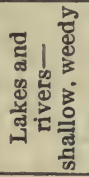 & 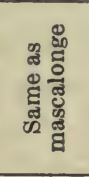 & 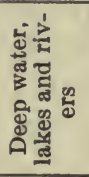 & 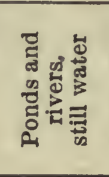 & 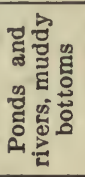 & 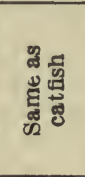 \\
\hline 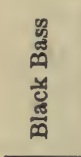 & 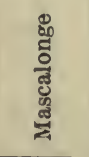 & 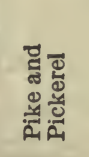 & क्ष & 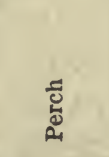 & 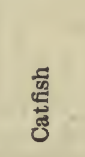 & $\begin{array}{l}\text { बే } \\
\text { | }\end{array}$ \\
\hline
\end{tabular}




\section{Fish and Fishing}

Bass are particularly ravenous in September and October; so are the pike family. Many of the trout and charr are about spawning. The season in temperate regions closes at or about the end of August. Many anglers consider October and November the best time for mascalonge, which take live or artificial minnow best

Trout Spawning

late in the season. It is difficult to say which is the most agreeable, fishing late in the fall for bass and pike, when the trees are covered with red and gold, or early in the spring, when budding out in pale green, to catch the trout or salmon with fly or worm. For my own part I like to have a fling at both.

Meanwhile deep-sea angling goes merrily on. -Weakfishing ends in October, blue-fishing in November; surf-fishing for striped bass is popular till the frost nips the fingers. The true angler is Surf Angling constant to his hobby, and patiently stays while the fish last and are found willing. It is impossible to give exactly the best time of the season for different fish, but as near as can be, a partial list would be: Salmon and trout in May, weakfish, blue-fish, pike, and pickerel in June, bass and perch in Month by July, mascalonge in August, striped
Month bass in September, pike and pickerel again in October, mascalonge again in November. December is a good month to clean and put by tackle for a short rest over Christmas, to be again on deck for a Southern trip in February to the splendid fishing grounds around the Florida coast, 


\section{When to Get Them}

till the end of March. Then the month of April could be well spent on the California coast for yellow-tail or black sea-bass, making the round of days complete by returning to temperate climates for the speckled beauties in May. Few

there are able or willing to follow out Favored the full year; others bless their stars if
Season they can get a two-weeks' trip out of the year. Each angler, I suppose, has his favorite season and favorite fish.

Some the lordly salmon praise,

And some the lusty trout,

To many men are many ways

Of fishing, without doubt.

I have tried them all, but give me the month of May, toward the end of it, just when the yellow pussy-willows are fading and the leaves a little past the bud. Dr. Henry van Dyke covers the point beautifully when he says:

Only an idle little stream

Whose amber waters softly gleam,

Where I may wade, through woodland shade, And cast the fly, and loaf, and dream.

\section{OPEN AND CLOSED SEASON}

There are abundant fishes and plenty of good fishing in American waters, notwithstanding the ever-increasing army of anglers. There are laws 


\section{Fish and Fishing}

that restrict the catch of fresh-water fish, and from a broad and general standpoint the laws are, in a way, decently obeyed. It is only the loafer and tramp who go fishing out of season. It is not the average angler who fishes out of season, nor is he a pot hunter. He wants his share, as all do. He sometimes wants to possess a little glory over his fellows by landing a bigger fish or a greater number Law Obeyed than others, and though he tries vainly to hide the secret satisfaction, it oozes out at all points and places. Fortunate indeed it is that the many game fish do not spawn at the same season; the sport is divided up into very agreeable seasons both for the nature lover and honest angler. Most fish will not bite just before and during the spawning season. The spawning fish would be captured all the same, by hook or by crook, the latter in the shape of a snare, if the law did not interfere. We have fish and plenty of them because we have laws and keep them, so far as the closed season goes.

The lesser and minor laws, such as those on netting, pollution, dynamiting, and snaring, are of little consequence unless enforced on a large scale against poisoning rivers and breeding places by large acid factories. This the State can and will reform. We will use the trout in brooks or rivers as an instance. Ninety per cent. of these waters Minor Laws have been stocked by the State. A fair estimate of the fish caught by every method, during the season, would be 80 per cent. of mature fish that are able to spawn, 


\section{When to Get Them}

the remaining 20 per cent. repopulating the depleted streams. A trout five or six inches long caught in May, and returned to the water as under legal size, if not again caught, would double its length within a year; sometimes under favorable conditions it will attain a length of fourteen inches. Such are the fish we hope to capture, and they are the direct result of the law compelling small fish to be returned to the water.

Each State makes its own laws regarding the time and length of its closed season, guided no doubt by the temperature and time of spawning, so that it is quite possible for the ardent angler to go from State to State and fish the entire yearthrough summer and fall in the North, winter and spring in the South. Up to the present time marine fishing by rod and reel is unprotected, and it is not likely that laws will be needed to restrict the catch or time of catching. So vast is the ocean and its game so immense, that the small percentage caught by man by all the Different various devices known and practised
Laws plays but a small part in Nature's adjustment of its creatures. A striking example of the reverse is apparent in the lobster and also the salmon of the Pacific, both having been slaughtered by unreasonable tincan packers, overgreedy, who soon found an end to their greed and are now propagating, or will soon have to, at their own expense. Had these same packers allowed but ten per cent. of the fish to perform their natural functions at the spawning 


\section{Fish and Fishing}

beds present conditions would be favorable to them.

Some States are more severe than others, readily recognizing the value of game fish to the State, not only in the pleasure afforded to its citizens, but in money spent by visitors. The State of Maine, in particular, would find a difference if game and fish were not abundant. Fifty thousand people would spend the summer elsewhere. It is only a closed season on fish Value of Closed Season and game that produces the supply demanded. The great railroads are now taking considerable interest in fish and game sections along their lines, issuing elaborate booklets on the subject purposely to attract wielders of the rod and gun to spend vacations in districts well supplied with game. Such places cannot be maintained without a closed season to replenish the ravages made in various ways.

The State of New Jersey has a minor law forbidding certain fishes to be taken at night. To be exact: "Fishing between 9 P.M. and daylight is prohibited for trout, bass, pike, pickerel and pike perch." This law may not be kept, but its moral effect is good. Decent people will not intention- ally break the law. Anglers as a body, that is, ninety-nine out of one hundred, will consider the law principally made for their special Fight benefit, and I find they usually act upon it. This night law is aimed at wormfishing for trout and by set lines in minnow fishing for bass and pike; both are deadly modes, for 


\section{When to Get Them}

many fish are caught after dark by these methods. This night law should be copied by many other States. At the same time comparatively few practise night-fishing, but those who do land many fish and big ones too. Such a law would stop it.

The trout season in New York, New Jersey, and Pennsylvania, from April 15th to August 31st, and in many of the other States, in the temperate zone, could be, with advantage, curtailed a month, the date being changed to the last of July. The bulk of the trout are caught by the end of June; few fish are caught in July or August, except those caught at the bottom of large lakes. But the law could be made to cover rapid streams and mountain brooks, which are often dried up in the month of August.

The opening season, especially in mountainous regions, is too early. The first day of May would be better for the fish and for the angler. On the 15th day of April the streams are so cold that fishing is a waste of time and energy. The perfect time for trout-fishing, in the above mentioned States, is from May 15th to June 15th, or from Open Date too Early May 1st, if the season is mild. The opening day on Long Island is April 1st, made so because the land lies low, the water being very free from ice and the air milder, at least two weeks, ahead of the highlands. The 1st of April this year, was a warm day. I saw four varieties of natural flies on the water, and the trout took my artificial flies in splendid style. 


\section{Fish and Fishing}

In nearly all instances fish refuse to bite during spawning season in the ocean. Similar conditions are no doubt the same in fresh-water game fish. In trout-fishing, during the spring, I never hook a bass occupying the same water, but I get quite a few bass on trout rig after the season opens on June 16th; on the St. Lawrence the date is June 10th, on Lake George and Schroon Lake, as late as August 1st. These varying dates are due to the difference in the temperature of the water and lateness in spawning.

The closed season is not so much for the angler as the net fishermen who make a business of selling fish. Many of these are highly respectable men who are as anxious as anybody

Net

Fishermen to see the law obeyed; others of a different mould, like the shad fishermen on the Hudson, when they net a salmon in the shad nets, prefer to keep it instead of returning it to the water, as the law requires.

\section{BEST KIND OF WEATHER}

The weather has a most important bearing in the catching of fish. The most disagreeable are windy days. A perfect day for fishing may be described as a warm, pleasant day, with a balmy, Perfect Days invigorating breeze, a mellow sunlight, not too bright, produced by a somewhat hazy atmosphere, or by drifting clouds, when the season has been neither too wet nor too dry. The worst day for fishing is either 


\section{When to Get Them}

a cold north or east wind, especially when against the direction you are casting the flies on a running stream; or, again, the same wind blowing hard across a lake is equally disagreeable for trollWindy Days ing or still-fishing. A good windy from the south, rippling up the water in little wavelets, destroying the placid, even surface and hiding the angler from the fish. It is then, if the weather be warm, that trout, bass, perch, and even pike perch, may be coaxed up to take the fly; it is favorable for trolling with bait or spoon, either for pike or mascalonge. Rippling water seems to have the effect of hiding the line, as it also helps to deceive the fish as to the nature of the artificial fly.

After a hot spell when fish have not been biting, a shower or a good smart rain of a few hours will have an immediate effect for the good of the angler. The fish will not only rise better to the fly, but will also take the worm. The reason is obvious. After a clearing up, flies may be seen all over the water, and rising fish popping in all directions; if the water has not become muddy, Wet Days numerous worms, caterpillars and insects are washed down, placing food before them in plenty, and a wriggling worm, deftly hiding the hook, never fails to be taken with a rush. After a freshet, when the water clears sufficiently for trout to see worms or flies, the angler will find his creel rapidly filling up. High water is always a better condition than low water, no matter what time of day or season. I consider 


\section{Fish and Fishing}

water just cleared and going down after a freshet the best either for fly-fishing or bait, and I think this applies to nearly all fish, in brooks, rivers, or lakes. In brooks, swollen by rain, the fish have a wider field to forage, with a chance to dart across when they see a lure; and in rivers they move from their favorite haunt, prospecting and going in search of anything that is washed above them. In lakes they rise to the surface to feel lower temperature, which a plentiful supply of rain gives to the surface, and so take the bait if offered. Calm, hot, and dry weather make Dry Days the worst conditions for the angler to contend with, because the river gets so low and water so warm that the fish refuse to leave cool, sheltered holes, where they hide from the hot sun's rays. I was fishing this season on a stream, using the finest flies and gut without success. In wading down the shady side near the shore, I constantly saw nice, large fish dart from under large bowlders; and even from the very edge of the grassy borders of the stream they would rush off suddenly toward the middle. Possibly they were taking an afternoon nap or rest, for surely they were not taking any flies. I fished the same stretch after sunset and soon filled my basket with good-sized trout. They were simply not feeding. The warm sunshine was too hot for them; no flies were on the water, so they would not take mine.

Both trout and bass are rarely inclined to go for any lure if they see the angler, and on warm, sunny days it is most difficult to get the lure near enough 238 


\section{When to Get Them}

without either the rod or line, maybe the angler himself, being seen. Low water on such a day

Hot and Clear Days

proves very thoroughly who is the expert or the duffer. Either it has to be the fly cast far and fine, or the worm worked with such art as few anglers are capable of.

If a worm is taken under such conditions it must be so that the piercing eye of the trout cannot see either hook, leader, line, or rod, and certainly not the angler. Above all, the worm must kick just like a natural worm floating down the stream. 


\section{CHAPTER VIII}

\section{With What to Get Them}

\section{RODS}

In the art of rod-making the manufacturers have produced the most perfect implements of the craft. The skill and ingenuity employed in this industry within the last few years shows that for all kinds of angling a perfect rod is available, so that few, if any, spend their time in making their own. The essential qualities of a fine rod are balance, lightness, pliancy, and strength.

The time has gone by when the angler is contented to use one rod for all kinds of fishing. Each fish requires its own peculiar length of rod, weight, and strength, and each method of fly-casting, casting bait-casting, and trolling makes it necesPower sary that the rod be suited to the style of work required. A first-class split bamboo of perfect action is, to my mind, the best in casting power for fly-fishing, either for trout or bass; though the bamboo is such a popular favorite here in America, it is not in such general use in Great Britain; and there, as well 


\section{With What to Get Them}

as in America, salmon rods are nearly all of greenheart. Most salmon fishermen consider the bamboo rods light and delightful implements to handle, but many have found them subject to a kind of dry-rot near the joints, which develops generally after one or two seasons' use, when they will sometimes break at an ordinary cast, without the least previous sign of weakness.

The proper bait-casting rod for bass, trout, pike, pickerel, wall-eye, or any fish of a like weight, in fresh water, should be strong, yet light Bait Rod weight; that is, six to eight ounces, and in length eight feet, more or less, according to taste. It should have a stiffish back, but pliable to respond to the varying moods of the fish. Most of the bend and play should be in the upper two-thirds of the rod, making a true arch. The most serviceable material is an ash butt and lance-wood second piece, and tip of the same.

The perfect rod for fly-fishing (dry or wet) for trout, is also suited to bass, ouananiche, grayling, perch and other smaller fresh-water fish. It should be rather stiff and powerful, made either of split bamboo or greenheart. The majority of anglers use a rod varying in length from nine to eleven feet. Above all things, let the length of the rod depend upon your own strength. The actual weight of the rod is not of the first importance; in Fly Rod fact, by adding weight to the butt they at once feel lighter, being thereby better balanced. I have often met anglers using a rod in fly-casting weighing but four or five ounces. 


\section{Fish and Fishing}

This lightness may be easier and less tiring; but a good, far cast is impossible, and a largesized fish has considerably more power over the angler. These weak, whippy things are only fit to play fingerlings on. A good-sized, strong bass or ouananiche requires a powerfully built rod. A short, very light rod is of value for close, accurate casting with a fine line and small flies; it is almost useless for dry fly-fishing, as without a certain amount of weight toward the top the fly cannot be picked off the water.

In the last few years the salmon rod has been modified considerably, both in length and weight. A rod for use from the bank should be longer than one used from a boat or canoe, as in the latter method the canoe can almost always be placed within an easy cast of the spot one wishes to reach; whereas, in fishing from the bank it is frequently necessary to make casts beyond the scope of a short rod. Few would now use a rod longer than eighteen feet; whereas, twenty-five years ago rods of twenty to twenty-four feet were in common use. The average size salmon rod for general use is from thirteen to sixteen feet long, with a weight of about twenty-five ounces. The combination to be sought in a rod, and not easy to find, is one of strength, lightness, and casting power that is adaptable to a short as well as to a long line. Salmon Rods

There are many rods which need a heavy weight of line to work well, and at any distance under fifteen to twenty yards they are too stiff for good work; others are so limber 


\section{With What to Get Them}

and springy that they are only capable of doing well at short ranges, and are useless for anything like a long cast. A properly constructed salmon rod should have the strength equally distributed from butt to tip, so that a pull at the latter point will cause the rod to bend throughout its entire length. If the spring is confined to one-half the length, owing to weakness of the tip or stiffness of the butt, the rod is defective; for in casting, the spring should be easily perceptible to the end of the butt; such a rod can be used for lake trolling or spinning for salmon if a shorter tip is used.

The modern, up-to-date marine rod can be procured in every style, weight, or size. It can be made of one long tip with short butt, when jointed, measuring five and one-half feet and weighing but five ounces, up to the powerful tuna rod of seven feet and weight of twenty-five ounces. The angler can choose excellent rods of steel, split bamboo, greenheart, lance-wood, noib-wood or bethabera, all being priced according to the finish and trimmings. Anglers' opinions are so varied as to what is really the best, that it is quite possible there is little difference in the matter, when the best of each is considered. Of the solid

Different Woods woods, a rod made of noib-wood has a large number of admirers because of its great toughness and elasticity. It is grown in the tropics and imported by a tackle dealer specially for the purpose of rod-making. It is admirable for salt-water fishing because it is harder than either greenheart or lance wood, and 243 


\section{Fish and Fishing}

will bear any amount of hard, rough usage. These rods are made with rubber detachable butt and patent adjustable locking reel band, with double bell guides and agate tips. Tips of various weight may be used with the same butt, either for light weakfishing or heavy tuna or tarpon.

The best hand-made hexagonal split bamboo rods are certainly powerful, yet springy. They are made in the same varieties of weights and lengths, from six feet to seven and one-half feet. The bamboo is a general favorite and is probably more popular than any other kind; it is lighter, and if taken care of will wear for many years. Bamboo From the nature of its construction, it as a rod of solid wood. Dampness and excessive heat are the greatest enemies of bamboo. It is very rare that a fish, if properly played, will break it, no matter what size the fish is.

Of the steel rods now for sale, I can safely say they compare well in every particular with the best of the solid woods or bamboo. They are Steel Rods particularly good for salt water which is so trying on bamboo because both the salt air and water soon play havoc if due care is not used; but with a steel rod our mind is at rest. They are made, like the solid woods, to suit every kind of fishing.

The salt-water rod, made for tarpon and surffishing, is powerfully built, two-piece and butt, six feet nine inches long, weight twenty-six ounces, 


\section{With What to Get Them}

German silver mounted, agate guides, and is about half the price of a first-class all-wood rod. If the angler has special fads, requiring special finish or different wants, he has only to express his desire and they are supplied. The steel rod has many extra advantages. One is the telescopic bait and fly rod, with the line running through the centre of the rod. This seems to be the perfection of comfort in fishing, if it works right, and though I have not used this particular one, there is no doubt it is a useful rod. Everything in rods is available in steel. One of the latest is a combination reel and handle, whereby the line runs directly up the centre of the rod, being well balanced and natural. This idea, it seems to me, ought to be used in big game fishing, both for marine and fresh water, when reels are so liable to be disjointed, and have to be lashed on secure in addition to the usual seat rings.

I have used the steel fly rod and like it. It is heavy, compared with the four-ounce rods, but as previously remarked, I don't fish for fingerlings; I want to cast good distances, and have confidence in the mastery of large fish which cannot be got out of a peacock's feather, and can be got out of a steel rod. Indeed, I hate to treat my bamboo harshly-not that it won't stand it, but I don't care to try.

In fishing for mascalonge, I am more aggressive, because the antagonist is (if large) my equal, indeed, my superior in cunning, sometimes in strength. Now a steel rod is hard and cold; one 


\section{Fish and Fishing}

feels with a thirteen-ounce mascalonge rod, made of steel, no qualms of conscience that the fish will be lost; so we hold the rod upright, even if the boat is being towed.

\section{REELS}

It can hardly be doubted that the American reel as perfected at the present time is in every way everything that the angler could desire, so that few, if any, demand imported reels, as they do flies, gut, lines, and rods. Not only are the reels, as now made, well made, but they are ingenious to a degree, and every season we find some new device or attachment that is really worth while. A reliable, good reel contributes much to the pleasure of angling, especially now that the monster game marine fish are caught in true sportsman-like fashion.

There are three kinds of reels employed in angling: the click reel, used by and so important to Variety of the fly-fisher, the multiplying reel, so Reels

necessary to the bait fishermen, and the automatic reel, so useful when angling for gamy fish that run back and forth too quickly for the angler to retrieve in time. There are the "single action," "double multiplying," and "quadruple multiplying" reels; there is also what is known as a "cone-bearing" or "compensating" reel, whereby the "cone screw" is tightened to keep the spool from wabbling; and a number of "take-a-part" reels, all 


\section{With What to Get Them}

made so they can be cleaned and oiled and put together again by loosening a screw. Since the advent of big-game fishing a new device to aid the angler is called the "drag," which creates friction enough to prevent the fish from taking the line too fast, in place of the thumb or the "thumb drag" made of leather. Saltwater fishermen, in deep water or from piers, and at a distance from the water, use a large wooden reel, five to seven inches in diameter; for surf-fishing, a nickel-plated double multiplying reel, holding from 100 to 400 yards of line, made with extra-heavy gears and click.

For tarpon and tuna fishing, large powerful reels are made specially designed to meet the terrific strain of a tuna rush, having a capacity Marine Reels of 300 yards of No. 24 Cuttyhunk line. They are mighty engines and, when attached to the rod in use, seem powerful enough to land any living moving creature of any size in the water.

Since bait-casting has become one of the fine arts of angling, it is, of course, essential that a reel must not only be very rapid, but run with the greatest freedom and ease, so as to deliver the bait as far as possible at a single cast, the thumb, meanwhile, controlling the rapid rendering of the line, and preventing back lashing of the spool. The main object of the multiplying reel, is for facility in casting, not in retrieving the line.

On the other hand, the click reel is much better for the purpose of casting the fly. The line is 


\section{Fish and Fishing}

lengthened gradually, a few feet being taken from the reel by the hand, before each cast, while the Click Reels click offers the necessary resistance to the rendering of the line and prevents overrunning. Furthermore, in playing and landing a fish, a click reel is much better when the spool is rapidly revolving under the rush of an active fish; the click acts as a gentle retard or break.

In fly-fishing, my line is very fine, as is also the leader, so that I use a very small reel, part rubber and aluminum. I am not an advocate of highly polished metal in any part of the tackle, except as a bait. I have had numberless proofs that shining metal on the reel and on the rod are a means of drawing the attention of shy fish to the angler. For that reason choose a black or phosphorbronze reel.

Regarding the automatic reel, as yet I have not used it, though many friends tell me if $I$ once take it up I shall not in a hurry want to discard it. There are a number on the market, Automatic made for bass, trout, and salmon.
Reels

One of the first and best automatic reels made was the Orvis reel, invented by Charles F. Orvis, of Manchester, Vt. It has a long, narrow barrel, enabling a fish that "runs in" to be wound up so fast that the evils of a "slack line" need seldom be felt. Besides lightness, the perforations of the side plates allow the air to get to the line, which prevents the latter from rotting if left damp. A later device, but 


\section{With What to Get Them}

somewhat similar, is a combination automatic, which may be made either automatic or freerunning by the pressing of a catch; it is wound up by a key. The Martin automatic is another, similar in shape to the Orvis, but has, in addition, a lock brake to hold back the tension lever while playing the fish.

The "Old Virginia" automatic is a reel that may be changed instantly from an automatic selfwinding reel to one which embodies the good qualities of a multiplying, or a single-action reel. The operations of the reel are changed from automatic to single action by pushing in the handle one-eighth of an inch. The mechanism and speed are controlled without releasing hold of the handle. The spring may be wound up by drawing off the line or by turning the handle as if to wind in the line. Of course, in case of a kink in the line the automatic must be a perfect terror, especially when wading the middle of a stream.

\section{LINES}

For the variety and number of game fish treated in this book it is impossible to do justice to the numberless different lines, dressed and undressed, silk, linen, and what not, for fresh water and for salt water, which compete for the angler's favor.

For fly-fishing gencrally-by that I mean for salmon, trout, and bass - the best line is the tapered and enamelled water-proof braided silk; there are many different makes, but for smoothness, 


\section{Fish and Fishing}

roundness, and polish, I know none better than the "Kingfisher" lines, made by Martin \& Sons.

Fly=Fishing They are sold in twenty-five-yard Lines

coils. Four coils, or more, are connected. They are beautifully polished, to slide through the water, and are perfectly water-proof, some being single-tapered, others double-tapered, in various sizes and lengths. They are made in various colors, but I prefer the light olive green which harmonizes well with the tints of the water, sky, and foliage.

In salmon fishing the enamelled silk line is sometimes spliced to a double length of linen Cuttyhunk, the first part being fifty yards and the latter one hundred yards. In winding a new line on the reel the greatest care should be taken to wind it without kinking before being wet, otherwise it is apt to fold or loop over; but after a few wettings the stiffness will disappear, and it will also cast much better.

In bait-casting the best line is that of raw silk, closely braided, and if hard it will absorb little water, and is therefore light and elastic. Raw-silk braided lines need the greatest care Bait=Casting to preserve their usefulness. They
Lines should be carefully dried after use, as soon thereafter as possible, to prevent them becoming weak and rotten. Next to the raw silk is the braided boiled-silk line. If not closely braided they absorb water quite freely, and so cling to the rod, interfering with the free rendering of the line. The braided linen can be 


\section{With What to Get Them}

used in trolling for bass and pickerel, but for pike and mascalonge nothing equals a medium-sized Cuttyhunk line which is of a dark green color.

For all-round marine fishing the "Cuttyhunk" and a good hand-laid Irish linen are by far the best and strongest. Of the latter, a No. 12 will take a fish up to twenty pounds weight, No. 15 will take a fish up to thirty pounds, No. 18 up to one hundred pounds, and the last can be used for tarpon. No. 21 is strong enough to use for the tuna and black sea-bass. No. 24 Salt=Water is suited to fish that require heavy
Lines lifting, as the jewfish, leaping sharks, and others. The linen lines should always be soaked and stretched for a day previous to use, and allowed to dry in this way. This sets the lay of the line, and not only lessens the liability of kinking, but helps to even its strength.

In tuna and tarpon fishing at least 800 feet of line should be on the reel when the fish is "going;" the leather brake should never be used upon the line unless it is wet, as the friction will burn the line. The "Joseph Jefferson" tarred tuna line is the best for heavy fishing.

For smaller fish up to eight pounds, there are numberless braided and twisted linen lines, sold in coils or in hanks. Every one can, without difficulty, suit his particular objects and tastes.

All fishing lines that are not Care of Them absolutely water-proof should be carefully dried after use; and even water-proof lines would be much benefited by an airing be251 


\section{Fish and Fishing}

fore putting them away. Even the best lines become weak and worthless through a want of proper and judicious treatment.

\section{GUT}

The material of which leaders and snells are composed is produced in Spain and Italy. It is the fluid silk, drawn out into various lengths, from the silk-worm. When the worm is about to spin its cocoon it is killed by being immersed in vinegar which perhaps has also some effect on the viscid fluid in the sacs. These sacs are then stretched, the fluid being drawn out until the proper length is obtained, when the two ends are What is Gut? wound around pins driven into a frame. Afterward the adhering skin is stripped off, leaving the gut fibre white and glistening. It is then sorted according to thickness and quality and tied in bunches. This, then, is what is known as gut. The silk-worm gut imported into the United States, and used for leaders and snells, is in short lengths of from twelve to fifteen inches. In forming leaders these are knotted together to the desired length. There are many grades of gut, and to buy the best is the cheapest. I do not advise buying Buy the strands to make leaders. It is Ready=Made far better and cheaper to get leaders
Leaders ready made. The best salmon leaders are from six to nine feet'long and cost from sixty cents up. They are furnished with and 


\section{With What to Get Them}

without loops. The best leaders are composed of the longest, the roundest, most transparent strands, sixteen to eighteen inches long.

A good salmon leader, with proper care, will last some seasons, and because of its thickness requires to be well soaked before casting. This applies to all leaders, in fly-casting, from the very finest trout leader to the heavy salmon. While very few anglers tie their own casting lines it is desirable for all to know how a broken leader can be mended, how to make a proper knot for the loop at the end, and how to fasten a casting line which has no loop at the end to the loop or eye of the hook.

Abbey \& Imbrie supply a mist-colored leader of the best quality for trout; it is perfectly even, strong, yet very fine. I consider this the finest leader obtainable and the most satisFine Trout factory for fish not over three pounds,
Leaders either speckled, brown, or rainbow trout; that is, for fly-casting on running streams with very small flies. For lake-fishing or deepwater trolling, that known as "heavy trout" is none too thick for the purpose. I have taken bass, nearly three pounds, on the "extra light" leader and small flies in running streams. For the large fish of Maine and the lakes in the Adirondacks as well as in Canada, light salmon or bass leaders are none too light. For the heaviest fish I do not advise double leaders. The heaviest salmon leader is quite strong enough to land any fish, unless of unusual size. Most of the leaders are 


\section{Fish and Fishing}

made in three-foot lengths. They can be attached to any length desired, but to my mind a nine-foot gut cast is too long, as it is more difficult to bring the fish to the net with a very long leader, if it cannot be drawn through the ring tip. In salmon fishing the case is different because the rod is of sufficient length to handle a nine-foot leader. In fishing for the ouananiche I use a salmon leader, with dropper loop. A trout leader, even a heavy one, would not hold a minute against the kicks of that lively fish in such turbulent waters as those of the Grande Décharge. The use of double and treble gut is only desirable for snells and leaders in salt-water angling, and should not be used for any fresh-water game fish, unless in very deepwater fishing where the light is poor.

For trout-fishing, the very light leaders can be cast much more softly on the water, and the line will force a light leader much more readily than a coarse, thick one. The same holds good in flyfishing for bass. It is most essenFly and Snell tial that the fly snells be of the of Uniform Thickness same thickness as the leader; a thick snell on a fine leader hangs down, and does not work away from the leader; the same difficulty is apparent if a thin snell is attached to a thick leader, because it always wraps around and gets entangled in the leader.

"It may not be amiss to state that in dry fly-fishing only one fly is used at the end of a six or ninefoot leader. In trout-fishing some use two flies with the snell of the dropper or second fly not 


\section{With What to Get Them}

more than four inches long. I always use three flies, on a six-foot leader; some British anglers use four and even six flies on a nine-foot leader. In salmon fishing, both sea and landlocked, sometimes only one fly is used, and some use two. In bass-fishing the same, but the snells should be five or six inches long on salmon leaders which are invariably nine feet in length. For bass-fishing with a fly, I have always used trout flies and tackle, and with them I have caught not a few; but other anglers prefer to use only two flies, and some only one.

\section{HOOKS}

Many writers expend their indignation against the makers when they see the fierce array of treble and gang hooks. On this subject I have nothing to say, except that I believe the matter will adjust itself. Those anglers who think it not humane will take off the gangs and use single hooks; others will think nothing about it, but will continue to use tackle that is sure to hold, with the idea that they go fishing to hold the quarry, not to lose it. The makers are there to sell what is demanded; when a change is desired they will supply it. Few anglers worry their brains about the bend, size, name, or strength of hooks; the majority just purchase what the dealer recommends. Yet the thoughtful angler will delve into the "why and wherefore" of hooks, intelligently to discriminate that which is best and most serviceable, because it is rare that shop salesmen can answer 


\section{Fish and Fishing}

with any degree of knowledge many of the questions put to them.

Within the last few years, and, indeed, at the present time, hook-making is in a transition state, especially in the manner of eyed hooks, not only for fly-fishing but bait-fishing. I think the day is Eyed not far distant when all hooks will Eyed Hooks be "eyed," for both large and small game, and the old fashion of lashing the gut to the shank with waxed silk will be done away with.
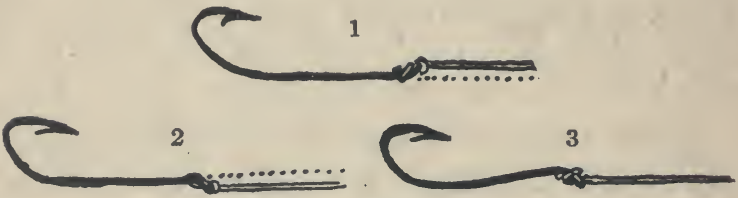

Showing gradual improvement in correct draft line of eyed hooks.

Eyed hooks will come into practical and general use among anglers.

In both salmon and trout fishing the matter of eyed hooks on flies is perhaps of much greater importance than on any other hooks used in fishing, as it interferes with or benefits the proper working of the fly. Naturally, because fishing is an older science with them, the eyed hook is an English invention. From the first, Hall's "new eyed hook" or "turned-up eyed hook" was used for dry floating flies; soon after came a decided improvement in the Pennell turned-down eyed hook, with a still further advance in excellence in the new patent, the up-turned shank and turned-down eyed hook. 


\section{With What to Get Them}

The cut shown opposite gives a fair idea how the draft line has been perfected.

Not only in fly-fishing, but in big game fishing for tarpon and tuna, as well as for codfish, sheepshead, black-fish and bass the eyed hook is commonly used. Its convenience is that any attachment, either snell or line, can readily be fastened. If the eye is properly made it holds more weight than any other form.

There seems to be no limit to the number of

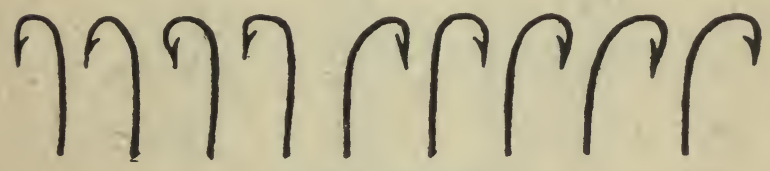

Popular hook bends.

shapes and bends of hooks, and the most popular all-round hook, for large-size fish, seems to be the sproat or O'Shaughnessy. Between Shape or the two there is little difference; both
Bend are strong and powerful in shape the sproat being what may be termed a central draught hook, that is, the direction of the point of the hook is toward the end of the shank. In tarpon and tuna fishing, the Van Vleck shaped hook is more in common use. It is a deep, wide hook, with short shank; its appearance gives evidence of great holding power. Most of the shanks are eyed or ringed to the various snells by means of a large swivel to connect the line. There are three snells used for tarpon, one a four-inch solid linked chain, attached to the 


\section{Fish and Fishing}

hook by a ring, fastened to a four and one-halffoot piano wire; the second style is a thirty-inch phosphor-bronze cable, with end swivels; the third is a thirty-six-inch, hand-plaited, linen snell, wound with copper wire.

For smaller game the favorite hooks now mostly used in the United States are the sproat, Carlisle,
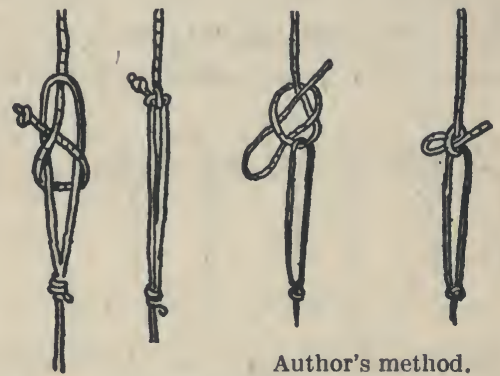

Author's method.

Reel-line and casting-line attachments.

O'Shaughnessy, Aberdeen, Dublin Bend, and Hollow Point Limerick, and the new pattern Names of Pennell Limerick hooks. With regard to the best bend of hooks opinions are so wide and varied that it would be wearisome to the angler to describe them. Some like the points bent slightly sideways, claiming that it helps the point of the hook to catch in the fish's mouth. Another considers the side bend the worst possible crook given to a fish hook, being both unscientific and impracticable. Personally, I like a slight bend in fly hooks, as well as bait hooks, especially for minnows or worms. The live bait, to my 


\section{With What to Get Them}

mind, holds on the hook better and I think holds the fish more securely.

There is no question that if the angler persists in getting the highest grades of the best makers,

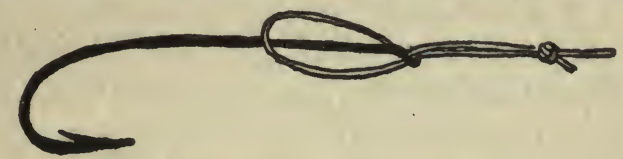

Single slipknot attachment.

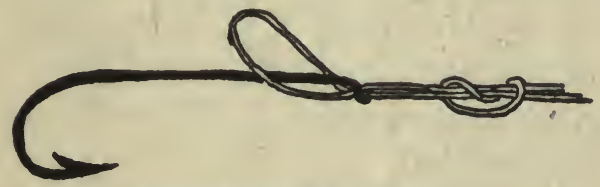

Double slipknot attachment.

mostly English, he would be on the right track. Anglers soon find out what they like most in style of bend, of shank, barb and point, all of which are of the greatest importance. Some hooks are made

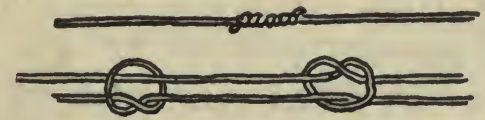

Single fisherman's knot or buffer knot.

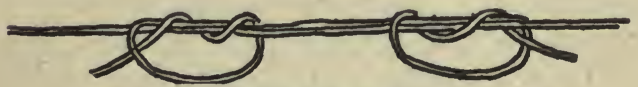

Double fisherman's knot.

for general service, others formed for particular kinds of fish or special methods of angling.

In using eyed hooks every fly fisherman should understand how to tie a strong, neat, and durable 


\section{Fish and Fishing}

knot, to join together broken gut, to make a proper attachment of drop fly to casting line, and to connect the casting gut to reel line. Various For the latter I have never known the method that I use to fail, and it is the easiest to do, and undo, being simply a common bow knot tied to the loop, commonly called tiller-hitch or helm-knot. Before tying, gut should always be well soaked in tepid water, as it frays and cracks if dry. Decidedly the best, as well

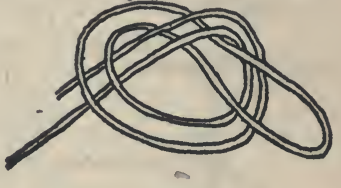

Knot for gut-loop. as the simplest knot, and one that is equally applicable to the finest as well as the strongest gut, is what is known as the single and double fisherman's knot. Then there is

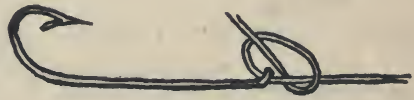

Half-hitch jam knot.

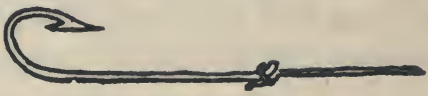

Completed. the buffer knot for salmon gut, the half-hitch jam knot and a single and double slipknot attachment to eyed hooks. The tyro can study the plates on knots, then by practising them can learn to tie each readily and properly. Sometimes the eyes are not of the same size; if too large for the gut the fly is liable to slip down out of place. In other words, it does not firmly stand out from the gut; in that case it should be tied double. If the eye is too small for the gut to go through, then 260 


\section{With What to Get Them}

smaller gut can be used. The main point is to have the knot neat and so easily made that it can be undone without using a knife to cut the gut, which soon becomes too short for service if cut often. Many of the trout and bass leaders are now made with loops, generally three loops, so

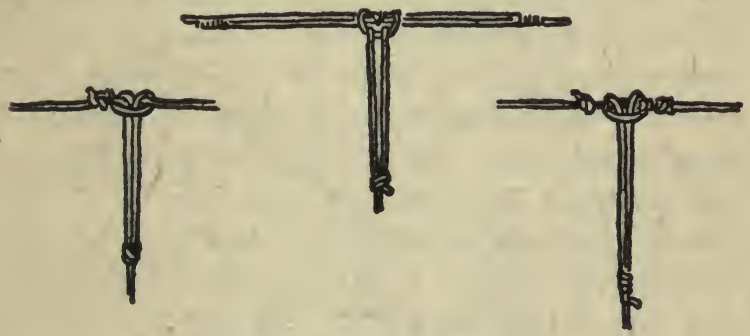

Salmon drop-fly attachment.

that if eyed hooks are used the snell has simply a loop tied at one end, leaving the other end to be affixed to the hook by a jam knot, the length of the snell being not over three inches. Short snells and droppers stand out much better from the leader.

\section{EQUIPMENT}

DRESS

To some "half the fun" of fishing is to get soaking wet, but they are mostly in the period of "wild youth"; in after years, and having become veterans, they would give something considerable to have omitted such fun. Getting soaked and re- 


\section{Fish and Fishing}

maining so engenders many of the after ills that flesh is heir to, in the shape of rheumatism, neuralgia, varicose veins, and the rest of them. Don't make a practice of going into cold spring water at all seasons' of the year. In warm weather a pair of brogans and a suit of old woollen thin clothes are best. For the months of April, May - even June and September-October and November especially, keep your toes warm. Of wading trousers, shoes, and hip boots there are legion. Those imported from England are excellent material and make, but so clumsy, heavy, and tedious to put on and off as to be a perfect burden. To put on a pair of "life-belt wading trousers" a reasonably fat man has to have two or three assistants, and to take them off use a derrick. Mackintosh trousers with rubber feet are tolerably good wading boots, having heavy Various rubber soles and canvas uppers; they have
Clothes good qualities, as have leather brogans over wading trousers. All these, however, require much care, to dry and keep in order and keep pliable. To my mind, nothing is so good for wading streams in fly-fishing as a pair of "Goodyear hip boots" and a folding rubber cap with cape, covering the shoulders, these to be worn over the above-mentioned old suit of gray woollen thin cloth; the rubber cape is only used when it rains, otherwise it can be kept in a snug corner of the creel. In ordinary weather, the neat, small, closefitting peak cap, over which the rubber cap will snugly cover, can be worn. The streams I wade 


\section{With What to Get Them}

are very strong and slippery and to obviate constant "duckings" I wear a pair of leather sandals, made of thin, pliable leather, easily buckled; the

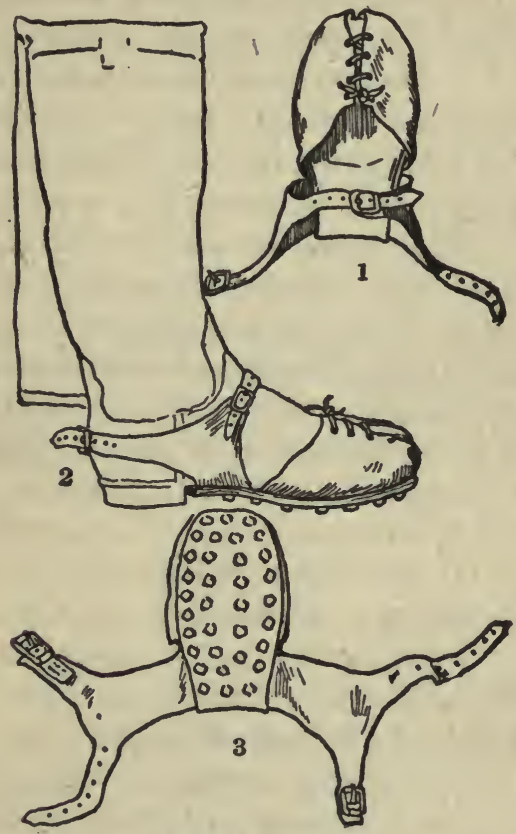

Author's sandal.

1. Upper view, ready to slip on. 2. As worn over rubber hip boots, simply buckles at the back. 3. Lower view, showing shape of upper leather unbuckled.

sandal having a stout but not thick sole, studded with hobnails. In walking any great distance, out of water I slip them off and place them in the creel till again required. These sandals serve a number of purposes; they prevent slipping, give 


\section{Fish and Fishing}

a solid grip to the feet, and prolong the life of the rubber boots to two and three seasons' hard usage; without the sandals they would wear out in a seaHip Boots and Sandals

son. The sandals I now wear I have used eight years, and they are good for as many more, with new nails and slight mending now and then at small cost. These sandals are not on the market, being made by a harness-maker, living near the Beaverkill River, and are in use by many of the anglers on that river. Any cobbler of average intelligence could make a pair from the cut here given. I have found them the greatest comfort of any part of my angling outfit. They cost to make two dollars, but are worth their weight in gold. Inside the rubbers I wear hand-knitted socks of gray, "all wool"; they are a blessing, absorb the moisture if the feet are wet, as sometimes one punches a hole in the rubbers, and keep the feet warm. For early spring, when the Woollen weather is chilly, I put on a woollen
Socks sweater to keep the chest warm and the cold from my throat and neck; when it is worn the waistcoat can be discarded. The advantages of the outfit are that it is light, not bulky to pack; indeed, it can all be packed in a dress-suit case for a two weeks' trip. The fishing suit should not be too disreputable to wear at table and about the hotel; if it is, the travelling suit has to be constantly put on at meal time. In short, this outfit is cheap, light to carry, light in use.

Hip boots, if punctured, are more easily 264 


\section{With What to Get Them}

patched and mended, require no care to dry and keep in order, look well, and last longer. One sees at times a "guy" dressed up in full regalia from tip to toe, like a knight in armor, so that the "natives" wonder if the thing is not a "Coney Island barker."

In fishing from a boat in the rain, the best covering is the duck-hunter's rain shirt, which is tight Rain Shirts to the neck and sleeves, and long enough to cover the legs; there is nothing more miserable than to sit still in pouring rain without proper covering.

For Southern fishing in Florida, Texas, and other warm sections, conditions are entirely the reverse, there being little or no rain, but much sun and hot weather. Everybody knows that white, thin material is cool and comfortable, and the main object is to be provided with a light, broadbrimmed head-covering that will not Southern blow away. A useful article to be pro-
Fishing

vided with is a mosquito shield for the head. They are cheap and can be folded compactly, and will be found most serviceable both night and day. At certain seasons some localities are infested with many species of abominable insects which make life burdensome.

The best head covering for hot climates is the "fisherman's phantom hat," made of a very light fabric, which can be folded and carried in the pocket without inconvenience. The sweat band is adjustable and will fit any sized head. It is suitable for ladies' or gentlemen's wear. 


\section{Fish and Fishing}

\section{SUNDRIES}

I might under this heading fill a chapter, if not a volume, as, taking the term in its broadest sense, fishing "sundries" might be made to embrace the entire contents of a tackle shop. But I will briefly refer to a number of necessary articles, useful to the angler and liable to be overlooked.

There are a few tools of inestimable value to the angler, which can be got small, compact, and easily carried in the inside pocket. First and foreRools most useful when you get to a barbmost is a pair of fine steel cutting pliers, wire fence that is impassable (it frequently happens to fat men). Pliers come in handy, should the hook accidentally fasten on the flesh, either of face or hands; such a thing happens in casting, though not often. Don't attempt to work the barb back, which is a painful and dangerous operation, but simply cut the point and barb off with the pliers, then the hook comes out easily. I once had to cut quite a hole in my first finger with the point of a pair of scissors, entailing the loss of blood that pliers would have saved in extracting the hook. In addition to the "cutting pliers" a pair of round and flat-nose pliers come in handy. Another valuable tool is a file for hooks Angler's and other things. The fishing knife is
Knife an indispensable addition to a satisfactory outfit for the angler. A proper knife should have a good stout blade, scissors, sćrew driver, 


\section{With What to Get Them}

and disgorgers. If they cannot be had in a combination article, they are necessary as separate pieces. The scissors are needed for fly-tying and gut-mending, the screw driver for reels, etc. The Bait-Angler's
Kit live-bait angler requires many more

odd things than the fly fishermanhis collection contains minnow pails, frog cans, bait boxes, dip nets and baskets. All these are now made foldable. To the ingenious inventors all anglers should be ever grateful and encourage such enterprise by purchasing their devices, whether they are required or not; they will come in handy at times. Being water-

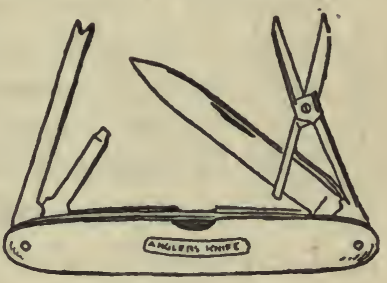

Angler's knife.

tight and weather-proof they do not spoil with age and can be washed clean and kept odorless.

Bulky fly books are a nuisance to carry, with a possible chance of dropping out of the pocket and floating away. A careful selection of the flies for the day's use can easily be made and placed in the small round boxes, sold for that purFly Boxes pose. As stated elsewhere, I attach
and Hooks a selection of flies to half a dozen leaders and take only those along, in a flat box with damp felt or blotting paper between the leaders to avoid entangling, and they are ready at all times to change in a "jiffy."

On the market there are a host of leader boxes, 


\section{Fish and Fishing}

but the neatest and most serviceable is the one shown in the cut, designed to hold eyed flies in centre box and casting lines surrounding it. One dealer has a neat, cheap useful X-ray tackle book to hold little things-swivels, links, small sinkers, etc., where you can see them at a glance through a transparent face. It is just the thing to take along for the day, for flies and leaders.

All-round anglers require a gaff with two handles, long and short; ciaff and Net each may be the gaff hook. A correct gaff hook should be perfectly straight up in the point; an incorrect hook

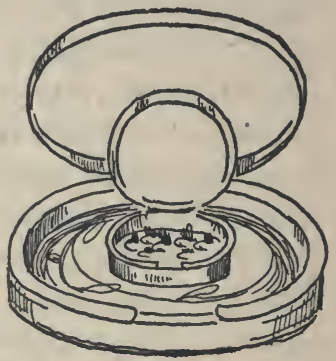

Saftey fly and cast box. has the point bent out or is provided with a barb. Such gaffs tear great holes in the fish and hold no better.

If the angler wants only one net he should have a long and short handle to fit. I have two nets, large and small, both folders; the small one with fine mesh, at times useful to catch bait, and the larger mesh for big fish-pickerel, small pike,

- ouananiche, large trout, and large bass.

A net, while troublesome and always in the Net Fasteners way, is indispensable in all kinds of to the coat or belt by a long rubber ring that will stretch as far as the hand in reaching the fish. 


\section{With What to Get Them}

The rubber can be hooked by means of a "pin carrier," easy to detach. There are various pins sold; the one in the shape of a safety pin, with a hook for the handle ring, is safe and reliable. Large nets with long handles can be hung from the shoulders, down the back (handle downward), and fastened to the creel strap on a hook, but so placed as to be instantly within reach. Those who won't carry a net lose many big fish. The regulation willow creel in shape is as perfect as can be. When bought new, it is best Stained to stain the creel either
Creels a dark blue, green, or brown. Time tones it down a lovely color, and it never looks dirty. After a few days' use the natural willow loses its cleanly look, and soon shows dirt and blood marks. Another advantage of a dark-colored creel is

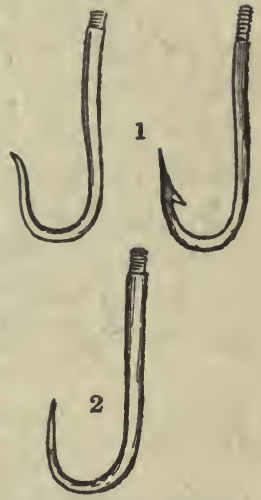

1. Incorrect form of gaffs. 2. Correct form of gaff. that it harmonizes with the clothes, and is not seen easily by fish. Any light-colored article is easily seen through the water. From the first the strap should be adjusted so as to fit the body snug. If it does not, when full of fish, it wobbles around and feels twice as heavy to carry. The folding canvas creels I don't like; fish cannot be kept fresh, for they become heated for lack of air and the creels soon become dirty, and have unpleasant odors. 


\section{Fish and Fishing}

Of tackle boxes there are no end, and the angler can choose from the variety those suiting his fancy. The same can be said of hook and fly books; every one has some good points, but as in everything else, the simplest are best. Careless Tackle anglers soon get the boxes and hooks in Tackle tangled confusion anyhow, after a time
Boxes accumulating a vast amount of needless things that are of service only on rare occasions. The best place to put them is in far corners, out of the way, and those things constantly required should be placed most convenient to get at.

For the angler who smokes, a pipe is the only comfort on the stream.' A turn-down brier is the article. Though an inveterate smoker, I rarely indulge while wading. I forget to puff, so it goes out. To light a pipe in the wind, Anglers pouch and filling up, in addition to the trouble of lighting the pipe, is hardly worth the temporary comfort. The serene delight, when sitting down in a shady nook after lunch with a pipe, is perfectly ideal. I once dropped my pipe in swift water, watched it float beautifully away, and turning aside in disgust, caught sight of another pipe floating toward me which I grabbed. quickly and found it to be much better and more expensive than the one I lost. The incident made me hope mine would likewise cheer some brother down stream. The best pouch is the screw folding-top article, made of rubber; in closing up it instantly becomes practically air- 


\section{With What to Get Them}

tight, and lies flat and snug in the pocket. The best match is what is called "Blazers." They are wind-proof, always strike (if dry), and they should be kept dry in the upper inside pocket.

The proper spring balance for weighing fish has

Hook made to spring round balance when not

in use

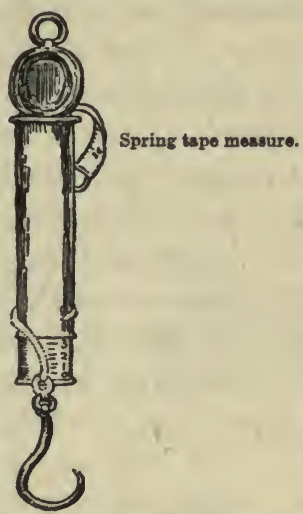

Author's suggestion for combination spring balance, and yard tape measure.

yet to be made. Those now offered are dangerous things to carry. The balance should be made so that the hook can fit

To Weigh and Measure Fish out of the way of hooking fast in the pockets and elsewhere. My idea of a good one is a combination affair of balance and tape measure of one yard to spring from the top, and the hook so made as to fit safely round the side. Till such is made, a small spring tape measure is useful to actually prove that a fish is as big as it really is. Nobody believes an angler's estimate as to size 271 


\section{Fish and Fishing}

without seeing it measured. A flat rule measures about an inch short on a curved fish. To measure a fish fair and.true the tape should be placed on the tip of the snout to the middle of the tail, not either of the tail tips.

A useful little device, furnished by Wm. Mills \& Sons, is a "line releaser." The beginner, especially, will find it a mighty good investment. The "Line casts of flies hanging on over"Line fished streams, tell the tale of the need of such a device. The "releaser" is inserted on the tip of the

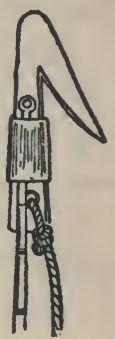

Line releaser. rod, under the rubber band, and the rod raised for the cutter to straddle the twig; then withdraw the rod and a sharp pull on the string cuts the twig, and saves the flies and leader.

Another good article for bottom-bait anglers is the "clearing ring." The hook too frequently becomes fast on rocks or snags at the Clearing bottom. The ring
Rings is run down the line to the obstruction and ' its weight detaches the hook. A hand line is fastened to the ring to draw it up. If the

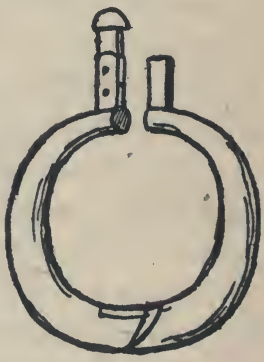

Clearing ring. hook is firmly fastened the ring can be raised a few feet by the cord and allowed to drop suddenly to clear the hook. This same device is as ser- 


\section{With What to Get Them}

viceable in fly-fishing when the hook sometimes becomes fastened on a rock or log. The ring easily releases it.

\section{WOMEN WHO FISH}

The women who fish are plenty, the women who wade are few. Yet fly-casting is an art more suited to women than any other mode of fishing; Fly=Casting active play for the mind, poetical as Suited to Women well as artistic pastime, and cleanly, as well as the least cruel. The most sensitive nerves would hardly balk at unhooking a little artificial, feathery fly from the lips, most often outside the lips, of a trout. There is no wriggling live bait to handle, and no digging down the fish's gorge to extract the hook. The daintiest methods are pursued that should entice many women to the streams. The trout has no spines to wound the fingers in handling, and however big, it will not bite. With all these advantages in woman's favor, the day will come, I fear, when laws will be passed excluding all men from taking brook trout, and reserving them entirely for the women. Her most vexing problem in wading is that of dress-how she looks in and after leaving the water. The difficulty is easily solved by wearing ample divided skirts of very Proper soft, woolly material, that will easily tuck
Dress inside the upper part of the waders. In so doing they need not wade in deeper water than two feet. After leaving the water the ample folds 


\section{Fish and Fishing}

can be let down in the usual way. Some will, perhaps, prefer to enter the water in high boots and duxbak skirt, letting it get wet as deep as they choose to wade. In brooks and small rivers it is never necessary to wade deep, so that but a few inches of a short skirt need be wetter. Be the skirts what they choose, similar clothing should be used to that mentioned for men's outfit. The jacket made to go with the duxbak skirt would no doubt be a wonder to any woman, with its twelve pockets of all sizes, inside and out, like hotel labels stuck on a returned European trunk, but the pockets are handy nevertheless. In the choice of headgear I do not presume to advise, but meekly suggest that any light-weight felt, without feathers or other flimflams, would be agreeable to most male anglers on the stream. The duxbak hat for women goes nicely to match the suit, which is a soft, light-green color, and rain-proof.

Tackle for women is exactly the same as that used for men, except that every item should be lighter. The rod should be four and a half ounces, Tackle very light line and reel, small-sized creel, and net. If the fair angler is a novice she should have a male companion, patient, attentive, and all-wise in the mysteries of the art, to coach her upon every point to make, and every move taken. She will soon become an adept if she is willing to act upon advice given. Should a fish take the fly, she must simply raise the rod tip, and keep it there, letting the fish do the work by playing around till thoroughly worn out, then 


\section{With What to Get Them}

she should quickly reel in till the fish is near enough to place the net beneath it, swooping it upward Way to Fish and carrying it to the river side on dry for Trout

land, there to extract the hook and plop the fish through the hole in the creel, where it is safe. Take no notice of its kicking; it only wants to get back to the water, which, of course, is not the purpose of fishing. The first success will fire the fair angler to further deeds.

In angling from a boat, either trolling or stillfishing with bait, dress counts for little; it can be anything to suit. In nine cases out of ten she will require an escort to bait her hooks and take off the fish from the hooks. I have known women do such things themselves, and enjoy it merrily. I have seen one land a good, big bass, though it broke the rod. 'She held on like grim death till the monster was boated; at the same time I wrestled with a big pike which seemed determined to stay right under the boat. But women have invaded the fields of larger game, tackling alone and Larger
Game sea-bass. Record fish have been taken by them weighing over two hundred and fifty pounds. The plucky holder of the record fish is a woman from Kentucky, a State made famous by its fair daughters.

Angling by women is as yet in its infancy. When they do take it up as a serious diversion or recreation I predict that most States will have to stock the streams much more thoroughly than they do at the present time. 


\section{CHAPTER IX}

\section{How to Play and How to Land Them}

\section{WAY TO HANDLE ROD}

The playing and landing of fishes are casually described under the heading of the game fish treated, but a few general rules that will apply to all fish are important. The experienced expert may skip this chapter, but the youthful tyro will find this part of the angler's art to be most valuable if correctly done, extremely vexing if done ignorantly. First, in playing a hooked fish three rules must be followed-a taut line, rod always upTaut Line right, the reel running free. Under these conditions, a fish, however large, cannot unhook itself, assuming the tackle is not defective. The play of the bending rod tip keeps the game in perfect control; the reel should have a restraining click but it should not be too hard, and the line ought not to be touched or manipulated by the hands, but by the reel handle instead. Nearly always the bass, ouananiche, numerous trouts, and the unspotted mascalonge, as soon as they feel the prick of the barb, shoot above the surface first. Immediately they do, the tip being 


\section{How to Play and How to Land Them}

up, it should be then slightly lowered and raised again as they get back to water, when they invariably surge to the bottom and run along, or stop there and jigger, that is, shake their heads back and forth, or roll over and over. Finding no relief and that they are still restrained by the line, they may make a running surge away or perhaps back to the angler; he should then reel, or give, as the case needs. All this time, the bending tip is doing the work of playing and tir-

Let the

Fish Work ing the fish, this being kept up until it shows a willingness to come to the surface, showing the whole white, or underside, of the body, which proves its surrender; or it may allow itself to be worked with only its head above the surface and body covered. At that stage of the game the fish, if possible, should be worked along with the flow of water, not against it, for two reasons: one is that the angler works easier down stream and has a better footing for moving rapidly; also, the fish is more quickly subdued by reason of losing its breath with the water, instead of gaining breath, against it. Cool, determined action is required. Slow deliberate work is better than a hurried desire to land the fish for fear of its loss.

From the moment the fish strikes the lure, be it a fly or bait, the rod tip must at once be raised as near perpendicular as can be. In that position it should stay till the fish is on shore or in the net.

Some anglers prefer to manipulate the reel handle with the left hand, others with the right. 


\section{Fish and Fishing}

I always reel in with my right hand, holding the rod with my left; this, I am aware, requires a quick change from right hand to left to hold the rod at the strike, but I gain in the extra strength and delicacy by using the right hand.

In boat-fishing, either with the fly or bait, the rod is not so easy to work when seated as it is in standing up, and to play a fish properly, the butt should rest solidly against the body. Sit perfectly still in the middle of the seat or chair, with feet firmly planted and knees well out of the way of action. Keep Cool Don't run excitedly around the boat, following the quarry in its tantrums. Permit the oarsman to keep the boat from weeds and away from the fish. As in river fishing, allow the rod tip to do the work and the fish to make the fight. All there is in it is just to.keep the line tight, rod up and hand on the reel. It is a revelation how much the fish does, how little the angler needs to do, if the right way is purşued. Never have a long line hanging down from the rod and reel to get tangled up at the bottom of the boat, or wound round the feet. That method is only proper when the rod and reel are not in use, viz.: hand-line fishing. Every inch of line should run directly from the reel through the guides of the rod, the fish unreeling, the handle reeling in. If a fish gets fast to a rock, Entangled $\log$, or weeds, in river fishing, keep a
Fish tight line and slowly walk round to another point and lower the tip a little, to give an opportunity for it to make a new start; if it does 278 
How to Play and How to Land Them

not, go back to the same spot again, giving a little tip and raise it with a little extra pressure. It may go; if it does not, tighten the line and see if a waiting game is any good: If it does not move, the line is no doubt fast and the fish gone with part of the leader; a slight whip movement must be tried to.loosen the rest of the line.

The remarkable variety of ways by which different kinds of fish resist capture is endless. In the larger kinds of marine game fish, their great bulk, in a measure, stops them from using deHow Fish vices so common in smaller game fish Resist the Net

like the bass, trout, salmon, ouananiche or even the mascalonge. The last I have known to wind itself in the line half a dozen times by rolling over and over on the surface, then to slap the lure, hanging from its jaws, viciously with its tail, successfully breaking the line. It is a common practice of the pike to come up like a lamb only to make a sudden and violent lunge just as it is being netted, when the line is reeled in tight. On one occasion, after playing a large rainbow trout for some time, I had it, as I thought, "just as good as landed," with its nose in the net, but with a sudden bound it shot right between my legs, snapping the rod to shivers because of the short line. I have had a decided opinion for many years that a game fish is not safe till it is rapped on the head and quiet. Few trout fishermen will bother with a net, but they lose large fish if the water side is not suitable for beaching them. Bass fishermen often trust 


\section{Fish and Fishing}

to the large hooks and lift them. Ouananiche cannot be taken from the water without a net. Mascalonge as well as salmon are nearly always gaffed, or the mascalonge as well as pike are often shot through the head with a bullet from a revolver. This I do not approve, being a step from angling into hunting. In river fishing, or wading rapid streams, if the sides are sloping, pebbly shores, it is safer to lead the fish and pull it gradually up the side from the water. If that is not possible, the net only is available. After To Use the fish is thoroughly tired, reel up till the leader touches the tip; then with the right hand hold the net, holding the rod high above the head with the left hand; work the fish close in, nose facing the net, which is placed well under the water; when the greater part of the fish is above the net, scoop it up, at once releasing the line strain. To extract the hook, while holding net and rod, is difficult while standing in the water, but with a little patience it can be done. If possible, step on shore, for it saves time, as everything can be laid down on dry land, and the work done more quickly.

When fly-fishing, the flies are sure to get entangled in the net and extra trouble made to get the kicking fish in the basket. Further details how to use the net are given in "Landing Trout." The same method is pursued with all other fish. To gaff any large-sized fish-pike, mascalonge, or salmon-it should never be attempted in very shallow water, if it can be avoided. The gaffer 
How to Play and How to Land Them

should always keep a little below where he expects the fish to be brought toward him, and wherever he places himself he should remain stationary, in a stooping position, with the gaff ready for action. Should he move about the fish will probably get sight of him, and if it does the chances are it will make a run away

Gaffing Salmon and Mascalonge and will not allow itself to be brought within reach till exhausted.

What the angler has to do is to wait till the fish is quiet, then get its nose above water, and run it to the gaffer, who will seize the opportunity, give one clip and all is over. On no account should he attempt to put the gaff in, should the fish commence to struggle, but wait patiently till it is quiet again. To gaff a fish, as it should be done, requires great nerve and a great deal of practice. An experienced gaffer will bide his time and gaff the fish somewhere below the back fin, which will balance it as nearly as possible and prevent the flesh being torn in the struggle.

To gaff a fish in deep, rapid water is a more difficult thing than it appears. For the angler to gaff his own fish requires great skill and dexterity, as the risk incurred with the line In Deep being wound up so short to enable him
Water to reach the fish makes it very likely that the rod will get smashed. To gaff a fish while in a boat is the easiest. The only thing is to take care the fish is quiet; then drive it in the right spot, always, if possible, near the middle of the body, so that in lifting into the boat, its 


\section{Fish and Fishing}

struggles are merely side to side. Never try to gaff a fish before it is completely tired and doIn a Boat cile; let it run time and again till it is used to the sight of the angler. If the strike is short and only makes a wound in the side with insufficient hold, let it go, keeping a firm grip on the handle. When brought back again, take true aim and strike hard.

The gaff handle should be at least three feet long and the point perfectly straight and very sharp. The strike should be made in one single drive home, sufficient, if possible, to stun the fish for the time being. With the same action of the drive the fish should be lifted right into the boat Strike or on shore; it should not remain in the
water an instant after the gaff pierces the flesh. If it does, the fish kicks so vigorously that some difficulty ensues in getting it out, especially if it sinks a little, giving an' opportunity to take advantage of the water force, and to struggle till it wriggles off the hook; slack the line so soon as the gaff is securely placed. 


\section{CHAPTER X}

\section{The Right Way to Keep Fish Fresh}

\section{IN THE CREEL}

Most fish when first taken from the water are very beautiful. Their plump, cool, shining bodies are solid, yet springy. How different they look after the day's fishing is done, and they have been perhaps, carried several miles exposed to the burnning sun. The creel is opened on arrival at the hotel to find the fish dried stiff, so that they could be stood upright like a burnt stick. The careful angler does better. On the way down the stream he looks out for dock plant, plucking enough of the large, luxuriant leaves to line the creel and keep the fish in their natural beauty. Neither grass nor ferns make a good lining for the creel, as both leave ugly print marks on trout, and neither is so good to keep the fish fresh or free from flies. If the creel is lined with large dock leaves the fish (especially small ones), lie snugly together, Lining the their cool bodies being unmarked; they also keep fresh, because the air cannot penetrate between them, and for that reason they keep their color. Opportunity is given for 283 


\section{Fish and Fishing}

fresh air to enter from the top, and the fish being a solid mass at the bottom are perfectly fresh and bright at the end of the fishing. When that is over and no other fish are to be put in the basket, another layer of dock leaves should be laid on top to keep the sun and dust from the fish on the return tramp or ride home. All small fish, especially perch, bass, pickerel, and trout, soon dry up when taken from the water. The slimy substance on trout soon becomes absorbed in the skin, the tail and fins dry as a stick, and their whole appearance not half so pleasing as when first caught.

Every day the creel should be well washed; if it is not, flies will blow in the crevices of the wickerwork, and in a few days maggots appear before the angler is aware of it. Never leave small fish in the creel overnight, because if Wash the left on the ground, ants and other in-
Creel sects swarm around, get inside the fish and so rot them. Some anglers make a bed of ferns do for the entire trip of several weeks, with possibly a few stray little fish lost in the bed, so that in a few days the creel is a foul, ill-smelling thing, not fit to have in a room; much less is it fit to have fresh-caught trout laid in so vile a place.

If the angler makes a full day's sport, he should at lunch time take the creel from his shoulder and place it in the cool water, two inches deep, of some running spring, after he has quenched his thirst. Let it lie there, shaded by trees or plants, while he lunches. When through, take the creel out, and let it drip well before resuming 


\section{Right Way to Keep Fish Fresh}

sport. This cool bath will not only freshen the fish but revive the leaves, and so give sufficient moisture to the fish for the remainder of the journey.

While fishing in a boat, on a lake or pond, it is better to have a creel with you. The sloppy, dirty method of letting the catch lie at the bottom of the boat, flopping around, dirtyHave a Creel ing clothing and boat, moreover
in Boat drying and rotting in the sun, is a thing to be avoided. The creel can be lined with some lily leaves, which prevent the heat from the bottom of the boat getting to the fish. The creel should be kept well shaded from the sun, conveniently near the angler, so that it is possible to unhook and drop the fresh fish where they may be kept together. A covered box is not so good, though better than nothing. There is less chance for the air to get in a box, to keep them fresh and moist. Some anglers have a "fish string," bought at the tackle shops. They string the fish through the gills, hanging them dangling in the water. This method has nothing to recommend it. Those fish in the water change color, those out dry up, and the trouble of stringing live fish, especially bass, is annoying. In fact the "fish string" is a snare, especially to carry any distance; it is neither clean nor convenient.

\section{ICING THEM}

To carry very large fish not convenient to put in a creel, from five to twenty pounds' in weight, 


\section{Fish and Fishing}

like salmon and mascalonge, the best thing I know is a "carry-all," which is simple, easy and light. "Carry=All" Scotch anglers have a woven basket with two handles, to be carried over the shoulders with a stout stick. The "usk" basket will carry half a dozen salmon or pike comfortably. A "carry-all" need only be a double piece of rubber canvas or plain canvas matting, with two straps attached, or the shoulder

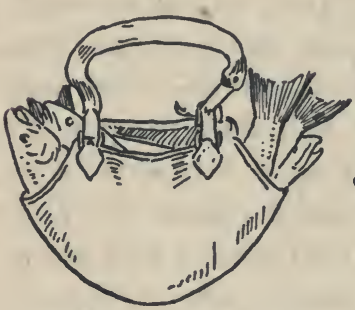

Double piece of water-proof canvas held together by straps for the shoulder.

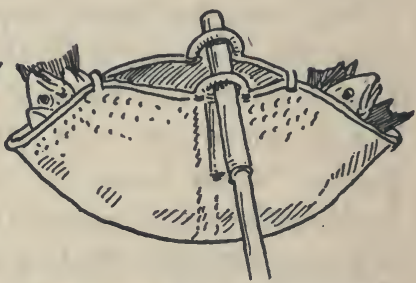

Rush woven basket, to be carried on the shoulders by means of stick or rod-butt.

Baskets for large fish.

strap passed through metal rings at the top, the larger fish showing the heads and tails at the sides. To be satisfactory they should be made strong, if they are to hold heavy fish. Such bags as these should, if possible, be lined with leaves to keep the fish moist and their skin bright and fresh. The dock leaf is best beKeeping cause of its large size and smooth sur-
Moist face; in boat-fishing, pike and mascalonge can be slung in the "carry-all," from one of the boat seats. In salmon fishing one rarely goes unaccompanied by a guide or two, and 286 


\section{Right Way to Keep Fish Fresh}

they use their own methods of taking care of the fish, usually placing them carefully at the bottom of the canoe and covering them over from the sun's rays. It is often a difficult problem to transport large fish, like trout, pike, or salmon. Half a dozen ten-pound fish are quite enough for a tired angler to lug, even a short distance. If nothing better can be done, a good, stout, heavy stick may be slung across the shoulders, with the fish hung up by the gills and balanced front and back evenly.

Many anglers often land a big fish some days before they desire to return home, and they want to save such a trophy for a city friend. I often pick out of the day's catch a brace of trout to keep for my return home. I do not believe fish keep better after being "gutted" or opened and the insides taken out. The best way to preserve salmon, trout, pike, and bass (the two latter fish keep longer fresh) is to take the best care not to bruise or handle them, and not even wash them, but simply take them from the creel, handling them " gingerly," only by the gill covers. They should Icing Fish then be placed on a large cake of ice, in the ice-house, so situated that ice will be above as well as below them. I usually ask to have a block taken right out, leaving a space ample for the fish I expect to keep, and then fill up the space entirely with sawdust, which can be removed every time additional fish are put there. The fish are better if not put together; that is, have sawdust divide the fish, for the reason that each fish will have cold all over it. If an ice-house is not 


\section{Fish and Fishing}

available, and a refrigerator is only at service, then lay the fish flat upon the ice, and cover them over with clean paper, which will soon absorb moisture and retain it. In an ice-house, with ample sawdust, trout may be kept for some time, even for weeks, sweet and fresh. It is only safe for a few days if the trout is kept in the refrigerator. Without the aid of ice, it should be wrapped in damp, brown paper, or some woollen cloth, then placed in cold, damp earth or wet, cold grass where the temperature is as cold as possible. Be careful to have the fish so well covered that air cannot penetrate. In that condition it will keep forty-eight hours. I Sawdust have kept trout for two days covered well with sawdust, then wrapped in three layers of paper, all thoroughly damp, but not wet, then laid in a little cold, running spring, so that the water just ran by and touched the paper. Such a place must be well shaded, without the sun getting at it. Two and a half days after, having travelled in hot cars fifty miles, they were in fair condition. All fresh-water fish keep longer. and fresher if left entire, without being slit. It is the greatest mistake to open them and remove the gills, for immediately the head as well as the inside begins to fester and rot. The skin is a natural protection to the flesh, which, if left bare and open to the atmosphere, soon turns blue and soft. If the gills are well pressed down to exclude the air, and the mouth kept closed, the fish will keep much better than if the gills are cut away. 


\section{Right Way to Keep Fish Fresh}

\section{PACKING THEM}

It is the reverse with fish caught in salt water, especially those of a large size. A salt-water fish, say a large, striped bass, often has its stomach chock-full of partly digested food,

Packing Marine Fish which, at the death of the fish immediately begins to rot, and, if not removed, turns the flesh blue and makes it rancid. After making a slit from the vent nearly to the gills, do not split open the chest bone, but endeavor to remove the gills separately. Leave the blood sac, along the backbone, entire; though it turns black and clogs in a solid mass, it assists in keeping the flesh crisp and sweet. A fish heavy with roe should not be cut open, but kept and packed entire. Sea fish are more salty, both in flesh and skin, than fresh-water fish, therefore will keep longer in good condition; though all fish, fresh or salt, lose their rich flavor the longer they are kept. Bottom-feeding fish keep much longer than game fish that feed on the surface. All fish are better if not handled much or moved often. All fish, both fresh and salt water, if packed and shipped in cracked ice, and so kept from the time they are killed, keep.perfectly fresh and cold. If packed in

Bottom Fish Keep Longer a solid box, the ice (with proper care that the box is not exposed to the rays of the sun, or placed in a hot, close room or car), should last at least twenty-four hours; longer if placed where cold air is about it. 


\section{Fish and Fishing}

To pack fresh-water fish without ice they should be rolled repeatedly in wet paper or wet cloth, woollen preferred. They should then be wrapped all together in large rhubarb, dock, or any large fresh leaves, and thoroughly wetted. They should then be embedded in wet sawdust contained in a solid wooden box; or if in a wicker basket, it should be lined with stout dry paper, which should keep the contents air-tight, and so retain the moisture and cold. In this way I have kept game fish (fresh water) a day and a night of travel on the cars as ordinary baggage, without extra attention or care; grass, hay, or straw are the worst things to pack fish in, as they sweat and get hotter and hotter.

Long moss, got from boggy and damp places' in woods, is excellent to pack fish, but it should not be too wet; it makes good padding in place of sawdust. Water-cress is another good substitute for sawdust, because the stems Water=Cress retain the cold moisture, and stay
and Moss perfectly fresh for a considerable time if kept cool. In fact, I always line my creel with water-cress when taking trout home. At the end of a day's railway journey the cress is just as crisp as when first cut, therefore the fish are kept cool and moist. If trout are completely covered with water-cress, then wrapped well in newspapers, they can be stitched up in a bundle of coarse bagging, and will stand a twenty-four-hour railway journey.

Salmon require more care, and I know of noth- 


\section{Right Way to Keep Fish Fresh}

ing better than a solid box, well put together, of inch material and filled with cracked ice, with Paper and the fish embedded. On the box there Packing should be a tag marked "perishable goods." With proper care it should arrive in New York City from Canada or Nova Scotia in fresh condition.

Salmon, pike, and mascalonge travel better and arrive fresher if not cut open, and they are also better if packed immediately after they are killed, or as soon after as possible. When they are delivered they should be at once put on ice, and kept there till the time comes for dressing and cooking.

If fish are cleaned and scaled before shipping they lose their solidity and taste more insipid, and if long on the journey actually become rancid and unfit for eating purposes. 


\section{CHAPTER XI}

\section{How to Cook Them}

\section{CLEANING FISH}

Anglers should endeavor to keep their quarry moist from the time it leaves the water till it is to be cleaned, and not until after the gills and insides are removed should it be washed. Always scale a fish before the fins are cut, or the inside slit

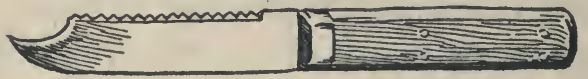

Fish knife and scaler.

open, otherwise scaling is not done so quickly or so neatly. There are various fish scalers sold in the tackle shops, and that shown in cut is Scaling among the best. It is neat and compact,
Fish the sharp point being useful, though, to my mind, such a tool should close. If such a tool be not handy, use a blunt knife, near the haft. To scale a fish well, grasp the tail in the left hand, or pin the tail down on a board, scaling hard and quick as the scales slip out of their sockets easier by so doing. Scrape around all parts on both 


\section{How to Cook Them}

sides, then cut off the fins with a sharp knife or shears, and wipe the fish clean and dry with a cloth. The gills should then be-cut from the lower jaw and back of the head, a slit being made from the head along the lower body to the vent. The gills being pulled will at the same time draw the insides away, and if done with care, a perfectly clean inside is the result. In most fish

Washing and Cleaning Fish

(if fresh) the blood is encased in a thin skin close to the backbone and can be pulled away entire. A fish so treated can and should be prepared without the use of water. After being cleaned and scaled it should be well washed in two waters, to thoroughly divest it of all slime and blood. If it is a fresh-water fish it can be placed in a vessel of salt and water to soak for half an hour; if they are coarse fish, caught in quiet, stagnant pools (such as carp, catfish, perch, eels, and pickerel), an hour's soak is better. Afterward they should be taken out of the bath, dried with a clean cloth, and they are ready for cooking. To skin eels, catfish, perch, etc., a slit is made a short distance To Skin Fish down the back from the head; then take a pinch of salt or sand between the fingers, to stop the skin from slipping, pull steadily toward the lower part of the fish on one side and then on the other. This should be done before the belly is cut open, or else it tears away the shoulder bone. When the skin is pulled down to the lower under-fin, pull from the other side; then take both sides together, and it will tear off 


\section{Fish and Fishing}

from the tail in one piece. This refers to the catfish, perch, and eels. After a good grip is secured the skin comes off entire from the body of an eel without trouble.

To fillet a fluke or flounder, before cleaning get a good sharp knife with a point, and cut along the backbone of the fish from head to tail; then shave it close to the bone, taking the fillet in the left hand as it leaves the fish; begin likewise on the other side and repeat the same. Turn over To Fillet the fish, taking away two more fillets, making four pieces of boneless fish; nothing but the skeleton remains. All the bones being perfectly flat, the flesh is easily cut away, leaving the bone absolutely bare of flesh. Flat fish are more easily done, but all fish can be so treated by this method and made boneless.

All fish for the pan should be scaled, head and fins taken off, then cut down the back clear through the bone; then open-up the fish flat and take away the inside (it is not so good to open it from To Fry Fish the belly); wash well and dry with a cloth. For broiling it should be treated in the same manner. For baking either fresh or salt water fish, scale and remove the gills; leave the head on, but remove the inside; wash, and then dry.

To prepare a large fish for boiling, scale and Boiling Fish then clean it, cut off the fins, leaving the head and tail intact. The fish should then be cut through the body in three parts, to allow its being placed in the kettle before 


\section{How to Cook Them}

being wrapped in the cloth. Take a piece of cord and wrap around the head, under and above the middle piece and around the tail piece so that the fish can be put together in its natural position on the dish after being cooked. Never sever the head from a fish, unless it is to be skinned, filleted or fried. Fish served at the table, headless and tailless, look queer and unnatural.

\section{COOKING FISH}

In cooking pan fish, both fresh-water and marine, some people prefer to dip them in bread crumbs or a batter of flour and eggs, or cracker crumbs and egg. In such a manner they may be either whole small fish, fillets or slices of large Frying fish. Either way they should have salt and pepper scattered on before being placed in the pan; some parsley, along with a few slices of green onion tops, gives it a relish. Serve the fish with a garniture of water-cress.

For baking trout, pike, striped bass, etc., scale the fish and remove the gills; leave the head on Baking Fish but remove the inside; wash, and then dry. Make a stuffing as follows: Beat two eggs, add four chopped oysters, two sliced and boned sardines, one cup of grated bread, some chopped onions, minced parsley, a little pounded mace, black pepper, allspice, and salt. Beat a piece.of butter in the stew pan, stir the whole dressing together over the fire till of the consistency of a thick bat- 


\section{Fish and Fishing}

ter. Fill the fish with the stuffing and sew it up; put slices of fat pork into small holes made through the skin of the sides and back. - Bake in a moderate oven, basting with plenty of butter, and serve garnished with pickled mushrooms, parsley, and anchovy sauce.

To broil fresh or salt water fish, split it from the back and clean it, rub over with oil or butter to keep the skin from sticking, and grease the broiler with salt pork. Have the fire hot and clear, a Broiling wood fire being best, and keep constantly turning till done. Place the fish on a hot dish, season well with salt and pepper and a lump of butter, then spread over it anchovy or tomato sauce, with a garniture of water-cress and sliced lemon.

A primitive and simple camp method is to take a good-sized fish, just out of the water, and without cleaning it, wrap it up in a wet paper and place it in the red-hot coals, testing now and then

\section{Camp Cooking} with a fork. When the fork goes through the fish easily, it is cooked. Twelve or fifteen minutes is long enough; then carefully remove the fish from the paper, leaving the skin adhering thereto; season it with butter, salt, and pepper, and serve it with cress.

Another way to bake a fish is to cover it (undrawn) with clay, two inches thick, and place it in the hottest part of the fire; the clay hardens almost instantly and the fish in its rough oven bakes through, retaining its juices. The clay is then poked out of the fire, cooled with a dash of 


\section{How to Cook Them}

water, and a sharp stroke separates it from the fish. The skin peels off with the clay, and it is then seasoned ready for serving. If clay is not at hand, wrap the fish evenly in thin buttered tissue paper and bury this in some wet, brown, wrapping paper; then bake same as in clay.

The easiest and quickest way of all to bake a Camp fish is to split it, cut off the head, tail and fins; then season, pin it to a board by wooden pegs and prop the whole up before a smart fire of hot coals.

\section{CUTTING AND SERVING FISH}

Few men understand how properly to clean and cut up fish, and fewer still know how to cut a fish when cooked for serving. A small fish when cooked should be slit down the back, the flesh stripped off in one piece from the back. With the left hand, take the head, lift it slowly (a fork holding down the lower half), and it will pull along with the backbone all the ribs from the flesh, leaving practically two filleted and boneless pieces ready to be eaten.

To carve or cut a large fish, it should first be slit down the back, then cut crosswise every two inches or so, and taken away from the backbone in pieces. When the first half is cut

Cutting Cooked Fish away, disjoint and lay aside the backbone, leaving the head and tail on the fish with the lower part; then cut it as before. Use a sharp knife for cleaning, a dull broad 


\section{Fish and Fishing}

fish knife for cutting when cooked. In my opinion fish are a delicious dish if cooked when fresh, no matter which way they are cooked, provided they are well cooked, for underdone fish are uneatable. If overdone, the flavor is gone, or it is too dry. Some people prefer fish served with all the skin removed. This can be done either before or after cooking. Skinning before is much the quickest way.

Sea fish require less salt, as a rule, than fresh fish. In camp salmon or other steaks can be broiled on a single broiler, not the clasp variety, as the fish in turning drop out on the coals. A flat piece of birch bark can be placed over the fish on the single broiler, when turning; it can be turned back on another piece, and so placed on the other side of the broiler.

There are two ways to tell if a fish is stale or fresh. First, if the eyes are bright and glassy, it is fresh; if sunken, dull, discolored, it is stale. Second, if the finger be pressed on Testing Fresh Fish the fleshy part and it is solid and elastic, the fish is fresh; if the pressure leaves a mark, it is stale. This applies to salt as well as to fresh water fish. 


\section{CHAPTER XII}

\section{Simple Hatchery for Trout}

\section{TROUT BREEDING}

Many trout anglers have private waters, either a stream or pond (big or little), where they can invite a few friends now and then to share their sport, so that at times they deplete their water of fish more than they desire. Some know, but the majority don't, that trout breeding can be carried on by them at a very moderate expenditure of time, trouble, and money.

When trout eggs are within a week or so of hatching they are called eyed ova, the eyes of the embryo fish being distinctly visible through the shell of the egg. Eyed ova are supplied by all the fish culturists and by the following, Where Eggs for brook trout: New England Trout Farm, Plympton, Mass., L. B. Hándy, Wareham, Mass.; Plymouth Rock Trout Co., Plymouth, Mass.; Paradise Brook Trout Co., Parkside, Pa.; for small-mouthed black bass, Henry W. Buman, New Preston, Conn.

Eggs may be sent to any distance (only buy those which are guaranteed to have been taken 


\section{Fish and Fishing}

from large fish), but the shorter the distance trout of any size have to travel the better.

To hatch the eggs, they may be placed on a gravelly shallow in the brook or stream, in a foot of water or less, and covered with a piece of fine wire netting. They should be ordered to be sent just at the point of hatching, so that they will hatch out in a couple of days.

The fry will look after themselves. Floods are a standing danger to this plan. Fry, unless bred in enormous quantities, are very little use in rivers which already contain feeders on fish, like eels, catfish, suckers, carp, pickerel, and perch. A stream, however small, which runs into a pond affords every convenience for hatching out the ova and rearing the fry. The pond should be cleared of other fish, and the outlet carefully Care of Fry guarded with very fine perforated zinc to prevent the escape of the fry. Some slight preparation is advisable in the stream. The simplest thing to do is merely to lay the eyed ova on a suitable shallow (where the water is four to eight inches in depth, and flows gently), cover them with fine-meshed wire netting, fixed a few inches above the surface of the water, and leave them. It is advisable to cover over the whole of the brook, from your trench to the pond, with netting, to save the fry from kingfishers, herons, etc.

But all streams are subject to floods, and the safest way to deal with the ova is to prepare a trench for them by the side of, and fed by the 300 


\section{Simple Hatchery for Trout}

water from, the stream. No more water than can pass through the pipe which feeds the trench can then find its way to the eggs. The ground plan of a stream pond and trench, Fig. 1, will show how very clearly. The inlet pipe $\mathbf{A}$ may be made of three-inch drain pipe. The trench $\mathrm{B}$ can be lined

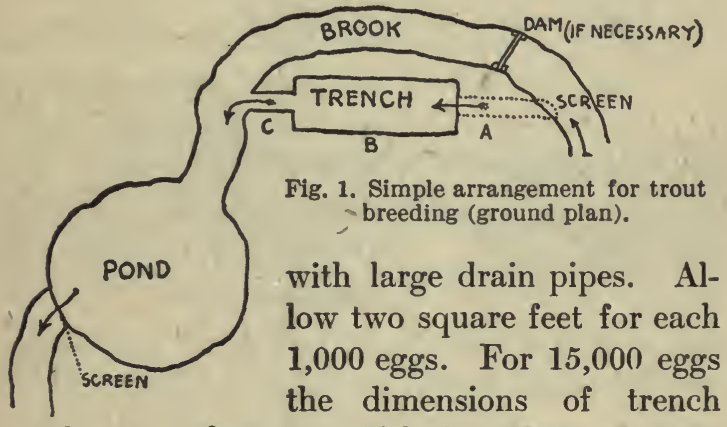
may be two feet in width by fifteen feet in length, or, better still, one foot by thirty feet. The outlet C should be about six Construction of Hatchery

inches wide and open to the air.

The bottom of the trench should be covered with three inches of clean stones, about an inch in diameter, among which the fry can hide themselves when first hatched. Put no screen or obstruction in the channel $\mathrm{C}$, but allow the fry to pass down to the brook, and from the brook to the pond, just when they think fit. A large piece of perforated zinc should be placed in the brook at the mouth of the inlet A to prevent the entrance of fish, rats, or rubbish; and if there is not sufficient fall in the 


\section{Fish and Fishing}

brook to cause the water to flow through the trench, a small dam may be required across the brook below A. This arrangement may be made by any laboring man for something under ten dollars. But of course where expense is no object, a considerable amount of money may be spent in stone work, settling pond, filter, etc. Fig. 2 shows the trench, inlet and outlet in sec-

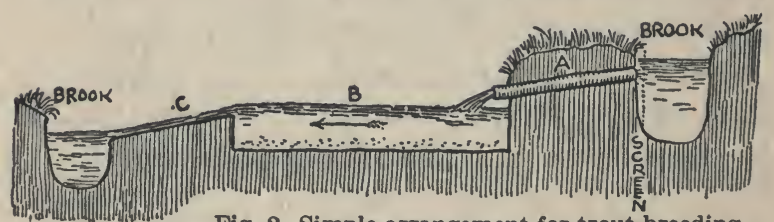

Fig. 2. Simple arrangement for trout breeding (section of fig. 1).

tions. With lakes, ponds, and rivers already containing brown trout, or other depredatory fish, unless trout of half a pound or upward can be purchased and turned in (a costly proceeding) the best plan is to thoroughly stock the Brooks tributary small brooks. Ninety per cent. or more of the fry placed in rivers containing numerous large trout, pickerel, perch, bass, etc., are eaten up. Besides putting in fish, great attention should be paid to making the streams suitable for trout, increasing the food supply, and plenty of shady places, large rocks for hiding, and weeds to induce insect growth.

The various proceedings necessary in trout breeding by professional and State hatcheries are as follows: When the trout are seen on the shallows, in October and November, they are netted 302 


\section{Simple Hatchery for Trout}

in small-meshed nets. Those from which the ova or milt run easily (ripe fish) are placed in a can of water, and the unripe remainder returned or left in store, or afloat, to mature. From the males a milky liquid will flow at almost the slightest handling, while from the females a touch will cause the appearance of a few eggs the size of small peas. To spawn the female, hold her tail in your left hand, head in the right hand, raise the head and hold the vent of the fish over an agateExtracting lined dish. If only the Ova one or two small fish are to be spawned, bend the tail back a little, causing the skin

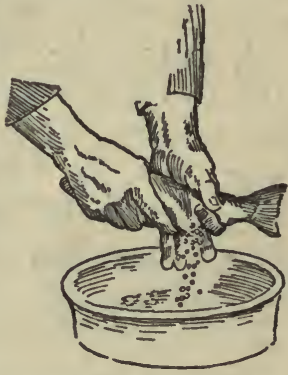

Position of the hands in stripping a female trout. on the belly to tighten, and the eggs will flow out. If the eggs do not flow freely, or any are left, pass the right hand downward over the belly, using little pressure until past the vitals. Next, quickly take a male fish, hold the abdomen against the eggs and gently press with the thumb and forefinger above, and just behind, the pecThe Milt toral fins. Have a towel in front of you during these operations and lay the fish on it, when not handling them, and if you cannot both hold and spawn the fish yourself, let an assistant hold the fish for you, and, in any case, wear a woollen or cloth glove on the left hand. To return to the eggs; after the ova are milted, 303 


\section{Fish and Fishing}

add a tumbler of water and gently stir the eggs and milt together. The eggs will shortly stick to the dish and together. Do not remove them until they have separated, which will be in from half to three-quarters of an hour, or a little more. Next put the dish under a jet of water, and let the water overflow and carry with it the effete milt. The eggs are now ready to be laid down, and all that is required is a constant flow of unpolluted water, about three inches in depth. Any dead eggs must be picked out every morning, and there must be nothing in the material of which the troughs are made (if the eggs are put in troughs) which will poison the water, or bear any fungoid growth likely to be communicated to the fish. The eggs may be placed in a long wooden trough (if wood is used it must be charred) out of which the water passes at one end through a very fine screen, or they may be laid down in gravel in a brook or backwater, of course being carefully guarded from water birds and other enemies; or they may be placed in an artificial trench, as shown in cut.

No two eggs should touch each other; any crowding should be avoided, and, if possible, the eggs should be kept in the dark. The current which passes over them should be gentle for it may wash the eggs away. But the slower the Quantity stream the shallower must be the water. Trout eggs can easily be hatched out in city water, more easily, indeed, than in the country, where sometimes the sediment in the water 304 


\section{Simple Hatchery for Trout}

is a constant source of trouble and loss. If the eggs get covered with sediment, the water in the trough must be added to night and morning, with a watering can, and the stream through the trough increased.

The best thing to do with the fry is to place them, at the end of the three weeks, in a pond in which there is plenty of food (first clearing it out of other fish), when they will feed themselves, and grow rapidly or slowly, according to the food supply.

If the natural food supply is not equal to the wants of the fry, a certain number of the little fish are bound to die. The fry at some hatcheries are fed on a paste (made in worm-like form, by being Feeding Fry squeezed through perforated zinc) or liver, pounded, and intimately mixed with the yolks of hard-boiled eggs (nine to each pound of meat) and passed through a wire sieve.

In some ponds there is sufficient natural food, and the fry do not require feeding. For more complete information on this subject the reader should consult Livingston Stone's "Domesticated Trout," which gives the "dry method" of trout propagation. The foregoing description refers to what is termed the "wet method," the only difference in the two being that the eggs and milt are taken in a dry spawning pan instead of one partly filled with water; and by the dry process one hundred per cent. of good salmon or trout eggs may be impregnated, while by the wet process, 


\section{Fish and Fishing}

with an inch or two of water in the spawning pan, only from sixty to seventy per cent. are impregnated.

Dry impregnation was discovered by Mr. V. P. Vrascki, a Russian fish culturist, in the year 1856. Numerous discoveries have since been made and nearly all modern fish culturists use the dry process.

The average production of trout eggs is from 300 to 1,500, depending upon the age and size of the fish. With water at fifty degrees Fahrenheit the eggs hatch in about fifty days. But with water about thirty-four degrees Fahrenheit, they will require over one hundred and fifty days. Impregnated eggs are amber-colored, and dead eggs are as white as chalk and must be picked out from the good eggs to prevent the spread of disease to the good eggs. 
M̄313039 


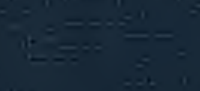

$$
\begin{aligned}
& 4 \text { - } 0 \text { a }
\end{aligned}
$$

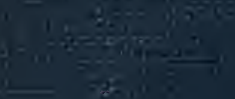

$\frac{1}{5+2}-28$ 5. 